\title{
Antimicrobial therapy for chronic bacterial prostatitis (Review)
}

\author{
Perletti G, Marras E, Wagenlehner FME, Magri V
}

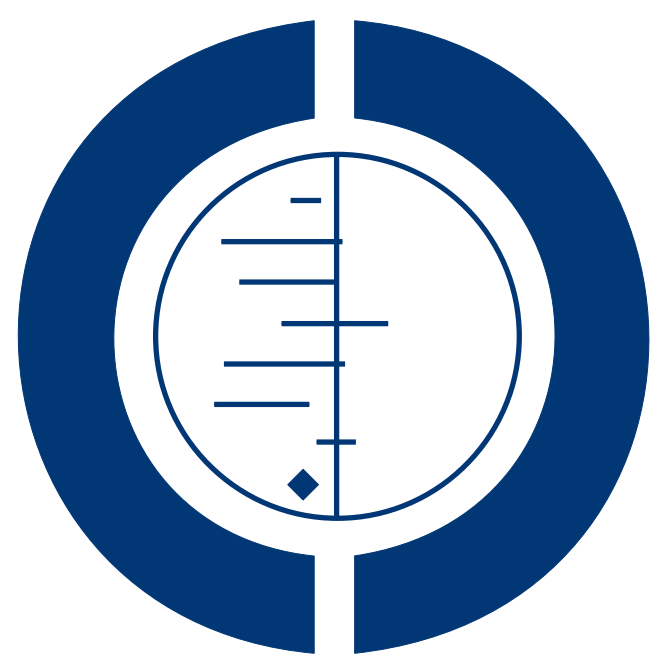

\section{THE COCHRANE COLLABORATION $^{\circledR}$}

This is a reprint of a Cochrane review, prepared and maintained by The Cochrane Collaboration and published in The Cochrane Library 2013, Issue 8

http://www.thecochranelibrary.com

\section{WILEY}


TABLE OF CONTENTS

HEADER . . . . . . . . . . . . . . . . . . . . . . . . . . . . . . . . . . . . . . . . . . . . .

ABSTRACT . . . . . . . . . . . . . . . . . . . . . . . . . . . . . . . . . . . . . . . . . . . . . . . . . . .

PLAIN LANGUAGE SUMMARY . . . . . . . . . . . . . . . . . . . . . . . . . . . . . . . . . . . . . . . . . . . . .

SUMMARY OF FINDINGS FOR THE MAIN COMPARISON ．．．．．．．． . . . . . . . . . . . . . . . 3

BACKGROUND . . . . . . . . . . . . . . . . . . . . . . . . . . . . . . . . . . . . . 5

OBJECTIVES . . . . . . . . . . . . . . . . . . . . . . . . . . . . . . . . . . . . . . . . . . . .

METHODS . . . . . . . . . . . . . . . . . . . . . . . . . . . . . . . . . . . . . . .

RESULTS . . . . . . . . . . . . . . . . . . . . . . . . . . . . . . . . . . . . . . . . . . . .

Figure 1. . . . . . . . . . . . . . . . . . . . . . . . . . . . . . . . . . . . . . . . . 11

Figure 2. . . . . . . . . . . . . . . . . . . . . . . . . . . . . . . . . . . . . . . .

Figure 3. . . . . . . . . . . . . . . . . . . . . . . . . . . . . . . . . . . . . . 13

ADDITIONAL SUMMARY OF FINDINGS . . . . . . . . . . . . . . . . . . . . . . . . . . . . . . .

DISCUSSION . . . . . . . . . . . . . . . . . . . . . . . . . . . . . . . . . . . . . . . . . . 27

AUTHORS' CONCLUSIONS . . . . . . . . . . . . . . . . . . . . . . . . . . . . . . . . . . . . . . .

ACKNOWLEDGEMENTS . . . . . . . . . . . . . . . . . . . . . . . . . . . . . . . . . . . . . .

REFERENCES . . . . . . . . . . . . . . . . . . . . . . . . . . . . . . . . . . . . . . . 30

CHARACTERISTICS OF STUDIES . . . . . . . . . . . . . . . . . . . . . . . . . . . . . . . . . . . . . . . .

DATA AND ANALYSES . . . . . . . . . . . . . . . . . . . . . . . . . . . . . . . . . . . . . . . . . . . 64

Analysis 1.1. Comparison 1 Different fluoroquinolones: levofloxacin versus ciprofloxacin, Outcome 1 Microbiological efficacy - pathogen eradication (fixed-effect model). . . . . . . . . . . . . . . . . . . . . . . . . . . .

Analysis 1.2. Comparison 1 Different fluoroquinolones: levofloxacin versus ciprofloxacin, Outcome 2 Microbiological efficacy - pathogen eradication (random-effects model).

Analysis 1.3. Comparison 1 Different fluoroquinolones: levofloxacin versus ciprofloxacin, Outcome 3 Clinical efficacy.

Analysis 1.4. Comparison 1 Different fluoroquinolones: levofloxacin versus ciprofloxacin, Outcome 4 Adverse effects of treatment.

Analysis 2.1. Comparison 2 Different fluoroquinolones: prulifloxacin versus levofloxacin, Outcome 1 Microbiological efficacy - pathogen eradication.

Analysis 2.2. Comparison 2 Different fluoroquinolones: prulifloxacin versus levofloxacin, Outcome 2 Clinical efficacy NIH-CPSI total score at the end of treatment.

Analysis 2.3. Comparison 2 Different fluoroquinolones: prulifloxacin versus levofloxacin, Outcome 3 Adverse effects of treatment.

Analysis 3.1. Comparison 3 Different fluoroquinolones: lomefloxacin versus ofloxacin, Outcome 1 Microbiological efficacy - pathogen eradication at follow-up (6 months).

Analysis 3.2. Comparison 3 Different fluoroquinolones: lomefloxacin versus ofloxacin, Outcome 2 Adverse effects of treatment.

Analysis 4.1. Comparison 4 Different fluoroquinolones: lomefloxacin versus ciprofloxacin, Outcome 1 Microbiological efficacy (intention-to-treat analysis).

Analysis 4.2. Comparison 4 Different fluoroquinolones: lomefloxacin versus ciprofloxacin, Outcome 2 Microbiological efficacy (per-protocol analysis).

Analysis 4.3. Comparison 4 Different fluoroquinolones: lomefloxacin versus ciprofloxacin, Outcome 3 Clinical efficacy (intention-to-treat analysis).

Analysis 4.4. Comparison 4 Different fluoroquinolones: lomefloxacin versus ciprofloxacin, Outcome 4 Clinical efficacy (per-protocol analysis).

Analysis 4.5. Comparison 4 Different fluoroquinolones: lomefloxacin versus ciprofloxacin, Outcome 5 Adverse effects of treatment.

Analysis 5.1. Comparison 5 Different fluoroquinolones: lomefloxacin versus comparator fluoroquinolone, Outcome 1 Microbiological efficacy - pathogen eradication at follow-up (6 months).

Analysis 5.2. Comparison 5 Different fluoroquinolones: lomefloxacin versus comparator fluoroquinolone, Outcome 2 Adverse effects of treatment.

Analysis 6.1. Comparison 6 Different fluoroquinolones: ciprofloxacin versus comparator fluoroquinolone, Outcome 1 Microbiological efficacy - pathogen eradication at the end of treatment (fixed-effect model). 
Analysis 6.2. Comparison 6 Different fluoroquinolones: ciprofloxacin versus comparator fluoroquinolone, Outcome 2 Microbiological efficacy - pathogen eradication at the end of treatment (random-effects model). . . . . .

Analysis 6.3. Comparison 6 Different fluoroquinolones: ciprofloxacin versus comparator fluoroquinolone, Outcome 3 Clinical efficacy.

Analysis 6.4. Comparison 6 Different fluoroquinolones: ciprofloxacin versus comparator fluoroquinolone, Outcome 4 Adverse effects of treatment. . . . . . . . . . . . . . . . . . . . . . . . . . . . . . . . . . . . . . . . .

Analysis 7.1. Comparison 7 Different fluoroquinolones: levofloxacin versus comparator fluoroquinolone, Outcome 1 Microbiological efficacy - pathogen eradication (fixed-effect model). . . . . . . . . . . . . . . . . . .

Analysis 7.2. Comparison 7 Different fluoroquinolones: levofloxacin versus comparator fluoroquinolone, Outcome 2 Microbiological efficacy - pathogen eradication (random-effects model). . . . . . . . . . . . . . . . . .

Analysis 7.3. Comparison 7 Different fluoroquinolones: levofloxacin versus comparator fluoroquinolone, Outcome 3 Adverse effects of treatment. . . . . . . . . . . . . . . . . . . . . . . . . . . . . . . . . . .

Analysis 8.1. Comparison 8 Fluoroquinolone versus other antibacterial agent: prulifloxacin versus doxycycline in chlamydial prostatitis, Outcome 1 Microbiological efficacy - absence of Chlamydia trachomatis DNA and IgA at the end of treatment. . . . . . . . . . . . . . . . . . . . . . . . . . . . . . . . . . . .

Analysis 8.2. Comparison 8 Fluoroquinolone versus other antibacterial agent: prulifloxacin versus doxycycline in chlamydial prostatitis, Outcome 2 Clinical efficacy - NIH-CPSI total score at the end of treatment. . . . . . . . . . . 102

Analysis 8.3. Comparison 8 Fluoroquinolone versus other antibacterial agent: prulifloxacin versus doxycycline in chlamydial prostatitis, Outcome 3 Clinical efficacy - number of asymptomatic participants at the end of therapy. $\quad . \quad$. 102

Analysis 8.4. Comparison 8 Fluoroquinolone versus other antibacterial agent: prulifloxacin versus doxycycline in chlamydial prostatitis, Outcome 4 Adverse effects of treatment. . . . . . . . . . . . . . . . . . . . . . . . . . . . .

Analysis 9.1. Comparison 9 Fluoroquinolone versus other antibacterial agent: ofloxacin versus minocycline in ureaplasmal prostatitis, Outcome 1 Microbiological efficacy - pathogen eradication. . . . . . . . . . . . . . . . . .

Analysis 9.2. Comparison 9 Fluoroquinolone versus other antibacterial agent: ofloxacin versus minocycline in ureaplasmal prostatitis, Outcome 2 Clinical efficacy (cure or improvement) at the end of treatment. . . . . . . . . . .

Analysis 10.1. Comparison 10 Fluoroquinolone versus other antibacterial agent: ofloxacin versus carbenicillin, Outcome 1 Microbiological efficacy - pathogen eradication. . . . . . . . . . . . . . . . . . . . . . . . . . . . .

Analysis 10.2. Comparison 10 Fluoroquinolone versus other antibacterial agent: ofloxacin versus carbenicillin, Outcome 2 Clinical efficacy (cure or improvement) at the end of treatment. $\quad . \quad$. . . . . . . . . . . . . . . . . . . . . .

Analysis 10.3. Comparison 10 Fluoroquinolone versus other antibacterial agent: ofloxacin versus carbenicillin, Outcome 3

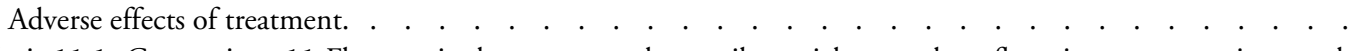

Analysis 11.1. Comparison 11 Fluoroquinolone versus other antibacterial agent: lomefloxacin versus co-trimoxazole, Outcome 1 Microbiological efficacy. . . . . . . . . . . . . . . . . . . . . . . . . . . . . .

Analysis 11.2. Comparison 11 Fluoroquinolone versus other antibacterial agent: lomefloxacin versus co-trimoxazole, Outcome 2 Clinical efficacy. . . . . . . . . . . . . . . . . . . . . . . . . . . . . . . . . . . . . . . . . . .

Analysis 11.3. Comparison 11 Fluoroquinolone versus other antibacterial agent: lomefloxacin versus co-trimoxazole, Outcome 3 Adverse effects of treatment. $\quad . \quad$. . . . . . . . . . . . . . . . . . . . . . . . . . . . . . . . . .

Analysis 12.1. Comparison 12 Fluoroquinolone versus other antibacterial agent: ciprofloxacin versus azithromycin in chlamydial prostatitis, Outcome 1 Microbiological efficacy (pathogen eradication) at the end of treatment. . .

Analysis 12.2. Comparison 12 Fluoroquinolone versus other antibacterial agent: ciprofloxacin versus azithromycin in chlamydial prostatitis, Outcome 2 Clinical efficacy (cure or improvement) at the end of treatment. . . . . . .

Analysis 12.3. Comparison 12 Fluoroquinolone versus other antibacterial agent: ciprofloxacin versus azithromycin in chlamydial prostatitis, Outcome 3 Adverse effects of treatment. . . . . . . . . . . . . . . . . . . . . . . . .

Analysis 13.1. Comparison 13 Non-fluoroquinolone antibacterial agents: minocycline versus cephalexin, Outcome 1 Microbiological efficacy (pathogen eradication and eradication plus superinfection) at the end of treatment. .

Analysis 13.2. Comparison 13 Non-fluoroquinolone antibacterial agents: minocycline versus cephalexin, Outcome 2 Clinical efficacy (cure or improvement) at the end of treatment.

Analysis 13.3. Comparison 13 Non-fluoroquinolone antibacterial agents: minocycline versus cephalexin, Outcome 3 Microbiological recurrence. . . . . . . . . . . . . . . . . . . . . . . . . . . . . . . . . . . . . .

Analysis 14.1. Comparison 14 Non-fluoroquinolone antibacterial agents: azithromycin versus clarithromycin in chlamydial prostatitis, Outcome 1 Microbiological efficacy (pathogen eradication) at the end of treatment. . . . . . . . 114

Analysis 14.2. Comparison 14 Non-fluoroquinolone antibacterial agents: azithromycin versus clarithromycin in chlamydial prostatitis, Outcome 2 Clinical efficacy (cure) at the end of treatment. . . . . . . . . . . . . . . . . . . . 114 
Analysis 14.3. Comparison 14 Non-fluoroquinolone antibacterial agents: azithromycin versus clarithromycin in chlamydial prostatitis, Outcome 3 Adverse effects of treatment. . . . . . . . . . . . . . . . . . . . . . . . . .

Analysis 15.1. Comparison 15 Non-fluoroquinolone antibacterial agents: azithromycin versus doxycycline in chlamydial prostatitis, Outcome 1 Microbiological efficacy (pathogen eradication) at the end of treatment. . . . . . .

Analysis 15.2. Comparison 15 Non-fluoroquinolone antibacterial agents: azithromycin versus doxycycline in chlamydial prostatitis, Outcome 2 Clinical efficacy. . . . . . . . . . . . . . . . . . . . . . . . . . . . . . .

Analysis 15.3. Comparison 15 Non-fluoroquinolone antibacterial agents: azithromycin versus doxycycline in chlamydial prostatitis, Outcome 3 Adverse effects of treatment. . . . . . . . . . . . . . . . . . . . . . . . . .

Analysis 16.1. Comparison 16 Non-fluoroquinolone antibacterial agents: azithromycin versus doxycycline in ureaplasmal prostatitis, Outcome 1 Microbiological efficacy (pathogen eradication) at the end of treatment. . . . . . .

Analysis 16.2. Comparison 16 Non-fluoroquinolone antibacterial agents: azithromycin versus doxycycline in ureaplasmal prostatitis, Outcome 2 Clinical efficacy (cure) at the end of treatment. . . . . . . . . . . . . . . . . . .

Analysis 16.3. Comparison 16 Non-fluoroquinolone antibacterial agents: azithromycin versus doxycycline in ureaplasmal prostatitis, Outcome 3 Adverse effects of treatment. . . . . . . . . . . . . . . . . . . . . . . . . .

Analysis 17.1. Comparison 17 Different dosing regimens: azithromycin $4.5 \mathrm{~g}$ versus $6.0 \mathrm{~g}$ total doses in chlamydial prostatitis, Outcome 1 Microbiological efficacy (pathogen eradication) at the end of treatment. . . . . . .

Analysis 17.2. Comparison 17 Different dosing regimens: azithromycin $4.5 \mathrm{~g}$ versus $6.0 \mathrm{~g}$ total doses in chlamydial prostatitis, Outcome 2 Clinical efficacy (cure) at the end of therapy. . . . . . . . . . . . . . . . . .

Analysis 17.3. Comparison 17 Different dosing regimens: azithromycin $4.5 \mathrm{~g}$ versus $6.0 \mathrm{~g}$ total doses in chlamydial prostatitis, Outcome 3 Adverse effects of treatment. . . . . . . . . . . . . . . . . . . . . . . . . .

Analysis 18.1. Comparison 18 Different therapy duration: co-trimoxazole $480 \mathrm{mg}$ twice daily for 12 weeks versus 10 days, Outcome 1 Microbiological efficacy (pathogen eradication) at the end of treatment. . . . . . . . . .

Analysis 18.2. Comparison 18 Different therapy duration: co-trimoxazole $480 \mathrm{mg}$ twice daily for 12 weeks versus 10 days, Outcome 2 Adverse effects of treatment.

Analysis 19.1. Comparison 19 Fluoroquinolone combined with phosphodiesterase-5 inhibitor versus fluoroquinolone: levofloxacin plus vardenafil $10 \mathrm{mg}$ /day versus levofloxacin, Outcome 1 Microbiological efficacy (pathogen eradication) at the end of treatment. $\quad . \quad$. . . . . . . . . . . . . . . . . . . . . . . . . . . . . . . . . . . . .

Analysis 19.2. Comparison 19 Fluoroquinolone combined with phosphodiesterase-5 inhibitor versus fluoroquinolone: levofloxacin plus vardenafil $10 \mathrm{mg} /$ day versus levofloxacin, Outcome 2 Clinical efficacy - NIH-CPSI score at the end of treatment. . . . . . . . . . . . . . . . . . . . . . . . . . . . . . . . . . .

Analysis 19.3. Comparison 19 Fluoroquinolone combined with phosphodiesterase-5 inhibitor versus fluoroquinolone: levofloxacin plus vardenafil $10 \mathrm{mg} /$ day versus levofloxacin, Outcome 3 Clinical efficacy - number of participants with leukocytosis in post-massage urine specimens at the end of treatment. $\quad . \quad$. . . . . . . . . . . . . . . .

Analysis 19.4. Comparison 19 Fluoroquinolone combined with phosphodiesterase-5 inhibitor versus fluoroquinolone: levofloxacin plus vardenafil $10 \mathrm{mg} /$ day versus levofloxacin, Outcome 4 Clinical efficacy - urine peak flow rate at the

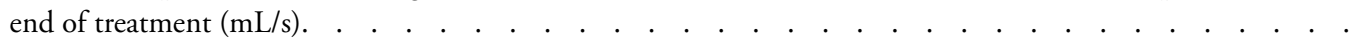

Analysis 20.1. Comparison 20 Fluoroquinolone combined with phosphodiesterase-5 inhibitor versus fluoroquinolone: levofloxacin plus vardenafil $10 \mathrm{mg}$ on-demand versus levofloxacin, Outcome 1 Microbiological efficacy (pathogen eradication) at the end of treatment. . . . . . . . . . . . . . . . . . . . . . . . . . . . . . . . . . . . .

Analysis 20.2. Comparison 20 Fluoroquinolone combined with phosphodiesterase-5 inhibitor versus fluoroquinolone: levofloxacin plus vardenafil $10 \mathrm{mg}$ on-demand versus levofloxacin, Outcome 2 Clinical efficacy - NIH-CPSI score at the end of treatment. . . . . . . . . . . . . . . . . . . . . . . . . . . . . . . . . . . . . . .

Analysis 20.3. Comparison 20 Fluoroquinolone combined with phosphodiesterase-5 inhibitor versus fluoroquinolone: levofloxacin plus vardenafil $10 \mathrm{mg}$ on-demand versus levofloxacin, Outcome 3 Clinical efficacy - number of participants with leukocytosis in post-massage urine specimens at the end of treatment. . . . . . . . . . .

Analysis 20.4. Comparison 20 Fluoroquinolone combined with phosphodiesterase-5 inhibitor versus fluoroquinolone: levofloxacin plus vardenafil $10 \mathrm{mg}$ on-demand versus levofloxacin, Outcome 4 Clinical efficacy - urine peak flow rate

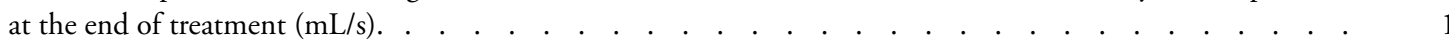

Analysis 21.1. Comparison 21 Fluoroquinolone combined with phosphodiesterase-5 inhibitor: levofloxacin plus vardenafil $10 \mathrm{mg} /$ day versus levofloxacin plus vardenafil $10 \mathrm{mg}$ on-demand, Outcome 1 Microbiological efficacy (pathogen eradication) at the end of treatment. . . . . . . . . . . . . . . . . . . . . . . . . . . . . . . .

Antimicrobial therapy for chronic bacterial prostatitis (Review) 
Analysis 21.2. Comparison 21 Fluoroquinolone combined with phosphodiesterase-5 inhibitor: levofloxacin plus vardenafil $10 \mathrm{mg} /$ day versus levofloxacin plus vardenafil $10 \mathrm{mg}$ on-demand, Outcome 2 Clinical efficacy - NIH-CPSI score at the end of treatment. . . . . . . . . . . . . . . . . . . . . . . . . . . . . . . . . . . . . . . . . . . . . .

Analysis 21.3. Comparison 21 Fluoroquinolone combined with phosphodiesterase-5 inhibitor: levofloxacin plus vardenafil $10 \mathrm{mg} /$ day versus levofloxacin plus vardenafil $10 \mathrm{mg}$ on-demand, Outcome 3 Clinical efficacy - number of participants with leukocytosis in post-massage urine specimens at the end of treatment. . . . . . . . . . . . . . . . . .

Analysis 21.4. Comparison 21 Fluoroquinolone combined with phosphodiesterase-5 inhibitor: levofloxacin plus vardenafil $10 \mathrm{mg} /$ day versus levofloxacin plus vardenafil $10 \mathrm{mg}$ on-demand, Outcome 4 Clinical efficacy - urine peak flow rate at

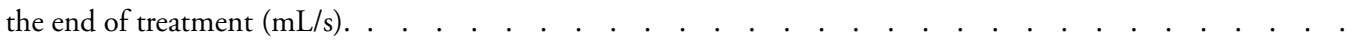

Analysis 22.1. Comparison 22 Fluoroquinolone plus herbal extracts or supplements versus fluoroquinolone: prulifloxacin plus supplements versus prulifloxacin, Outcome 1 Clinical efficacy - NIH-CPSI total score. . . . . . . . .

Analysis 22.2. Comparison 22 Fluoroquinolone plus herbal extracts or supplements versus fluoroquinolone: prulifloxacin plus supplements versus prulifloxacin, Outcome 2 Clinical efficacy - IPSS score. . . . . . . . . . . . . .

Analysis 22.3. Comparison 22 Fluoroquinolone plus herbal extracts or supplements versus fluoroquinolone: prulifloxacin plus supplements versus prulifloxacin, Outcome 3 Adverse effects of treatment. . . . . . . . . . . . . 138

CONTRIBUTIONS OF AUTHORS . . . . . . . . . . . . . . . . . . . . . . . . . . . . . . 138

DECLARATIONS OF INTEREST . . . . . . . . . . . . . . . . . . . . . . . . . . . . . . . 138

SOURCES OF SUPPORT . . . . . . . . . . . . . . . . . . . . . . . . . . . . . . . . . . . . . . . . . . . . . . . . . .

DIFFERENCES BETWEEN PROTOCOL AND REVIEW . . . . . . . . . . . . . . . . . . . . . . 139

INDEX TERMS . . . . . . . . . . . . . . . . . . . . . . . . . . . . . . . . . . . . . 139 


\title{
[Intervention Review]
}

\section{Antimicrobial therapy for chronic bacterial prostatitis}

\author{
Gianpaolo Perletti ${ }^{1,2}$, Emanuela Marras ${ }^{3}$, Florian ME Wagenlehner ${ }^{4}$, Vittorio Magri ${ }^{5}$ \\ ${ }^{1}$ Laboratory of Toxicology and Pharmacology, Biomedical Research Division, Dept. of Theoretical and Applied Sciences, Università degli \\ Studi dell'Insubria, Busto A, Italy. ${ }^{2}$ Department of Basic Medical Sciences, Faculty of Medicine and Health Sciences, Ghent University, \\ Ghent, Belgium. ${ }^{3}$ Laboratory of Toxicology and Pharmacology, Biomedical Research Division, Dept. of Theoretical and Applied \\ Sciences, Università degli Studi dell'Insubria, Busto A, Italy. ${ }^{4}$ Klinik und Poliklinik für Urologie, Kinderurologie und Andrologie, \\ Justus Liebig University of Gießen, Gießen, Germany. ${ }^{5}$ Urology/Urological Sonography Secondary Care Clinic, Istituti Clinici di \\ Perfezionamento, Milano, Italy \\ Contact address: Gianpaolo Perletti, Laboratory of Toxicology and Pharmacology, Biomedical Research Division, Dept. of Theoret- \\ ical and Applied Sciences, Università degli Studi dell'Insubria, Via A. da Giussano, 10, Busto A, Province of Varese, 21052, Italy. \\ gianpaolo.perletti@uninsubria.it.
}

Editorial group: Cochrane Urology Group.

Publication status and date: New, published in Issue 8, 2013.

Review content assessed as up-to-date: 8 August 2012.

Citation: Perletti G, Marras E, Wagenlehner FME, Magri V. Antimicrobial therapy for chronic bacterial prostatitis. Cochrane Database of Systematic Reviews 2013, Issue 8. Art. No.: CD009071. DOI: 10.1002/14651858.CD009071.pub2.

Copyright (C) 2013 The Cochrane Collaboration. Published by John Wiley \& Sons, Ltd.

\begin{abstract}
A B S T R A C T
Background

Chronic bacterial prostatitis (CBP) is frequently diagnosed in men of fertile age, and is characterized by a disabling array of symptoms, including pain in the pelvic area (for example, perineum, testicles), voiding symptoms (increased frequency and urgency, also at night; pain or discomfort at micturition), and sexual dysfunction. Cure of CBP can be attempted by long-term therapy with antibacterial agents, but relapses are frequent. Few antibacterial agents are able to distribute to the prostatic tissue and achieve sufficient concentrations at the site of infection. These agents include fluoroquinolones, macrolides, tetracyclines and trimethoprim. After the introduction of fluoroquinolones into clinical practice, a number of studies have been performed to optimize the antimicrobial treatment of CBP, and to improve eradication rates and symptom relief.
\end{abstract}

\section{Objectives}

To assess and compare the efficacy and harm of antimicrobial treatments for chronic bacterial prostatitis.

\section{Search methods}

We searched the Cochrane Central Register of Controlled Trials (CENTRAL), MEDLINE (PubMed), EMBASE, other national or international databases and abstracts from conference proceedings on 8 August 2012.

\section{Selection criteria}

We included all randomized controlled comparisons of one antimicrobial agent versus placebo or one or more comparator antimicrobial agents, combined or not with non-antimicrobial drugs. We also included trials comparing different doses, treatment durations, dosing frequencies, or routes of administration of antimicrobial agents. We excluded studies in which patients were not diagnosed according to internationally recommended criteria, or were not subjected to lower urinary tract segmented tests.

Antimicrobial therapy for chronic bacterial prostatitis (Review)

Copyright @ 2013 The Cochrane Collaboration. Published by John Wiley \& Sons, Ltd. 


\section{Data collection and analysis}

Study data were extracted independently by two review authors. Study outcomes were microbiological efficacy (pathogen eradication), clinical efficacy (symptom cure or improvement, or symptom scores) at test-of-cure visits or at follow-up, or both, and adverse effects of therapy. Secondary outcomes included microbiological recurrence rates.

Statistical analysis was performed using a fixed-effect model for microbiological outcomes and a random-effects model for clinical outcomes and adverse effects. The results were expressed as risk ratios for dichotomous outcomes (with $95 \%$ confidence intervals) or as standardized mean differences for continuous or non-dichotomous variables.

\section{Main results}

We identified 18 studies, enrolling a total of 2196 randomized patients. The oral fluoroquinolones ciprofloxacin, levofloxacin, lomefloxacin, ofloxacin and prulifloxacin were compared. There were no significant differences in clinical or microbiological efficacy or in the rate of adverse effects between these fluoroquinolones. In chlamydial prostatitis, (i) azithromycin showed improved eradication rates and clinical cure rates compared to ciprofloxacin, with no significant differences regarding adverse effects; (ii) azithromycin was equivalent to clarithromycin, both microbiologically and clinically; (iii) prulifloxacin appeared to improve clinical symptoms, but not eradication rates, compared to doxycycline. In ureaplasmal prostatitis, the comparisons ofloxacin versus minocycline and azithromycin versus doxycycline showed similar microbiological, clinical and toxicity profiles.

\section{Authors' conclusions}

The microbiological and clinical efficacy, as well as the adverse effect profile, of different oral fluoroquinolones are comparable. No conclusions can be drawn regarding the optimal treatment duration of fluoroquinolones in the treatment of CBP caused by traditional pathogens.

Alternative antimicrobial agents tested for the treatment of CBP caused by traditional pathogens are co-trimoxazole, beta-lactams and tetracyclines, but no conclusive evidence can be drawn regarding the role of non-fluoroquinolone antibiotics in the treatment of CBP caused by traditional pathogens.

In patients with CBP caused by obligate intracellular pathogens, macrolides showed higher microbiological and clinical cure rates compared to fluoroquinolones.

\section{PLAIN LANGUAGE SUMMARY}

\section{Interventions to treat chronic infection of the prostate gland (chronic bacterial prostatitis)}

Chronic bacterial prostatitis (CBP) involves infection and inflammation of the prostate gland in men of all ages. It can cause problems urinating, including discomfort and pain, increased frequency and urge, or problems emptying the bladder. Bacteria infecting the prostate are the cause of CBP. These bacteria may be sexually transmitted. To cure CBP, antibiotics must be administered for extended periods of time (four weeks or longer), but a permanent cure is not always guaranteed. Other drugs may be combined with antibiotics to improve $\mathrm{CBP}$ symptoms. This review found that fluoroquinolones like ciprofloxacin, levofloxacin, lomefloxacin, ofloxacin or prulifloxacin have equivalent effects and equivalent success rates in CBP patients. If atypical bacteria like chlamydia are suspected to cause CBP, macrolide antibiotics such as azithromycin may achieve better results compared to the fluoroquinolone ciprofloxacin. It must be taken into account that some of the studies that have been performed are of poor quality or have been performed on small numbers of participants. More studies are needed, focusing on new agents or on optimized doses of currently prescribed antibiotics. 


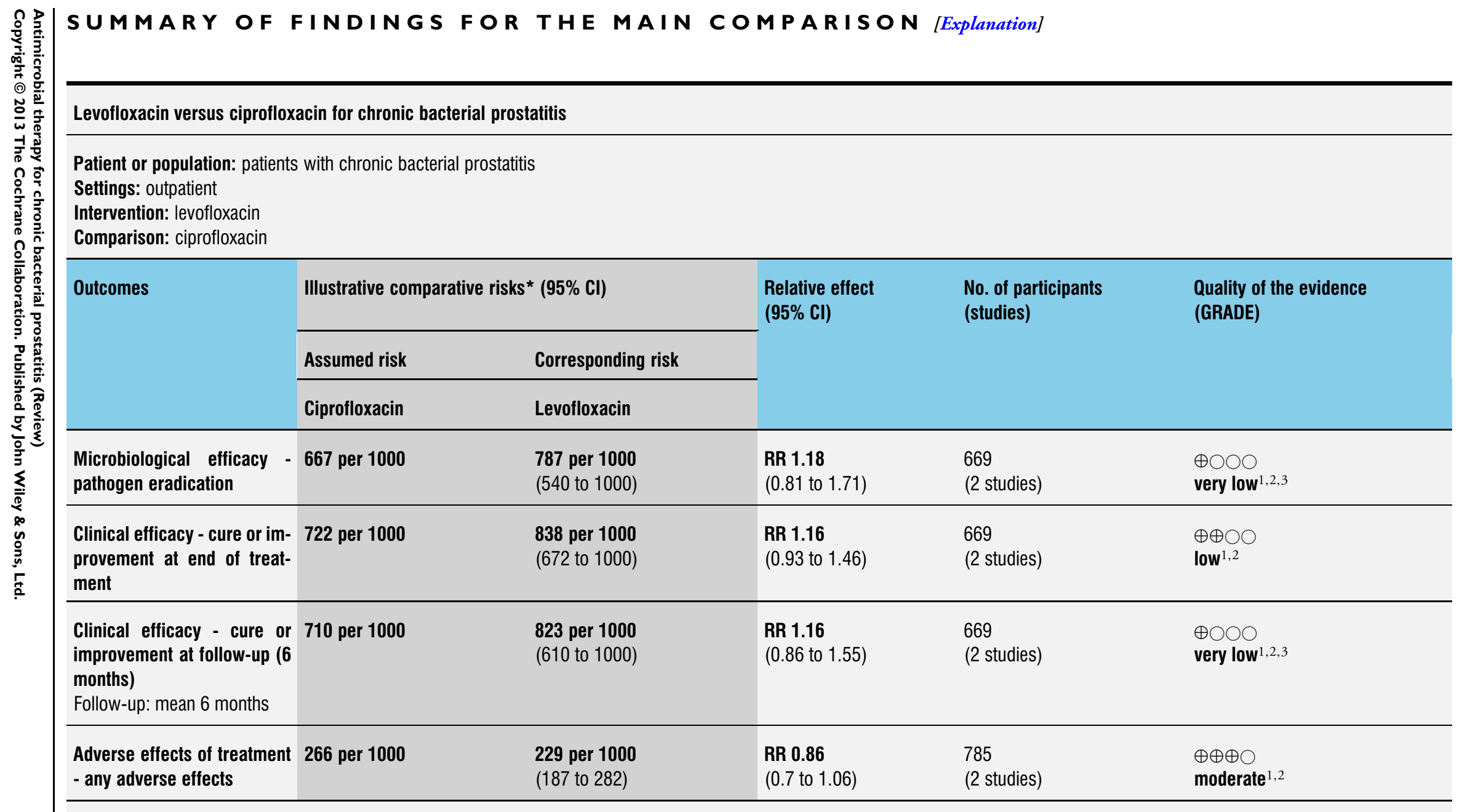

*The basis for the assumed risk (e.g. the median control group risk across studies) is provided in footnotes. The corresponding risk (and its $95 \% \mathrm{Cl}$ ) is based on the assumed risk in the comparison group and the relative effect of the intervention (and its $95 \% \mathrm{Cl}$ ).

Cl: Confidence interval; No.: Number; RR: Risk ratio 
GRADE Working Group grades of evidence

High quality: Further research is very unlikely to change our confidence in the estimate of effect.

Moderate quality: Further research is likely to have an important impact on our confidence in the estimate of effect and may change the estimate.

Low quality: Further research is very likely to have an important impact on our confidence in the estimate of effect and is likely to change the estimate.

Very low quality: We are very uncertain about the estimate.

${ }^{1}$ Bundrick 2003 - high risk of reporting bias.

2 Zhang 2012 - high risk of performance bias, reporting bias and other bias (study design).

${ }^{3}$ Results show inconsistency/heterogeneity (Analysis 1 ). 


\section{B A C K G R O U N D}

\section{Description of the condition}

Prostatitis syndromes represent the most frequent urological diagnosis in men below 50 years of age, and they are the third most common diagnosis among individuals beyond that age (Collins 1998).

The prevalence of chronic prostatitis-like symptoms ranges between $2 \%$ and $13 \%$ worldwide, depending on the type of study and on the population examined (Bartoletti 2007; Ejike 2008; Ferris 2010; Krieger 2008; Liang 2009; Mehik 2000; Nickel 2001; Rizzo 2003; Wallner 2009). Analysis of the United States (US) Kaiser Permanente Northwest database (Portland, Oregon) showed that between 2002 and 2004 the incidence of physician-diagnosed prostatitis was 4.9 per 1000 person-years (Clemens 2005).

The age-adjusted annualized visit rate for prostatitis is 17,980 per million population in the US, and prostatitis accounted for a total of 8,021,396 physician office visits (with any diagnosis) between the years 1992 and 2000. The total US spending for the diagnosis and management of prostatitis in year 2000, not including pharmaceutical expenses, was 84 million USD (McNaughton-Collins 2007; Pontari 2007). The economic impact of visits and tests for prostatitis in the US, assessed in year 2009, ranged between 3017 USD (Medicare rates) and 6534 USD (non-Medicare rates) per patient per year (Clemens 2009).

Chronic prostatitis syndromes are traditionally classified as 'bacterial' or 'abacterial'.

According to the most recent National Institutes of Health - National Institute of Diabetes and Digestive and Kidney Diseases (NIH-NIDDK) consensus definition, category II chronic bacterial prostatitis (CBP) occurs when patients experience recurrent symptomatic episodes of urinary tract infection caused by the same organism (usually E. coli, or another Gram-negative organism (for example, Klebsiella spp.,Proteusspp.,Pseudomonasspp.) or Enterococcus faecalis). Between symptomatic episodes of bacteriuria, lower urinary tract cultures can document an infected prostate gland as the focus of these recurrent infections (Krieger 1999). Besides these commonly recognized pathogens, Staphylococcus aureus is frequently included among the causative agents of CBP (for example, Naber 2008; British National Guidelines: www.bashh.org/ guidelines). Other bacteria have been investigated in recent years, but a general consensus on their pathogenic role in CBP is still awaited.

The vast majority of men with chronic prostatitis (about 90\% of all prostatitis cases) (Lipsky 2010; McNaughton-Collins 2007) present with pelvic pain and voiding symptoms without evidence of bacterial infection, and are diagnosed with chronic (abacterial) prostatitis/chronic pelvic pain syndrome (CP/CPPS, NIH-NIDDK category III) (Krieger 1999; McNaughton-Collins 2007). CP/CPPS is mainly characterized by pain in the perineum, prostate, rectum, penis, testicles and abdomen. It is often associ- ated with dysuria (painful voiding), with symptoms of obstruction on voiding (for example, hesitancy, weak or intermittent stream), with irritative symptoms (for example, increased frequency, urgency, nocturia (night-time urination)), and sometimes with sexual dysfunction (Mehik 2001).

Symptoms of CBP and CP/CPPS frequently overlap. Since the clinical presentation of patients with CBP or CP/CPPS is similar, and given that there is no gold standard diagnostic test for the latter, CP/CPPS is mainly diagnosed by excluding the presence of category II CBP (McNaughton-Collins 2007).

Although patients suffering from prostatitis with a recognized bacterial etiology are only $5 \%$ to $10 \%$ of all men showing symptoms of chronic prostatitis (McNaughton-Collins 2007), bacterial infection is reputed to be a possible pathogenic factor in the early 'etiological pathway' of CP/CPPS (Daniels 2007; Nickel 2010; Shoskes 2009). However, CP/CPPS is defined and diagnosed as an abacterial form of chronic prostatitis and antimicrobial treatment is not effective for this specific syndrome (Cohen 2012).

Microbiological diagnosis of CBP is based on nding substantially lower (one tenth or less) bacterial counts in urine specimens from the urethra (first-voided urine, or VB1) and bladder (midstream urine, or VB2) compared with counts in prostatic secretions expressed during prostatic massage (EPS) or in post-massage voided urine (VB3). Such segmented microbiological analysis of men's lower urinary tract is commonly referred to as the 'four-glass test' according to Meares and Stamey (Stamey 1981). Although never validated in a randomized setting, the four-glass test is considered to be a standard analytical procedure for diagnosing CBP as well as for discriminating between $\mathrm{CBP}$ and CP/CPPS. A test based on bacteriological culture of the pre-massage and post-prostatic massage voided urine (PPMT, or 'two-glass' assay) has been proposed as a simplified alternative to the four-glass test (Nickel 2006). Although a study comparing the two tests in patients diagnosed with CP/CPPS showed that the PPMT could detect uropathogens in fewer cases $(44 \%)$ compared to the traditional four-glass assay (Nickel 2006), the former is considered a preferable alternative to simple urine or semen cultures.

\section{Description of the intervention}

The therapy of CBP is based on the administration of antibacterial agents for several weeks.

Fluoroquinolones are currently indicated as first-choice antibacterial agents for treatment of category II CBP. International recommendations and guidelines indicate a four to 12-week course of ciprofloxacin, lomefloxacin, ofloxacin, levofloxacin or norfloxacin for the eradication of susceptible pathogens (European Association of Urology (EAU) Urological Infections Guidelines: www.uroweb.org/guidelines/online-guidelines/; United Kingdom (UK) National Guidelines: www.bashh.org/guidelines; Canadian guidelines: www.phac-aspc.gc.ca/std-mts/sti-its/guide-lignesdireng.php; Lipsky 2010; Wagenlehner 2007). 
Trimethoprim, combined or not with sulfamethoxazole, was formerly the most prescribed drug for the treatment of CBP (Meares 1975). Due to the low eradication rates achieved with trimethoprim, this drug is now indicated as a second-choice agent in case of bacterial resistance to fluoroquinolones or in case of poor tolerability of the first-choice agents (EAU Guidelines: www.uroweb.org/ gls/pdf/18_Urological\%20infections_LR.pdf).

Macrolides and tetracyclines are also recommended for treatment of CBP, but their use is presently restricted to special indications (for example, chlamydial infection) (EAU Guidelines: www.uroweb.org/gls/pdf/18_Urological\%20infections_LR.pdf; Lipsky 2010; Nickel 2008b).

Patients with frequent recurrences may be placed on antibiotic prophylaxis for several months (for example, low-dose co-trimoxazole). However, evidence-based proof of efficacy of such a strategy is lacking.

\section{How the intervention might work}

The number of antibacterial agents suitable for treatment of category II CBP is very limited. Fluoroquinolones, trimethoprim and macrolides are among the few antibacterial agents that can penetrate the prostate sufficiently to reach levels exceeding the minimal concentrations inhibiting the growth (MIC) of most infecting pathogens (Foulds 1991).

Lipophilicity and a high pKa (acid dissociation constant) are considered important features of antibacterial agents for the treatment of CBP (Shoskes 2001). To achieve suitable prostatic concentrations, a drug must be sufficiently lipophilic to cross the many barriers separating the prostatic vasculature from the target site of action, and to reach the pathogens infecting the prostatic glands and ducts and, in some cases, the intracellular compartments (Naber 2003; Perletti 2009).

The $\mathrm{pH}$ at the site of action can also affect the pharmacodynamic properties of antibacterial agents. The milieu of the infected human prostate is alkaline $(\mathrm{pH}=8.34)$ (Naber 2003). It has been demonstrated that alkalinization of the $\mathrm{pH}$ can significantly decrease (10- to 30-fold) the MICs of fluoroquinolones against $E$. coli and other uropathogens (Aagaard 1991; Gesu 1987; Kamberi 1999). The activity of macrolides is also influenced by the $\mathrm{pH}$ at the site of action; for example, the MIC of azithromycin $(\mathrm{pKa}=$ 9.5) against Staphylococcus aureus is 64, 1 and 0.03 at $\mathrm{pH} \mathrm{6,7}$ and 8, respectively (Dalhoff 2005).

\section{Why it is important to do this review}

Firstly, most current therapeutic recommendations for CBP are based on data from randomized trials, non-randomized clinical evidence, or on the clinical experience and opinion of leading experts. The fact that contemporary guidelines are not based on systematic reviews of the literature and the meta-analysis of available data represents a major limitation in this regard. One example is 'suppressive' long-term therapy with low-dose trimethoprim. This recommendation is not substantiated by clinical data.

Secondly, the current antibacterial dosing regimens for CBP are mainly based on 'trial-and-error' empirical strategies, regimens adopted for other infectious diseases, or on safety data. Pharmacokinetic and pharmacodynamic parameters for the treatment of CBP, focusing on dosage issues, are almost non-existent. The results of studies comparing different doses of antibacterial agents or different durations of therapy should be analyzed and reviewed. Thirdly, the adjuvant effect of compounds administered in combination with antibacterials (for example, alpha-adrenoceptor blockers) is controversial. Few of these combinations have been tested in the framework of randomized controlled trials (RCTs). The results of these studies must be thoroughly analyzed to improve clinical decision-making and patient management.

Fourthly, the efficacy of interventions different from established long-term oral antibacterial regimens (for example, intraprostatic injection of antibacterial agents) is debated. The results of RCTs involving alternative administration routes for antibiotics must be reviewed and thoroughly analyzed to improve clinical decisionmaking and patient management.

Finally, the world-wide increasing fluoroquinolone resistance in Gram-negative pathogens poses new therapeutical problems also in the antibacterial treatment of CBP. For example, the activity of second-generation fluoroquinolones like ciprofloxacin is hampered by the novel resistance determinant aac (6')-Ib-cr, whereas unique structural features make molecules like levofloxacin unaffected by aac (6')-Ib-cr. Thus, fluoroquinolone clinical trials published in the past must be reviewed in a contemporary perspective. Moreover, studies published in the past may have lost relevance due to diffuse drug resistance.

In conclusion, a systematic review may help improve current therapeutic guidelines on the basis of the evidence available from quality RCTs, and may improve the nature and grade of clinical recommendations and the management of patients affected by CBP.

\section{O B J E C T I V E S}

To assess and compare the efficacy and harms of antimicrobial treatments for CBP.

\section{METHODS}

\section{Criteria for considering studies for this review}

Types of studies 
All RCTs in which antimicrobial therapy was used to treat CBP.

\section{Types of participants}

Patients with category II (NIH-NIDDK) CBP (Krieger 1999), or with CBP according to the earlier classification by Drach et al (Drach 1978).

According to the Drach definition, CBP is diagnosed when pathogenic bacteria are recovered in significant numbers from a purulent prostatic fluid in the absence of concomitant urinary tract infection or significant systemic signs (Drach 1978).

A clinical diagnosis of CBP is mainly based on three criteria: a history of CBP, current clinical signs and symptoms of prostatitis, and laboratory evidence of prostatic infection in expressed prostatic secretions or post-massage voided urine.

Studies focusing on patients affected by category I acute bacterial prostatitis, category III CP/CPPS, or category IV asymptomatic inflammatory prostatitis (NIH-NIDDK criteria), or by acute bacterial prostatitis, chronic non-bacterial prostatitis or prostatodynia (Drach 1978 classification) were excluded.

Studies not providing microbiological findings from adequate lower urinary tract segmented tests (Meares and Stamey '4-glass' test, '2-glass' pre- and post-massage test) were excluded. Studies including patients with poorly defined infections or conditions (for example, unclassified 'prostatitis' or 'chronic prostatitis' ' prostatoepididimo-vesiculitis'; 'genital tract infection including prostatitis'; etc.) were excluded.

\section{Types of interventions}

1. We considered all randomized controlled comparisons of one antimicrobial agent versus placebo, versus a different antimicrobial agent, or versus two or more combined antimicrobial agents.

2. Trials comparing different doses, different treatment durations, different dosing frequencies, or different routes of administration of antimicrobial agents were also considered to be acceptable for inclusion, as these regimens are likely to differ in their pharmacodynamic and pharmacokinetic properties and thus may differ in their efficacy.

3. We also considered randomized controlled comparisons of antimicrobial agents alone with antimicrobial agents combined with non-antibacterial drugs or physical interventions aimed at improving the microbiological or clinical efficacy of therapy as well as drug pharmacokinetics.

\section{Types of outcome measures}

\section{Primary outcomes}

1. Microbiological efficacy, defined as yielding at test-of-cure (TOC) visit sterile cultures of expressed prostatic secretions or post-massage urine, or positive cultures with a bacterial load inferior to a defined threshold (e.g., $10^{3}$ colony-forming units $(\mathrm{CFU}) / \mathrm{mL})$.

2. Clinical efficacy, defined as cure, resolution or improvement of signs and symptoms of CBP at the TOC visit or at follow-up, or assessed with strategies based on subjective or objective findings:

i) subjective clinical outcomes included symptom scores, bother scores, quality of life (QoL) scores, global urinary or systemic symptom reports, or patient self-declared status (e.g., improved, unchanged or worsened);

ii) objective clinical outcomes included the results of urodynamic or sonographic evaluations, prostate examination (tenderness, size, consistency, symmetry), microscopy of specimens of lower urinary tract segmented tests (white blood cell counts), biochemical markers (e.g., prostate-specific antigen (PSA)).

3. Adverse effects of treatment subgrouped or not for type, severity, or drug class.

\section{Secondary outcomes}

Microbiological recurrence, defined as reappearance of a pathogen or increase of its load over a defined threshold (for example, $>10^{3}$ $\mathrm{CFU} / \mathrm{mL}$ ) after (apparent) eradication, assessed at the TOC visit.

\section{Search methods for identification of studies}

\section{Electronic searches}

Clinical trials for CBP were identified through MEDLINE (1966 to 8 August 2012) by crossing the sensitivity-maximizing version of the Cochrane highly sensitive search strategy for identifying randomized trials in MEDLINE (2008 revision) (Higgins 2011) with the Boolean logic structure (item \#6 of the following list):

1. 'prostatitis[MeSH]', (including all subheadings)

2. '(prostatitis) NOT (prostatitis[MeSH Terms])'

3. '(prostato-vesic*[Title/Abstract]) OR (prostatovesic*[Title/ Abstract]) OR (prostato ADJ vesic*[Title/Abstract])'

4. '(vesiculo-prostat*[Title/Abstract]) OR (vesiculoprostat*[Title/Abstract]) OR (vesiculo ADJ prostat*[Title/Abstract])'

5. '(prostate OR prostate[MeSH Terms]) AND (bacterial infections and mycoses[MeSH Terms])'

6. \#1 OR \#2 OR \#3 OR \#4 OR \#5

The specialized PROSTATE register of the Cochrane Prostatic Diseases and Urologic Cancers Group, Cochrane Central Register of Controlled Trials (CENTRAL) and EMBASE databases were searched in an analogous fashion. 


\section{Searching other resources}

The meta-register of Current Controlled Trials (controlledtrials.com) and the US registry of clinical trials (clinicaltrials.gov) were searched for protocols and results of RCTs on CBP.

International and national databases (for example, LILACS, Panteleimon, IMSEAR, WPRIM, IndMed, KoreaMed, PASCAL, Australasian Medical Index, Eastern-Mediterranean Index Medicus) were also searched.

Handsearching was performed on the web pages containing the abstracts of all scientific contributions presented at international meetings of the European Association of Urology (http:/ /www.uroweb.org/), American Urological Association (http:// www.auanet.org/), International Society of Chemotherapy (http:/ /www.ischemo.org/), and the International Continence Society (http://www.icsoffice.org/Events/EventsIndex.aspx). The general term 'prostatitis' was used for the abstract search.

One systematic review of the literature was retrieved (Erickson 2008). This review was also searched for studies.

\section{Data collection and analysis}

\section{Selection of studies}

1. The titles and abstracts obtained with the search strategy described above were screened independently by two review authors (GP, EM). Studies deemed to be not eligible for the systematic review were excluded. Reviews or manuscripts that might include relevant data or information on studies were retained initially.

2. Two review authors (GP, FMEW) independently assessed the retrieved abstracts and, if necessary, the full text of these studies to determine which studies satisfied the inclusion criteria.

3. Discrepancies in the eligibility of retrieved studies were resolved by discussion. If necessary, the Cochrane Prostatic Diseases and Urologic Cancers Group was involved for arbitration.

\section{Data extraction and management}

Data extraction was performed independently by two review authors (GP, FMEW), using a modified version of a standard data extraction form provided by the Cochrane Renal Group.

Studies were eligible if they were randomized, involved a placebo control group or an active drug comparison group, involved patients with CBP diagnosed according to NIH or Drach 1978 criteria, and if diagnosis at enrolment was performed using an adequate lower urinary tract segmented bacteriological test (4-glass or 2-glass).

Discrepancies or disagreements were resolved by discussion and, if necessary, by arbitration involving the Cochrane Prostatic Diseases and Urologic Cancers Group. Studies reported in non-English language journals were tentatively translated before assessment, asking for the collaboration of the original authors of the reports. Any further information required from the original authors was obtained by correspondence and, if relevant, was included in the review. Where more than one publication of one trial was found, reports were grouped together and the most complete data set was used.

\section{Assessment of risk of bias in included studies}

The risk of bias of included studies was assessed by two independent review authors (FMEW, GP), without blinding to authorship or journal. The following items were assessed using the Cochrane Collaboration tool for assessing risk of bias (Higgins 2011).

1. Random sequence generation.

2. Allocation concealment.

3. Blinding of participants and personnel.

4. Blinding of outcome assessment.

5. Incomplete outcome data.

6. Selective reporting.

7. Other sources of bias.

'Risk of bias' tables were generated for each included study and were summarized in a 'Risk of bias' summary figure.

In the present review, risk of bias was a fundamental component of the analysis of the quality of evidence according to the GRADE approach (Higgins 2011). Quality of the evidence was graded as high, moderate, low or very low. In the case of low risk of bias, no downgrading of a study was deemed necessary. In the case of unclear risk of bias, or in the presence of biases raising doubts about the estimate of the effect and the results, a study was downgraded one level (for example, 'moderate' to 'low'). In the case of high risk of bias, the quality of the evidence was downgraded one or two levels (for example, 'moderate' to 'very low') depending on the severity of biases seriously weakening confidence in the results.

\section{Measures of treatment effect}

For dichotomous outcomes (for example, microbiological efficacy (number of patients showing eradication versus persistence), clinical efficacy (number of patients undergoing cure or improvement versus failure), adverse effects (number of patients showing the adverse effect)) results were expressed as risk ratios (RRs).

In the presence of ordinal outcomes (for example, mild, moderate or severe symptoms), these were dichotomized (for example, mild versus moderate or severe symptoms).

Where non-dichotomous scales were used to assess the effects of treatment (for example, symptom, bother or QoL scores), the mean difference (MD) was calculated. If different scales were adopted for the same outcome, the standardized mean difference (SMD) was used for analysis.

Both dichotomous and categorical outcomes were expressed with 95\% confidence intervals (CIs). 


\section{Unit of analysis issues}

Cluster-randomized trials were excluded from the meta-analysis as they are in general more prone to bias and, in the context of meta-analysis, they may cause overestimation of the effect of interventions due to the tendency to show narrow CIs and smaller P values (Chapter 16.3.1, Higgins 2011).

Cross-over trials were planned to be incorporated in meta-analyses by including only data from the very first period of randomized treatment (for continuous outcomes). In addition, cross-over trials were planned to be assessed for risk of bias by analyzing the following items in the report and the protocol of the study.

1. Was use of a cross-over design appropriate?

2. Is it clear that the order of receiving treatments was randomized?

3. Can it be assumed that the trial was not biased from carryover effects?

4. Are unbiased data available?

5. Are results of the second treatment period concealed?

If multiple treatments were compared within a single study, indirect comparisons were planned to be performed to provide an indirect estimate of the relative effect of the single interventions. The limits of this approach were taken into account during evaluation of the quality of evidence, according to GRADE criteria (Guyatt 2008).

\section{Dealing with missing data}

\section{Missing studies}

The comprehensive search strategy described above has been designed to minimize missing studies.

\section{Missing outcomes}

Studies not reporting information on a primary outcome were not excluded from the present systematic review. The lack of relevant outcomes from a study of interest was addressed in the discussion section and during 'Risk of bias' assessment.

\section{Missing data or missing individuals}

We attempted to request relevant missing data from the original authors or trialists. If data were apparently missing at random, we analyzed only the available information.

Because imputation strategies may significantly increase heterogeneity, we limited our analysis to participants for whom outcomes were obtained (available case analysis).

A high risk of selective reporting bias was assigned to trials when study outcomes were described in the methods paragraph but were not reported in the results section of the same article.

\section{Assessment of heterogeneity}

Evidence of heterogeneity was initially assessed by visual inspection of the forest plots. Heterogeneity was analyzed by calculating the $\mathrm{I}^{2}$ statistic. A $50 \%$ threshold was set for further investigation of heterogeneity by subgroup analysis.

Combined endpoints (for example, 'any adverse effects', including different lists of adverse effects for each trial) were assessed by the random-effects model.

\section{Assessment of reporting biases}

To identify reporting biases, we performed a comprehensive search of clinical trials registers (http://clinicaltrials.gov/; www.controlled-trials.com) in order to compare the original protocols with published reports of the same trials. Reporting bias was assessed by generating funnel plots in RevMan 5.1 and by testing for funnel plot asymmetry (for example, Egger test). These tests were planned to be performed if at least 10 studies were included in the meta-analysis.

\section{Data synthesis}

We compared dichotomous as well as non-dichotomous outcomes at the endpoint. We assessed effect size inconsistency as well as clinical study design and statistical heterogeneity.

We used a fixed-effect model to compare microbiological efficacy as standardized pathogen cultures performed on patients' biological samples evaluate exactly the same effect, and variations in this case are likely to be due to sampling issues. Conversely, a randomeffects model was adopted to evaluate clinical efficacy, to take into account the diverse strategies used in the included studies in order to assess general clinical endpoints (for example, cure or improvement definitions). Adverse effects were also analyzed using a random-effects model. Finally, data analyzed with a fixed-effect model were analyzed using a random-effects model to investigate heterogeneity among studies.

We reported non-dichotomous clinical outcomes (for example, questionnaire scores) by comparing the SMDs. We were aware that a limitation to this kind of analysis is the fact that the scores of clinical questionnaires are often based on ordinal scales.

For both continuous and dichotomous outcomes we calculated 95\% CIs.

Relevant data from pooled analyses were reported in 'Summary of findings' tables.

\section{Subgroup analysis and investigation of heterogeneity}

Where substantial heterogeneity was found among pooled studies evaluated with a fixed-effect model, we repeated the analysis using a random-effects model.

To explore possible sources of heterogeneity, we planned to perform subgroup analysis if an adequate number of pooled studies 
were available. Heterogeneity among study participants might be related to the following criteria:

1. age of participants ( $<55$ years versus $\geq 55$ years) (Berges 2011);

2. prostate volume $(<25 \mathrm{~mL}$ versus $\geq 25 \mathrm{~mL}$ ) (Berges 2011);

3. severity of symptoms at baseline or on study enrolment (assessed with National Institutes of Health Chronic Prostatitis Symptom Index (NIH-CPSI) or other symptom scores, bother scores, QoL scores, or patient self-declared status) (e.g., NIH-

CPSI total score $<15$ versus $\geq 15$ ) (Nickel 2001);

4. type, sensitivity or specificity of microbiological diagnostic tests (4-glass versus 2-glass);

5. previous antibacterial treatment (naïve versus heavily or chronically pretreated participants);

6. duration of antibacterial treatment $(<4$ weeks versus $\geq 4$ weeks);

7. duration of follow up ( $<1$ month versus $\geq 1$ month);

8. different criteria for microbiological outcome (e.g.,

different bacterial load cutoff to define pathogen eradication, for example, $10^{5}$ versus $10^{3} \mathrm{CFU} / \mathrm{mL}$ );

9. different tests used to measure clinical outcomes (e.g., NIHCPSI versus International Prostate Symptom Score (IPSS)).

Subgroup analysis was performed only in the presence of an adequate number of studies and if subgroup data were available.

\section{Sensitivity analysis}

Sensitivity analysis was used to explore the robustness of the metaanalysis in the presence of $\mathrm{I}^{2}$ values beyond the $50 \%$ threshold.

We performed sensitivity analysis in the presence of a sufficient number of included studies by repeating the analysis taking into account one or more of the following items:
1. specific parameters of study quality (e.g., low versus moderate or high risk of bias);

2. different measures of effect size (secondary analysis performed with odds ratios (ORs) in the case of the primary analysis performed using RRs);

3. different statistical models (secondary analysis performed with a random-effects model in the case of the primary analysis performed using a fixed-effect model).

\section{R E S U L T S}

\section{Description of studies}

See: Characteristics of included studies; Characteristics of excluded studies.

\section{Results of the search}

We identified 3394 potential studies from the article databases and 12 potential studies from the online congress abstract databases. The databases searched and the number of retrieved articles for each database are listed in Figure 1. From 104 potentially relevant studies selected after title and abstract review, 12 articles were not evaluable and 41 articles were excluded. Among the excluded papers, four did not involve antibacterial treatment, 26 were nonRCT studies, and 11 did not include patients with CBP or included patients showing CBP together with other concomitant conditions. Among the remaining 51 articles, 18 were finally included in this systematic review, 32 were excluded, and one awaits classification (Drasa 2009). 
Figure I. Flow chart of included and excluded studies.

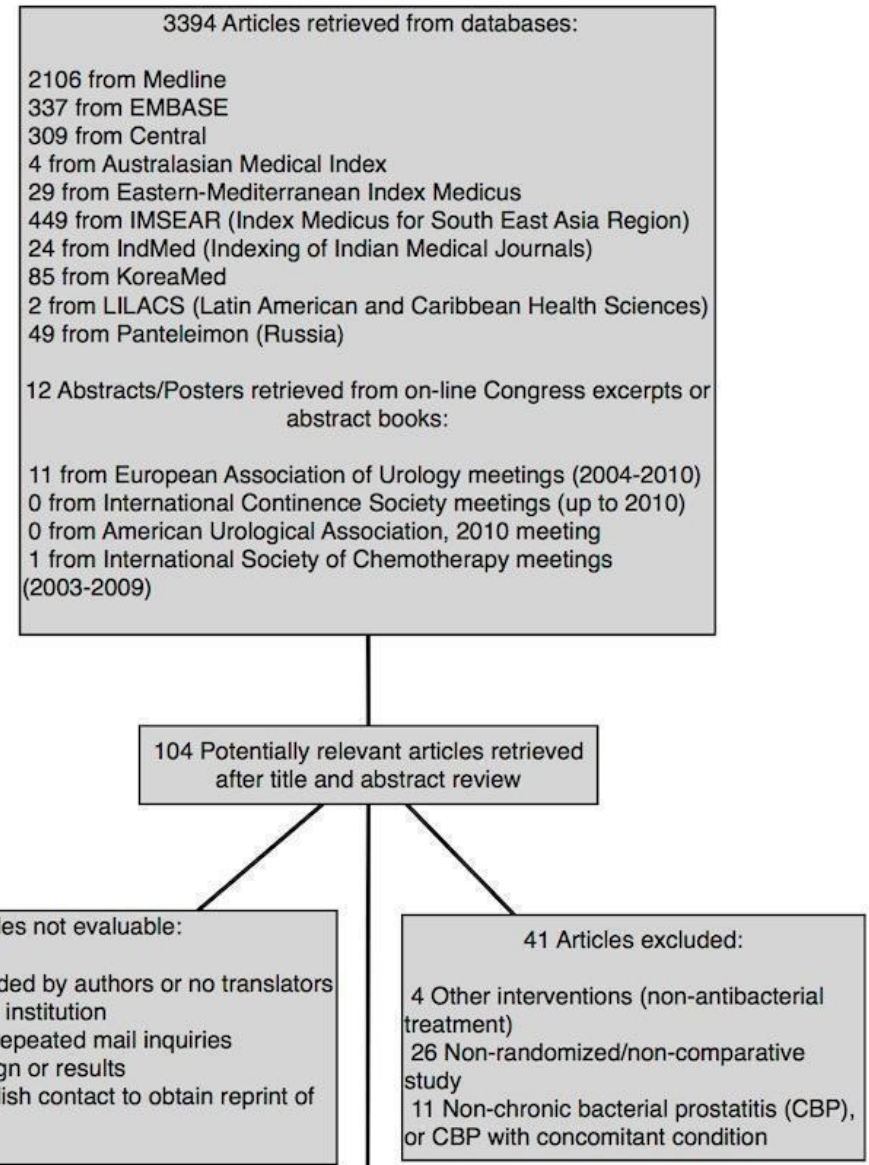

1 No translation provided by authors or no translator available at reviewer's institution

6 Did not respond to repeated mail inquiries

concerning study design or results

5 Impossible to establish contact to obtain reprint of

the article

or CBP with concomitant condition

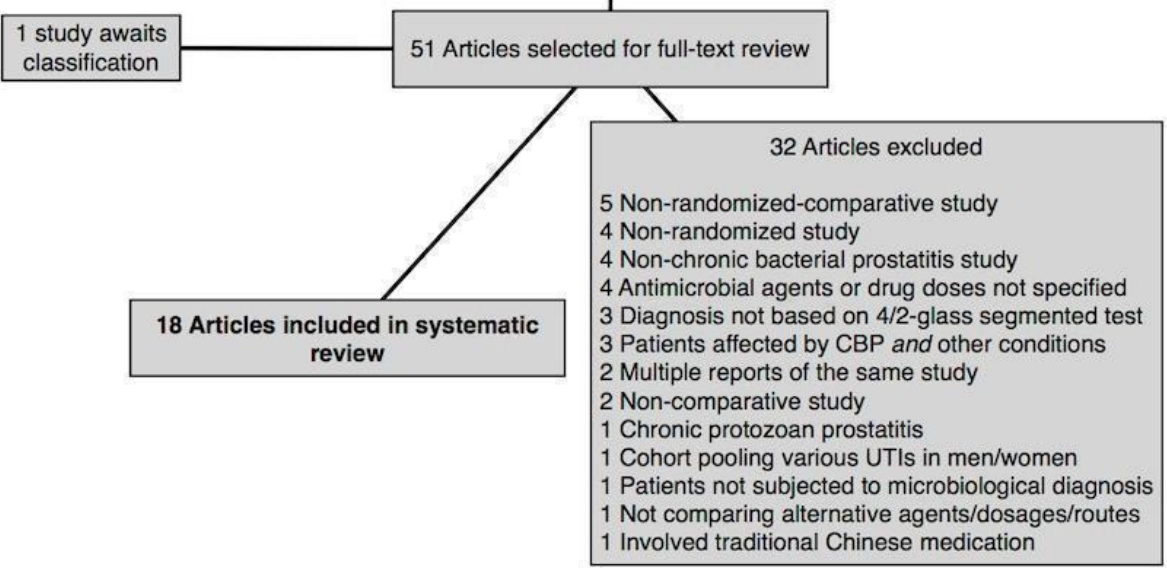

Antimicrobial therapy for chronic bacterial prostatitis (Review) 


\section{Included studies}

Eighteen studies, including a total of 2196 randomized participants, met all inclusion criteria. Among these studies, 14 compared two different antibacterial agents (AAs) in treatment arms containing participants with CBP caused by different pathogens (Bundrick 2003; Bustillo 1997; Cox 1989; Giannarini 2007; Koff 1996; Naber 2002; Paulson 1986; Zhang 2012), or CBP caused by a single pathogen (Cai 2010; Ohkawa 1993; Skerk 2002; Skerk 2003; Skerk 2004a; Skerk 2006). One RCT compared an AA with an AA combined with a phosphodiesterase-5 inhibitor (PDE5I) (Aliaev 2008). Two RCTs compared two courses of different lengths with the same AA (Skerk 2004b; Smith 1979). One article compared the combination of an AA plus herbal supplement with an AA administered as single-agent (Cai 2009).

\section{Excluded studies}

Thirty-two studies did not meet inclusion criteria. Two articles (Nickel 2008a; Schaeffer 2005) presented subset analyses of an included study (Bundrick 2003). Four articles were not focusing on CBP (Gleckman 1979; Martino 1993; Sabbaj 1986; Shen 2004), and one included participants with chronic prostatitis involving protozoans as the etiological agents (Vickovic 2010). One study included CBP patients $(n=2)$ within a treatment arm containing men and women with various urinary tract infections (Childs 1983). Two studies were non-comparative (Baert 1983; Wedren 1989), four were non-randomized (Brannan 1975; Colleen 1975; Kozdoba 2007; Smelov 2004), and five were non-RCTs (Cox
1991; Kunishima 2008; Lee 2006; Panagopoulos 2009; Shafik 1992). In particular, in the study by Lee et al, participants affected by category II and IIIa prostatitis were pooled together (Lee 2006). In three studies, participants were affected by CBP associated with other conditions, namely, vesiculitis (Kim 2006), urethritis (Zhang 2004), and genital infection with oligoasthenoteratozoospermia (Cai 2011). In three articles, a lower urinary tract segmented test was not mentioned or described in the methods section (Deng 2004; Hu 2002; Vicari 2000). In one study, a microbiological diagnostic test was not required at enrolment, and a past history of CBP was deemed sufficient to qualify a patient as having CBP (Paglia 2010). In four studies, participants belonging to a single treatment arm were treated with various antibiotics, and the names of the drugs or the number of participants treated with a given drug were not specified, or subgroup analysis was not performed (Ateya 2006; Barbalias 1998; Liao 2004; Trapeznikova 2007). For one (Chinese) study, translation was not available at the review authors' institutions, and was not provided by the authors when requested (Xu 2010). Moreover, this study, together with the Zhang 2004 and Liao 2004 trials, involved traditional Chinese medications. One RCT compared two different techniques of intraprostatic administration of AA. Thus, this was a trial evaluating neither alternative antibiotics, different doses or dosages, nor different routes of administration (Yavaçaoğ lu 1998).

\section{Risk of bias in included studies}

The risk of bias analysis is summarized in Figure 2 and Figure 3.

Figure 2. Risk of bias graph: review authors' judgements about each risk of bias item presented as percentages across all included studies.

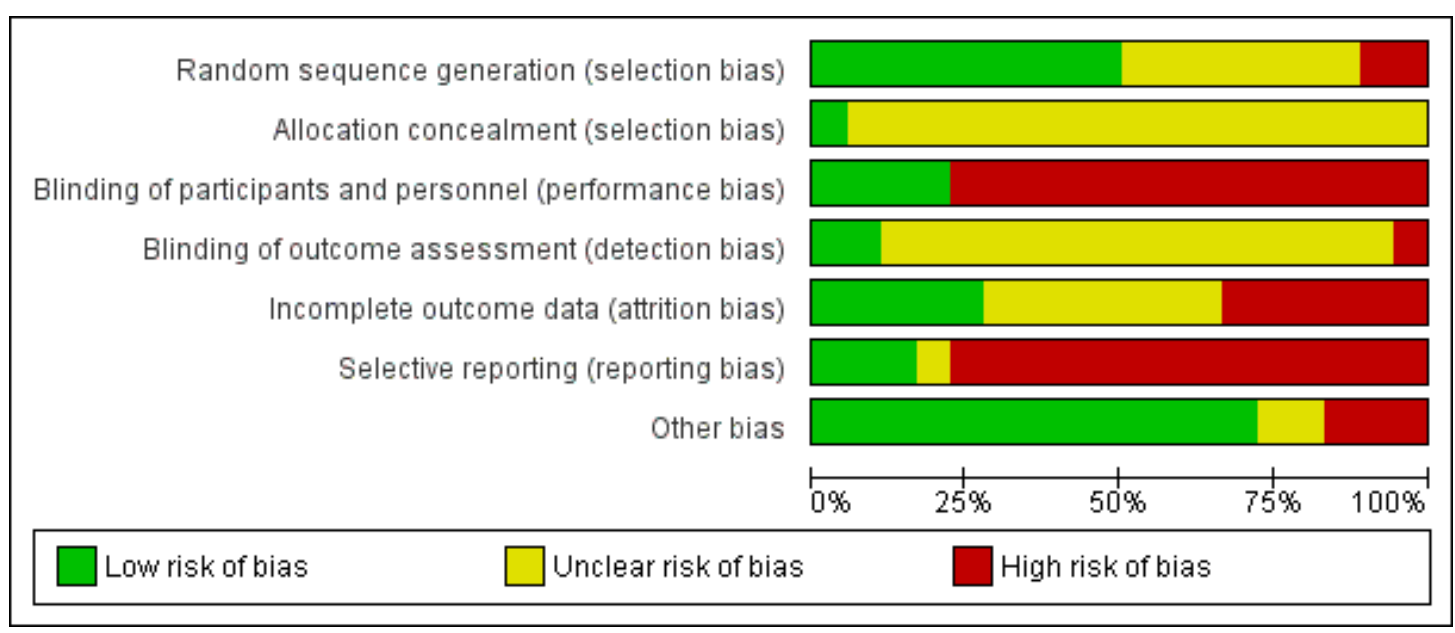

Antimicrobial therapy for chronic bacterial prostatitis (Review) 
Figure 3. Risk of bias summary: review authors' judgements about each risk of bias item for each included study.

\begin{tabular}{|c|c|c|c|c|c|c|c|}
\hline & 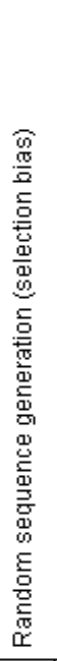 & 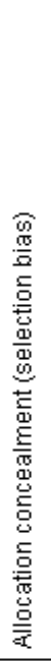 & 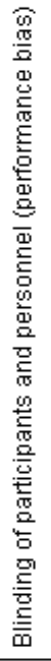 & 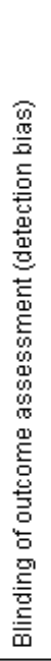 & 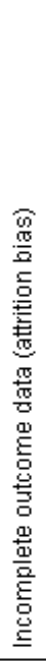 & 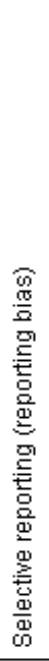 & 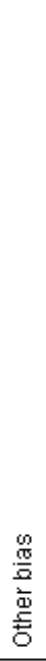 \\
\hline Aliaev 2008 & $?$ & $?$ & - & - & $?$ & - & $?$ \\
\hline Bundrick 2003 & $\odot$ & $?$ & + & $?$ & + & - & + \\
\hline Bustillo 1997 & - & $?$ & $\odot$ & $?$ & + & + & + \\
\hline Cai 2009 & $?$ & $?$ & - & $?$ & - & - & + \\
\hline Cai 2010 & $?$ & $?$ & $\odot$ & $?$ & + & + & + \\
\hline Cox 1989 & ? & $?$ & - & $?$ & $\odot$ & & \\
\hline Giannarini 2007 & + & + & $\odot$ & + & + & & + \\
\hline Koff 1996 & - & $?$ & + & $?$ & ? & & ? \\
\hline Naber 2002 & $\odot$ & $?$ & - & $?$ & + & + & + \\
\hline Ohkawa 1993 & $?$ & $?$ & C & ? & - & & + \\
\hline Paulson 1986 & ? & $?$ & & $?$ & - & & \\
\hline Skerk 2002 & + & $?$ & - & $?$ & ? & & + \\
\hline Skerk 2003 & + & $?$ & A & $?$ & $?$ & - & + \\
\hline Skerk 2004a & $\odot$ & $?$ & A & ? & ? & - & + \\
\hline Skerk 2004b & + & $?$ & ก & $?$ & $?$ & - & + \\
\hline Skerk 2006 & + & $?$ & - & $?$ & ? & - & + \\
\hline Smith 1979 & $?$ & $?$ & $\odot$ & + & - & $?$ & + \\
\hline Zhang 2012 & + & $?$ & - & $?$ & & & \\
\hline
\end{tabular}




\section{Allocation}

\section{Random sequence generation}

Nine trials described adequately the procedure used for generation of the randomization sequences (Bundrick 2003; Giannarini 2007; Naber 2002; Skerk 2002; Skerk 2003; Skerk 2004a; Skerk 2004b; Skerk 2006; Zhang 2012). In seven reports (Aliaev 2008; Cai 2009; Cai 2010; Cox 1989; Ohkawa 1993; Paulson 1986; Smith 1979), randomization procedures were not described in detail, though it was clearly stated that participants were randomized. In two studies, the sequence generation procedure was not adequate (Koff 1996) or not disclosed (Bustillo 1997).

\begin{abstract}
Allocation concealment
Allocation concealment procedures were not disclosed in all 18 included studies. Though concealment was probably adequate in one study (Giannarini 2007), in the remaining 17 studies it was unclear as to whether allocation was concealed or not (Aliaev 2008; Bundrick 2003; Bustillo 1997; Cai 2009; Cai 2010; Cox 1989; Koff 1996; Naber 2002; Ohkawa 1993; Paulson 1986; Skerk 2002; Skerk 2003; Skerk 2004a; Skerk 2004b; Skerk 2006; Smith 1979; Zhang 2012).
\end{abstract}

\section{Blinding}

Three studies were double-blinded (Bundrick 2003; Giannarini 2007; Smith 1979). One study was single-blinded (Paulson 1986). The remaining 14 studies were open-label (Aliaev 2008; Bustillo 1997; Cai 2009; Cai 2010; Cox 1989; Koff 1996; Naber 2002; Ohkawa 1993; Skerk 2002; Skerk 2003; Skerk 2004a; Skerk 2004b; Skerk 2006; Zhang 2012).

Lack of blinding was not deemed to be a major determinant of performance bias in one study having as the sole primary outcome a non-subjective endpoint, namely microbiological eradication (Koff 1996). Similarly, in the Smith paper (Smith 1979) the sole outcome of the trial was not subjective (microbiological eradication following antibiotic treatment), and the risk of both performance and detection biases was deemed to be low. On the contrary, primary outcomes based on clinical signs and symptoms or QoL scores (Aliaev 2008; Bustillo 1997; Cai 2009; Cai 2010; Cox 1989; Naber 2002; Ohkawa 1993; Skerk 2002; Skerk 2003; Skerk 2004a; Skerk 2004b; Skerk 2006; Zhang 2012) were considered at risk of bias in the absence of blinding.

The Paulson study (Paulson 1986) was deemed to be at high risk of bias. Although the study was single-blinded, participants in group 1 (oral minocycline twice daily) did not receive two additional placebo tablets to equal participants in group 2 (cephalexin four times/day).
The risk of detection bias was considered unclear if the blinding of outcome assessors was not described or disclosed in the study reports (Bundrick 2003; Bustillo 1997; Cai 2009; Cai 2010; Cox 1989; Koff 1996; Naber 2002; Ohkawa 1993; Paulson 1986; Skerk 2002; Skerk 2003; Skerk 2004a; Skerk 2004b; Skerk 2006; Zhang 2012). One open study was at high risk of bias due to the specific nature of the experimental drug combination (Aliaev 2008).

\section{Incomplete outcome data}

Two studies included an intention-to-treat (ITT) analysis ( Bundrick 2003; Naber 2002). Three studies (Bustillo 1997; Cai 2010; Giannarini 2007) were considered as having low risk of attrition bias due to the low impact of missing data on microbiological outcome estimates and the high expected frequency of the outcome (pathogen eradication after fluoroquinolone therapy). In seven studies, withdrawals and dropouts were not described or were indefinite; the risk of attrition bias was unclear in these studies (Aliaev 2008; Koff 1996; Skerk 2002; Skerk 2003; Skerk 2004a; Skerk 2004b; Skerk 2006). In one study, the risk of bias was high due to the high rate of withdrawals $(22.2 \%$ per treatment arm) (Ohkawa 1993). Two studies were considered at high risk of attrition bias as the reasons for study withdrawals were not presented separately according to treatment group (Cai 2009) or to disease group (Paulson 1986). One study showed high dropout frequencies in both treatment arms (59\% and 41.6\%) but lacked an ITT analysis (Cox 1989). This study was considered as having a high risk of bias. Similarly, in the Smith study (Smith 1979) a high number of withdrawals in the treatment groups and the low expected therapeutic success of the experimental drug (co-trimoxazole) suggested high attrition bias. In the Zhang 2012 study, almost $40 \%$ of the isolated pathogen strains were resistant to ciprofloxacin. Nevertheless, patients harbouring resistant strains were apparently treated with ciprofloxacin. Subgroup analysis on eradication rates only in patients harboring sensitive strains was not disclosed.

\section{Selective reporting}

Three trials were considered to be free of selective reporting (Bustillo 1997; Cai 2010; Naber 2002). In the Smith paper, a section addressing clinical results was not presented although clinical assessments were described in the methods section (Smith 1979). Fourteen trials were considered at high risk of reporting bias (Aliaev 2008; Bundrick 2003; Cai 2009; Cox 1989; Giannarini 2007; Koff 1996; Ohkawa 1993; Paulson 1986; Skerk 2002; Skerk 2003; Skerk 2004a; Skerk 2004b; Skerk 2006; Zhang 2012). 


\section{Other potential sources of bias}

In one study, the per protocol-like design did not allow evaluating the presence or absence of baseline imbalances (Aliaev 2008). Risk of bias was unclear. In one high-risk trial, patients with different urological conditions were pooled at enrolment (Paulson 1986). This made evaluating baseline values impossible. In one study, the trial design and methods were not described in sufficient detail (Koff 1996), and risk of bias was rated 'unclear'. One high risk of bias study was poorly designed as participants with acute prostatitis were included in a cohort of CBP participants (Cox 1989). In one high-risk study, 'additional agents' were administered to a fraction of the participants in both treatment arms; names and dosages of these agents were not disclosed (Zhang 2012). Moreover, the design of the 4-glass lower urinary tract diagnostic segmented test was modified, and assessment of concomitant bacterial urethritis was impossible (Zhang 2012). In the same study, resistance to study drugs was not an exclusion criterion. In the remaining studies, risk of bias was considered low (Bundrick 2003; Bustillo 1997; Cai 2009; Cai 2010; Giannarini 2007; Naber 2002; Ohkawa 1993; Skerk 2002; Skerk 2003; Skerk 2004a; Skerk 2004b; Skerk 2006; Smith 1979).

\section{Effects of interventions}

See: Summary of findings for the main comparison Levofloxacin versus ciprofloxacin for chronic bacterial prostatitis; Summary of findings 2 Lomefloxacin versus comparator fluoroquinolone for chronic bacterial prostatitis; Summary of findings 3 Ciprofloxacin versus comparator fluoroquinolone for chronic bacterial prostatitis; Summary of findings 4 Levofloxacin versus comparator fluoroquinolone for chronic bacterial prostatitis Eighteen RCTs were included in this review.

\section{Different antibacterial agents}

Fourteen parallel-group studies compared different antibacterial agents.

\section{Comparisons between different fluoroquinolones}

\section{Levofloxacin versus ciprofloxacin}

Two studies, involving a total of 791 participants (Bundrick 2003, 383 participants; Zhang 2012, 408 participants), compared levofloxacin (500 mg once daily for four weeks in both trials) to ciprofloxacin (500 mg twice daily for four weeks in both trials) in patients affected by CBP (Summary of findings for the main comparison). The Bundrick study was double-blind, whereas the Zhang study was open-label. Both studies included an ITT analysis. The studies had similar microbiological and clinical outcomes (microbiological eradication at the end of therapy; clinical success (cured or improved) at the end of therapy and after a six-month follow-up; adverse effects of treatment).

- Microbiological efficacy (pathogen eradication) did not differ significantly between groups in the Bundrick study (RR $0.98,95 \%$ CI 0.85 to 1.12 ), whereas in the Zhang study levofloxacin was found to significantly increase the RR for microbiological eradication (RR 1.42 , 95\% CI 1.25 to 1.61 ) (Analysis 1.1). When data were pooled (levofloxacin versus ciprofloxacin comparison), a significant increase in RR for eradication was observed (RR 1.22, 95\% CI 1.11 to 1.34 , fixedeffect model). Substantial heterogeneity was found between the studies $\left(\mathrm{Chi}^{2}=15.82(\mathrm{P}<0.0001) ; \mathrm{I}^{2}=94 \%\right)$. When a randomeffects model was adopted to analyze the pooled eradication data, the difference lost statistical significance (RR 1.18, 95\% CI 0.81 to 1.71 ) (Analysis 1.2). Sensitivity analysis was performed by calculating ORs in place of RRs for the microbiological efficacy primary outcome. Results from the Bundrick study were not substantially affected (OR $0.91,95 \%$ CI 0.51 to 1.60 (fixedeffect and random-effects models; forest plot not shown)). Conversely, results from the Zhang study were substantially influenced by this strategy (OR 3.99, 95\% CI 2.43 to 6.35 (fixed-effect model); OR 3.93, 95\% CI 2.43 to 6.35 (randomeffects model; forest plot not shown)). Consequently, pooled results were also affected (OR 2.16, 95\% CI 1.52 to 3.07 (fixedeffect model); OR 1.90, 95\% CI 0.45 to 8.01 (random-effects model; forest plot not shown)).

- In the Bundrick study, clinical efficacy (cure or improvement) did not differ significantly between groups when assessed at the end of therapy (RR $1.03,95 \%$ CI 0.89 to 1.19 ) or after a six-month follow-up (RR $0.99,95 \%$ CI 0.85 to 1.16 ) (Analysis 1.3). In the Zhang study, levofloxacin was found to significantly increase the RR for clinical efficacy (cure or improvement) both at the end of therapy (RR 1.30, 95\% CI 1.18 to 1.43 ) and at follow-up (RR $1.33,95 \%$ CI 1.21 to 1.46 ). When data were pooled, clinical efficacy did not differ significantly between treatment arms, both at the end of therapy (RR 1.16, 95\% CI 0.93 to 1.46) and at follow-up (RR 1.16, 95\% CI 0.86 to 1.55 ) (Analysis 1.3 ). Also in this case significant heterogeneity was observed between the studies (end of therapy: $\mathrm{Chi}^{2}=7.06(\mathrm{P}=0.008) ; \mathrm{I}^{2}=86 \%$; follow-up: $\mathrm{Chi}^{2}=10.35(\mathrm{P}=$ $\left.0.001) ; \mathrm{I}^{2}=90 \%\right)$. Sensitivity analysis was performed by calculating ORs in place of RRs for clinical efficacy (forest plots not shown). Results from the Bundrick study were not substantially affected (OR 1.12, 95\% CI 0.64 to 1.95 (end of therapy); OR $0.97,95 \%$ CI 0.57 to 1.66 (follow-up)). Results from the Zhang study were substantially influenced by this strategy (OR 5.45, 95\% CI 2.92 to 10.18 (end of therapy); OR $6.75,95 \%$ CI 3.50 to 13.04 (follow-up)). Consequently, pooled results were also affected (OR 2.46, 95\% CI 0.52 to 11.63 (end of therapy); OR 2.54, 95\% CI 0.38 to 17.14 (follow-up)).

- The rate of adverse effects did not differ significantly between treatment groups in both studies (Analysis 1.4). With 
the exception of the 'dizziness' effect $\left(\mathrm{Chi}^{2}=3.68(\mathrm{P}=0.06)\right.$; $\mathrm{I}^{2}$ $=73 \%$ ), heterogeneity was not detected for the adverse effects of treatment outcome.

\section{Prulifloxacin versus levofloxacin}

In one study involving 96 participants (Giannarini 2007), prulifloxacin (600 mg once daily for four weeks) was compared to levofloxacin (500 mg once daily for four weeks).

- Microbiological efficacy (pathogen eradication) did not differ significantly between groups (RR 1.02, 95\% CI 0.79 to 1.33) (Analysis 2.1).

- Clinical efficacy (total NIH-CPSI scores) did not differ significantly between groups when assessed at the end of therapy (SMD -0.03, 95\% CI -0.45 to 0.39) (Analysis 2.2).

- The rate of adverse effects did not differ significantly between treatment groups (RR 0.82, 95\% CI 0.36 to 1.88 (any adverse effects)) (Analysis 2.3).

\section{Lomefloxacin versus ofloxacin}

In one study involving 33 participants (Koff 1996), lomefloxacin (400 mg once daily for six weeks) was compared to ofloxacin (200 mg twice daily for six weeks).

- Microbiological efficacy (pathogen eradication) after a sixmonth follow-up did not differ significantly between groups (RR $1.11,95 \%$ CI 0.66 to 1.88 ) (Analysis 3.1).

- The rate of adverse effects did not differ significantly between the treatment groups (RR 0.42, 95\% CI 0.16 to 1.12 (any adverse effects)) (Analysis 3.2).

\section{Lomefloxacin versus ciprofloxacin}

In one study involving 182 participants (Naber 2002) lomefloxacin (400 mg once daily for four weeks) was compared to ciprofloxacin (500 mg twice daily for four weeks). In this study, equivalence between lomefloxacin and ciprofloxacin was defined as a $95 \%$ CI within $15 \%$ of the observed differences.

\section{Intention-to-treat (ITT) analysis}

- Microbiological efficacy (pathogen eradication) did not differ significantly between groups at the end of therapy (RR $0.96,95 \%$ CI 0.82 to 1.11 ) or for follow-up at four weeks (RR $0.87,95 \%$ CI 0.72 to 1.06 ), three months (RR $0.90,95 \%$ CI 0.74 to 1.09 ) or six months (RR $0.87,95 \%$ CI 0.67 to 1.12 ) (Analysis 4.1).

- Clinical efficacy (cure or improvement) did not differ significantly between groups when assessed at the end of therapy (RR 1.01, 95\% CI 0.94 to 1.09 ) or for follow-up at four weeks (RR 0.91, 95\% CI 0.78 to 1.05 ), three months (RR 0.97, 95\%
CI 0.82 to 1.15 ) or six months (RR $0.91,95 \%$ CI 0.75 to 1.11 ) (Analysis 4.3).

- The rate of adverse effects did not differ significantly between treatment groups (RR 0.82, 95\% CI 0.40 to 1.68 (any adverse effects)) (Analysis 4.5).

\section{Per protocol analysis}

- Microbiological efficacy (pathogen eradication) did not differ significantly between groups at the end of therapy (RR $0.98,95 \%$ CI 0.89 to 1.09 ) or for follow-up at four weeks (RR $1.00,95 \%$ CI 0.94 to 1.07 ), three months (RR $1.03,95 \% \mathrm{CI}$ 0.94 to 1.12 ) or six months (RR $0.94,95 \%$ CI 0.80 to 1.09 ) (Analysis 4.2).

- Clinical efficacy (cure or improvement) did not differ significantly between groups when assessed at the end of therapy (RR $0.96,95 \%$ CI 0.89 to 1.03 ) or for follow-up at four weeks (RR $1.00,95 \%$ CI 0.86 to 1.18), three months (RR 1.07, 95\% CI 0.94 to 1.21 ) or six months (RR $0.88,95 \%$ CI 0.77 to 1.01 ) (Analysis 4.4).

\section{Lomefloxacin versus comparator fluoroquinolone}

Two trials (Koff 1996; Naber 2002) compared a cycle of treatment with lomefloxacin (400 mg once daily) with a comparator secondgeneration fluoroquinolone (Koff 1996: ofloxacin; Naber 2002: ciprofloxacin) (Summary of findings 2).

- The trials were pooled for microbiological efficacy (pathogen eradication) at follow-up (six months). The RR analysis showed no significant difference between the treatment arms (RR 0.96, 95\% CI 0.80 to 1.16) (Analysis 5.1).

- The trials were also pooled for adverse effects. Men in the lomefloxacin arm were not at a significantly different risk than men in the comparator fluoroquinolone arm for total adverse effects (RR $0.64,95 \%$ CI 0.34 to 1.21 ), gastrointestinal effects (RR $0.58,95 \%$ CI 0.27 to 1.23 ), headache (RR 0.56, 95\% CI 0.07 to 4.43 ) or dizziness (RR $0.88,95 \%$ CI 0.09 to 8.60 ) (Analysis 5.2). Heterogeneity was not detected for the adverse effects outcome.

\section{Ciprofloxacin versus comparator fluoroquinolone}

Three trials (Bundrick 2003; Naber 2002; Zhang 2012) compared a cycle of treatment with ciprofloxacin $(500 \mathrm{mg}$ twice daily for four weeks) with a comparator second-generation fluoroquinolone (Bundrick 2003 and Zhang 2012: levofloxacin 500 mg once daily for four weeks; Naber 2002: lomefloxacin $400 \mathrm{mg}$ once daily for four weeks) (Summary of findings 3).

- When microbiological efficacy outcome data were pooled, the RR for pathogen eradication was 0.87 (95\% CI 0.80 to 0.94 ) (Analysis 6.1, fixed-effect model). Substantial heterogeneity was found between the studies $\left(\mathrm{Chi}^{2}=22.32(\mathrm{P}\right.$ value $<0.0001) ; \mathrm{I}^{2}=$ 
91\%). When a random-effects model was adopted to further analyze the pooled eradication data, the difference lost statistical significance (RR 0.91, 95\% CI 0.70 to 1.18) (Analysis 6.2). When the Zhang study (identified as the likely source of heterogeneity by visual inspection of the forest plot) was excluded from the pooled analysis, the $\mathrm{I}^{2}$ value changed from $91 \%$ to $0 \%$ and the RR for a random-effects model was 1.03 (95\% CI 0.93 to 1.14 ) (Analysis 6.2). Sensitivity analysis was performed by calculating ORs in place of RRs for the microbiological efficacy outcome. The OR for pathogen eradication for a fixed-effect model was 0.56 (95\% CI 0.41 to 0.77) ( $\mathrm{I}^{2}=90 \%$; forest plot not shown). The OR for pathogen eradication for a random-effects model was 0.69 (95\% CI 0.24 to 2.02$)$ ( $\mathrm{I}^{2}=90 \%$; forest plot not shown). When the Zhang study was excluded from the pooled studies, the $\mathrm{I}^{2}$ value changed from $90 \%$ to $0 \%$ and the OR for a random-effects model was 1.15 (95\% CI 0.74 to 1.80 ; forest plot not shown).

- When clinical efficacy (cure or improvement) data were pooled, results did not differ significantly between treatment arms, both at the end of therapy (RR $0.90,95 \%$ CI 0.75 to 1.08 ) and at follow-up (RR $0.93,95 \%$ CI 0.72 to 1.20 ). Also in this case significant heterogeneity was observed between the studies (end of therapy: $\mathrm{Chi}^{2}=19.30$ (P value < 0.0001); $\mathrm{I}^{2}=$ 90\%; follow-up: $\mathrm{Chi}^{2}=18.31(\mathrm{P}$ value $\left.=0.0001) ; \mathrm{I}^{2}=89 \%\right)$ (Analysis 6.3). Exclusion of the Zhang study reduced the $\mathrm{I}^{2}$ value to $0 \%$. Sensitivity analysis was performed by calculating ORs in place of RRs for the clinical efficacy primary outcome. The OR for clinical efficacy at the end of therapy for a random-effects model was 0.49 (95\% CI 0.15 to 1.56$)\left(\mathrm{I}^{2}=86 \%\right.$; forest plot not shown). The OR for clinical efficacy at follow-up with a random-effects model was 0.59 (95\% CI 0.16 to 2.18$)\left(\mathrm{I}^{2}=\right.$ 93\%; forest plot not shown). Exclusion of the Zhang study reduced the $\mathrm{I}^{2}$ value to $0 \%$.

- The rate of adverse effects did not differ significantly between treatment groups in both studies (Analysis 6.4) and, when feasible, in pooled analyses. Heterogeneity was not detected for the adverse effects outcome.

\section{Levofloxacin versus comparator fluoroquinolone}

Three trials (Bundrick 2003; Giannarini 2007; Zhang 2012) compared a cycle of treatment with levofloxacin (500 mg once daily for four weeks) with a comparator fluoroquinolone (Bundrick 2003 and Zhang 2012: ciprofloxacin 500 mg twice daily for four weeks; Giannarini 2007: prulifloxacin $600 \mathrm{mg}$ once daily for four weeks) (Summary of findings 4).

- When microbiological efficacy outcome data were pooled, a significant increase in RR for pathogen eradication was observed (RR 1.19, 95\% CI 1.09 to 1.30, fixed-effect model) (Analysis 7.1). Substantial heterogeneity was found between the studies $\left(\mathrm{Chi}^{2}=17.85(\mathrm{P}\right.$ value $\left.=0.0001) ; \mathrm{I}^{2}=89 \%\right)$. When a randomeffects model was adopted to further analyze the pooled pathogen eradication data the difference lost statistical significance (RR 1.12, 95\% CI 0.84 to 1.48 ) (Analysis 7.2). When the Zhang study (identified as the likely source of heterogeneity by visual inspection of the forest plot) was excluded from the pooled analysis, the $\mathrm{I}^{2}$ value changed from $89 \%$ to $0 \%$ and the RR for the random-effects model was 0.98 (95\% CI 0.87 to 1.10 ) (Analysis 7.2$)$. Sensitivity analysis was performed by calculating ORs in place of RRs for the microbiological efficacy outcome. The OR for pathogen eradication with a fixed-effect model was 1.93 (95\% CI 1.39 to 2.68) ( $\mathrm{I}^{2}=89 \%$; forest plot not shown). The OR for pathogen eradication with a random-effects model was 1.54 (95\% CI 0.52 to 4.52$)\left(I^{2}=89 \%\right.$; forest plot not shown). When the Zhang study was excluded from the pooled studies, the $\mathrm{I}^{2}$ value changed from $90 \%$ to $0 \%$ and the OR for the random-effects model was 0.91 (95\% CI 0.56 to 1.48 ; forest plot not shown).

- The rate of adverse effects did not differ significantly between treatment groups (Analysis 7.3). Heterogeneity was not detected for the adverse effects outcome.

\section{Fluoroquinolones versus other antibacterial agents}

\section{Prulifloxacin versus doxycycline}

In one study involving 221 participants (Cai 2010), prulifloxacin (600 mg once daily for two weeks) was compared to doxycycline (100 mg twice daily for three weeks) in patients affected by chlamydial prostatitis.

- Microbiological efficacy, evaluated as the absence of both chlamydial deoxyribonucleic acid (DNA) and anti-Chlamydia immunoglobulin A (IgA) at the end of therapy, did not differ significantly between groups (RR $1.12,95 \%$ CI 0.93 to 1.36 ) (Analysis 8.1).

- For clinical efficacy, a significant difference in the total NIH-CPSI scores was observed for the prulifloxacin and doxycycline comparison (SMD -0.66, 95\% CI -0.94 to -0.39) (Analysis 8.2).

- Clinical efficacy, defined as the fraction of asymptomatic patients at the end of therapy, did not differ significantly between treatment arms (RR 1.04, 95\% CI 0.91 to 1.19) (Analysis 8.3).

- The rate of adverse effects did not differ significantly between treatment groups (RR 1.17, 95\% CI 0.32 to 4.24 (any adverse effects)) (Analysis 8.4).

\section{Ofloxacin versus minocycline}

In one study involving 18 participants (Ohkawa 1993), ofloxacin (200 mg thrice daily for two weeks) was compared to minocycline (100 mg twice daily for two weeks) in patients affected by ureaplasmal prostatitis. 
- Microbiological efficacy (pathogen eradication) did not differ significantly between groups (RR $1.00,95 \%$ CI 0.78 to 1.29) (Analysis 9.1).

- Clinical efficacy (cure or improvement), assessed at the end of therapy, did not differ significantly between groups (RR 0.87 , 95\% CI 0.59 to 1.26 ) (Analysis 9.2).

- The trial authors reported that neither group was affected by adverse effects of therapy.

\section{Ofloxacin versus carbenicillin}

In one study involving 46 participants (Cox 1989), ofloxacin (300 mg twice daily for six weeks) was compared to carbenicillin (764 $\mathrm{mg}$ four times/day for six weeks).

- Microbiological efficacy (pathogen eradication) did not differ significantly between groups (RR 1.04, 95\% CI 0.76 to 1.42) (Analysis 10.1).

- Clinical efficacy (cure or improvement), assessed at the end of treatment, did not differ significantly between groups (RR $1.06,95 \%$ CI 0.85 to 1.32 ) (Analysis 10.2).

- The rate of adverse effects did not differ significantly between the treatment groups (RR 0.73, 95\% CI 0.31 to 1.71 (any adverse effects)) (Analysis 10.3).

\section{Lomefloxacin versus trimethoprim-sulfamethoxazole (co- trimoxazole)}

In one study involving 30 participants (Bustillo 1997), lomefloxacin ( $400 \mathrm{mg}$ once daily for six weeks) was compared to cotrimoxazole $(160+800 \mathrm{mg}$ twice daily for six weeks).

- Microbiological efficacy (pathogen eradication) did not differ significantly between the groups at the end of therapy (RR $1.09,95 \%$ CI 0.82 to 1.44 ) or at the end of a four-month follow-up (RR 1.09, 95\% CI 0.82 to 1.44 ) (Analysis 11.1).

- Clinical efficacy (cure or improvement) did not differ significantly between groups when assessed at the end of therapy (RR $1.00,95 \%$ CI 0.87 to 1.15 ) or at the end of a four-month follow-up (RR 1.00, 95\% CI 0.87 to 1.15) (Analysis 11.2).

- The rate of adverse effects did not differ significantly between treatment groups (RR 0.43, 95\% CI 0.04 to 4.25 (any adverse effects)) (Analysis 11.3).

\section{Ciprofloxacin versus azithromycin}

In one study involving 89 participants affected by chlamydial prostatitis (Skerk 2003), ciprofloxacin (500 mg twice daily for 20 days) was compared to azithromycin (500 mg once daily, thriceweekly (first three consecutive days of each week) for three weeks).

- There was a significant increase in pathogen eradication in the azithromycin arm (RR $0.48,95 \%$ CI 0.32 to 0.72 ) (Analysis 12.1).
- There was a significant increase in clinical success (cure or improvement) in the azithromycin arm (RR 0.64, 95\% CI 0.46 to 0.90) (Analysis 12.2).

- The rate of adverse effects did not differ significantly between the treatment groups (RR 0.34, 95\% CI 0.01 to 8.15 (any adverse effects)) (Analysis 12.3).

\section{Comparisons between different non-fluoroquinolone antibiotics}

\section{Minocycline versus cephalexin}

In one study involving 27 participants (Paulson 1986), minocycline (100 mg twice daily for four weeks) was compared to cephalexin (500 mg four times/day for four weeks).

- Microbiological efficacy (pathogen eradication and eradication plus superinfection) did not differ significantly between groups at the end of therapy (RR 1.70, 95\% CI 0.54 to 5.34) (Analysis 13.1).

- Microbiological recurrence rates did not differ significantly between groups at the end of therapy (RR $0.98,95 \%$ CI 0.37 to 2.59) (Analysis 13.3).

- Clinical efficacy (cure or improvement), assessed at the end of therapy, did not differ significantly between groups (RR 2.04, 95\% CI 0.83 to 4.99 ) (Analysis 13.2).

- Adverse effects of therapy were not reported.

\section{Azithromycin versus clarithromycin}

In one study involving 91 participants affected by chlamydial prostatitis (Skerk 2002), azithromycin (500 mg once daily, thrice weekly (first three consecutive days of each week) for three weeks) was compared to clarithromycin $(500 \mathrm{mg}$ twice daily for two weeks).

- Microbiological efficacy (pathogen eradication at the testof-cure (TOC) visit) did not differ significantly between groups (RR 1.01, 95\% CI 0.82 to 1.23) (Analysis 14.1).

- Clinical efficacy (cure rate) did not differ significantly between groups when assessed at the end of therapy (RR 0.98, 95\% CI 0.75 to 1.28 ) (Analysis 14.2).

- The rate of adverse effects did not differ significantly between the treatment groups (RR 1.96, 95\% CI 0.18 to 20.83 (any adverse effects)) (Analysis 14.3).

\section{Azithromycin versus doxycycline in chlamydial prostatitis}

In one study involving 125 participants affected by chlamydial prostatitis (Skerk 2004a), azithromycin (1000 mg once weekly for four weeks) was compared to doxycycline (100 mg twice daily for four weeks). 
- Microbiological efficacy (pathogen eradication at the end of therapy) did not differ significantly between groups (RR 1.03, 95\% CI 0.85 to 1.26 ) (Analysis 15.1).

- Clinical efficacy assessed as inflammatory findings at the end of therapy (number of participants with white blood cell counts in EPS/VB3 < 10 per high power field) did not differ significantly between groups (RR $1.08,95 \%$ CI 0.66 to 1.78 ) (Analysis 15.2).

- Clinical efficacy (cure or improvement) did not differ significantly between groups when assessed at the end of therapy (RR 0.95 , 95\% CI 0.76 to 1.19 ) (Analysis 15.2).

- The rate of adverse effects did not differ significantly between the treatment groups (RR 0.21, 95\% CI 0.04 to 1.04 (any adverse effects)) (Analysis 15.3).

\section{Azithromycin versus doxycycline in ureaplasmal prostatitis}

In one study involving 63 participants affected by ureaplasmal prostatitis (Skerk 2006), azithromycin (500 mg once daily, thrice weekly (first three consecutive days of each week) for three weeks) was compared to doxycycline (100 mg twice daily for three weeks).

- Microbiological efficacy (pathogen eradication at the end of therapy) did not differ significantly between groups (RR 1.05, 95\% CI 0.80 to 1.39 ) (Analysis 16.1).

- Clinical efficacy (cure) did not differ significantly between groups when assessed at the end of therapy (RR 1.01, 95\% CI 0.72 to 1.42 ) (Analysis 16.2).

- The rate of adverse effects did not differ significantly between the treatment groups (RR 0.09, 95\% CI 0.01 to 1.53 (any adverse effects)) (Analysis 16.3).

\section{Different duration of therapy courses for the same antibacterial agent}

\section{Azithromycin $4.5 \mathrm{~g}$ versus $6.0 \mathrm{~g}$ (total dose) in chlamydial prostatitis}

In one study focusing on chlamydial prostatitis (Skerk 2004b), 89 participants were randomly divided into a treatment arm receiving a total dose of $4.5 \mathrm{~g}$ azithromycin $(500 \mathrm{mg}$ once daily, thrice weekly (first three consecutive days of each week) for three weeks) and a treatment arm receiving total $6.0 \mathrm{~g}$ azithromycin (500 mg once daily, thrice weekly (first three consecutive days of each week) for four weeks).

- Microbiological efficacy (pathogen eradication at the end of therapy) did not differ significantly between groups (RR 0.99, 95\% CI 0.81 to 1.21 ) (Analysis 17.1).

- Clinical efficacy (cure) did not differ significantly between groups when assessed at the end of therapy (RR 0.96, 95\% CI 0.74 to 1.26 ) (Analysis 17.2).
- The rate of adverse effects did not differ significantly between treatment groups (RR 0.19, 95\% CI 0.01 to 3.79 (any adverse effects)) (Analysis 17.3).

\section{Co-trimoxazole $480 \mathrm{mg}$ twice daily for 12 weeks versus 10 days}

In one study involving 38 participants affected by chronic bacterial prostatitis (Smith 1979), oral co-trimoxazole (480 mg twice daily), administered for a period of 12 weeks, was compared to $480 \mathrm{mg}$ oral co-trimoxazole (400 mg sulfamethoxazole; $80 \mathrm{mg}$ trimethoprim), administered twice daily for 10 days.

- There was a significant increase in pathogen eradication in the 12 -week treatment arm (RR 3.00, 95\% CI 1.01 to 8.95 ) (Analysis 18.1).

- The rate of adverse effects did not differ significantly between the treatment groups (RR 0.53, 95\% CI 0.05 to 5.31 (any adverse effects)) (Analysis 18.2).

\section{Antibacterial agents combined with other medications or supplements}

Fluoroquinolone plus phosphodiesterase-5 inhibitors versus fluoroquinolone

In one study involving 103 participants divided into three treatment arms (Aliaev 2008), a combination of levofloxacin $(500 \mathrm{mg}$ once daily for four weeks) with vardenafil, administered at fixed daily doses (10 mg once daily) or on-demand (a single $10 \mathrm{mg}$ tablet), was compared with levofloxacin as single-agent (500 mg once daily for four weeks). The two regimens of combined therapy were also directly compared.

\section{Levofloxacin plus vardenafil at fixed daily dose versus levofloxacin}

- Microbiological efficacy (pathogen eradication at the end of therapy) did not differ significantly between groups (RR 1.04, 95\% CI 0.90 to 1.19) (Analysis 19.1).

- Clinical efficacy, assessed as NIH-CPSI pain, voiding and QoL impact scores, did not differ significantly between groups when assessed at the end of therapy (pain score: SMD - 0.13 , 95\% CI -0.62 to 0.35 ; voiding score: SMD $-0.30,95 \%$ CI -0.78 to 0.19 ; QoL impact score: SMD $-0.24,95 \% \mathrm{CI}-0.72$ to 0.25 ) (Analysis 19.2).

- Clinical efficacy, defined as improvement of inflammatory findings (number of participants with leukocytosis in postmassage urine specimens at the end of treatment), did not differ significantly between groups (RR $0.54,95 \%$ CI 0.17 to 1.66 ) (Analysis 19.3). 
- Clinical efficacy, expressed as urinary peak flow rates (Qmax, $\mathrm{mL} / \mathrm{s}$ ), did not differ significantly between treatment groups (SMD 0.24, 95\% CI -0.25 to 0.72) (Analysis 19.4).

\section{Levofloxacin plus vardenafil on-demand versus levofloxacin}

- Microbiological efficacy (pathogen eradication at the end of therapy) did not differ significantly between groups (RR 1.01, 95\% CI 0.88 to 1.17 ) (Analysis 20.1).

- NIH-CPSI pain and voiding scores did not differ significantly between groups when assessed at the end of therapy (pain score: SMD -0.06, 95\% CI - 0.53 to 0.42 ; voiding score: SMD $0.27,95 \%$ CI -0.20 to 0.75 ) (Analysis 20.2).

- The scores of the NIH-CPSI domain focusing on the impact of the disease on the QoL of participants differed between groups, in favor of treatment with levofloxacin alone (SMD 0.52, 95\% CI 0.04 to 1.01 ) (Analysis 20.2).

- Clinical efficacy, defined as improvement of inflammatory findings (number of participants with leukocytosis in postmassage urine specimens at the end of treatment), did not differ significantly between groups (RR $0.74,95 \%$ CI 0.28 to 1.98 ) (Analysis 20.3).

- Clinical efficacy, expressed as urinary peak flow rates (Qmax, mL/s), did not differ significantly between treatment groups (SMD 0.10, 95\% CI -0.37 to 0.57) (Analysis 20.4).

\section{Levofloxacin plus vardenafil at fixed daily dose versus levofloxacin plus vardenafil on-demand}

- Microbiological efficacy (pathogen eradication at the end of therapy) did not differ significantly between groups (RR 1.02, 95\% CI 0.90 to 1.16) (Analysis 21.1).

- The NIH-CPSI pain score did not differ significantly between groups when assessed at the end of therapy (SMD $0.09,95 \%$ CI -0.55 to 0.38 ) (Analysis 21.2).

- The scores of the NIH-CPSI domains focusing on voiding symptoms and on the impact of the disease on the QoL of participants differed between groups, in favor of the fixed-dose scheme (voiding score: SMD -0.64, 95\% CI -1.11 to -0.16; QoL impact score: SMD $-0.69,95 \%$ CI -1.17 to -0.21 ) (Analysis 21.2).

- Clinical efficacy, expressed as improvement of inflammatory findings (number of participants with leukocytosis in postmassage urine specimens at the end of treatment), did not differ significantly between groups (RR 0.73 , 95\% CI 0.22 to 2.35 ) (Analysis 21.3).

- Clinical efficacy, expressed as urinary peak flow rates (Qmax, $\mathrm{mL} / \mathrm{s}$ ), did not differ significantly between treatment groups (SMD 0.15, 95\% CI -0.31 to 0.62) (Analysis 21.4).

\section{Fluoroquinolone plus herbal extracts or supplements versus fluoroquinolone}

In one study, 154 participants were randomized to receive prulifloxacin (600 mg once daily for two weeks) combined with the products ProstaMEV and FlogMEV (Serenoa repens, oral, 160 mg once daily; Urtica dioica, oral, $120 \mathrm{mg}$ once daily; Curcuma longa, oral, $200 \mathrm{mg}$ once daily; quercetin, oral, $100 \mathrm{mg}$ once daily for two weeks), or prulifloxacin alone (600 mg once daily for two weeks) (Cai 2009).

- Total NIH-CPSI scores were significantly different between groups, when assessed both at the end of therapy (SMD -2.56, 95\% CI -3.04 to -2.08$)$ and after a six-month follow-up period (SMD $-3.78,95 \%$ CI -4.36 to -3.20 ) (Analysis 22.1). The comparison between groups was in favor of the combined therapy.

- IPSS scores were significantly different between groups, when assessed both at the end of therapy (SMD -2.21, 95\% CI 2.66 to -1.75$)$ and after a six-month follow-up period (SMD $2.50,95 \%$ CI -2.98 to -2.03 ) (Analysis 22.2). The comparison between groups was in favor of the combined therapy.

- The rate of adverse effects did not differ significantly between the treatment groups (RR 1.05, 95\% CI 0.11 to 9.76) (Analysis 22.3). 
ADDITIONAL SUMMARY OF FINDINGS [Explanation]

Lomefloxacin versus comparator fluoroquinolone for chronic bacterial prostatitis

Patient or population: patients with chronic bacterial prostatitis

Settings: outpatient

Intervention: lomefloxacin

Comparison: comparator fluoroquinolone ${ }^{1}$

\begin{tabular}{|c|c|c|c|c|c|c|}
\hline \multirow[t]{3}{*}{ Outcomes } & \multicolumn{2}{|c|}{ Illustrative comparative risks* $(95 \% \mathrm{Cl})$} & \multirow{3}{*}{$\begin{array}{l}\text { Relative effect } \\
(95 \% \mathrm{Cl})\end{array}$} & \multirow{3}{*}{$\begin{array}{l}\text { No. of participants } \\
\text { (studies) }\end{array}$} & \multirow{3}{*}{$\begin{array}{l}\text { Quality of the evidence } \\
\text { (GRADE) }\end{array}$} & \multirow[t]{3}{*}{ Comments } \\
\hline & Assumed risk & Corresponding risk & & & & \\
\hline & $\begin{array}{l}\text { Comparator } \\
\text { fluoroquinolone }\end{array}$ & Lomefloxacin & & & & \\
\hline $\begin{array}{l}\text { Microbiological efficacy } \\
\text { - pathogen eradication } \\
\text { at follow-up ( } 6 \text { months) } \\
\text { Follow-up: mean } 6 \\
\text { months }\end{array}$ & 804 per 1000 & $\begin{array}{l}771 \text { per } 1000 \\
\text { (643 to } 932)\end{array}$ & $\begin{array}{l}\text { RR } 0.96 \\
(0.8 \text { to } 1.16)\end{array}$ & $\begin{array}{l}116 \\
\text { (2 studies) }\end{array}$ & $\begin{array}{l}\oplus \oplus \bigcirc \bigcirc \\
\text { low }^{2,3}\end{array}$ & \\
\hline $\begin{array}{l}\text { Clinical efficacy - cure } \\
\text { or improvement at end } \\
\text { of treatment }\end{array}$ & See comment & See comment & Not estimable & $\begin{array}{l}0 \\
(0)\end{array}$ & See comment & $\begin{array}{l}\text { No study reported or pro- } \\
\text { vided useable data for this } \\
\text { outcome }\end{array}$ \\
\hline $\begin{array}{l}\text { Clinical efficacy - cure or } \\
\text { improvement at follow- } \\
\text { up ( } 6 \text { months) }\end{array}$ & See comment & See comment & Not estimable & $\begin{array}{l}0 \\
(0)\end{array}$ & See comment & $\begin{array}{l}\text { No study reported or pro- } \\
\text { vided useable data for this } \\
\text { outcome }\end{array}$ \\
\hline $\begin{array}{l}\text { Adverse effects of treat- } \\
\text { ment - any adverse ef- } \\
\text { fects }\end{array}$ & 212 per 1000 & $\begin{array}{l}135 \text { per } 1000 \\
\text { (72 to } 256)\end{array}$ & $\begin{array}{l}\text { RR } \mathbf{0 . 6 4} \\
(0.34 \text { to } 1.21)\end{array}$ & $\begin{array}{l}215 \\
\text { (2 studies) }\end{array}$ & $\begin{array}{l}\oplus \oplus \oplus \bigcirc \\
\text { moderate }{ }^{2,3}\end{array}$ & \\
\hline
\end{tabular}

*The basis for the assumed risk (e.g. the median control group risk across studies) is provided in footnotes. The corresponding risk (and its $95 \% \mathrm{Cl}$ ) is based on the assumed risk in the comparison group and the relative effect of the intervention (and its $95 \% \mathrm{Cl}$ ).

Cl: Confidence interval; No.: Number; RR: Risk ratio 
GRADE Working Group grades of evidence

High quality: Further research is very unlikely to change our confidence in the estimate of effect.

Moderate quality: Further research is likely to have an important impact on our confidence in the estimate of effect and may change the estimate.

Low quality: Further research is very likely to have an important impact on our confidence in the estimate of effect and is likely to change the estimate.

Very low quality: We are very uncertain about the estimate.

${ }^{1}$ The comparator fluoroquinolone was ofloxacin (Koff 1996) or ciprofloxacin (Naber 2002).

2 Naber 2002 - high risk of performance bias.

${ }^{3}$ Koff 1996 - high risk of selection bias and reporting bias. 
Ciprofloxacin versus comparator fluoroquinolone for chronic bacterial prostatitis

Patient or population: patients with chronic bacterial prostatitis

Settings: outpatient

Intervention: ciprofloxacin

Comparison: comparator fluoroquinolone

\begin{tabular}{|c|c|c|c|c|c|}
\hline \multirow[t]{3}{*}{ Outcomes } & \multicolumn{2}{|c|}{ Illustrative comparative risks* $(95 \% \mathrm{Cl})$} & \multirow{3}{*}{$\begin{array}{l}\text { Relative effect } \\
(95 \% \text { Cl) }\end{array}$} & \multirow{3}{*}{$\begin{array}{l}\text { No. of participants } \\
\text { (studies) }\end{array}$} & \multirow{3}{*}{$\begin{array}{l}\text { Quality of the evidence } \\
\text { (GRADE) }\end{array}$} \\
\hline & Assumed risk & Corresponding risk & & & \\
\hline & Comparator fluoroquinolone & Ciprofloxacin & & & \\
\hline $\begin{array}{l}\text { Microbiological efficacy - } \\
\text { pathogen eradication at end } \\
\text { of treatment }\end{array}$ & 806 per 1000 & $\begin{array}{l}733 \text { per } 1000 \\
\text { (564 to } 951)\end{array}$ & $\begin{array}{l}\text { RR } 0.91 \\
\text { (0.7 to 1.18) }\end{array}$ & $\begin{array}{l}851 \\
\text { (3 studies) }\end{array}$ & $\begin{array}{l}\oplus \bigcirc \bigcirc \bigcirc \\
\text { very low }\end{array}$ \\
\hline $\begin{array}{l}\text { Clinical efficacy - cure or im- } \\
\text { provement at end of treat- } \\
\text { ment }\end{array}$ & 879 per 1000 & $\begin{array}{l}791 \text { per } 1000 \\
\text { (659 to } 949)\end{array}$ & $\begin{array}{l}\text { RR } 0.9 \\
(0.75 \text { to } 1.08)\end{array}$ & $\begin{array}{l}851 \\
\text { (3 studies) }\end{array}$ & $\begin{array}{l}\oplus \bigcirc \bigcirc \bigcirc \\
\text { very low } \text { low }^{2,4,5}\end{array}$ \\
\hline $\begin{array}{l}\text { Clinical efficacy - cure or } \\
\text { improvement at follow-up ( } 6 \\
\text { months) } \\
\text { Follow-up: mean } 6 \text { months }\end{array}$ & 808 per 1000 & $\begin{array}{l}752 \text { per } 1000 \\
(582 \text { to } 970)\end{array}$ & $\begin{array}{l}\text { RR } 0.93 \\
\text { (0.72 to } 1.2)\end{array}$ & $\begin{array}{l}851 \\
\text { (3 studies) }\end{array}$ & $\begin{array}{l}\oplus \bigcirc \bigcirc \bigcirc \\
\text { very low }{ }^{2,3,4,5}\end{array}$ \\
\hline $\begin{array}{l}\text { Adverse effects of treatment } \\
\text { - any adverse effects }\end{array}$ & 212 per 1000 & $\begin{array}{l}246 \text { per } 1000 \\
\text { (202 to } 302)\end{array}$ & $\begin{array}{l}\text { RR } 1.16 \\
\text { (0.95 to } 1.42)\end{array}$ & $\begin{array}{l}967 \\
\text { (3 studies) }\end{array}$ & $\begin{array}{l}\oplus \oplus \oplus \bigcirc \\
\text { moderate }^{2,3,4}\end{array}$ \\
\hline
\end{tabular}

*The basis for the assumed risk (e.g. the median control group risk across studies) is provided in footnotes. The corresponding risk (and its $95 \% \mathrm{Cl}$ ) is based on the assumed risk in the comparison group and the relative effect of the intervention (and its $95 \% \mathrm{Cl}$ ).

Cl: Confidence interval; No.: Number; RR: Risk ratio 
GRADE Working Group grades of evidence

High quality: Further research is very unlikely to change our confidence in the estimate of effect.

Moderate quality: Further research is likely to have an important impact on our confidence in the estimate of effect and may change the estimate.

Low quality: Further research is very likely to have an important impact on our confidence in the estimate of effect and is likely to change the estimate.

Very low quality: We are very uncertain about the estimate.

${ }^{1}$ The comparator fluoroquinolone was levofloxacin (Bundrick 2003; Zhang 2012) or lomefloxacin (Naber 2002)

2 Bundrick 2003 - high risk of reporting bias.

${ }^{3}$ Naber 2002 - high risk of performance bias.

${ }^{4}$ Zhang 2012 - high risk of performance bias, reporting bias and other bias (study design).

${ }^{5}$ Zhang 2012 is the most likely source of increased heterogeneity (Analysis 6). 


\begin{tabular}{|c|c|c|c|c|c|c|}
\hline \multicolumn{7}{|c|}{ Levofloxacin versus comparator fluoroquinolone for chronic bacterial prostatitis } \\
\hline \multicolumn{7}{|c|}{$\begin{array}{l}\text { Patient or population: patients with chronic bacterial prostatitis } \\
\text { Settings: outpatient } \\
\text { Intervention: levofloxacin } \\
\text { Comparison: comparator fluoroquinolone }{ }^{1}\end{array}$} \\
\hline \multirow[t]{3}{*}{ Outcomes } & \multicolumn{2}{|c|}{ Illustrative comparative risks* $(95 \%$ Cl) } & \multirow{3}{*}{$\begin{array}{l}\text { Relative effect } \\
(95 \% \mathrm{Cl})\end{array}$} & \multirow{3}{*}{$\begin{array}{l}\text { No. of participants } \\
\text { (studies) }\end{array}$} & \multirow{3}{*}{$\begin{array}{l}\text { Quality of the evidence } \\
\text { (GRADE) }\end{array}$} & \multirow[t]{3}{*}{ Comments } \\
\hline & Assumed risk & Corresponding risk & & & & \\
\hline & $\begin{array}{l}\text { Comparator } \\
\text { fluoroquinolone }\end{array}$ & Levofloxacin & & & & \\
\hline $\begin{array}{l}\text { Microbiological efficacy } \\
\text { - pathogen eradication }\end{array}$ & 674 per 1000 & $\begin{array}{l}755 \text { per } 1000 \\
\text { (566 to } 997)\end{array}$ & $\begin{array}{l}\text { RR } 1.12 \\
\text { (0.84 to } 1.48)\end{array}$ & $\begin{array}{l}758 \\
\text { (3 studies) }\end{array}$ & $\begin{array}{l}\oplus \bigcirc \bigcirc \bigcirc \\
\text { very low }\end{array}$ & \\
\hline $\begin{array}{l}\text { Clinical efficacy - cure } \\
\text { or improvement at end } \\
\text { of treatment }\end{array}$ & See comment & See comment & Not estimable & $\begin{array}{l}0 \\
(0)\end{array}$ & See comment & $\begin{array}{l}\text { No study reported or pro- } \\
\text { vided useable data for this } \\
\text { outcome }\end{array}$ \\
\hline $\begin{array}{l}\text { Clinical efficacy - cure or } \\
\text { improvement at follow- } \\
\text { up ( } 6 \text { months) }\end{array}$ & See comment & See comment & Not estimable & $\begin{array}{l}0 \\
(0)\end{array}$ & See comment & $\begin{array}{l}\text { No study reported or pro- } \\
\text { vided useable data for this } \\
\text { outcome }\end{array}$ \\
\hline $\begin{array}{l}\text { Adverse effects of treat- } \\
\text { ment - any adverse ef- } \\
\text { fects }\end{array}$ & 258 per 1000 & $\begin{array}{l}227 \text { per } 1000 \\
\text { (186 to 278) }\end{array}$ & $\begin{array}{l}\text { RR } 0.88 \\
\text { (0.72 to } 1.08)\end{array}$ & $\begin{array}{l}874 \\
\text { (3 studies) }\end{array}$ & $\begin{array}{l}\oplus \oplus \oplus \bigcirc \\
\text { moderate }^{2,3,4}\end{array}$ & \\
\hline
\end{tabular}

*The basis for the assumed risk (e.g. the median control group risk across studies) is provided in footnotes. The corresponding risk (and its $95 \% \mathrm{Cl}$ ) is based on the assumed risk in the comparison group and the relative effect of the intervention (and its $95 \% \mathrm{Cl}$ ).

CI: Confidence interval; No.: Number; RR: Risk ratio 
GRADE Working Group grades of evidence

High quality: Further research is very unlikely to change our confidence in the estimate of effect.

Moderate quality: Further research is likely to have an important impact on our confidence in the estimate of effect and may change the estimate.

Low quality: Further research is very likely to have an important impact on our confidence in the estimate of effect and is likely to change the estimate.

Very low quality: We are very uncertain about the estimate.

${ }^{1}$ The comparator fluoroquinolone was ciprofloxacin (Bundrick 2003; Zhang 2012) or prulifloxacin (Giannarini 2007)

2 Bundrick 2003 - high risk of reporting bias.

${ }^{3}$ Giannarini 2007 - high risk of reporting bias.

${ }^{4}$ Zhang 2012 - high risk of performance bias, reporting bias and other bias (study design).

5 Zhang 2012 is the most likely source of increased heterogeneity (Analysis 7). 


\section{DISCUSSION}

\section{Summary of main results}

\section{Therapy of infection caused by traditional pathogens}

Fluoroquinolones are universally recommended as first-line agents for CBP. The results of four out of five studies directly comparing two different fluoroquinolones indicate substantial equivalence between levofloxacin and ciprofloxacin, prulifloxacin and levofloxacin, lomefloxacin and ofloxacin, and lomefloxacin and ciprofloxacin. Equivalence was shown both at the microbiological (eradication of diverse causative pathogens) and clinical levels, at the end of treatment and at follow-up (Bundrick 2003; Giannarini 2007; Koff 1996; Naber 2002). The rates of adverse effects of therapy also appeared to be equivalent in the compared treatment arms.

Pooled analysis of lomefloxacin versus comparator fluoroquinolones confirmed such equivalence (RR for microbiological efficacy at follow-up $0.96,95 \%$ CI 0.80 to 1.16 ) (Summary of findings 2).

In contrast to the Bundrick trial (Bundrick 2003), the study by Zhang and colleagues indicated increased microbiological eradication rates and increased rates of cured or improved participants in the levofloxacin arm, both at the end of treatment and at the end of a six-month follow-up period (Zhang 2012). When the Bundrick and Zhang pooled studies were analyzed by a random-effects model, the difference between levofloxacin and ciprofloxacin was not significant (microbiological efficacy: RR 1.18, 95\% CI 0.81 to 1.71 ; clinical efficacy at the end of therapy: RR $1.16,95 \% \mathrm{CI}$ 0.93 to 1.46 ) (Summary of findings for the main comparison). The discrepancy between these studies influenced the outcomes of pooled analyses 1, 6 and 7. Summary of findings tables 1, 3 and 4 present in a synthetic form the outcome of such meta-analyses (Summary of findings for the main comparison; Summary of findings 3; Summary of findings 4). The possible reasons for this discrepancy are discussed in the 'Quality of the evidence' section below.

Lomefloxacin is not inferior to co-trimoxazole at both the microbiological and clinical levels (Bustillo 1997). To be effective, the latter agent should be administered for extended periods of time (six to 12 weeks) (Smith 1979).

Beta-lactams were shown in two low powered studies to be not inferior to fluoroquinolones (ofloxacin) or tetracyclines (minocycline) at the microbiological and clinical levels (Cox 1989; Paulson 1986).

\section{Therapy of infection caused by obligate or facultative intracellular pathogens}

Macrolides were shown to be more effective than fluoroquinolones in chlamydial prostatitis. Microbiological and clinical outcomes were superior for azithromycin when compared to ciprofloxacin (Skerk 2003). The rate of adverse effects of therapy did not differ between the treatment arms.

Different macrolides, like azithromycin and clarithromycin, showed equivalent activity against chlamydial CBP (Skerk 2002). Therapy with thrice weekly doses of azithromycin ( $500 \mathrm{mg}$ once daily) may last as little as three weeks without apparent loss of microbiological or clinical efficacy compared to longer courses of treatment (Skerk 2004b). Macrolides were also equivalent to tetracyclines in both chlamydial and ureaplasmal prostatitis, both at the microbiological and clinical levels (Skerk 2004a; Skerk 2006). Fluoroquinolones (prulifloxacin) were shown to be as effective as tetracyclines (doxycycline) in chlamydial prostatitis (Cai 2010). Although prulifloxacin was more effective in attenuating clinical symptoms at the test-of-cure (TOC) visit, equivalent numbers of participants were asymptomatic at the same time point. Similarly, fluoroquinolones (ofloxacin) and tetracyclines (minocycline) show comparable microbiological and clinical efficacy and an equivalent safety profile in ureaplasmal prostatitis (Ohkawa 1993).

In summary, macrolides appear to be the most effective agents against CBP caused by intracellular pathogens.

\section{Combination therapy - all pathogens}

Combination of a fluoroquinolone with a phosphodiesterase- 5 inhibitor (levofloxacin plus vardenafil) neither improves microbiological eradication nor attenuates pain or voiding symptoms when compared to therapy with the fluoroquinolone alone. However, the impact of the disease on patients' QoL is significantly improved by the sole fluoroquinolone when compared to therapy with the fluoroquinolone plus phosphodiesterase- 5 inhibitor ondemand, though the difference was not observed when the phosphodiesterase- 5 inhibitor was administered at a fixed daily dose (10 mg once daily) (Aliaev 2008).

Combination of a fluoroquinolone (prulifloxacin) with various herbal preparations may attenuate clinical symptoms without increasing the rate of adverse effects (Cai 2009).

\section{Overall completeness and applicability of evidence}

The evidence resulting from this systematic review is applicable to patients broadly fulfilling the specific inclusion and exclusion criteria of the study.

Patients should be diagnosed and classified according to the NIH (Schaeffer 2004) or Drach's criteria (Drach 1978).

The microbiological diagnosis should be based on correctly performed standard lower urinary tract segmented tests (for example, 4-glass or 2-glass tests) for the isolation of causative pathogens from expressed prostatic secretions or post-massage urine. A diagnosis of CBP based on the sole sperm or midstream urine culture is doubtful and methodologically incorrect. 
The antimicrobial agents described in this review must be administered at the correct doses, and the therapy should be long-term, as demonstrated in all included studies. This is an essential requirement for correct and effective applicability of the evidence described in this review.

The massive worldwide onset of chemoresistance that occurred in the last two decades has likely hindered the relevance and applicability in contemporary practice of evidence derived from studies focusing on drugs like co-trimoxazole or extended-spectrum betalactamase (ESBL) targeted beta-lactam antibiotics. This should be taken into account in clinical decision-making and therapy design processes.

\section{Quality of the evidence}

The overall quality of the evidence described in this review is affected by the methodological limitations of the included studies. In particular, the more recent and better-designed trials on novel fluoroquinolones (levofloxacin, lomefloxacin, prulifloxacin) were de facto characterized by equivalency or non-inferiority designs. It is well-known that non-inferiority studies have a number of inherent weaknesses compared to superiority studies (Njue 2011). Seven out of 18 studies described antimicrobial treatment against CBP caused by a single pathogen: five studies were focusing on chlamydial infections (Cai 2010; Skerk 2002; Skerk 2003; Skerk 2004a; Skerk 2004b), and two studies included only participants with CBP caused by Ureaplasma urealyticum (Ohkawa 1993; Skerk 2006). The remaining 11 studies included participants with infection caused by any pathogen (Gram-positive or Gram-negative). Pooled pathogens may represent a limitation and a confounding factor for the resulting evidence since certain antimicrobials are more active against a particular family or group of pathogens (for example, first-generation fluoroquinolones are less active against Gram-positive bacteria than fourth-generation agents).

Three out of 18 included studies were double-blinded (Bundrick 2003; Giannarini 2007; Smith 1979), and one was single-blinded (Paulson 1986). Four studies assessed clinical symptoms using an internationally validated scoring system (NIH-CPSI) (Aliaev 2008; Cai 2009; Cai 2010; Giannarini 2007). The remaining studies adopted non-validated qualitative evaluation systems (for example, 'cure' versus 'failure'). Only two studies reported in detail the randomization procedure or the system adopted for allocation concealment (Bundrick 2003; Giannarini 2007).

A clinical outcome was absent in two studies (Koff 1996; Smith 1979), and adverse effects of treatment were not reported in three studies (Aliaev 2008; Ohkawa 1993; Paulson 1986). Eradication data at the TOC visit (end of therapy) were not disclosed in one study (Koff 1996).

In general, most of the included studies were characterized by a very low sample size.

Meta-analysis was performed to compare levofloxacin versus ciprofloxacin (two studies: Analysis 1.1; Summary of findings for the main comparison), lomefloxacin versus a comparator fluoroquinolone (Analysis 5.1; Summary of findings 2), ciprofloxacin versus a comparator fluoroquinolone (Analysis 6.1; Summary of findings 3), and levofloxacin versus a comparator fluoroquinolone (Analysis 7.1; Summary of findings 4). Three out of four pooled analyses (Analysis 1.1; Analysis 6.1; Analysis 7.1) showed very high heterogeneity of microbiological outcomes $\left(\mathrm{I}^{2}=94,91\right.$ and 89, respectively). The Zhang 2012 study was identified as the likely source of heterogeneity. This trial included a fraction of participants with CBP caused by ciprofloxacin-resistant pathogens (about $40 \%$ of the isolated pathogens). In the same patient population, $21 \%$ of isolates were resistant to levofloxacin. Thus, each group randomized to ciprofloxacin or levofloxacin contained unbalanced fractions of ciprofloxacin or levofloxacin resistant cases, and the lower eradication rate achieved by ciprofloxacin in this study is the probable source of substantial heterogeneity in the meta-analysis. When the Zhang study was excluded from metaanalysis of microbiological efficacy, heterogeneity became zero in pooled analyses 6.2.2 and 7.2.2. In addition, microbiological efficacy lost significance in pooled analyses 1, 6 and 7 when the original fixed-effect model was changed to a random-effects model (Analysis 1.2; Analysis 6.2; Analysis 7.2).

\section{Agreements and disagreements with other studies or reviews}

A single systematic review focusing on both chronic bacterial and abacterial prostatitis was retrieved from the PubMed database ( Erickson 2008). This systematic review included both randomized and observational trials and did not contain a meta-analysis. The primary outcomes of this review were symptom improvement, urodynamics, QoL, rates of bacteriological cure and adverse effects of treatment. The quality of the evidence was rated according to the GRADE criteria (Guyatt 2008). EMBASE, CENTRAL and PubMed international databases were searched.

The Bundrick 2003, Giannarini 2007 and Naber 2002 comparisons between different fluoroquinolones were analyzed. The conclusions drawn in the Erickson paper and in the present review are similar: lomefloxacin or levofloxacin are as effective as ciprofloxacin at increasing bacteriological cure rates, and prulifloxacin and levofloxacin are equally effective at increasing microbiological eradication rates in men with chronic bacterial prostatitis (Erickson 2008).

The Erickson review included a randomized study by $\mathrm{Hu}$ and coworkers focusing on intraprostatic administration of aminoglycosides (Hu 2002). We excluded the study from the present review because the description of the microbiological diagnostic methods was considered insufficient.

The present review differed from Erickson 2008 concerning the evaluation of the quality of evidence according to the GRADE system. In general, the quality rating given to the included studies is lower in the present systematic review. We attribute this differ- 
ential evaluation to the downgrading effect of selection, performance, detection, attrition and reporting biases, assessed with the Cochrane Collaboration risk of bias tool.

Beta-lactams were shown in two studies to be not inferior to fluoroquinolones (ofloxacin) or tetracyclines (minocycline) at the microbiological and clinical levels (Cox 1989; Paulson 1986). This evidence appears to be in contrast with more recent findings demonstrating very limited distribution, and hence low activity, of beta-lactam antibiotics into the prostatic tissue (Charalabopoulos 2003).

\section{A U THORS' CONCLUSIONS}

\section{Implications for practice}

The following implications for practice in the treatment of patients with chronic bacterial prostatitis (CBP) have been identified:

1. Patients with CBP are discriminated according to their etiologic cause into infections caused by traditional pathogens and infections caused by intracellular pathogens.

2. In patients with CBP caused by traditional pathogens, the majority of studies were performed with oral fluoroquinolones at treatment durations of three, four and six weeks. There are no significant differences in microbiological and clinical efficacy, and in adverse effect rates, between the oral fluoroquinolones ciprofloxacin, levofloxacin, lomefloxacin, ofloxacin and prulifloxacin.

3. No conclusion can be drawn regarding the optimal treatment duration of fluoroquinolones in the treatment of CBP caused by traditional pathogens.

4. Alternative antimicrobial agents tested for treatment of CBP caused by traditional pathogens are co-trimoxazole, beta-lactams and tetracyclines, tested for four and six weeks duration. The studies were underpowered, therefore no conclusive evidence can be drawn regarding the role of non-fluoroquinolone antibiotics in the treatment of CBP caused by traditional pathogens.

5. In patients with CBP caused by intracellular pathogens, macrolides had higher microbiological and clinical cure rates compared to fluoroquinolones at treatment durations of three weeks. There are no significant differences regarding adverse effects. There are no significant differences in microbiological and clinical efficacy and adverse effects between oral azithromycin and clarithromycin in chlamydial prostatitis.

6. There are also no significant differences in microbiological and clinical efficacy and adverse effect rates between macrolides and tetracyclines (viz., azithromycin versus doxycycline) in patients with CBP caused by facultative or obligate intracellular pathogens.

7. There is inconclusive randomized controlled evidence regarding the role of combination treatments of CBP with antimicrobial and non-antimicrobial substances, such as phosphodiesterase-5 inhibitors or herbal preparations.

\section{Implications for research}

Further RCTs are required to determine the microbiological and clinical efficacy in the treatment of:

- CBP caused by traditional pathogens with nonfluoroquinolone antimicrobial agents;

- CBP caused by fluoroquinolone-resistant pathogens with non-fluoroquinolone antimicrobial agents in the light of the increasing fluoroquinolone resistance reported in CBP isolates; and

- CBP caused by traditional as well as intracellular pathogens with antimicrobial and non-antimicrobial substances as combination treatments.

\section{ACKNOW LEDGEMENTS}

We acknowledge Dr Letizia Pelucchi, chief librarian of the Library for Medicine and Sciences of the University of Insubria, Varese, Italy, for assistance in designing the search strategies for randomized trials for inclusion in this review.

We acknowledge the Prostatitis Foundation (USA) for critical appraisal of the present review. 


\section{R E F E R E N C E S}

\section{References to studies included in this review}

Aliaev 2008 \{published data only\}

Aliaev LuG, Vinarov AZ, Akhvlediani ND. Wardenafil in combined treatment of patients with chronic bacterial prostatitis. Urologiia (Moscow, Russia: 1999) 2008;6:52-5. [PUBMED: 19256057]

Bundrick 2003 \{published and unpublished data\} Bundrick W, Heron SP, Ray P, Schiff WM, Tennenberg AM, Wiesinger BA, et al. Levofloxacin versus ciprofloxacin in the treatment of chronic bacterial prostatitis: a randomized double-blind multicenter study. Urology 2003;62(3): 537-41. [PUBMED: 12946763]

Bustillo 1997 \{published data only\} Hernandez Bustillo M, Calderon F, Marina JM, Barreda R. [Lomefloxacino s. trimetoprim/sulfametoxazol en el tratamiento de la prostatitis bacteriana cronica]. Boletín del Colegio Mexicano de Urología 1997;14:94-7.

Cai 2009 \{published data only\} Cai T, Mazzoli S, Bechi A, Addonisio P, Mondaini N, Pagliai $\mathrm{RC}$, et al. Serenoa repens associated with Urtica dioica (ProstaMEV) and curcumin and quercitin (FlogMEV) extracts are able to improve the efficacy of prulifloxacin in bacterial prostatitis patients: results from a prospective randomised study. International Journal of Antimicrobial Agents 2009;33(6):549-53. [PUBMED: 19181486]

Cai 2010 \{published data only\}

Cai T, Mazzoli S, Addonisio P, Boddi V, Geppetti P, Bartoletti R. Clinical and microbiological efficacy of prulifloxacin for the treatment of chronic bacterial prostatitis due to Chlamydia trachomatis infection: results from a prospective, randomized and open-label study. Methods and Findings in Experimental and Clinical Pharmacology 2010; 32(1):39-45. [PUBMED: 20383345]

Cox 1989 \{published data only\}

Cox CE. Ofloxacin in the management of complicated urinary tract infections, including prostatitis. The American Journal of Medicine 1989;87(6C):61S-8S. [PUBMED: 2690622]

Giannarini 2007 \{published data only\} Giannarini G, Mogorovich A, Valent F, Morelli G, De Maria M, Manassero F, et al. Prulifloxacin versus levofloxacin in the treatment of chronic bacterial prostatitis: a prospective, randomized, double-blind trial. Journal of Chemotherapy 2007;19(3):304-8. [PUBMED: 17594926]

Koff 1996 \{published data only\}

* Koff W. Clinical trial comparing lomefloxacin and ofloxacin in the treatment of chronic bacterial prostatitis [Estudo comparativo entre lomefloxacina e ofloxacina no tratamento da prostatite bacteriana cronica]. Revista Brasileira de Medicina 1996;53(1/2):88-91.

Naber 2002 \{published data only\}

Naber KG. Lomefloxacin versus ciprofloxacin in the treatment of chronic bacterial prostatitis. International
Journal of Antimicrobial Agents 2002;20(1):18-27.

[PUBMED: 12127707]

Ohkawa 1993 \{published data only\}

Ohkawa M, Yamaguchi K, Tokunaga S, Nakashima T,

Shoda R. Antimicrobial treatment for chronic prostatitis as a means of defining the role of Ureaplasma urealyticum. Urologia Internationalis 1993;51(3):129-32. [PUBMED: 8249222]

Paulson 1986 \{published data only\} Paulson DF, Zinner NR, Resnick MI, Childs SJ, Love T, Madsen PO. Treatment of bacterial prostatitis. Comparison of cephalexin and minocycline. Urology 1986;27(4): 379-87. [PUBMED: 3515737]

\section{Skerk 2002 \{published data only\}}

Skerk V, Schonwald S, Krhen I, Markovinovic L, Barsic B, Marekovic I, et al. Comparative analysis of azithromycin and clarithromycin efficacy and tolerability in the treatment of chronic prostatitis caused by Chlamydia trachomatis. Journal of Chemotherapy 2002;14(4):384-9. [PUBMED: 12420857]

Skerk 2003 \{published data only\} Skerk V, Schonwald S, Krhen I, Banaszak A, Begovac J, Strugar J, et al. Comparative analysis of azithromycin and ciprofloxacin in the treatment of chronic prostatitis caused by Chlamydia trachomatis. International Journal of Antimicrobial Agents 2003;21(5):457-62. [PUBMED: 12727080]

Skerk 2004a \{published data only\}

Skerk V, Krhen I, Lisic M, Begovac J, Roglic S, Skerk V, et al. Comparative randomized pilot study of azithromycin and doxycycline efficacy in the treatment of prostate infection caused by Chlamydia trachomatis. International Journal of Antimicrobial Agents 2004;24(2):188-91. [PUBMED: 15288321]

\section{Skerk 2004b \{published data only\}}

Skerk V, Krhen I, Lisic M, Begovac J, Cajic V, Zekan S, et al. Azithromycin: 4.5- or 6.0-gram dose in the treatment of patients with chronic prostatitis caused by Chlamydia trachomatis--a randomized study. Journal of Chemotherapy 2004; Vol. 16, issue 4:408-10. [PUBMED: 15332719]

\section{Skerk 2006 \{published data only\}}

Skerk V, Marekovic I, Markovinovic L, Begovac J, Skerk V, Barsic N, et al. Comparative randomized pilot study of azithromycin and doxycycline efficacy and tolerability in the treatment of prostate infection caused by Ureaplasma urealyticum. Chemotherapy 2006;52(1):9-11. [PUBMED: 16340190]

Smith 1979 \{published data only\}

Smith JW, Jones SR, Reed WP, Tice AD, Deupree RH, Kaijser B. Recurrent urinary tract infections in men. Characteristics and response to therapy. Annals of Internal Medicine 1979;91(4):544-8. [PUBMED: 384858] 
Zhang 2012 \{published data only\}

Zhang ZC, Jin FS, Liu DM, Shen ZJ, Sun YH, Guo YL. Safety and efficacy of levofloxacin versus ciprofloxacin for the treatment of chronic bacterial prostatitis in Chinese patients. Asian Journal of Andrology 2012;14(6):870-4.

\section{References to studies excluded from this review}

Ateya 2006 \{published data only\}

Ateya A, Fayez A, Hani R, Zohdy W, Gabbar MA, Shamloul R. Evaluation of prostatic massage in treatment of chronic prostatitis. Urology 2006;67(4):674-8. [PUBMED: 16566972]

Baert 1983 \{published data only\}

Baert L, Mattelaer J, de Nollin P. Treatment of chronic bacterial prostatitis by local injection of antibiotics into prostate. Urology 1983;21(4):370-5. [PUBMED: 6836824]

Barbalias 1998 \{published data only\} Barbalias GA, Nikiforidis G, Liatsikos EN. Alpha-blockers for the treatment of chronic prostatitis in combination with antibiotics. The Journal of Urology 1998;159(3):883-7. [PUBMED: 9474175]

\section{Brannan 1975 \{published data only\}}

Brannan W. Treatment of chronic prostatitis. Comparison of minocycline and doxycycline. Urology 1975;5(5): 626-31. [PUBMED: 1093309]

Cai 2011 \{published data only\}

Cai T, Wagenlehner FM, Mazzoli S, Meacci F, Mondaini N, Nesi G, et al. Semen quality in patients with Chlamydia trachomatis genital infection treated concurrently with prulifloxacin and a phytotherapeutic agent. Journal of Andrology 2011;33(4):615-23. [PUBMED: 21979301]

Childs 1983 \{published data only\}

Childs SJ, Wells WG, Chubb JM. Ceftazidime, an open randomized comparison of 3 dosages for genitourinary infections. The Journal of Urology 1983;130(3):495-7. [PUBMED: 6350616]

\section{Colleen 1975 \{published data only\}}

Colleen S, Mardh PA. Effect of metacycline treatment on non-acute prostatitis. Scandinavian Journal of Urology and Nephrology 1975;9(3):198-204. [PUBMED: 813297]

\section{Cox 1991 \{published data only\}}

Cox CE, Childs SJ. Treatment of chronic bacterial prostatitis with temafloxacin. The American Journal of Medicine 1991; 91(6A):134S-9S. [PUBMED: 1662884]

Deng 2004 \{published data only\} Deng C, Zheng B, She S. [Clinical study of zinc for the treatment of chronic bacterial prostatitis]. Zhonghua Nan Ke Xue = National Journal of Andrology 2004;10(5):368-70. [PUBMED: 15190832]

Gleckman 1979 \{published data only\}

Gleckman R, Crowley M, Natsios GA. Therapy of recurrent invasive urinary-tract infections of men. The New England Journal of Medicine 1979;301(16):878-80. [PUBMED: 384251]
Hu 2002 \{published data only\}

$\mathrm{Hu}$ WL, Zhong SZ, He HX. Treatment of chronic bacterial prostatitis with amikacin through anal submucosal injection. Asian Journal of Andrology 2002;4(3):163-7. [PUBMED: 12364969]

Kim 2006 \{published data only\}

Kim YJ, Ryu JK, LEE HJ, Choi WS, Suh JK. Comparison of the efficacy of transperineal intraprostatic injection and oral administration of fluoroquinolone in men with chronic bacterial prostatitis-seminal vesiculitis. Korean Journal of Urology 2006;47:1185-90.

Kozdoba 2007 \{published data only\}

Kozdoba AS, Popov SV, Ivanchenko LP. [Complex therapy of chronic bacterial prostatitis using matrix-urologist laser therapy]. Urologiia (Moscow, Russia: 1999) 2007;5:51, 535. [PUBMED: 18257156]

\section{Kunishima 2008 \{published data only\}}

Kunishima Y, Takeyama K, Takahashi S, Matsukawa M, Koroku M, Tanda $\mathrm{H}$, et al. Gatifloxacin treatment for chronic prostatitis: a prospective multicenter clinical trial. Journal of Infection and Chemotherapy 2008;14(2):137-40. [PUBMED: 18622677]

Lee 2006 \{published data only\}

Lee SD, Lee SJ, Hwang TK, Yoon DK, Lee KS, Sung LH, et al. Efficacy and safety of gatifloxacin for urinary tract infection in nonspecialized Korean urologic practice. International Journal of Antimicrobial Agents 2006;28 Suppl 1:S108-12. [PUBMED: 16844352]

Liao 2004 \{published data only\}

Liao D, Chen Z, Deng Z, Wang D. Xinxibao for the treatment of chronic bacterial prostatitis. Zhonghua Nan Ke Xue $=$ National Journal of Andrology 2004;10(9):676-7. [PUBMED: 15497709]

Martino 1993 \{published data only\}

Martino P, Ricapito V, Sblendorio D, Disabato G, Battaglia $\mathrm{M}$, Carrieri G, et al. Transrectal echography in the evaluation of the effects of endocavitary laser therapy in patients with bacterial prostatitis [L'ecografia transrettale nella valutazione degli effetti indotti dalla laser terapia endocavitaria in pazienti portatori di prostatite batterica]. Archivio Italiano di Urologia, Andrologia 1993;65(4):391-6. [PUBMED: 8353547]

Nickel 2008a \{published data only\}

Nickel JC, Xiang J. Clinical significance of nontraditional bacterial uropathogens in the management of chronic prostatitis. The Journal of Urology 2008;179(4):1391-5. [PUBMED: 18289570]

Paglia 2010 \{published data only\} Paglia M, Peterson J, Fisher AC, Qin Z, Nicholson SC, Kahn JB. Safety and efficacy of levofloxacin $750 \mathrm{mg}$ for 2 weeks or 3 weeks compared with levofloxacin $500 \mathrm{mg}$ for 4 weeks in treating chronic bacterial prostatitis. Current Medical Research and Opinion 2010;26(6):1433-41. [PUBMED: 20394471] 
Panagopoulos 2009 \{published data only\}

Panagopoulos P, Antoniadou A, Kanellakopoulou

K, Tsiodras S, Katsarolis I, Papadopoulos A, et al.

Fluoroquinolone treatment of chronic bacterial prostatitis:

a prospective cohort study. Journal of Chemotherapy 2009;

21(3):317-21. [PUBMED: 19567353]

Sabbaj 1986 \{published data only\}

Sabbaj J, Hoagland VL, Cook T. Norfloxacin versus cotrimoxazole in the treatment of recurring urinary tract infections in men. Scandinavian Journal of Infectious Diseases. Supplementum 1986;48:48-53. [PUBMED: 3490684]

Schaeffer 2005 \{published data only\}

Schaeffer AJ, Wu SC, Tennenberg AM, Kahn JB. Treatment of chronic bacterial prostatitis with levofloxacin and ciprofloxacin lowers serum prostate specific antigen. The Journal of Urology 2005;174(1):161-4. [PUBMED: 15947609]

\section{Shafik 1992 \{published data only\}}

Shafik A. Perineal versus anal submucosal injection for drug administration in treatment of chronic prostatitis. Urology 1992; Vol. 39, issue 3:297. [PUBMED: 1546432 ]

Shen 2004 \{published data only\}

Shen B, Jin X, Cai S, Chen J, Chen G, Zhao W, et al. Effect and mechanism of alpha1-adrenoceptor blocker combined with antibiotics for chronic prostatitis. Zhonghua Nan Ke Xue $=$ National Journal of Andrology 2004;10(7):518-20. [PUBMED: 15354524]

Smelov 2004 \{published data only\}

Smelov V, Gorelov A, Smelova N, Krylova T. Single-drug or combined antibacterial therapy in the treatment of patients with chronic prostatitis and Chlamydia trachomatis? International Journal of Antimicrobial Agents 2004;23 Suppl 1:S83-7. [PUBMED: 15037333]

Trapeznikova 2007 \{published data only\}

Trapeznikova MF, Morozov AP, Dutov VV, Urenkov SB, Pozdniakov KV, Bychkova NV. An open randomized comparative trial of efficacy and safety of selective alphaadrenoblocker setegis (terazosin) in therapy of patients with chronic bacterial prostatitis. Urologiia (Moscow, Russia: 1999) 2007;2:33-7. [PUBMED: 17578197]

Vicari 2000 \{published data only\}

Vicari E. Effectiveness and limits of antimicrobial treatment on seminal leukocyte concentration and related reactive oxygen species production in patients with male accessory gland infection. Human Reproduction 2000;15(12): 2536-44. [PUBMED: 11098023]

Vickovic 2010 \{published data only\}

Vickovic N, Skerk V, Granic J, Vargovic M, Pasini M, Turcic P, et al. Metronidazole 1.5 gram dose for 7 or 14 days in the treatment of patients with chronic prostatitis caused by Trichomonas vaginalis: A randomized study. Journal of Chemotherapy 2010; Vol. 22, issue 5:364-5. [PUBMED: 21123162]
Wedren 1989 \{published data only\}

Wedren H. On chronic prostatitis with special studies of Staphylococcus epidermidis. Scandinavian Journal of Urology and Nephrology. Supplementum 1989;123:1-36. [PUBMED: 2483757]

Xu 2010 \{published data only\}

Xu JC, Lu QM, Fu LJ, Chen YP. Qianlie Jiedu capsule combined with rufloxacin for chronic prostatitis: a randomized double-blind controlled clinical trial. Zhonghua Nan Ke Xue = National Journal of Andrology 2010;16(2): 183-6. [PUBMED: 20369705]

Yavaçaoğ lu 1998 \{published data only\}

Yavaçaoğ lu ĩ , Çamlı kı yı H, Oktay B, s imek Ü, Özyurt M. Percutaneous suprapubic transvesical route: a new and comfortable method of intraprostatic injection. Urologia Internationalis 1998;60(4):229-34. [PUBMED: 9701736]

Zhang 2004 \{published data only\}

Zhang W, Liu Z, Dong H, Sun C. Related pathogen examinations and therapeutic choices for chronic prostatitis following sexually transmitted diseases. Zhonghua $\mathrm{Nan} \mathrm{Ke}$ Xue = National Journal of Andrology 2004;10(4):275-7, 281. [PUBMED: 15148924]

\section{References to studies awaiting assessment}

\section{Drasa 2009 \{published data only\}}

Drasa K, Tartari F. Cefuroxime axetil vs. Ceftriaxone and both combination in treatment of chronic bacterial prostatitis: a prospective, randomized, double-blind trial. European Urology Supplements 2009;8(4):260.

\section{Additional references}

\section{Aagaard 1991}

Aagaard J, Gasser T, Rhodes P, Madsen PO. MICs of ciprofloxacin and trimethoprim for Escherichia coli: influence of $\mathrm{pH}$, inoculum size and various body fluids. Infection 1991;19 Suppl 3:S167-9. [PUBMED: 2055655]

\section{Bartoletti 2007}

Bartoletti R, Cai T, Mondaini N, Dinelli N, Pinzi N, Pavone $\mathrm{C}$, et al. Prevalence, incidence estimation, risk factors and characterization of chronic prostatitis/chronic pelvic pain syndrome in urological hospital outpatients in Italy: results of a multicenter case-control observational study. The Journal of Urology 2007;178(6):2411-5. [PUBMED: 17937946]

\section{Berges 2011}

Berges R, Oelke M. Age-stratified normal values for prostate volume, PSA, maximum urinary flow rate, IPSS, and other LUTS/BPH indicators in the German male communitydwelling population aged 50 years or older. World Journal of Urology 2011;29(2):171-8. [PUBMED: 21221974]

Charalabopoulos 2003 Charalabopoulos K, Karachalios G, Baltogiannis D, Charalabopoulos A, Giannakopoulos X, Sofikitis N. Penetration of antimicrobial agents into the prostate. Chemotherapy 2003;49(6):269-79. [PUBMED: 14671426] 


\section{Clemens 2005}

Clemens JQ, Meenan RT, O'Keeffe Rosetti MC, Gao SY, Calhoun EA. Incidence and clinical characteristics of National Institutes of Health type III prostatitis in the community. The Journal of Urology 2005;174(6):2319-22. [PUBMED: 16280832]

\section{Clemens 2009}

Clemens JQ, Markossian T, Calhoun EA. Comparison of economic impact of chronic prostatitis/chronic pelvic pain syndrome and interstitial cystitis/painful bladder syndrome. Urology 2009;73(4):743-6. [PUBMED: 19193408]

\section{Cohen 2012}

Cohen JM, Fagin AP, Hariton E, Niska JR, Pierce MW, Kuriyama A, et al. Therapeutic intervention for chronic prostatitis/chronic pelvic pain syndrome (CP/CPPS): a systematic review and meta-analysis. PLoS One 2012;7(8): e41941. [PUBMED: 22870266]

\section{Collins 1998}

Collins MM, Stafford RS, O'Leary MP, Barry MJ. How common is prostatitis? A national survey of physician visits. The Journal of Urology 1998;159(4):1224-8. [PUBMED: 9507840]

\section{Dalhoff 2005}

Dalhoff A, Schubert S, Ullmann U. Effect of $\mathrm{pH}$ on the in vitro activity of and propensity for emergence of resistance to fluoroquinolones, macrolides, and a ketolide. Infection 2005;33 Suppl 2:36-43. [PUBMED: 16518710]

\section{Daniels 2007}

Daniels NA, Link CL, Barry MJ, McKinlay JB. Association between past urinary tract infections and current symptoms suggestive of chronic prostatitis/chronic pelvic pain syndrome. Journal of the National Medical Association 2007; 99(5):509-16. [PUBMED: 17534008]

\section{Drach 1978}

Drach GW, Fair WR, Meares EM, Stamey TA. Classification of benign diseases associated with prostatic pain: prostatitis or prostatodynia?. The Journal of Urology 1978; Vol. 120, issue 2:266. [PUBMED: 671653]

Ejike 2008

Ejike CE, Ezeanyika LU. Prevalence of chronic prostatitis symptoms in a randomly surveyed adult population of urban-community-dwelling Nigerian males. International Journal of Urology 2008;15(4):340-3. [PUBMED: 18380824]

\section{Erickson 2008}

Erickson BA, Schaeffer AJ, Van Le B. Chronic prostatitis. Clinical Evidence 2008;5:1802. [PUBMED: 19450305]

\section{Ferris 2010}

Ferris JA, Pitts MK, Richters J, Simpson JM, Shelley JM, Smith AM. National prevalence of urogenital pain and prostatitis-like symptoms in Australian men using the National Institutes of Health Chronic Prostatitis Symptoms Index. BJU International 2010;105(3):373-9. [PUBMED: 19549116]

\section{Foulds 1991}

Foulds G, Madsen P, Cox C, Shepard R, Johnson R. Concentration of azithromycin in human prostatic tissue. European Journal of Clinical Microbiology \& Infectious Diseases 1991;10(10):868-71. [PUBMED: 1722460]

\section{Gesu 1987}

Gesu GP, Eftimiadi C, Debbia E, Schito GC. Effects of changes in $\mathrm{pH}$, medium and inoculum size on the in vitro activity of different quinolone and fluoroquinolone antibiotics against urinary pathogens. Drugs Under Experimental and Clinical Research 1987;13(2):79-84. [PUBMED: 3556122]

\section{Guyatt 2008}

Guyatt GH, Oxman AD, Kunz R, Vist GE, Falck-Ytter Y, Schunemann HJ. What is "quality of evidence" and why is it important to clinicians?. BMJ 2008;336(7651):995-8. [PUBMED: 18456631]

\section{Higgins 2009}

Higgins JPT, Green S (editors). Cochrane Handbook for Systematic Reviews of Interventions Version 5.0.2 [updated September 2009]. The Cochrane Collaboration, 2009. Available from www.cochrane-handbook.org (accessed 8 February 2011).

\section{Higgins 2011}

Higgins JPT, Green S (editors). Cochrane Handbook for Systematic Reviews of Interventions Version 5.1.0 [updated March 2011]. The Cochrane Collaboration, 2011. Available from www.cochrane-handbook.org.

\section{Kamberi 1999}

Kamberi M, Tsutsumi K, Kotegawa T, Kawano K, Nakamura K, Niki Y, et al. Influences of urinary $\mathrm{pH}$ on ciprofloxacin pharmacokinetics in humans and antimicrobial activity in vitro versus those of sparfloxacin. Antimicrobial Agents and Chemotherapy 1999;43(3):525-9. [PUBMED: 10049262]

\section{Krieger 1999}

Krieger JN, Nyberg L Jr, Nickel JC. NIH consensus definition and classification of prostatitis. JAMA 1999; Vol. 282, issue 3:236-7. [PUBMED: 10422990]

\section{Krieger 2008}

Krieger JN, Lee SW, Jeon J, Cheah PY, Liong ML, Riley DE. Epidemiology of prostatitis. International Journal of Antimicrobial Agents 2008;31 Suppl 1:S85-90. [PUBMED: 18164907]

\section{Liang 2009}

Liang CZ, Li HJ, Wang ZP, Xing JP, Hu WL, Zhang TF, et al. The prevalence of prostatitis-like symptoms in China. The Journal of Urology 2009;182(2):558-63. [PUBMED: 19524948]

\section{Lipsky 2010}

Lipsky BA, Byren I, Hoey CT. Treatment of bacterial prostatitis. Clinical Infectious Diseases 2010;50(12): 1641-52. [PUBMED: 20459324]

\section{McNaughton-Collins 2007}

McNaughton-Collins M, Joyce GF, Wise M, Pontari MA. Prostatitis. In: Litwin MS, Saigal CS editor(s). Urologic 
Diseases in America. US Department of Health and Human Services, Public Health Service, National Institutes of Health, National Institute of Diabetes and Digestive and Kidney Diseases. NIH Publication No. 07-5512. Washington, DC: US Government Printing Office, 2007:11-39.

\section{Meares 1975}

Meares EM Jr. Long-term therapy of chronic bacterial prostatitis with trimethoprim-sulfamethoxazole. Canadian Medical Association Journal 1975;112(13 Spec No):22-5. [PUBMED: 236820]

\section{Mehik 2000}

Mehik A, Hellstrom P, Lukkarinen O, Sarpola A, Jarvelin M. Epidemiology of prostatitis in Finnish men: a populationbased cross-sectional study. BJU International 2000;86(4): 443-8. [PUBMED: 10971269]

\section{Mehik 2001}

Mehik A, Hellstrom P, Sarpola A, Lukkarinen O, Jarvelin MR. Fears, sexual disturbances and personality features in men with prostatitis: a population-based cross-sectional study in Finland. BJU International 2001;88(1):35-8. [PUBMED: 11446842]

\section{Naber 2003}

Naber KG, Sorgel F. Antibiotic therapy - rationale and evidence for optimal drug concentrations in prostatic and seminal fluid and in prostatic tissue. Andrologia 2003;35 (5):331-5. [PUBMED: 14535866]

\section{Naber 2008}

Naber KG. Management of bacterial prostatitis: what's new? . BJU International 2008;101 Suppl 3:7-10. [PUBMED: 18307679]

\section{Nickel 2001}

Nickel JC, Downey J, Hunter D, Clark J. Prevalence of prostatitis-like symptoms in a population based study using the National Institutes of Health chronic prostatitis symptom index. The Journal of Urology 2001;165(3): 842-5. [PUBMED: 11176483]

\section{Nickel 2006}

Nickel JC, Shoskes D, Wang Y, Alexander RB, Fowler JE Jr, Zeitlin $S$, et al. How does the pre-massage and post-massage 2-glass test compare to the Meares-Stamey 4-glass test in men with chronic prostatitis/chronic pelvic pain syndrome? . The Journal of Urology 2006;176(1):119-24. [PUBMED: 16753385]

Nickel 2008b

Nickel JC, Patel M, Cameron M. Chronic prostatitis/ chronic pelvic pain syndrome: finding a way forward in the United Kingdom: report from the first United Kingdom symposium on chronic prostatitis, January 30, 2008, London, United Kingdom. Reviews in Urology 2008;10(2): 160-3. [PUBMED: 18660861]

\section{Nickel 2010}

Nickel JC, Shoskes DA. Phenotypic approach to the management of the chronic prostatitis/chronic pelvic pain syndrome. BJU International 2010;106(9):1252-63. [PUBMED: 20946349]

\section{Njue 2011}

Njue C. Statistical considerations for confirmatory clinical trials for similar biotherapeutic products. Biologicals 2011; 39(5):266-9. [PUBMED: 21807534]

\section{Perletti 2009}

Perletti G, Wagenlehner FM, Naber KG, Magri V. Enhanced distribution of fourth-generation fluoroquinolones in prostatic tissue. International Journal of Antimicrobial Agents 2009;33(3):206-10. [PUBMED: 19091519]

\section{Pontari 2007}

Pontari MA, Joyce GF, Wise M, McNaughton-Collins M. Prostatitis. The Journal of Urology 2007;177(6):2050-7. [PUBMED: 17509285]

\section{RevMan 5.1}

The Nordic Cochrane Centre, The Cochrane Collaboration. Review Manager (RevMan). 5.1. Copenhagen: The Nordic Cochrane Centre, The Cochrane Collaboration, 2011.

\section{Rizzo 2003}

Rizzo M, Marchetti F, Travaglini F, Trinchieri A, Nickel JC. Prevalence, diagnosis and treatment of prostatitis in Italy: a prospective urology outpatient practice study. $B J U$ International 2003;92(9):955-9. [PUBMED: 14632854]

\section{Schaeffer 2004}

Schaeffer AJ. NIDDK-sponsored chronic prostatitis collaborative research network (CPCRN) 5-year data and treatment guidelines for bacterial prostatitis. International Journal of Antimicrobial Agents 2004;24 Suppl 1:S49-52. [PUBMED: 15364307]

\section{Shoskes 2001}

Shoskes DA. Use of antibiotics in chronic prostatitis syndromes. The Canadian Journal of Urology 2001;8 Suppl 1:24-8. [PUBMED: 11442994]

\section{Shoskes 2009}

Shoskes DA, Nickel JC, Rackley RR, Pontari MA. Clinical phenotyping in chronic prostatitis/chronic pelvic pain syndrome and interstitial cystitis: a management strategy for urologic chronic pelvic pain syndromes. Prostate Cancer and Prostatic Diseases 2009;12(2):177-83. [PUBMED: 18645581]

\section{Stamey 1981}

Stamey TA. Prostatitis. Journal of the Royal Society of Medicine 1981;74(1):22-40. [PUBMED: 7007638]

\section{Wagenlehner 2007}

Wagenlehner FM, Weidner W, Naber KG. Therapy for prostatitis, with emphasis on bacterial prostatitis. Expert Opinion on Pharmacotherapy 2007;8(11):1667-74. [PUBMED: 17685884]

\section{Wallner 2009}

Wallner LP, Clemens JQ, Sarma AV. Prevalence of and risk factors for prostatitis in African American men: the Flint Men's Health Study. The Prostate 2009;69(1):24-32. [PUBMED: 18802926]

* Indicates the major publication for the study 


\section{CHARACTERISTICS OF STUDIES}

\section{Characteristics of included studies [ordered by study ID]}

\section{Aliaev 2008}

\begin{tabular}{|c|c|c|}
\hline Methods & \multicolumn{2}{|c|}{ Randomized, parallel group, open-label, active drug-controlled study } \\
\hline Participants & \multicolumn{2}{|c|}{$\begin{array}{l}\text { Geographic region: Russia } \\
\text { Enrolled participants: } \mathrm{n}=103 \\
\text { Randomization: } \\
\text { GROUP } 1, \mathrm{n}=32 \\
\text { GROUP } 2, \mathrm{n}=44 \\
\text { GROUP } 3, \mathrm{n}=37 \\
\text { Age (mean, overall): } 36.2 \pm 8.4 \\
\text { Inclusion: diagnosis of CBP, and history of CBP (NIH criteria). Microbiological diag- } \\
\text { nosis: } 2 \text {-glass test } \\
\text { Exclusion: criteria not specified } \\
\text { Study discontinuations: } \mathrm{n}=0 \\
\text { Study duration: } 8 \text { weeks ( } 4 \text { weeks, treatment; } 4 \text { weeks, follow-up) }\end{array}$} \\
\hline Interventions & \multicolumn{2}{|c|}{$\begin{array}{l}\text { GROUP } 1 \\
\text { Levofloxacin, oral, } 500 \mathrm{mg} \text { once daily, for } 4 \text { weeks } \\
\text { GROUP } 2 \\
\text { Levofloxacin, oral, } 500 \mathrm{mg} \text { once daily, plus vardenafil, oral, } 10 \mathrm{mg} \text { once daily, for } 4 \text { weeks } \\
\text { GROUP } 3 \\
\text { Levofloxacin, oral, } 500 \mathrm{mg} \text { once daily, plus vardenafil, oral, } 10 \mathrm{mg} \text { on-demand, for } 4 \\
\text { weeks }\end{array}$} \\
\hline Outcomes & \multicolumn{2}{|c|}{$\begin{array}{l}\text { Microbiological eradication per patient } \\
\text { Clinical improvement (NIH-CPSI test, uroflowmetry, leukocyte counts in VB3) }\end{array}$} \\
\hline Notes & \multicolumn{2}{|c|}{$\begin{array}{l}\text { The original study article (Aliaev 2008) was not retrieved from online databases. One } \\
\text { author (NDA) was contacted and provided a full written report of the study, partly } \\
\text { translated into English (abstract, tables). This report was used for the present review }\end{array}$} \\
\hline \multicolumn{3}{|l|}{ Risk of bias } \\
\hline Bias & Authors' judgement & Support for judgement \\
\hline $\begin{array}{l}\text { Random sequence generation (selection } \\
\text { bias) }\end{array}$ & Unclear risk & $\begin{array}{l}\text { "This study was of the randomized type". } \\
\text { No additional information provided }\end{array}$ \\
\hline Allocation concealment (selection bias) & Unclear risk & $\begin{array}{l}\text { Allocation concealment procedure not de- } \\
\text { scribed in study report }\end{array}$ \\
\hline $\begin{array}{l}\text { Blinding of participants and personnel } \\
\text { (performance bias) } \\
\text { All outcomes }\end{array}$ & High risk & $\begin{array}{l}\text { The use of a PDE5 inhibitor may signifi- } \\
\text { cantly influence the outcome of symptom } \\
\text { questionnaires like NIH-CPSI. NIH-CPSI } \\
\text { includes a QoL item }\end{array}$ \\
\hline
\end{tabular}


Aliaev 2008 (Continued)

\begin{tabular}{|c|c|c|}
\hline $\begin{array}{l}\text { Blinding of outcome assessment (detection } \\
\text { bias) } \\
\text { All outcomes }\end{array}$ & High risk & See above \\
\hline $\begin{array}{l}\text { Incomplete outcome data (attrition bias) } \\
\text { All outcomes }\end{array}$ & Unclear risk & $\begin{array}{l}\text { Per protocol-like analysis does not allow to } \\
\text { evaluate number of dropouts and reason for } \\
\text { study discontinuation }\end{array}$ \\
\hline Selective reporting (reporting bias) & High risk & $\begin{array}{l}\text { Information on isolated pathogens and on } \\
\text { per pathogen eradication are missing. In- } \\
\text { formation on adverse effects of treatment } \\
\text { is missing }\end{array}$ \\
\hline Other bias & Unclear risk & $\begin{array}{l}\text { No apparent baseline imbalances. Per pro- } \\
\text { tocol-like design }\end{array}$ \\
\hline
\end{tabular}

Bundrick 2003

Methods

Randomized, parallel group, double-blind, active drug-controlled, multicenter, phase 3/ b study

Participants

Geographic region: USA

Enrolled participants: $\mathrm{n}=383$ (intent-to-treat, $\mathrm{n}=377$; per protocol, $\mathrm{n}=325$; microbiologically/clinically assessable, $\mathrm{n}=321$ )

FOR MICROBIOLOGICAL OUTCOME:

Randomization:

GROUP 1, n = 170

GROUP 2, n = 151

Study discontinuations: $\mathrm{n}=60$

GROUP 1, n = 34

GROUP 2, $\mathrm{n}=26$

FOR SAFETY OUTCOME:

Randomization:

GROUP 1, n = 199

GROUP 2, n = 184

Study discontinuations: $\mathrm{n}=6$

GROUP 1, n = 2

GROUP 2, n = 4

Age: not available

Inclusion: history of CBP, clinically and microbiologically diagnosed CBP. Microbiological diagnosis: 4-glass test

Exclusion: < 18 years old; prostate cancer; ongoing therapy with drugs affecting bladder/ prostate function; prostate biopsy; cystoscopy; current or recent treatment with antimicrobials; parenteral therapy for prostatitis; pathogen resistant to study drugs; allergy to fluoroquinolones; creatinine clearance $<50 \mathrm{ml} / \mathrm{min}$; TURP, indwelling catheters, cystostomy, nephrostomy

Study duration: 7 months (4 weeks therapy; 6 months follow-up) 
Bundrick 2003 (Continued)

\begin{tabular}{ll}
\hline Interventions & $\begin{array}{l}\text { GROUP } 1 \\
\text { Levofloxacin, oral, } 500 \mathrm{mg} \text { once daily, plus placebo, once daily, for } 28 \text { days } \\
\text { GROUP } 2 \\
\text { Ciprofloxacin, oral, } 500 \mathrm{mg} \text { twice daily, for } 28 \text { days }\end{array}$ \\
\hline Outcomes & $\begin{array}{l}\text { Microbiological eradication per patient and per pathogen } \\
\text { Clinical success (cured/improved) } \\
\text { Adverse effects of treatment }\end{array}$ \\
\hline Notes & \\
\hline
\end{tabular}

Risk of bias

\begin{tabular}{|c|c|c|}
\hline Bias & Authors' judgement & Support for judgement \\
\hline $\begin{array}{l}\text { Random sequence generation (selection } \\
\text { bias) }\end{array}$ & Low risk & $\begin{array}{l}\text { "Patients randomized by a computer-gen- } \\
\text { erated schedule". Randomization was per- } \\
\text { formed by study center }\end{array}$ \\
\hline Allocation concealment (selection bias) & Unclear risk & $\begin{array}{l}\text { "Tablets were over-encapsulated to main- } \\
\text { tain blinding". It is unclear whether medi- } \\
\text { cal personnel was informed about the con- } \\
\text { tent of the encapsulated tablets. Moreover, } \\
\text { generation of the randomization sequence } \\
\text { was performed locally and not centrally }\end{array}$ \\
\hline
\end{tabular}

Blinding of participants and personnel Low risk (performance bias)

Study was double-blind. "Tablets were All outcomes over-encapsulated to maintain blinding"

Blinding of outcome assessment (detection Unclear risk bias)

All outcomes

Incomplete outcome data (attrition bias) Low risk

All outcomes
High risk
Not specified

Both drugs are equally active, belong to the same drug family (fluoroquinolones) and are known to have similar safety profiles. Reasons for participant withdrawal are expected to be similar. ITT analysis was performed

Outcome variables 2, 3, 7, and 8 from the original protocol (2, one-month post-study microbiologic relapse by subject's infection for subjects who were cured or improved at the post-therapy visit; 3, one-month poststudy microbiologic relapse by pathogen for subjects who were cured or improved at the post-therapy visit; 7 , the transition 
Bundrick 2003 (Continued)

in scores from the prostatitis symptoms index from admission to post-therapy; 8 , onemonth post-study clinical success for subjects who were cured or improved at the post-therapy visit) are not reported in the study article

Other bias

Low risk

No apparent baseline imbalance

\section{Bustillo 1997}

\begin{tabular}{|c|c|}
\hline Methods & Randomized, parallel group, open-label, active drug-controlled study \\
\hline Participants & $\begin{array}{l}\text { Geographic region: Mexico } \\
\text { Enrolled participants: } \mathrm{n}=30 \\
\text { Randomization: } \\
\text { GROUP } 1, \mathrm{n}=15 \\
\text { GROUP 2, } \mathrm{n}=15 \\
\text { Age (mean): } \\
\text { GROUP } 1,36.9 \text { years } \\
\text { GROUP 2, } 38.4 \text { years } \\
\text { Inclusion: history and diagnosis of CBP (NIH criteria). Microbiological diagnosis: 4- } \\
\text { glass test } \\
\text { Exclusion: < } 18 \text { years old; medications affecting absorption of study drugs (anti-acid, } \\
\text { sucralfate); recent treatment with antimicrobials; hypersensitivity to fluoroquinolones } \\
\text { or co-trimoxazole; terminal disease, cystostomy or urinary catheter; immune disorders; } \\
\text { alteration of creatinine, transaminases or bilirubin values } \\
\text { Study discontinuations: } \mathrm{n}=4 \\
\text { GROUP } 1, \mathrm{n}=2 \text { (of which } 1 \text { available at follow-up) } \\
\text { GROUP } 2, \mathrm{n}=2 \text { (of which } 1 \text { available at follow-up) } \\
\text { Study duration: }-162 \text { days ( } 6 \text { weeks, treatment; } 4 \text { months, follow-up) }\end{array}$ \\
\hline Interventions & $\begin{array}{l}\text { GROUP } 1 \\
\text { Lomefloxacin, oral, } 400 \mathrm{mg} \text { once daily, for } 42 \text { days } \\
\text { GROUP } 2 \\
\text { Trimethoprim-sulfamethoxazole, oral, } 160+800 \mathrm{mg} \text { twice daily, for } 42 \text { days }\end{array}$ \\
\hline Outcomes & $\begin{array}{l}\text { Microbiological eradication per patient and per pathogen } \\
\text { Clinical success (cure/improvement) } \\
\text { Adverse effects of treatment }\end{array}$ \\
\hline
\end{tabular}

Risk of bias

Bias

Authors' judgement

Support for judgement 
Bustillo 1997 (Continued)

\begin{tabular}{|c|c|c|}
\hline $\begin{array}{l}\text { Random sequence generation (selection } \\
\text { bias) }\end{array}$ & High risk & $\begin{array}{l}\text { Sequence generation procedure not dis- } \\
\text { closed }\end{array}$ \\
\hline Allocation concealment (selection bias) & Unclear risk & $\begin{array}{l}\text { Allocation concealment procedure not de- } \\
\text { scribed in study report }\end{array}$ \\
\hline $\begin{array}{l}\text { Blinding of participants and personnel } \\
\text { (performance bias) } \\
\text { All outcomes }\end{array}$ & High risk & $\begin{array}{l}\text { Primary clinical outcome of this open-label } \\
\text { study is subjective }\end{array}$ \\
\hline $\begin{array}{l}\text { Blinding of outcome assessment (detection } \\
\text { bias) } \\
\text { All outcomes }\end{array}$ & Unclear risk & Not disclosed \\
\hline $\begin{array}{l}\text { Incomplete outcome data (attrition bias) } \\
\text { All outcomes }\end{array}$ & Low risk & $\begin{array}{l}\text { Dropouts are } 2 \text { and } 2 \text { participants in groups } \\
1 \text { and } 2 \text {, respectively, and expected micro- } \\
\text { biological success is over } 40 \% \text {. High attri- } \\
\text { tion is unlikely }\end{array}$ \\
\hline Selective reporting (reporting bias) & Low risk & \\
\hline Other bias & Low risk & \\
\hline
\end{tabular}

\section{Cai 2009}

Methods

Randomized, parallel group, open-label, active drug-controlled study

Participants

Geographic region: Italy

Eligible participants: $\mathrm{n}=206$

Enrolled participants: $\mathrm{n}=154$

Randomization:

GROUP 1, n = 106

GROUP 2, $\mathrm{n}=37$

Age (mean of overall population): 31.7 years

GROUP $1,30.8$ years

GROUP 2, 31.9 years

Inclusion: diagnosis of CBP (NIH criteria, with history of CBP). Microbiological diagnosis: 4-glass test

Exclusion: < 18 and > 45 years old; prostatitis category I, III or IV (NIH classification); prostate cancer; other genitourinary cancers; anatomical abnormalities of the urinary tract or evidence of other urological diseases; allergy to fluoroquinolones; recent $(<4$ weeks) oral/parenteral treatment or prophylaxis with antibacterials; positive tests for Chlamydia trachomatis, Ureaplasma urealyticum, Neisseria gonorrhoeae, herpes simplex viruses (HSV1, HSV-2) and human papillomavirus; urinary culture positive for multiple pathogens or for fluoroquinolone-resistant pathogens.

Study discontinuations: $\mathrm{n}=11$ (lost to follow-up)

Study duration: 6 months ( 2 weeks treatment; 5 months and 2 weeks follow-up) 


\begin{tabular}{|c|c|c|}
\hline Interventions & \multicolumn{2}{|c|}{$\begin{array}{l}\text { GROUP } 1 \\
\text { Prulifloxacin, oral, } 600 \mathrm{mg} \text { once daily, plus ProstaMEV/FlogMEV (Serenoa repens, oral, } \\
160 \mathrm{mg} \text { once daily; Urtica dioica, oral, } 120 \mathrm{mg} \text { once daily; Curcuma longa, oral, } 200 \mathrm{mg} \\
\text { once daily; quercetin, oral, } 100 \mathrm{mg} \text { once daily), for } 2 \text { weeks } \\
\text { GROUP } 2 \\
\text { Prulifloxacin, oral, } 600 \mathrm{mg} \text { once daily, for } 2 \text { weeks }\end{array}$} \\
\hline Outcomes & \multicolumn{2}{|c|}{$\begin{array}{l}\text { Microbiological eradication per patient } \\
\text { Clinical improvement (NIH-CPSI total score, IPSS, total score) } \\
\text { Adverse effects of treatment }\end{array}$} \\
\hline Notes & \multicolumn{2}{|c|}{$\begin{array}{l}\text { Microbiological tests at end of treatment were performed only in participants showing } \\
\text { clinical symptom relapse. Microbiological efficacy was not evaluable }\end{array}$} \\
\hline \multicolumn{3}{|l|}{ Risk of bias } \\
\hline Bias & Authors' judgement & Support for judgement \\
\hline $\begin{array}{l}\text { Random sequence generation (selection } \\
\text { bias) }\end{array}$ & Unclear risk & $\begin{array}{l}\text { "Patients were randomized at a ratio of } 3: \\
1 \text { ". No additional detail on randomization } \\
\text { procedure provided }\end{array}$ \\
\hline Allocation concealment (selection bias) & Unclear risk & $\begin{array}{l}\text { Allocation concealment procedure not de- } \\
\text { scribed in study report }\end{array}$ \\
\hline $\begin{array}{l}\text { Blinding of participants and personnel } \\
\text { (performance bias) } \\
\text { All outcomes }\end{array}$ & High risk & $\begin{array}{l}\text { Since microbiological evaluation at the end } \\
\text { of therapy was performed only on partici- } \\
\text { pants showing clinical relapse, it does not } \\
\text { represent a study outcome. The only pri- } \\
\text { mary (clinical) outcome of the study was } \\
\text { based on subjective symptom and quality of } \\
\text { life scores. Such evaluations require blind- } \\
\text { ing to minimize bias }\end{array}$ \\
\hline $\begin{array}{l}\text { Blinding of outcome assessment (detection } \\
\text { bias) } \\
\text { All outcomes }\end{array}$ & Unclear risk & Not disclosed \\
\hline $\begin{array}{l}\text { Incomplete outcome data (attrition bias) } \\
\text { All outcomes }\end{array}$ & High risk & $\begin{array}{l}\text { Reasons for withdrawal from study are not } \\
\text { presented separately, according to treat- } \\
\text { ment group }\end{array}$ \\
\hline Selective reporting (reporting bias) & High risk & $\begin{array}{l}\text { Microbiological evaluation at the end of } \\
\text { therapy performed only on participants } \\
\text { showing clinical relapse. Adverse events not } \\
\text { specified in detail (only overall rates dis- } \\
\text { closed) }\end{array}$ \\
\hline
\end{tabular}


Cai 2009 (Continued)

\begin{tabular}{l|l|l}
\hline Other bias & Low risk & No apparent baseline imbalances
\end{tabular}

Cai 2010

Methods

Randomized, parallel group, open-label, active drug-controlled study

Participants

Geographic region: Italy

Enrolled participants: $\mathrm{n}=221$

Randomization:

GROUP 1, n = 117

GROUP 2, n = 104

Age (mean):

GROUP $1,35.2 \pm 7.8$ years

GROUP 2, $33.1 \pm 6.9$ years

Inclusion: diagnosis of CBP; class II (NIH criteria). Infection by Chlamydia trachomatis only. Microbiological diagnosis: 4-glass test.

Exclusion: < 18 and > 45 years old; unspecified comorbidity; recent treatment with antimicrobials (< 4 weeks); anatomical urogenital abnormalities; prostate surgery; allergy to fluoroquinolones; liver/kidney failure

Study discontinuations: $\mathrm{n}=10$

GROUP 1, $\mathrm{n}=8$

GROUP 2, n $=2$

Study duration: 51 days (14 (GROUP 1) or 21 (GROUP 2) days treatment; 30 days follow-up)

Interventions

GROUP 1

Prulifloxacin, oral, $600 \mathrm{mg}$ once daily, for 14 days

GROUP 2

Doxycycline, oral, $100 \mathrm{mg}$ twice daily, for 21 days

Outcomes

Microbiological eradication per patient

Clinical improvement (NIH-CPSI total score, and number of patients with residual symptoms)

Adverse effects of treatment

Notes

Chlamydia infection and resolution of infection tested with a mucosal IgA immunoperoxidase assay at enrolment and at test-of-cure visit (30 days off-therapy). In this review, only participants showing both IgA and DNA findings were evaluated

Risk of bias

\begin{tabular}{|c|c|c|}
\hline Bias & Authors' judgement & Support for judgement \\
\hline $\begin{array}{l}\text { Random sequence generation (selection } \\
\text { bias) }\end{array}$ & Unclear risk & $\begin{array}{l}\text { Sequence generation procedure not speci- } \\
\text { fied. Randomization: } 1: 1\end{array}$ \\
\hline Allocation concealment (selection bias) & Unclear risk & $\begin{array}{l}\text { Allocation concealment procedure not de- } \\
\text { scribed in study report }\end{array}$ \\
\hline
\end{tabular}




\begin{tabular}{|c|c|c|}
\hline $\begin{array}{l}\text { Blinding of participants and personnel } \\
\text { (performance bias) } \\
\text { All outcomes }\end{array}$ & High risk & $\begin{array}{l}\text { Primary clinical outcome (NIH-CPSI } \\
\text { symptom score) of this open-label study is } \\
\text { subjective }\end{array}$ \\
\hline $\begin{array}{l}\text { Blinding of outcome assessment (detection } \\
\text { bias) } \\
\text { All outcomes }\end{array}$ & Unclear risk & Not disclosed \\
\hline $\begin{array}{l}\text { Incomplete outcome data (attrition bias) } \\
\text { All outcomes }\end{array}$ & Low risk & $\begin{array}{l}\text { Dropouts are } 7 \text { and } 2 \% \text { in groups } 1 \text { and } 2 \text {, } \\
\text { respectively, and expected microbiological } \\
\text { success is over } 60 \% \text {. High attrition is un- } \\
\text { likely }\end{array}$ \\
\hline Selective reporting (reporting bias) & Low risk & \\
\hline Other bias & Low risk & No apparent baseline imbalance \\
\hline
\end{tabular}

\section{Cox 1989}

\begin{tabular}{|c|c|}
\hline Methods & Randomized, parallel group, open-label, active drug-controlled, study \\
\hline Participants & $\begin{array}{l}\text { Geographic region: USA } \\
\text { Enrolled participants: } \mathrm{n}=46 \\
\text { Randomization: } \\
\text { GROUP } 1, \mathrm{n}=22 \\
\text { GROUP } 2, \mathrm{n}=24 \\
\text { Age (mean): } \\
\text { GROUP } 1,40.3 \text { years } \\
\text { GROUP } 2,43.2 \text { years } \\
\text { Inclusion: diagnosis of CBP, and history of CBP and urinary tract infection (UTI) } \\
\text { symptoms. Microbiological diagnosis: 4-glass test } \\
\text { Exclusion: < } 18 \text { years old; other criteria not specified } \\
\text { Study discontinuations: } \mathrm{n}=23 \\
\text { GROUP } 1, \mathrm{n}=13 \\
\text { GROUP } 2, \mathrm{n}=10 \\
\text { Study duration: } 11 \text { weeks ( } 6 \text { weeks, treatment; } 5 \text { weeks, follow-up) }\end{array}$ \\
\hline Interventions & $\begin{array}{l}\text { GROUP } 1 \\
\text { Ofloxacin, oral, } 300 \mathrm{mg} \text { twice daily, for } 6 \text { weeks } \\
\text { GROUP } 2 \\
\text { Carbenicillin, oral, } 764 \mathrm{mg} \text { four times daily, for } 6 \text { weeks }\end{array}$ \\
\hline Outcomes & $\begin{array}{l}\text { Microbiological eradication per patient } \\
\text { Clinical improvement (cure/improvement/failure) } \\
\text { Adverse effects of treatment }\end{array}$ \\
\hline
\end{tabular}

Notes 


\section{Cox 1989 (Continued)}

\section{Risk of bias}

\begin{tabular}{|c|c|c|}
\hline Bias & Authors' judgement & Support for judgement \\
\hline $\begin{array}{l}\text { Random sequence generation (selection } \\
\text { bias) }\end{array}$ & Unclear risk & $\begin{array}{l}\text { "Patients were randomly assigned to oral } \\
\text { therapy". Sequence generation procedure } \\
\text { not specified }\end{array}$ \\
\hline Allocation concealment (selection bias) & Unclear risk & $\begin{array}{l}\text { Allocation concealment procedure not de- } \\
\text { scribed in study report }\end{array}$ \\
\hline $\begin{array}{l}\text { Blinding of participants and personnel } \\
\text { (performance bias) } \\
\text { All outcomes }\end{array}$ & High risk & $\begin{array}{l}\text { Primary clinical outcome of this open-label } \\
\text { study is subjective }\end{array}$ \\
\hline $\begin{array}{l}\text { Blinding of outcome assessment (detection } \\
\text { bias) } \\
\text { All outcomes }\end{array}$ & Unclear risk & Not disclosed \\
\hline $\begin{array}{l}\text { Incomplete outcome data (attrition bias) } \\
\text { All outcomes }\end{array}$ & High risk & $\begin{array}{l}\text { High number of dropouts. Eradication } \\
\text { rates expected for the beta-lactam are low } \\
\text { (poor prostate penetration in non-acute pa- } \\
\text { tients) } \\
\text { ITT analysis is missing }\end{array}$ \\
\hline Selective reporting (reporting bias) & High risk & ITT analysis is missing \\
\hline Other bias & High risk & $\begin{array}{l}\text { Questionable study design: patient cohort } \\
\text { may be 'contaminated' by presence of few } \\
\text { patients with acute prostatitis }\end{array}$ \\
\hline
\end{tabular}

Giannarini 2007

Methods

Participants
Randomized, parallel group, double-blind, active drug-controlled study

Geographic region: Italy

Enrolled participants: $\mathrm{n}=96$

Randomization:

GROUP $1, \mathrm{n}=48$

GROUP 2, $\mathrm{n}=48$

Age: 44 years (median), 31 years to 58 years (range)

Inclusion: > 18 years old, history and diagnosis of CBP (NIH criteria). Microbiological diagnosis: 4-glass test

Exclusion: prostate cancer; other genitourinary cancers; liver or kidney failure; neurologic diseases or other diseases affecting bladder function; infections (sexually transmitted diseases (STD)); genitourinary abnormalities; bladder neck obstruction; prostate surgery; hypersensitivity to fluoroquinolones 
Giannarini 2007 (Continued)

Study discontinuations: $\mathrm{n}=3$ (4 more participants lost at follow-up (group 1, $\mathrm{n}=2$; group $2, \mathrm{n}=2)$ )

GROUP $1, \mathrm{n}=2$

GROUP 2, $\mathrm{n}=1$

Study duration: -7 months (4 weeks therapy; 6 months follow-up)

$\begin{array}{ll}\text { Interventions } & \text { GROUP } 1 \\ & \text { Prulifloxacin, oral, } 600 \mathrm{mg} \text { once daily, for } 4 \text { weeks } \\ & \text { GROUP } 2 \\ & \text { Levofloxacin, oral, } 500 \mathrm{mg} \text { once daily, for } 4 \text { weeks }\end{array}$

Outcomes

Microbiological eradication per patient and per pathogen

Clinical improvement (NIH-CPSI total score, and number of participants with residual symptoms at TOC visit)

Adverse effects of treatment

Notes

Risk of bias

\begin{tabular}{|c|c|c|}
\hline Bias & Authors' judgement & Support for judgement \\
\hline $\begin{array}{l}\text { Random sequence generation (selection } \\
\text { bias) }\end{array}$ & Low risk & $\begin{array}{l}\text { "Patients (were) randomized by a com- } \\
\text { puter-generated schedule" }\end{array}$ \\
\hline Allocation concealment (selection bias) & Low risk & $\begin{array}{l}\text { "All tablets were overencapsulated and de- } \\
\text { livered by a specialized research nurse of } \\
\text { the outpatient clinic to maintain double- } \\
\text { blinding". Allocation was likely concealed }\end{array}$ \\
\hline $\begin{array}{l}\text { Blinding of participants and personnel } \\
\text { (performance bias) } \\
\text { All outcomes }\end{array}$ & Low risk & Double-blind study \\
\hline $\begin{array}{l}\text { Blinding of outcome assessment (detection } \\
\text { bias) } \\
\text { All outcomes }\end{array}$ & Low risk & Adequate \\
\hline $\begin{array}{l}\text { Incomplete outcome data (attrition bias) } \\
\text { All outcomes }\end{array}$ & Low risk & $\begin{array}{l}\text { Both drugs are equally active, and belong } \\
\text { to the same drug family. Reasons for partic- } \\
\text { ipant withdrawal are expected to be similar. } \\
\text { Dropouts are } 4.1 \text { and } 2 \% \text { in groups } 1 \text { and } \\
2 \text {, respectively, and expected microbiologi- } \\
\text { cal success is over } 70 \% \text {. Attrition is unlikely }\end{array}$ \\
\hline Selective reporting (reporting bias) & High risk & Clinical outcome at follow-up is unclear \\
\hline Other bias & Low risk & No apparent baseline imbalance \\
\hline
\end{tabular}


Methods

Participants
Randomized, parallel group, open-label, active drug-controlled, study

Geographic region: Brazil

Enrolled participants: $\mathrm{n}=33$

Randomization:

GROUP $1, \mathrm{n}=18$

GROUP 2, $\mathrm{n}=15$

Age (mean): 47 years

Age range: 21 years to 65 years

Inclusion: diagnosis of CBP (NIH criteria). Microbiological diagnosis: 4-glass test

Exclusion: not reported.

Study discontinuations: $\mathrm{n}=0$

Study duration: 7 months and 2 weeks ( 6 weeks, treatment; 6 months, follow-up)

\section{GROUP 1}

Lomefloxacin, oral, $400 \mathrm{mg}$ once daily, for 6 weeks

GROUP 2

Ofloxacin, oral, $200 \mathrm{mg}$ twice daily, for 6 weeks

Microbiological eradication per patient

Adverse effects of treatment
Outcomes

\section{Risk of bias}

\begin{tabular}{|c|c|c|}
\hline Bias & Authors' judgement & Support for judgement \\
\hline $\begin{array}{l}\text { Random sequence generation (selection } \\
\text { bias) }\end{array}$ & High risk & $\begin{array}{l}\text { Sequence generation procedure not ade- } \\
\text { quate }\end{array}$ \\
\hline Allocation concealment (selection bias) & Unclear risk & $\begin{array}{l}\text { Allocation concealment procedure not de- } \\
\text { scribed in study report }\end{array}$ \\
\hline $\begin{array}{l}\text { Blinding of participants and personnel } \\
\text { (performance bias) } \\
\text { All outcomes }\end{array}$ & Low risk & $\begin{array}{l}\text { Primary outcome is not subjective (micro- } \\
\text { biological culture data) }\end{array}$ \\
\hline $\begin{array}{l}\text { Blinding of outcome assessment (detection } \\
\text { bias) } \\
\text { All outcomes }\end{array}$ & Unclear risk & Not disclosed \\
\hline $\begin{array}{l}\text { Incomplete outcome data (attrition bias) } \\
\text { All outcomes }\end{array}$ & Unclear risk & No withdrawals reported in this study \\
\hline Selective reporting (reporting bias) & High risk & $\begin{array}{l}\text { Clinical outcome was not provided. Eradi- } \\
\text { cation data at TOC visit (end of treatment) } \\
\text { not provided }\end{array}$ \\
\hline
\end{tabular}


Koff 1996 (Continued)

\begin{tabular}{|c|c|c|}
\hline Other bias & Unclear risk & $\begin{array}{l}\text { Study methodology not described in suffi- } \\
\text { cient detail }\end{array}$ \\
\hline
\end{tabular}

Naber 2002

Methods

Randomized, parallel group, open-label, active drug-controlled study

Participants

Geographic region: Europe (Germany - UK)

Enrolled participants: $\mathrm{n}=182$

Randomization:

GROUP $1, \mathrm{n}=93$

GROUP 2, $\mathrm{n}=89$

Age (range): 18 years to 70 years

Inclusion: diagnosis of CBP (NIH criteria) and history of CBP and UTI symptoms (> 2 years). Microbiological diagnosis: 4-glass test.

Exclusion: < 18 years old; category I, III or IV prostatitis; prostate cancer; other cancers (genitourinary); other medications (fenbuprofen, sucralfate, anti-acids); comorbidities (kidney or liver impairment); recent prior treatment with antimicrobials; history of tendinitis; hypersensitivity to fluoroquinolones; seizure; resistance to fluoroquinolones; sepsis.

Study discontinuations: $\mathrm{n}=9$ (plus 5 lost during follow-up)

GROUP 1, $\mathrm{n}=5$ (plus 2 lost during follow-up)

GROUP 2, $\mathrm{n}=4$ (plus 3 lost during follow-up)

Study duration: -7 months ( 4 weeks, treatment; 6 months, follow-up)

Interventions

GROUP 1

Lomefloxacin, oral, $400 \mathrm{mg}$ once daily, for 4 weeks

GROUP 2

Ciprofloxacin, oral, $500 \mathrm{mg}$ twice daily, for 4 weeks

Outcomes

Microbiological eradication per patient and per pathogen

Clinical improvement (cure/improvement/failure)

Adverse effects of treatment

Notes

The study contains ITT and per protocol cohorts

\section{Risk of bias}

\begin{tabular}{|c|c|c|}
\hline Bias & Authors' judgement & Support for judgement \\
\hline $\begin{array}{l}\text { Random sequence generation (selection } \\
\text { bias) }\end{array}$ & Low risk & $\begin{array}{l}\text { "Patients were randomized". Author }(\mathrm{KN}) \\
\text { was contacted, and confirmed centralized } \\
\text { randomization procedure }\end{array}$ \\
\hline
\end{tabular}

Allocation concealment (selection bias) Unclear risk

Allocation procedure not specified in report 
Naber 2002 (Continued)

Blinding of participants and personnel High risk (performance bias)

All outcomes

Blinding of outcome assessment (detection Unclear risk bias)

All outcomes

Incomplete outcome data (attrition bias) Low risk

All outcomes

Selective reporting (reporting bias)

Low risk

Low risk

Other bias

Primary clinical outcome (disease symptoms) of this open-label study is subjective

Not specified

Both drugs are equally active, and belong to the same drug family. Reasons for participant withdrawal are expected to be similar. Modified ITT analysis was performed

All study data were disclosed

No baseline imbalance

Ohkawa 1993

Methods

Participants
Randomized, parallel group, open-label, active drug-controlled, study

Geographic region: Japan

Enrolled participants: $\mathrm{n}=18$

Randomization:

GROUP 1, $\mathrm{n}=9$

GROUP 2, $\mathrm{n}=9$

Age (mean): 47.6 years

Inclusion: diagnosis of CBP. Infection by Ureaplasma urealyticum only. (history of CBP, not known). Microbiological diagnosis: 4-glass test

Exclusion: criteria not specified

Study discontinuations: $\mathrm{n}=4$

GROUP $1, \mathrm{n}=2$

GROUP 2, $\mathrm{n}=2$

Study duration: 2 weeks ( 2 weeks, treatment; no follow-up data available)
Interventions

Outcomes

Notes

Risk of bias

\section{GROUP 1}

Ofloxacin, oral, $200 \mathrm{mg}$ thrice daily, for 2 weeks GROUP 2

Minocycline, oral, $100 \mathrm{mg}$ twice daily, for 2 weeks

Microbiological eradication per patient and per pathogen

Clinical improvement (cure/improvement/failure)

Adverse effects of treatment 
Ohkawa 1993 (Continued)

\begin{tabular}{|c|c|c|}
\hline Bias & Authors' judgement & Support for judgement \\
\hline $\begin{array}{l}\text { Random sequence generation (selection } \\
\text { bias) }\end{array}$ & Unclear risk & $\begin{array}{l}\text { "(...) } 18 \text { patients randomly treated with ei- } \\
\text { ther (...) ofloxacin (...) or (...) minocycline". } \\
\text { No additional details disclosed }\end{array}$ \\
\hline Allocation concealment (selection bias) & Unclear risk & $\begin{array}{l}\text { Allocation concealment procedure not de- } \\
\text { scribed in study report }\end{array}$ \\
\hline $\begin{array}{l}\text { Blinding of participants and personnel } \\
\text { (performance bias) } \\
\text { All outcomes }\end{array}$ & High risk & $\begin{array}{l}\text { Primary clinical outcome (disease signs/ } \\
\text { symptoms) of this open-label study is sub- } \\
\text { jective }\end{array}$ \\
\hline $\begin{array}{l}\text { Blinding of outcome assessment (detection } \\
\text { bias) } \\
\text { All outcomes }\end{array}$ & Unclear risk & Not disclosed \\
\hline $\begin{array}{l}\text { Incomplete outcome data (attrition bias) } \\
\text { All outcomes }\end{array}$ & High risk & $\begin{array}{l}\text { High number of withdrawals }(22.2 \%) \text { in } \\
\text { treatment groups. Reasons for withdrawal } \\
\text { not specified }\end{array}$ \\
\hline Selective reporting (reporting bias) & High risk & $\begin{array}{l}\text { Follow-up data are missing. Leukocyte } \\
\text { counts in prostatic fluid post-therapy not } \\
\text { provided }\end{array}$ \\
\hline Other bias & Low risk & \\
\hline
\end{tabular}

\section{Paulson 1986}

Methods

Participants
Randomized, multicentre, parallel group, single-blind, active drug-controlled study. Substudy of a randomized trial including participants with acute and chronic bacterial prostatitis

Geographic region: USA

Enrolled/eligible participants: $\mathrm{n}=88$ (including 44 patients with complete outcome data, showing acute prostatitis $(n=9)$, chronic prostatitis $(n=27)$, and acute exacerbations of chronic prostatitis ( $\mathrm{n}=8)$, and 44 patients excluded from efficacy analysis)

Randomization:

GROUP 1, $\mathrm{n}=10$ per-protocol patients

GROUP 2, $\mathrm{n}=17$ per-protocol patients

Age (mean):

GROUP 1, 47.1 years

GROUP 2, 45.7 years

Age range (overall): 25 years to 71 years

Inclusion: diagnosis of $\mathrm{CBP}$ (with previous history of $\mathrm{CBP}$ ). Microbiological diagnosis: 4-glass test

Exclusion: < 17 years old; prostate cancer; comorbidity (kidney and liver failure); recent $(<10$ weeks) prior treatment with antimicrobials; hypersensitivity to study drugs; 
Paulson 1986 (Continued)

premature termination of the study (dropout); UTIs; general debility; terminal illness; immunoparesis

Study duration: 10 weeks ( 4 weeks, treatment; 6 weeks, follow-up)

Interventions
GROUP 1
Minocycline, oral, $100 \mathrm{mg}$ twice daily, for 4 weeks
GROUP 2
Cephalexin, oral, $500 \mathrm{mg}$ four times a day, for 4 weeks

Outcomes

Microbiological eradication per patient

Clinical improvement (cure/improvement/failure/recurrence)

Notes

Risk of bias

\begin{tabular}{|c|c|c|}
\hline Bias & Authors' judgement & Support for judgement \\
\hline $\begin{array}{l}\text { Random sequence generation (selection } \\
\text { bias) }\end{array}$ & Unclear risk & $\begin{array}{l}\text { "This was a randomized, single-blind, par- } \\
\text { allel-group investigation (...)". Additional } \\
\text { information not provided }\end{array}$ \\
\hline Allocation concealment (selection bias) & Unclear risk & $\begin{array}{l}\text { Allocation concealment procedure not de- } \\
\text { scribed in study report }\end{array}$ \\
\hline $\begin{array}{l}\text { Blinding of participants and personnel } \\
\text { (performance bias) } \\
\text { All outcomes }\end{array}$ & High risk & $\begin{array}{l}\text { Study described as single-blind, but partic- } \\
\text { ipants in group } 1 \text { (active drug twice-daily) } \\
\text { did not receive two additional placebo } \\
\text { tablets, to equal participants in group } 2 \text { (ac- } \\
\text { tive drug } 4 \text { times/day) }\end{array}$ \\
\hline $\begin{array}{l}\text { Blinding of outcome assessment (detection } \\
\text { bias) } \\
\text { All outcomes }\end{array}$ & Unclear risk & Not disclosed \\
\hline $\begin{array}{l}\text { Incomplete outcome data (attrition bias) } \\
\text { All outcomes }\end{array}$ & High risk & $\begin{array}{l}\text { Reasons for withdrawal from study are not } \\
\text { presented separately, according to disease } \\
\text { group (acute prostatitis versus chronic pro- } \\
\text { statitis versus post-chronic, relapsing acute } \\
\text { prostatitis) }\end{array}$ \\
\hline Selective reporting (reporting bias) & High risk & $\begin{array}{l}\text { Eradication per pathogen data are missing. } \\
\text { Adverse effect outcomes not stratified ac- } \\
\text { cording to disease group }\end{array}$ \\
\hline Other bias & High risk & $\begin{array}{l}\text { Due to the peculiar design of the study (par- } \\
\text { ticipants with different conditions pooled } \\
\text { at enrolment) baseline imbalances are not } \\
\text { evaluable }\end{array}$ \\
\hline
\end{tabular}


Skerk 2002

\begin{tabular}{|c|c|}
\hline Methods & Randomized, parallel group, open-label, active drug-controlled, study \\
\hline Participants & $\begin{array}{l}\text { Geographic region: Croatia } \\
\text { Eligible participants: } \mathrm{n}=123 \\
\text { Enrolled participants: } \mathrm{n}=91 \\
\text { Randomization: } \\
\text { GROUP } 1, \mathrm{n}=46 \\
\text { GROUP } 2, \mathrm{n}=45 \\
\text { Age range: } 20 \text { years to } 49 \text { years } \\
\text { Age (mean): } \\
\text { GROUP } 1,38.9 \pm 12.7 \text { years } \\
\text { GROUP } 2,39.2 \pm 12.6 \text { years } \\
\text { Inclusion: diagnosis of CBP (with history of CBP; NIH criteria). Infection by Chlamydia } \\
\text { trachomatis only. Microbiological diagnosis: } 4 \text {-glass test } \\
\text { Exclusion: recent (< } 2 \text { weeks) prior treatment with antimicrobials; hypersensitivity to } \\
\text { macrolides; renal impairment; liver impairment (AST or ALT }>2 X \text { upper limit); chronic } \\
\text { diarrhea or gastrointestinal condition preventing drug absorption } \\
\text { Study discontinuations: } \mathrm{n}=0 \\
\text { Maximum study duration: } 9 \text { weeks (GROUP } 1: 3 \text { weeks, treatment; TOC visit: } 4 \text { to } 6 \\
\text { weeks off-therapy; GROUP } 2: 2 \text { weeks, treatment; TOC visit: } 4 \text { to } 6 \text { weeks off-therapy) }\end{array}$ \\
\hline Interventions & $\begin{array}{l}\text { GROUP } 1 \\
\text { Azithromycin, oral, } 500 \mathrm{mg} \text { once daily, thrice weekly (first three consecutive days of each } \\
\text { week), for } 3 \text { weeks } \\
\text { GROUP } 2 \\
\text { Clarithromycin, oral, } 500 \mathrm{mg} \text { twice daily, for } 2 \text { weeks }\end{array}$ \\
\hline Outcomes & $\begin{array}{l}\text { Microbiological eradication per-patient (evaluated } 4 \text { to } 6 \text { weeks after completion of } \\
\text { treatment) } \\
\text { Clinical improvement (cure/failure) (to be evaluated during treatment, at the end of } \\
\text { treatment and } 4 \text { to } 6 \text { weeks after completion of treatment) } \\
\text { Adverse effects of treatment (to be evaluated during treatment, at the end of treatment } \\
\text { and } 4 \text { to } 6 \text { weeks after completion of treatment) }\end{array}$ \\
\hline Notes & \\
\hline
\end{tabular}

Risk of bias

\begin{tabular}{|c|c|c|}
\hline Bias & Authors' judgement & Support for judgement \\
\hline $\begin{array}{l}\text { Random sequence generation (selection } \\
\text { bias) }\end{array}$ & Low risk & $\begin{array}{l}\text { "Patients were randomized according to a } \\
\text { computerized randomization list" }\end{array}$ \\
\hline Allocation concealment (selection bias) & Unclear risk & $\begin{array}{l}\text { Allocation concealment procedure not de- } \\
\text { scribed in study report. This was a single- } \\
\text { center study; the randomization sequence } \\
\text { was probably generated in the study center }\end{array}$ \\
\hline
\end{tabular}




\section{Skerk 2002 (Continued)}

\begin{tabular}{|c|c|c|}
\hline $\begin{array}{l}\text { Blinding of participants and personnel } \\
\text { (performance bias) } \\
\text { All outcomes }\end{array}$ & High risk & $\begin{array}{l}\text { Primary clinical outcome (disease symp- } \\
\text { toms) of this open-label study is subjective }\end{array}$ \\
\hline $\begin{array}{l}\text { Blinding of outcome assessment (detection } \\
\text { bias) } \\
\text { All outcomes }\end{array}$ & Unclear risk & Not disclosed \\
\hline $\begin{array}{l}\text { Incomplete outcome data (attrition bias) } \\
\text { All outcomes }\end{array}$ & Unclear risk & No withdrawals reported in this study \\
\hline Selective reporting (reporting bias) & High risk & $\begin{array}{l}\text { In methods section authors state: "Clini- } \\
\text { cal efficacy and tolerability (...) as well as } \\
\text { possible adverse events were evaluated dur- } \\
\text { ing, at the end and } 4-6 \text { weeks after comple- } \\
\text { tion of therapy". In results section, the clin- } \\
\text { ical outcome is reported only once, and the } \\
\text { time point for this evaluation is not speci- } \\
\text { fied. Similarly, tolerability data and adverse } \\
\text { event rates are reported only once (time } \\
\text { point: unknown) }\end{array}$ \\
\hline
\end{tabular}

\begin{tabular}{ll} 
Other bias $\quad$ Low risk \\
\hline
\end{tabular}

Skerk 2003

Methods

Participants
Randomized, parallel group, open-label, active drug-controlled study

Geographic region: Croatia

Eligible participants: $\mathrm{n}=89$

Enrolled participants: $\mathrm{n}=89$

Randomization:

GROUP 1, n = 45

GROUP 2, $\mathrm{n}=44$

Age range: 18 years to 69 years

Age (mean):

GROUP $1,40.89 \pm 11.96$ years

GROUP 2, $39.48 \pm 12.75$ years

Inclusion: diagnosis of CBP (with history of CBP; NIH criteria). Infection by Chlamydia trachomatis only. Microbiological diagnosis: 4-glass test

Exclusion: age $<18$ years; recent $(<2$ weeks) prior treatment with antimicrobials; hypersensitivity to fluoroquinolones and macrolides; renal impairment; liver impairment (AST or ALT > 2X upper limit); chronic diarrhea or gastrointestinal condition preventing drug absorption

Study discontinuations: $\mathrm{n}=0$

Maximum study duration: 9 weeks (GROUP 1: 3 weeks, treatment; TOC visit: 4 to 6 weeks off-therapy; GROUP 2: 20 days, treatment; TOC visit: 4 to 6 weeks off-therapy) 
Skerk 2003

\begin{tabular}{ll}
\hline Interventions & $\begin{array}{l}\text { GROUP } 1 \\
\text { Azithromycin, oral, } 500 \mathrm{mg} \text { once daily, thrice weekly (first three consecutive days of each } \\
\text { week), for } 3 \text { weeks } \\
\text { GROUP } 2 \\
\text { Ciprofloxacin, oral, } 500 \mathrm{mg} \text { twice daily, for } 20 \text { days }\end{array}$ \\
\hline Outcomes & $\begin{array}{l}\text { Microbiological eradication per patient (evaluated } 4 \text { to } 6 \text { weeks after completion of } \\
\text { treatment) } \\
\text { Clinical improvement (cure/improvement/failure) (to be evaluated during treatment, at } \\
\text { the end of treatment and } 4 \text { to } 6 \text { weeks after completion of treatment) } \\
\text { Adverse effects of treatment (to be evaluated during treatment, at the end of treatment } \\
\text { and } 4 \text { to } 6 \text { weeks after completion of treatment) }\end{array}$ \\
\hline Notes & \\
\hline
\end{tabular}

Risk of bias

\begin{tabular}{lll}
\hline Bias & Authors' judgement & Support for judgement \\
\hline $\begin{array}{l}\text { Random sequence generation (selection } \\
\text { bias) }\end{array}$ & Low risk & $\begin{array}{l}\text { "Patients were randomized according to a } \\
\text { computerized randomization list" }\end{array}$ \\
\hline
\end{tabular}

Allocation concealment (selection bias) Unclear risk

Allocation concealment procedure not described in study report. This was a singlecenter study; the randomization sequence was probably generated in the study center

Blinding of participants and personnel High risk (performance bias)

Primary clinical outcome (disease sympAll outcomes toms) of this open-label study is subjective

Blinding of outcome assessment (detection Unclear risk

Not disclosed

bias)

All outcomes

\begin{tabular}{|c|c|c|}
\hline $\begin{array}{l}\text { Incomplete outcome data (attrition bias) } \\
\text { All outcomes }\end{array}$ & Unclear risk & No withdrawals reported in this study \\
\hline Selective reporting (reporting bias) & High risk & $\begin{array}{l}\text { In methods section authors state: "Clinical } \\
\text { efficacy and tolerability (...) as well as pos- } \\
\text { sible adverse events were evaluated during, } \\
\text { at the end and } 4 \text { to } 6 \text { weeks after comple- } \\
\text { tion of therapy". In results section, the clin- } \\
\text { ical outcome is reported only once, and the } \\
\text { time point for this evaluation is not speci- } \\
\text { fied. Similarly, tolerability data and adverse } \\
\text { event rates are reported only once (time } \\
\text { point: unknown) }\end{array}$ \\
\hline
\end{tabular}


Skerk 2003

Other bias

Low risk

Skerk 2004a

Methods

Randomized, parallel group, open-label, active drug-controlled, study

Participants

Geographic region: Croatia

Eligible participants: $\mathrm{n}=125$

Enrolled participants: $\mathrm{n}=125$

Randomization:

GROUP $1, \mathrm{n}=82$

GROUP 2, $\mathrm{n}=43$

Age (mean):

GROUP $1,37.5 \pm 12.6$ years

GROUP 2, $32 \pm 10.7$ years

Inclusion: diagnosis of CBP (with history of CBP; NIH criteria). Infection by Chlamydia trachomatis only. Microbiological diagnosis: 4-glass test

Exclusion: age $<18$ years; recent $(<2$ weeks) prior treatment with antimicrobials; hypersensitivity to macrolides and tetracyclines; renal impairment; liver impairment (AST or ALT > 2X upper limit); chronic diarrhea or gastrointestinal condition preventing drug absorption

Study discontinuations: $\mathrm{n}=0$

Maximum study duration: 10 weeks ( 4 weeks, treatment; TOC visit: 4 to 6 weeks offtherapy)

Interventions

GROUP 1

Azithromycin, oral, $1000 \mathrm{mg}$ once weekly, for 4 weeks

GROUP 2

Doxycycline, oral, $100 \mathrm{mg}$ twice daily, for 4 weeks

Outcomes

Microbiological eradication per patient (evaluated 4 to 6 weeks after completion of treatment)

Clinical improvement (cure/improvement/failure) (to be evaluated during treatment, at the end of treatment and 4 to 6 weeks after completion of treatment)

Adverse effects of treatment (to be evaluated during treatment, at the end of treatment and 4 to 6 weeks after completion of treatment)

Notes

Risk of bias

Bias

Random sequence generation (selection Low risk bias)

\section{Authors' judgement}

\section{Support for judgement}

"Patients were randomized according to a computerized randomization list, in the ratio " $2 / 1$ azithromycin/doxycycline" 
Skerk 2004a (Continued)

\begin{tabular}{|c|c|c|}
\hline Allocation concealment (selection bias) & Unclear risk & $\begin{array}{l}\text { Allocation concealment procedure not de- } \\
\text { scribed in study report. This was a single- } \\
\text { center study; the randomization sequence } \\
\text { was probably generated in the study center }\end{array}$ \\
\hline $\begin{array}{l}\text { Blinding of participants and personnel } \\
\text { (performance bias) } \\
\text { All outcomes }\end{array}$ & High risk & $\begin{array}{l}\text { Primary clinical outcome (disease symp- } \\
\text { toms) of this open-label study is subjective }\end{array}$ \\
\hline $\begin{array}{l}\text { Blinding of outcome assessment (detection } \\
\text { bias) } \\
\text { All outcomes }\end{array}$ & Unclear risk & Not disclosed \\
\hline $\begin{array}{l}\text { Incomplete outcome data (attrition bias) } \\
\text { All outcomes }\end{array}$ & Unclear risk & No withdrawals reported in this study \\
\hline Selective reporting (reporting bias) & High risk & $\begin{array}{l}\text { In methods section authors state: "Clini- } \\
\text { cal efficacy and tolerability (...) as well as } \\
\text { possible adverse events were evaluated dur- } \\
\text { ing, at the end and } 4-6 \text { weeks after comple- } \\
\text { tion of therapy". In results section, the clin- } \\
\text { ical outcome is reported only once, and the } \\
\text { time point for this evaluation is not speci- } \\
\text { fied. Similarly, tolerability data and adverse } \\
\text { event rates are reported only once (time } \\
\text { point: unknown) }\end{array}$ \\
\hline Other bias & Low risk & \\
\hline
\end{tabular}

Skerk 2004b

Methods

Randomized, parallel group, open-label, active drug-controlled, study

Participants

Geographic region: Croatia

Eligible participants: $n=209$

Enrolled participants: $\mathrm{n}=89$

Randomization:

GROUP $1, \mathrm{n}=46$

GROUP 2, $\mathrm{n}=43$

Age (mean):

GROUP $1,39 \pm 10.24$ years

GROUP 2, $33 \pm 8.98$ years

Inclusion: diagnosis of CBP (with history of CBP; NIH criteria). Infection by Chlamydia trachomatis only. Microbiological diagnosis: 4-glass test

Exclusion: age $<18$ years; recent $(<2$ weeks) prior treatment with antimicrobials; hypersensitivity to macrolides; renal impairment; liver impairment (AST or ALT $>2 \mathrm{X}$ upper limit); chronic diarrhea or gastrointestinal condition preventing drug absorption Study discontinuations: $\mathrm{n}=0$ 
Maximum study duration: 10 weeks (GROUP 1: 3 weeks, treatment; GROUP 2: 4 weeks, treatment; TOC visit: 4 to 6 weeks off-therapy)

\begin{tabular}{ll} 
Interventions & $\begin{array}{l}\text { GROUP } 1 \\
\text { Azithromycin, oral, } 500 \mathrm{mg} \text { once daily, thrice weekly (first three consecutive days of each } \\
\text { week), for } 3 \text { weeks } \\
\text { GROUP } 2 \\
\text { Azithromycin, oral, } 500 \mathrm{mg} \text { once daily, thrice weekly (first three consecutive days of each } \\
\text { week), for } 4 \text { weeks }\end{array}$ \\
\hline Outcomes & $\begin{array}{l}\text { Microbiological eradication per-patient (evaluated } 4 \text { to } 6 \text { weeks after completion of } \\
\text { treatment) } \\
\text { Clinical improvement (cure/failure) (to be evaluated during treatment, at the end of } \\
\text { treatment and } 4 \text { to } 6 \text { weeks after completion of treatment) } \\
\text { Adverse effects of treatment (to be evaluated during treatment, at the end of treatment } \\
\text { and } 4 \text { to } 6 \text { weeks after completion of treatment) }\end{array}$ \\
\hline Notes & \\
\hline
\end{tabular}

\section{Risk of bias}

\begin{tabular}{|c|c|c|}
\hline Bias & Authors' judgement & Support for judgement \\
\hline $\begin{array}{l}\text { Random sequence generation (selection } \\
\text { bias) }\end{array}$ & Low risk & $\begin{array}{l}\text { "Patients were randomized according to a } \\
\text { computerized randomization list" }\end{array}$ \\
\hline Allocation concealment (selection bias) & Unclear risk & $\begin{array}{l}\text { Allocation concealment procedure not de- } \\
\text { scribed in study report. This was a single- } \\
\text { center study; the randomization sequence } \\
\text { was probably generated in the study center }\end{array}$ \\
\hline $\begin{array}{l}\text { Blinding of participants and personnel } \\
\text { (performance bias) } \\
\text { All outcomes }\end{array}$ & High risk & $\begin{array}{l}\text { Primary clinical outcome (disease symp- } \\
\text { toms) of this open-label study is subjective }\end{array}$ \\
\hline $\begin{array}{l}\text { Blinding of outcome assessment (detection } \\
\text { bias) } \\
\text { All outcomes }\end{array}$ & Unclear risk & Not disclosed \\
\hline $\begin{array}{l}\text { Incomplete outcome data (attrition bias) } \\
\text { All outcomes }\end{array}$ & Unclear risk & No withdrawals reported in this study \\
\hline Selective reporting (reporting bias) & High risk & $\begin{array}{l}\text { In methods section authors state: "Clini- } \\
\text { cal efficacy and tolerability (...) as well as } \\
\text { possible adverse events were evaluated dur- } \\
\text { ing, at the end and } 4-6 \text { weeks after comple- } \\
\text { tion of therapy". In results section, the clin- } \\
\text { ical outcome is reported only once, and the } \\
\text { time point for this evaluation is not speci- }\end{array}$ \\
\hline
\end{tabular}


Skerk 2004b (Continued)

fied. Similarly, tolerability data and adverse event rates are reported only once (time point: unknown)

Other bias Low risk

Skerk 2006

\begin{tabular}{|c|c|}
\hline Methods & Randomized, parallel group, open-label, active drug-controlled, study \\
\hline Participants & $\begin{array}{l}\text { Geographic region: Croatia } \\
\text { Enrolled participants: } \mathrm{n}=63 \\
\text { Randomization: } \\
\text { GROUP } 1, \mathrm{n}=32 \\
\text { GROUP } 2, \mathrm{n}=31 \\
\text { Age (mean): } \\
\text { GROUP } 1,38.2 \pm 9.96 \text { years } \\
\text { GROUP } 2,38.1 \pm 9.95 \text { years } \\
\text { Inclusion: diagnosis of CBP (with history of CBP; NIH criteria). Infection by Ureaplasma } \\
\text { urealyticum (UU) (> } 104 \text { color-changing units UU/mL of EPS/VB3). Absence of UU } \\
\text { from urethral swabs. Absence of other CBP pathogens from urethral swabs, VB1, VB2, } \\
\text { EPS or VB3 specimens. Microbiological diagnosis: } 4 \text {-glass test } \\
\text { Exclusion: age < } 18 \text { years; infection by pathogens other than } U \text {. urealyticum } \\
\text { Study discontinuations: } \mathrm{n}=0 \\
\text { Maximum study duration: } 9 \text { weeks ( } 3 \text { weeks, treatment; TOC visit: } 4 \text { to } 6 \text { weeks off- } \\
\text { therapy) }\end{array}$ \\
\hline Interventions & $\begin{array}{l}\text { GROUP } 1 \\
\text { Azithromycin, oral, } 500 \mathrm{mg} \text { once daily, thrice weekly (first three consecutive days of each } \\
\text { week), for } 3 \text { weeks } \\
\text { GROUP } 2 \\
\text { Doxycycline, oral, } 100 \mathrm{mg} \text { twice daily, for } 3 \text { weeks }\end{array}$ \\
\hline
\end{tabular}

Outcomes

Microbiological eradication per patient

Clinical improvement (clinical cure) (to be evaluated during treatment, at the end of treatment and 4 to 6 weeks after completion of treatment)

Adverse effects of treatment (to be evaluated during treatment, at the end of treatment and 4 to 6 weeks after completion of treatment)

Notes

Risk of bias

\begin{tabular}{|c|c|c|}
\hline Bias & Authors' judgement & Support for judgement \\
\hline $\begin{array}{l}\text { Random sequence generation (selection } \\
\text { bias) }\end{array}$ & Low risk & $\begin{array}{l}\text { "Patients were randomized according to a } \\
\text { computerized randomization list" }\end{array}$ \\
\hline
\end{tabular}




\section{Skerk 2006 (Continued)}

\begin{tabular}{|c|c|c|}
\hline Allocation concealment (selection bias) & Unclear risk & $\begin{array}{l}\text { Allocation concealment procedure not de- } \\
\text { scribed in study report. This was a single- } \\
\text { center study; the randomization sequence } \\
\text { was probably generated in the study center }\end{array}$ \\
\hline $\begin{array}{l}\text { Blinding of participants and personnel } \\
\text { (performance bias) } \\
\text { All outcomes }\end{array}$ & High risk & $\begin{array}{l}\text { Primary clinical outcome (disease symp- } \\
\text { toms) of this open-label study is subjective }\end{array}$ \\
\hline $\begin{array}{l}\text { Blinding of outcome assessment (detection } \\
\text { bias) } \\
\text { All outcomes }\end{array}$ & Unclear risk & Not disclosed \\
\hline $\begin{array}{l}\text { Incomplete outcome data (attrition bias) } \\
\text { All outcomes }\end{array}$ & Unclear risk & No withdrawals reported in this study \\
\hline Selective reporting (reporting bias) & High risk & $\begin{array}{l}\text { In methods section authors state: "Clini- } \\
\text { cal efficacy and tolerability (...) as well as } \\
\text { possible adverse events were evaluated dur- } \\
\text { ing, at the end and } 4-6 \text { weeks after comple- } \\
\text { tion of therapy". In results section, the clin- } \\
\text { ical outcome is reported only once, and the } \\
\text { time point for this evaluation is not speci- } \\
\text { fied. Similarly, tolerability data and adverse } \\
\text { event rates are reported only once (time } \\
\text { point: unknown) }\end{array}$ \\
\hline Other bias & Low risk & \\
\hline
\end{tabular}

\section{Smith 1979}

Methods

Participants
Randomized, double-blind, parallel group trial

Geographic region: North America/Sweden

Eligible participants: $\mathrm{n}=46$

Enrolled participants: $\mathrm{n}=38$

Randomization:

GROUP $1, \mathrm{n}=20$

GROUP 2, $\mathrm{n}=18$

Age (median): 69 years (range: 41 years to 88 years)

Inclusion: bacteriuria (> 100,000 CFU/mL Enterobacteriaceae) and 2 previous episodes of infection. Microbiological diagnosis: 4-glass test

Exclusion: liver impairment (AST or ALT > 2X upper limit), hematopoietic disease, systemic lupus erythematosus, any disease with life expectancy $<6$ months, kidney impairment (serum creatinine $>2.1 \mathrm{mg} / \mathrm{dL}$ ), calculosis, allergy to co-trimoxazole, resistance of isolates to co-trimoxazole, unwillingness to be compliant

Study discontinuations:

GROUP 1, n = 5 
Smith 1979 (Continued)

GROUP 2, $\mathrm{n}=3$

Maximum study duration: 12 weeks

\begin{tabular}{ll} 
Interventions & $\begin{array}{l}\text { GROUP } 1 \\
\text { Co-trimoxazole, oral, } 480 \mathrm{mg} \text { ( } 400 \mathrm{mg} \text { sulfamethoxazole; } 80 \mathrm{mg} \text { trimethoprim) twice } \\
\text { daily, for } 10 \text { days } \\
\text { GROUP } 2 \\
\text { Co-trimoxazole, oral, } 480 \mathrm{mg} \text { twice daily, for } 12 \text { weeks (participants were pre-treated } \\
\text { with } 100 \mathrm{mg} \text { nitrofurantoin four times/day for } 3 \text { days prior to 4-glass test) }\end{array}$ \\
\hline Outcomes & $\begin{array}{l}\text { Microbiological eradication per patient } \\
\text { Adverse effects of treatment }\end{array}$ \\
\hline Notes & \\
\hline
\end{tabular}

Risk of bias

\begin{tabular}{l|ll}
\hline Bias & Authors' judgement & Support for judgement \\
\hline $\begin{array}{l}\text { Random sequence generation (selection } \\
\text { bias) }\end{array}$ & Unclear risk & Randomization system not disclosed \\
\hline Allocation concealment (selection bias) & Unclear risk & Not disclosed \\
\hline $\begin{array}{l}\text { Blinding of participants and personnel } \\
\text { (performance bias) } \\
\text { All outcomes }\end{array}$ & Low risk & Double-blind study \\
\hline
\end{tabular}

Blinding of outcome assessment (detection Low risk bias)

All outcomes

Incomplete outcome data (attrition bias) High risk All outcomes

Selective reporting (reporting bias)

Unclear risk

Low risk

Other bias
Microbiological eradication as sole outcome. Detection bias is low, due to the nonsubjective nature of the outcome

High number of withdrawals in treatment groups, and low expected therapeutic success indicate high attrition bias

A clinical assessment section is absent

Zhang 2012

Methods

Participants
Randomized, open-label, parallel group trial

Geographic region: China

Enrolled participants: $\mathrm{n}=408$

Randomization:

GROUP 1, n = 209 


\begin{tabular}{|c|c|}
\hline & $\begin{array}{l}\text { GROUP 2, } \mathrm{n}=199 \\
\text { Age (mean): } \\
\text { Overall, } 33.8 \pm 9.2 \text { years (range: } 19 \text { years to } 54 \text { years) } \\
\text { GROUP } 1,33.4 \pm 8.1 \text { years } \\
\text { GROUP } 2,33.5 \pm 8.5 \text { years } \\
\text { Inclusion: diagnosis of CBP (with history and signs/symptoms of CBP) } \\
\text { Exclusion: age < } 18 \text { years; comorbidities (heart, liver, lung, or kidney failure); psychotic } \\
\text { disorders, severe benign prostatic hyperplasia } \\
\text { Study discontinuations: } \mathrm{n}=0 \\
\text { Maximum study duration: }-7 \text { months and } 1 \text { week ( } 4 \text { weeks, treatment; TOC visit: } 1 \\
\text { week off therapy; follow-up: } 6 \text { months) }\end{array}$ \\
\hline Interventions & $\begin{array}{l}\text { GROUP } 1 \\
\text { Levofloxacin, oral, } 500 \mathrm{mg} \text { once daily, for } 4 \text { weeks } \\
\text { GROUP } 2 \\
\text { Ciprofloxacin, oral, } 500 \mathrm{mg} \text { twice daily, for } 4 \text { weeks }\end{array}$ \\
\hline Outcomes & $\begin{array}{l}\text { Microbiological eradication per patient } \\
\text { Clinical success (cured/improved) } \\
\text { Adverse effects of treatment }\end{array}$ \\
\hline Notes & Intention-to-treat analysis \\
\hline
\end{tabular}

Risk of bias

\section{Bias}

Random sequence generation (selection Low risk bias)

Allocation concealment (selection bias) Unclear risk

Blinding of participants and personnel High risk (performance bias)

All outcomes

Blinding of outcome assessment (detection Unclear risk bias)

All outcomes

Incomplete outcome data (attrition bias) High risk All outcomes

\section{Support for judgement}

"Patients were randomized (...) using computer-generated random tables for each centre"

\section{Not disclosed}

Primary clinical outcome (disease signs/ symptoms) of this open-label study is subjective

Not disclosed

Quote: "Bacteria were isolated in 209 patients from the levofloxacin-treated group and 199 patients from the ciprofloxacintreated group

A total of $165(78.95 \%)$ and 123 (61. $81 \%)$ patients showed sensitivity to levofloxacin and ciprofloxacin, respectively, and was significantly different between the 
two groups $(\mathrm{p}<0.05 \%)$. (...) At visit 5 , the bacteria clearance rate in those with confirmed bacterial infection was significantly higher in the levofloxacin-treated group (. ..) $[85.65 \%(179 / 209)]$ than in the ciprofloxacin-treated group (...) [60.30\% (120/ 199); $\mathrm{P}<0.05)$ ]"

Comment: Participants with CBP caused by ciprofloxacin-resistant pathogens (almost $40 \%$ of isolated pathogens) were probably treated with ciprofloxacin. Thus, eradication data refer to treatment cohorts containing participants infected by resistant strains. Eradication rates for participants harboring only ciprofloxacin-susceptible pathogens were not disclosed. The levofloxacin-treated cohort contained levofloxacin-resistant CBP cases, too. The fraction of levofloxacin-resistant and ciprofloxacin-resistant cases are unbalanced in treatment cohorts $(21 \%$ and $38.2 \%$, respectively)

No dropouts were reported for a total cohort of 408 participants, and for the intention-to-treat analysis

Selective reporting (reporting bias) High risk

Microbiological findings at follow-up (6 months) not disclosed

Other bias

High risk

The first-voided urine specimen of participants (VB1) was discarded and not sent for microbiological analysis. Thus, the fraction of participants with concomitant urethral infection is unknown

Participants with CBP caused by ciprofloxacin-resistant pathogens (almost $40 \%$ of isolated pathogens were ciprofloxacin-resistant), were nevertheless treated with ciprofloxacin

"Additional agents" were administered in total 42 participants together with antibacterial agents. Name and dosage of these agents, as well as therapy duration were not disclosed. These unspecified drugs may have acted as confounders in microbiological or clinical assessments 
Characteristics of excluded studies [ordered by study ID]

\begin{tabular}{|c|c|}
\hline Study & Reason for exclusion \\
\hline Ateya 2006 & Multiple antimicrobial agents in a single treatment arm. Dosing not disclosed. Subgroup analysis not feasible \\
\hline Baert 1983 & Non-comparative study \\
\hline Barbalias 1998 & $\begin{array}{l}\text { Multiple antimicrobial agents in a single treatment arm. Types, doses and dosing of antimicrobial agents not } \\
\text { disclosed }\end{array}$ \\
\hline Brannan 1975 & Non-randomized study \\
\hline Cai 2011 & Included patients with "genital infection", associated with oligoasthenoteratozoospermia \\
\hline Childs 1983 & $\begin{array}{l}\text { A study focusing on urinary tract infection in men and women, involving a very small fraction }(\mathrm{n}=2) \text { of } \\
\text { patients with CBP }\end{array}$ \\
\hline Colleen 1975 & Non-randomized study \\
\hline Cox 1991 & Not an RCT \\
\hline Deng 2004 & Lower urinary tract segmented test not defined. Doses and dosing of antimicrobial agents not clearly defined \\
\hline Gleckman 1979 & A randomized study focusing on bacteriuria, possibly involving an undefined fraction of patients with CBP \\
\hline Hu 2002 & Lower urinary tract segmented test not clearly defined \\
\hline Kim 2006 & This study pooled patients with prostatitis and prostato-vesiculitis/vesiculitis \\
\hline Kozdoba 2007 & Non-randomized study \\
\hline Kunishima 2008 & Not an RCT \\
\hline Lee 2006 & $\begin{array}{l}\text { Not an RCT. Patients with category II CBP and category III CP/CPPS were pooled in the same treatment } \\
\text { arms }\end{array}$ \\
\hline Liao 2004 & $\begin{array}{l}\text { Involves traditional Chinese medication in combination with "antibacterial treatment" with unspecified an- } \\
\text { tibiotics }\end{array}$ \\
\hline Martino 1993 & The study included patients with category I acute bacterial prostatitis \\
\hline Nickel 2008a & An ancillary study of the Bundrick 2003 trial \\
\hline Paglia 2010 & $\begin{array}{l}\text { In this study a lower urinary tract segmented microbiological test was not required at enrolment, and a past } \\
\text { history of CBP was deemed sufficient to qualify a patient as having CBP }\end{array}$ \\
\hline Panagopoulos 2009 & Not an RCT \\
\hline
\end{tabular}


(Continued)

\begin{tabular}{|c|c|}
\hline Sabbaj 1986 & A randomized study including men with recurrent UTI with or without a history of CBP \\
\hline Schaeffer 2005 & An ancillary study of the Bundrick 2003 trial \\
\hline Shafik 1992 & Not an RCT \\
\hline Shen 2004 & $\begin{array}{l}\text { Randomized population included patients with category II CBP or category III CP/CPPS. Subgroup analysis } \\
\text { of patient population not feasible }\end{array}$ \\
\hline Smelov 2004 & Non-randomized study \\
\hline Trapeznikova 2007 & Doses and dosage of antimicrobial agents not disclosed \\
\hline Vicari 2000 & $\begin{array}{l}\text { Patients were not diagnosed with a lower urinary tract segmented test and were not divided into separate } \\
\text { treatment groups }\end{array}$ \\
\hline Vickovic 2010 & This study was performed on patients with protozoans as etiological determinants of chronic prostatitis \\
\hline Wedren 1989 & $\begin{array}{l}\text { Outcomes from treatment arms (cephalosporin versus co-trimoxazole) not presented separately. Non-compar- } \\
\text { ative study }\end{array}$ \\
\hline Xu 2010 & Involves traditional Chinese medication (Qianlie-Jedu) \\
\hline Yavaçaoğ lu 1998 & $\begin{array}{l}\text { Comparison is between different techniques of intraprostatic administration. Route, drug and dosing are } \\
\text { identical }\end{array}$ \\
\hline Zhang 2004 & $\begin{array}{l}\text { Involves traditional Chinese medication. In patients "chronic prostatitis" could be associated or not with } \\
\text { urethritis }\end{array}$ \\
\hline
\end{tabular}

Characteristics of studies awaiting assessment [ordered by study ID]

\section{Drasa 2009}

\begin{tabular}{ll} 
Methods & Prospective, randomized, double-blind trial \\
\hline Participants & Geographic region: Albania \\
& Enrolled participants: $\mathrm{n}=123$ \\
& Randomization: \\
& GROUP 1, $\mathrm{n}=41$ \\
& GROUP 2, $\mathrm{n}=41$ \\
& GROUP 3, $\mathrm{n}=41$ \\
& Age (mean, overall): unknown \\
& Age range: unknown \\
& Inclusion: “clinical diagnosis of CBP”. Microbiological diagnosis: Meares-Stamey test \\
& Exclusion criteria: unknown \\
& Study discontinuations: $\mathrm{n}=$ unknown
\end{tabular}


Study duration: treatment, 10 days, follow-up, 6 months

\begin{tabular}{ll} 
Interventions & $\begin{array}{l}\text { GROUP } 1 \\
\text { Cefuroxime axetil } 500 \mathrm{mg} \text { ("parenteral”?) twice daily for } 10 \text { days, and subsequently once daily for } 10 \text { days } \\
\text { GROUP } 2 \\
\text { Ceftriaxone } 1000 \mathrm{mg}, \text { "parenteral”, twice daily for } 10 \text { days } \\
\text { GROUP } 3 \\
\text { Ceftriaxone } 1000 \mathrm{mg}, \text { "parenteral”, twice daily for } 10 \text { days, and subsequently cefuroxime axetil } 500 \mathrm{mg} \text {, twice daily } \\
\text { for } 10 \text { days, and subsequently cefuroxime axetil, once daily for } 10 \text { days }\end{array}$ \\
\hline Outcomes & $\begin{array}{l}\text { Microbiological eradication } \\
\text { Clinical improvement, assessed with the "validated CBPSI" test }\end{array}$ \\
\hline Notes & $\begin{array}{l}\text { Demographic data are missing. Study withdrawal data are missing. Results concerning the "CBPSI" are verbally } \\
\text { described in text (“At the end of the treatment the clinical improvement based on the CBPSI was a small difference } \\
\text { between the first and the second group, but for the third group was maximally reduce of (sic) the CBPSI”) but scores } \\
\text { or other numerical data are missing. Published report of this study could not be retrieved }\end{array}$ \\
\hline
\end{tabular}


DATA ANDANALYSES

Comparison 1. Different fluoroquinolones: levofloxacin versus ciprofloxacin

\begin{tabular}{|c|c|c|c|c|}
\hline Outcome or subgroup title & $\begin{array}{l}\text { No. of } \\
\text { studies }\end{array}$ & $\begin{array}{c}\text { No. of } \\
\text { participants }\end{array}$ & Statistical method & Effect size \\
\hline $\begin{array}{l}1 \text { Microbiological efficacy } \\
\text { - pathogen eradication } \\
\text { (fixed-effect model) }\end{array}$ & 2 & 669 & Risk Ratio (M-H, Fixed, 95\% CI) & $1.22[1.11,1.34]$ \\
\hline $\begin{array}{l}2 \text { Microbiological efficacy } \\
\text { - pathogen eradication } \\
\text { (random-effects model) }\end{array}$ & 2 & 669 & Risk Ratio (M-H, Random, 95\% CI) & $1.18[0.81,1.71]$ \\
\hline 3 Clinical efficacy & 2 & & Risk Ratio (M-H, Random, 95\% CI) & Subtotals only \\
\hline $\begin{array}{l}3.1 \text { Clinical efficacy (cure or } \\
\text { improvement) at the end of } \\
\text { treatment }\end{array}$ & 2 & 669 & Risk Ratio (M-H, Random, 95\% CI) & $1.16[0.93,1.46]$ \\
\hline $\begin{array}{l}3.2 \text { Clinical efficacy (cure or } \\
\text { improvement) at follow-up ( } 6 \\
\text { months) }\end{array}$ & 2 & 669 & Risk Ratio (M-H, Random, 95\% CI) & $1.16[0.86,1.55]$ \\
\hline 4 Adverse effects of treatment & 2 & & Risk Ratio (M-H, Random, 95\% CI) & Subtotals only \\
\hline 4.1 Any adverse effects & 2 & 785 & Risk Ratio (M-H, Random, 95\% CI) & $0.86[0.70,1.06]$ \\
\hline $\begin{array}{l}4.2 \text { Gastrointestinal adverse } \\
\text { effects }\end{array}$ & 2 & 785 & Risk Ratio (M-H, Random, 95\% CI) & $0.86[0.42,1.77]$ \\
\hline 4.3 Back pain & 1 & 377 & Risk Ratio (M-H, Random, 95\% CI) & $0.55[0.13,2.26]$ \\
\hline 4.4 Headache & 2 & 785 & Risk Ratio (M-H, Random, 95\% CI) & $0.83[0.39,1.76]$ \\
\hline 4.5 Dizziness & 2 & 785 & Risk Ratio (M-H, Random, 95\% CI) & $0.66[0.02,22.13]$ \\
\hline 4.6 Arthralgia & 1 & 377 & Risk Ratio (M-H, Random, 95\% CI) & $1.46[0.49,4.39]$ \\
\hline 4.7 Myalgia & 1 & 377 & Risk Ratio (M-H, Random, 95\% CI) & $1.07[0.37,3.11]$ \\
\hline 4.8 Skeletal pain & 1 & 377 & Risk Ratio (M-H, Random, 95\% CI) & $0.55[0.13,2.26]$ \\
\hline 4.9 Rhinitis & 1 & 377 & Risk Ratio (M-H, Random, 95\% CI) & $0.91[0.27,3.10]$ \\
\hline $\begin{array}{l}4.10 \text { Upper respiratory tract } \\
\text { infection }\end{array}$ & 1 & 377 & Risk Ratio (M-H, Random, 95\% CI) & $1.14[0.31,4.19]$ \\
\hline 4.11 Dermal toxicity & 2 & 785 & Risk Ratio (M-H, Random, 95\% CI) & $0.47[0.12,1.90]$ \\
\hline $\begin{array}{l}4.12 \text { Allergy to experimental } \\
\text { agents }\end{array}$ & 1 & 408 & Risk Ratio (M-H, Random, 95\% CI) & $2.86[0.12,69.73]$ \\
\hline 4.13 Leukopenia & 1 & 408 & Risk Ratio (M-H, Random, 95\% CI) & $0.32[0.01,7.75]$ \\
\hline 4.14 Cough & 1 & 408 & Risk Ratio (M-H, Random, 95\% CI) & $2.86[0.12,69.73]$ \\
\hline 4.15 Insomnia & 1 & 408 & Risk Ratio (M-H, Random, 95\% CI) & $0.48[0.04,5.21]$ \\
\hline $\begin{array}{l}4.16 \text { Altered transaminase } \\
\text { levels }\end{array}$ & 1 & 408 & Risk Ratio (M-H, Random, 95\% CI) & $0.48[0.04,5.21]$ \\
\hline
\end{tabular}




\begin{tabular}{|c|c|c|c|c|}
\hline Outcome or subgroup title & $\begin{array}{l}\text { No. of } \\
\text { studies }\end{array}$ & $\begin{array}{c}\text { No. of } \\
\text { participants }\end{array}$ & Statistical method & Effect size \\
\hline $\begin{array}{l}1 \text { Microbiological efficacy - } \\
\text { pathogen eradication }\end{array}$ & 1 & 89 & Risk Ratio (M-H, Fixed, 95\% CI) & $1.02[0.79,1.33]$ \\
\hline $\begin{array}{l}2 \text { Clinical efficacy - NIH-CPSI } \\
\text { total score at the end of } \\
\text { treatment }\end{array}$ & 1 & 89 & Std. Mean Difference (IV, Random, 95\% CI) & $-0.03[-0.45,0.39]$ \\
\hline 3 Adverse effects of treatment & 1 & & Risk Ratio (M-H, Random, 95\% CI) & Subtotals only \\
\hline 3.1 Any adverse effects & 1 & 89 & Risk Ratio (M-H, Random, 95\% CI) & $0.82[0.36,1.88]$ \\
\hline $\begin{array}{l}3.2 \text { Gastrointestinal adverse } \\
\text { effects }\end{array}$ & 1 & 89 & Risk Ratio (M-H, Random, 95\% CI) & $0.73[0.25,2.13]$ \\
\hline 3.3 Dermal toxicity & 1 & 89 & Risk Ratio (M-H, Random, 95\% CI) & $7.16[0.38,134.62]$ \\
\hline 3.4 Headache & 1 & 89 & Risk Ratio (M-H, Random, 95\% CI) & $0.15[0.01,2.75]$ \\
\hline
\end{tabular}

\section{Comparison 3. Different fluoroquinolones: lomefloxacin versus ofloxacin}

\begin{tabular}{|c|c|c|c|c|}
\hline Outcome or subgroup title & $\begin{array}{l}\text { No. of } \\
\text { studies }\end{array}$ & $\begin{array}{c}\text { No. of } \\
\text { participants }\end{array}$ & Statistical method & Effect size \\
\hline $\begin{array}{l}1 \text { Microbiological efficacy - } \\
\text { pathogen eradication at } \\
\text { follow-up ( } 6 \text { months) }\end{array}$ & 1 & 33 & Risk Ratio (M-H, Fixed, 95\% CI) & $1.11[0.66,1.88]$ \\
\hline 2 Adverse effects of treatment & 1 & & Risk Ratio (M-H, Random, 95\% CI) & Subtotals only \\
\hline 2.1 Any adverse effects & 1 & 33 & Risk Ratio (M-H, Random, 95\% CI) & $0.42[0.16,1.12]$ \\
\hline $\begin{array}{l}2.2 \text { Gastrointestinal adverse } \\
\text { effects }\end{array}$ & 1 & 33 & Risk Ratio (M-H, Random, 95\% CI) & $0.56[0.19,1.61]$ \\
\hline 2.3 Headache & 1 & 33 & Risk Ratio (M-H, Random, 95\% CI) & $0.28[0.01,6.43]$ \\
\hline 2.4 Dizziness & 1 & 33 & Risk Ratio (M-H, Random, 95\% CI) & $0.28[0.01,6.43]$ \\
\hline
\end{tabular}

Comparison 4. Different fluoroquinolones: lomefloxacin versus ciprofloxacin

\begin{tabular}{lcccc} 
Outcome or subgroup title & $\begin{array}{c}\text { No. of } \\
\text { studies }\end{array}$ & $\begin{array}{c}\text { No. of } \\
\text { participants }\end{array}$ & Statistical method & Effect size \\
\hline $\begin{array}{l}\text { 1 Microbiological efficacy } \\
\text { (intention-to-treat analysis) }\end{array}$ & 1 & & Risk Ratio (M-H, Fixed, 95\% CI) & Subtotals only \\
$\quad \begin{array}{l}1.1 \text { Microbiological efficacy } \\
\text { (pathogen eradication) at the }\end{array}$ & 1 & 182 & Risk Ratio (M-H, Fixed, 95\% CI) & $0.96[0.82,1.11]$ \\
$\quad \begin{array}{l}\text { end of treatment } \\
\quad 1.2 \text { Microbiological efficacy }\end{array}$ & 1 & 182 & Risk Ratio (M-H, Fixed, 95\% CI) & $0.87[0.72,1.06]$ \\
$\quad \begin{array}{l}\text { (pathogen eradication) at } \\
\text { follow-up (4 weeks) }\end{array}$ & & & & \\
\hline
\end{tabular}

Antimicrobial therapy for chronic bacterial prostatitis (Review)

Copyright $\odot 2013$ The Cochrane Collaboration. Published by John Wiley \& Sons, Ltd. 
1.3 Microbiological efficacy

(pathogen eradication) at

follow-up (3 months)

1.4 Microbiological efficacy

(pathogen eradication) at

follow-up (6 months)

2 Microbiological efficacy

(per-protocol analysis)

2.1 Microbiological efficacy

(pathogen eradication and

eradication plus superinfection)

at the end of treatment

2.2 Microbiological efficacy

(pathogen eradication and

eradication plus superinfection)

at follow-up (4 weeks)

2.3 Microbiological efficacy

(pathogen eradication and

eradication plus superinfection)

at follow-up (3 months)

2.4 Microbiological efficacy

(pathogen eradication and

eradication plus superinfection)

at follow-up (6 months)

3 Clinical efficacy

(intention-to-treat analysis)

3.1 Clinical efficacy (cure or improvement) at the end of treatment

3.2 Clinical efficacy (cure or improvement) at follow-up (4 weeks)

3.3 Clinical efficacy (cure or improvement) at follow-up (3 months)

3.4 Clinical efficacy (cure or improvement) at follow-up (6 months)

4 Clinical efficacy (per-protocol analysis)

4.1 Clinical efficacy (cure or improvement) at the end of treatment

4.2 Clinical efficacy (cure or improvement) at follow-up (4 weeks)

4.3 Clinical efficacy (cure or improvement) at follow-up (3 months) 
4.4 Clinical efficacy (cure or improvement) at follow-up (6 months)

5 Adverse effects of treatment

5.1 Any adverse effects

5.2 Gastrointestinal adverse effects

5.3 Headache

5.4 Dizziness

5.5 Dry mouth

5.6 Insomnia

5.7 Hyperglycemia

5.8 Dermal toxicity

5.9 Abnormal semen

5.10 Upper respiratory tract infection
Subtotals only

Risk Ratio (M-H, Random, 95\% CI)

$0.82[0.40,1.68]$

182

Risk Ratio (M-H, Random, 95\% CI)

$0.60[0.20,1.76]$

182 Risk Ratio (M-H, Random, 95\% CI)

$0.96[0.06,15.07]$

$2.87[0.12,69.59]$

$4.79[0.23,98.35]$

$0.32[0.01,7.73]$

$2.87[0.12,69.59]$

$2.87[0.12,69.59]$

$2.87[0.12,69.59]$

$0.11[0.01,1.95]$

Comparison 5. Different fluoroquinolones: lomefloxacin versus comparator fluoroquinolone

\begin{tabular}{|c|c|c|c|c|}
\hline Outcome or subgroup title & $\begin{array}{l}\text { No. of } \\
\text { studies }\end{array}$ & $\begin{array}{c}\text { No. of } \\
\text { participants }\end{array}$ & Statistical method & Effect size \\
\hline $\begin{array}{l}1 \text { Microbiological efficacy - } \\
\text { pathogen eradication at } \\
\text { follow-up ( } 6 \text { months) }\end{array}$ & 2 & 116 & Risk Ratio (M-H, Fixed, 95\% CI) & $0.96[0.80,1.16]$ \\
\hline 2 Adverse effects of treatment & 2 & & Risk Ratio (M-H, Random, 95\% CI) & Subtotals only \\
\hline 2.1 Any adverse effects & 2 & 215 & Risk Ratio (M-H, Random, 95\% CI) & $0.64[0.34,1.21]$ \\
\hline $\begin{array}{l}2.2 \text { Gastrointestinal adverse } \\
\text { effects }\end{array}$ & 2 & 215 & Risk Ratio (M-H, Random, 95\% CI) & $0.58[0.27,1.23]$ \\
\hline 2.3 Headache & 2 & 215 & Risk Ratio (M-H, Random, 95\% CI) & $0.56[0.07,4.43]$ \\
\hline 2.4 Dizziness & 2 & 215 & Risk Ratio (M-H, Random, 95\% CI) & $0.88[0.09,8.60]$ \\
\hline
\end{tabular}

Comparison 6. Different fluoroquinolones: ciprofloxacin versus comparator fluoroquinolone

\begin{tabular}{|c|c|c|c|c|}
\hline Outcome or subgroup title & $\begin{array}{l}\text { No. of } \\
\text { studies }\end{array}$ & $\begin{array}{c}\text { No. of } \\
\text { participants }\end{array}$ & Statistical method & Effect size \\
\hline $\begin{array}{l}1 \text { Microbiological efficacy - } \\
\text { pathogen eradication at the } \\
\text { end of treatment (fixed-effect } \\
\text { model) }\end{array}$ & 3 & 851 & Risk Ratio (M-H, Fixed, 95\% CI) & $0.87[0.80,0.94]$ \\
\hline $\begin{array}{l}2 \text { Microbiological efficacy - } \\
\text { pathogen eradication at the end } \\
\text { of treatment (random-effects } \\
\text { model) }\end{array}$ & 3 & & Risk Ratio (M-H, Random, 95\% CI) & Subtotals only \\
\hline 2.1 All studies & 3 & 851 & Risk Ratio (M-H, Random, 95\% CI) & $0.91[0.70,1.18]$ \\
\hline
\end{tabular}


2.2 Sensitivity analysis,

exclusion of Zhang 2012

3 Clinical efficacy

3.1 Clinical efficacy (cure or improvement) at the end of treatment

3.2 Clinical efficacy (cure or improvement) at follow-up (6 months)

4 Adverse effects of treatment

4.1 Any adverse effects

4.2 Gastrointestinal adverse effects

4.3 Headache

4.4 Dizziness

4.5 Dermal toxicity

\section{Comparison 7. Different fluoroquinolones: levofloxacin versus comparator fluoroquinolone}

\begin{tabular}{|c|c|c|c|c|}
\hline Outcome or subgroup title & $\begin{array}{l}\text { No. of } \\
\text { studies }\end{array}$ & $\begin{array}{c}\text { No. of } \\
\text { participants }\end{array}$ & Statistical method & Effect size \\
\hline $\begin{array}{l}1 \text { Microbiological efficacy } \\
\text { - pathogen eradication } \\
\text { (fixed-effect model) }\end{array}$ & 3 & 758 & Risk Ratio (M-H, Fixed, 95\% CI) & $1.19[1.09,1.30]$ \\
\hline $\begin{array}{l}2 \text { Microbiological efficacy } \\
\text { - pathogen eradication } \\
\text { (random-effects model) }\end{array}$ & 3 & & Risk Ratio (M-H, Random, 95\% CI) & Subtotals only \\
\hline 2.1 All studies & 3 & 758 & Risk Ratio (M-H, Random, 95\% CI) & $1.12[0.84,1.48]$ \\
\hline $\begin{array}{l}\text { 2.2 Sensitivity analysis, } \\
\text { exclusion of Zhang } 2012\end{array}$ & 2 & 350 & Risk Ratio (M-H, Random, 95\% CI) & $0.98[0.87,1.10]$ \\
\hline 3 Adverse effects of treatment & 3 & & Risk Ratio (M-H, Random, 95\% CI) & Subtotals only \\
\hline 3.1 Any adverse effects & 3 & 874 & Risk Ratio (M-H, Random, 95\% CI) & $0.88[0.72,1.08]$ \\
\hline $\begin{array}{l}3.2 \text { Gastrointestinal adverse } \\
\text { effects }\end{array}$ & 3 & 874 & Risk Ratio (M-H, Random, 95\% CI) & $1.00[0.69,1.44]$ \\
\hline 3.3 Dermal toxicity & 3 & 874 & Risk Ratio (M-H, Random, 95\% CI) & $0.37[0.11,1.32]$ \\
\hline 3.4 Headache & 3 & 874 & Risk Ratio (M-H, Random, 95\% CI) & $1.00[0.26,3.80]$ \\
\hline
\end{tabular}


Comparison 8. Fluoroquinolone versus other antibacterial agent: prulifloxacin versus doxycycline in chlamydial prostatitis

\begin{tabular}{|c|c|c|c|c|}
\hline Outcome or subgroup title & $\begin{array}{l}\text { No. of } \\
\text { studies }\end{array}$ & $\begin{array}{c}\text { No. of } \\
\text { participants }\end{array}$ & Statistical method & Effect size \\
\hline $\begin{array}{l}1 \text { Microbiological efficacy } \\
\text { - absence of Chlamydia } \\
\text { trachomatis DNA and IgA at } \\
\text { the end of treatment }\end{array}$ & 1 & 38 & Risk Ratio (M-H, Fixed, 95\% CI) & $1.12[0.93,1.36]$ \\
\hline $\begin{array}{l}2 \text { Clinical efficacy - NIH-CPSI } \\
\text { total score at the end of } \\
\text { treatment }\end{array}$ & 1 & 211 & Std. Mean Difference (IV, Random, 95\% CI) & $-0.66[-0.94,-0.39]$ \\
\hline $\begin{array}{l}3 \text { Clinical efficacy - number of } \\
\text { asymptomatic participants at } \\
\text { the end of therapy }\end{array}$ & 1 & 211 & Risk Ratio (M-H, Random, 95\% CI) & $1.04[0.91,1.19]$ \\
\hline 4 Adverse effects of treatment & 1 & & Risk Ratio (M-H, Random, 95\% CI) & Subtotals only \\
\hline 4.1 Any adverse effects & 1 & 211 & Risk Ratio (M-H, Random, 95\% CI) & $1.17[0.32,4.24]$ \\
\hline $\begin{array}{l}4.2 \text { Gastrointestinal adverse } \\
\text { effects }\end{array}$ & 1 & 211 & Risk Ratio (M-H, Random, 95\% CI) & $0.70[0.16,3.06]$ \\
\hline 4.3 Back pain & 1 & 211 & Risk Ratio (M-H, Random, 95\% CI) & $4.68[0.23,96.36]$ \\
\hline
\end{tabular}

Comparison 9. Fluoroquinolone versus other antibacterial agent: ofloxacin versus minocycline in ureaplasmal prostatitis

\begin{tabular}{lcccc} 
Outcome or subgroup title & $\begin{array}{c}\text { No. of } \\
\text { studies }\end{array}$ & $\begin{array}{c}\text { No. of } \\
\text { participants }\end{array}$ & Statistical method & Effect size \\
\hline $\begin{array}{l}\text { 1 Microbiological efficacy - } \\
\text { pathogen eradication }\end{array}$ & 1 & 14 & Risk Ratio (M-H, Fixed, 95\% CI) & $1.0[0.78,1.29]$ \\
$\begin{array}{l}\text { 2 Clinical efficacy (cure or } \\
\text { improvement) at the end of } \\
\text { treatment }\end{array}$ & 1 & 14 & Risk Ratio (M-H, Random, 95\% CI) & $0.87[0.59,1.26]$ \\
\hline
\end{tabular}

Comparison 10. Fluoroquinolone versus other antibacterial agent: ofloxacin versus carbenicillin

\begin{tabular}{|c|c|c|c|c|}
\hline Outcome or subgroup title & $\begin{array}{l}\text { No. of } \\
\text { studies }\end{array}$ & $\begin{array}{c}\text { No. of } \\
\text { participants }\end{array}$ & Statistical method & Effect size \\
\hline $\begin{array}{l}1 \text { Microbiological efficacy - } \\
\text { pathogen eradication }\end{array}$ & 1 & 23 & Risk Ratio (M-H, Fixed, 95\% CI) & $1.04[0.76,1.42]$ \\
\hline $\begin{array}{l}2 \text { Clinical efficacy (cure or } \\
\text { improvement) at the end of } \\
\text { treatment }\end{array}$ & 1 & 23 & Risk Ratio (M-H, Random, 95\% CI) & $1.06[0.85,1.32]$ \\
\hline 3 Adverse effects of treatment & 1 & & Risk Ratio (M-H, Random, 95\% CI) & Subtotals only \\
\hline 3.1 Any adverse effects & 1 & 46 & Risk Ratio (M-H, Random, 95\% CI) & $0.73[0.31,1.71]$ \\
\hline
\end{tabular}


3.2 Gastrointestinal adverse effects

3.3 Dermal toxicity

3.4 Nervous (sic)

3.5 Special senses toxicity

3.6 Respiratory toxicity

1
1
1
1
1

46

Risk Ratio (M-H, Random, 95\% CI)

$0.47[0.14,1.59]$

Risk Ratio (M-H, Random, 95\% CI)

$3.26[0.14,76.10]$

$5.43[0.28,107.33]$

$0.16[0.01,2.85]$

$0.36[0.02,8.46]$

\section{Comparison 11. Fluoroquinolone versus other antibacterial agent: lomefloxacin versus co-trimoxazole}

\begin{tabular}{|c|c|c|c|c|}
\hline Outcome or subgroup title & $\begin{array}{l}\text { No. of } \\
\text { studies }\end{array}$ & $\begin{array}{c}\text { No. of } \\
\text { participants }\end{array}$ & Statistical method & Effect size \\
\hline 1 Microbiological efficacy & 1 & & Risk Ratio (M-H, Fixed, 95\% CI) & Subtotals only \\
\hline $\begin{array}{l}\text { 1.1 Microbiological success } \\
\text { (pathogen eradication) at the } \\
\text { end of treatment }\end{array}$ & 1 & 26 & Risk Ratio (M-H, Fixed, 95\% CI) & $1.09[0.82,1.44]$ \\
\hline $\begin{array}{l}1.2 \text { Microbiological success } \\
\text { (pathogen eradication) at } \\
\text { follow-up ( } 4 \text { months) }\end{array}$ & 1 & 26 & Risk Ratio (M-H, Fixed, 95\% CI) & $1.09[0.82,1.44]$ \\
\hline 2 Clinical efficacy & 1 & & Risk Ratio (M-H, Random, 95\% CI) & Subtotals only \\
\hline $\begin{array}{l}2.1 \text { Clinical efficacy (cure or } \\
\text { improvement) at the end of } \\
\text { treatment }\end{array}$ & 1 & 26 & Risk Ratio (M-H, Random, 95\% CI) & $1.0[0.87,1.15]$ \\
\hline $\begin{array}{l}2.2 \text { Clinical efficacy (cure or } \\
\text { improvement) at follow-up ( } 4 \\
\text { months) }\end{array}$ & 1 & 26 & Risk Ratio (M-H, Random, 95\% CI) & $1.0[0.87,1.15]$ \\
\hline 3 Adverse effects of treatment & 1 & & Risk Ratio (M-H, Random, 95\% CI) & Subtotals only \\
\hline 3.1 Any adverse effects & 1 & 28 & Risk Ratio (M-H, Random, 95\% CI) & $0.43[0.04,4.25]$ \\
\hline $\begin{array}{l}3.2 \text { Gastrointestinal adverse } \\
\text { effects }\end{array}$ & 1 & 28 & Risk Ratio (M-H, Random, 95\% CI) & $0.43[0.04,4.25]$ \\
\hline
\end{tabular}

Comparison 12. Fluoroquinolone versus other antibacterial agent: ciprofloxacin versus azithromycin in chlamydial prostatitis

\begin{tabular}{|c|c|c|c|c|}
\hline Outcome or subgroup title & $\begin{array}{l}\text { No. of } \\
\text { studies }\end{array}$ & $\begin{array}{c}\text { No. of } \\
\text { participants }\end{array}$ & Statistical method & Effect size \\
\hline $\begin{array}{l}1 \text { Microbiological efficacy } \\
\text { (pathogen eradication) at the } \\
\text { end of treatment }\end{array}$ & 1 & 89 & Risk Ratio (M-H, Fixed, 95\% CI) & $0.48[0.32,0.72]$ \\
\hline $\begin{array}{l}2 \text { Clinical efficacy (cure or } \\
\text { improvement) at the end of } \\
\text { treatment }\end{array}$ & 1 & 89 & Risk Ratio (M-H, Random, 95\% CI) & $0.64[0.46,0.90]$ \\
\hline 3 Adverse effects of treatment & 1 & & Risk Ratio (M-H, Random, 95\% CI) & Subtotals only \\
\hline 3.1 Any adverse effects & 1 & 89 & Risk Ratio (M-H, Random, 95\% CI) & $0.34[0.01,8.15]$ \\
\hline $\begin{array}{l}3.2 \text { Gastrointestinal adverse } \\
\text { effects }\end{array}$ & 1 & 89 & Risk Ratio (M-H, Random, 95\% CI) & $0.34[0.01,8.15]$ \\
\hline
\end{tabular}

Antimicrobial therapy for chronic bacterial prostatitis (Review) 
Comparison 13. Non-fluoroquinolone antibacterial agents: minocycline versus cephalexin

\begin{tabular}{lcccc} 
Outcome or subgroup title & $\begin{array}{c}\text { No. of } \\
\text { studies }\end{array}$ & $\begin{array}{c}\text { No. of } \\
\text { participants }\end{array}$ & Statistical method & Effect size \\
\hline $\begin{array}{l}\text { Microbiological efficacy } \\
\text { (pathogen eradication and } \\
\text { eradication plus superinfection) } \\
\text { at the end of treatment }\end{array}$ & 1 & 27 & Risk Ratio (M-H, Fixed, 95\% CI) & $1.7[0.54,5.34]$ \\
$\begin{array}{l}2 \text { Clinical efficacy (cure or } \\
\text { improvement) at the end of } \\
\text { treatment }\end{array}$ & 1 & 27 & Risk Ratio (M-H, Random, 95\% CI) & $2.04[0.83,4.99]$ \\
3 Microbiological recurrence & 1 & 20 & Risk Ratio (M-H, Random, 95\% CI) & $0.98[0.37,2.59]$ \\
\hline
\end{tabular}

Comparison 14. Non-fluoroquinolone antibacterial agents: azithromycin versus clarithromycin in chlamydial prostatitis

\begin{tabular}{|c|c|c|c|c|}
\hline Outcome or subgroup title & $\begin{array}{l}\text { No. of } \\
\text { studies }\end{array}$ & $\begin{array}{c}\text { No. of } \\
\text { participants }\end{array}$ & Statistical method & Effect size \\
\hline $\begin{array}{l}\text { 1 Microbiological efficacy } \\
\text { (pathogen eradication) at the } \\
\text { end of treatment }\end{array}$ & 1 & 91 & Risk Ratio (M-H, Fixed, 95\% CI) & $1.01[0.82,1.23]$ \\
\hline $\begin{array}{l}2 \text { Clinical efficacy (cure) at the end } \\
\text { of treatment }\end{array}$ & 1 & 91 & Risk Ratio (M-H, Random, 95\% CI) & $0.98[0.75,1.28]$ \\
\hline 3 Adverse effects of treatment & 1 & & Risk Ratio (M-H, Random, 95\% CI) & Subtotals only \\
\hline 3.1 Any adverse effects & 1 & 91 & Risk Ratio (M-H, Random, 95\% CI) & $1.96[0.18,20.83]$ \\
\hline $\begin{array}{l}\text { 3.2 Gastrointestinal adverse } \\
\text { effects }\end{array}$ & 1 & 91 & Risk Ratio (M-H, Random, 95\% CI) & $1.96[0.18,20.83]$ \\
\hline $\begin{array}{l}\text { 3.3 Hepatic adverse effects } \\
\text { (increased transaminases) }\end{array}$ & 1 & 91 & Risk Ratio (M-H, Random, 95\% CI) & $1.96[0.18,20.83]$ \\
\hline
\end{tabular}


Comparison 15. Non-fluoroquinolone antibacterial agents: azithromycin versus doxycycline in chlamydial prostatitis

\begin{tabular}{|c|c|c|c|c|}
\hline Outcome or subgroup title & $\begin{array}{l}\text { No. of } \\
\text { studies }\end{array}$ & $\begin{array}{c}\text { No. of } \\
\text { participants }\end{array}$ & Statistical method & Effect size \\
\hline $\begin{array}{l}1 \text { Microbiological efficacy } \\
\text { (pathogen eradication) at the } \\
\text { end of treatment }\end{array}$ & 1 & 125 & Risk Ratio (M-H, Fixed, 95\% CI) & $1.03[0.85,1.26]$ \\
\hline 2 Clinical efficacy & 1 & & Risk Ratio (M-H, Random, 95\% CI) & Subtotals only \\
\hline $\begin{array}{l}\text { 2.1 Clinical efficacy - presence } \\
\text { of inflammatory findings } \\
\text { (number of participants with } \\
\text { white blood cell counts in } \\
\text { EPS/VB3 < } 10 \text { per high power } \\
\text { field) at the end of therapy }\end{array}$ & 1 & 125 & Risk Ratio (M-H, Random, 95\% CI) & $1.08[0.66,1.78]$ \\
\hline $\begin{array}{l}2.2 \text { Clinical efficacy (cure or } \\
\text { improvement) at the end of } \\
\text { therapy }\end{array}$ & 1 & 125 & Risk Ratio (M-H, Random, 95\% CI) & $0.95[0.76,1.19]$ \\
\hline 3 Adverse effects of treatment & 1 & & Risk Ratio (M-H, Random, 95\% CI) & Subtotals only \\
\hline 3.1 Any adverse effects & 1 & 125 & Risk Ratio (M-H, Random, 95\% CI) & $0.21[0.04,1.04]$ \\
\hline $\begin{array}{l}\text { 3.2 Gastrointestinal adverse } \\
\text { effects }\end{array}$ & 1 & 125 & Risk Ratio (M-H, Random, 95\% CI) & $0.21[0.04,1.04]$ \\
\hline $\begin{array}{l}3.3 \text { Hepatic adverse effects } \\
\text { (increased transaminases) }\end{array}$ & 1 & 125 & Risk Ratio (M-H, Random, 95\% CI) & $2.65[0.13,54.00]$ \\
\hline
\end{tabular}

Comparison 16. Non-fluoroquinolone antibacterial agents: azithromycin versus doxycycline in ureaplasmal prostatitis

\begin{tabular}{|c|c|c|c|c|}
\hline Outcome or subgroup title & $\begin{array}{l}\text { No. of } \\
\text { studies }\end{array}$ & $\begin{array}{c}\text { No. of } \\
\text { participants }\end{array}$ & Statistical method & Effect size \\
\hline $\begin{array}{l}1 \text { Microbiological efficacy } \\
\text { (pathogen eradication) at the } \\
\text { end of treatment }\end{array}$ & 1 & 63 & Risk Ratio (M-H, Fixed, 95\% CI) & $1.05[0.80,1.39]$ \\
\hline $\begin{array}{l}2 \text { Clinical efficacy (cure) at the end } \\
\text { of treatment }\end{array}$ & 1 & 63 & Risk Ratio (M-H, Random, 95\% CI) & $1.01[0.72,1.42]$ \\
\hline 3 Adverse effects of treatment & 1 & & Risk Ratio (M-H, Random, 95\% CI) & Subtotals only \\
\hline 3.1 Any adverse effects & 1 & 63 & Risk Ratio (M-H, Random, 95\% CI) & $0.09[0.01,1.53]$ \\
\hline $\begin{array}{l}3.2 \text { Gastrointestinal adverse } \\
\text { effects }\end{array}$ & 1 & 63 & Risk Ratio (M-H, Random, 95\% CI) & $0.09[0.01,1.53]$ \\
\hline
\end{tabular}


Comparison 17. Different dosing regimens: azithromycin $4.5 \mathrm{~g}$ versus $6.0 \mathrm{~g}$ total doses in chlamydial prostatitis

\begin{tabular}{|c|c|c|c|c|}
\hline Outcome or subgroup title & $\begin{array}{l}\text { No. of } \\
\text { studies }\end{array}$ & $\begin{array}{c}\text { No. of } \\
\text { participants }\end{array}$ & Statistical method & Effect size \\
\hline $\begin{array}{l}\text { 1 Microbiological efficacy } \\
\text { (pathogen eradication) at the } \\
\text { end of treatment }\end{array}$ & 1 & 89 & Risk Ratio (M-H, Fixed, 95\% CI) & $0.99[0.81,1.21]$ \\
\hline $\begin{array}{l}2 \text { Clinical efficacy (cure) at the end } \\
\text { of therapy }\end{array}$ & 1 & 89 & Risk Ratio (M-H, Random, 95\% CI) & $0.96[0.74,1.26]$ \\
\hline 3 Adverse effects of treatment & 1 & & Risk Ratio (M-H, Random, 95\% CI) & Subtotals only \\
\hline 3.1 Any adverse effects & 1 & 89 & Risk Ratio (M-H, Random, 95\% CI) & $0.19[0.01,3.79]$ \\
\hline $\begin{array}{l}3.2 \text { Hepatic adverse effects } \\
\text { (increased transaminases) }\end{array}$ & 1 & 89 & Risk Ratio (M-H, Random, 95\% CI) & $0.19[0.01,3.79]$ \\
\hline
\end{tabular}

Comparison 18. Different therapy duration: co-trimoxazole $480 \mathrm{mg}$ twice daily for 12 weeks versus 10 days

\begin{tabular}{|c|c|c|c|c|}
\hline Outcome or subgroup title & $\begin{array}{l}\text { No. of } \\
\text { studies }\end{array}$ & $\begin{array}{c}\text { No. of } \\
\text { participants }\end{array}$ & Statistical method & Effect size \\
\hline $\begin{array}{l}1 \text { Microbiological efficacy } \\
\text { (pathogen eradication) at the } \\
\text { end of treatment }\end{array}$ & 1 & 30 & Risk Ratio (M-H, Fixed, 95\% CI) & $3.0[1.01,8.95]$ \\
\hline 2 Adverse effects of treatment & 1 & & Risk Ratio (M-H, Random, 95\% CI) & Subtotals only \\
\hline 2.1 Any adverse effects & 1 & 33 & Risk Ratio (M-H, Random, 95\% CI) & $0.53[0.05,5.31]$ \\
\hline $\begin{array}{l}2.2 \text { Gastrointestinal/hepatic } \\
\text { adverse effects }\end{array}$ & 1 & 33 & Risk Ratio (M-H, Random, 95\% CI) & $0.21[0.01,4.10]$ \\
\hline 2.3 Drop in leukocyte counts & 1 & 33 & Risk Ratio (M-H, Random, 95\% CI) & $3.18[0.14,72.75]$ \\
\hline
\end{tabular}

Comparison 19. Fluoroquinolone combined with phosphodiesterase-5 inhibitor versus fluoroquinolone: levofloxacin plus vardenafil $10 \mathrm{mg} /$ day versus levofloxacin

\begin{tabular}{|c|c|c|c|c|}
\hline Outcome or subgroup title & $\begin{array}{l}\text { No. of } \\
\text { studies }\end{array}$ & $\begin{array}{c}\text { No. of } \\
\text { participants }\end{array}$ & Statistical method & Effect size \\
\hline $\begin{array}{l}1 \text { Microbiological efficacy } \\
\text { (pathogen eradication) at the } \\
\text { end of treatment }\end{array}$ & 1 & 66 & Risk Ratio (M-H, Fixed, 95\% CI) & $1.04[0.90,1.19]$ \\
\hline $\begin{array}{l}2 \text { Clinical efficacy - NIH-CPSI } \\
\text { score at the end of treatment }\end{array}$ & 1 & & Std. Mean Difference (IV, Random, 95\% CI) & Subtotals only \\
\hline 2.1 NIH-CPSI pain score & 1 & 66 & Std. Mean Difference (IV, Random, 95\% CI) & $-0.13[-0.62,0.35]$ \\
\hline $\begin{array}{l}2.2 \mathrm{NIH}-\mathrm{CPSI} \text { voiding } \\
\text { symptom score }\end{array}$ & 1 & 66 & Std. Mean Difference (IV, Random, 95\% CI) & $-0.30[-0.78,0.19]$ \\
\hline $\begin{array}{l}2.3 \mathrm{NIH}-\mathrm{CPSI} \text { quality of life } \\
\text { impact score }\end{array}$ & 1 & 66 & Std. Mean Difference (IV, Random, 95\% CI) & $-0.24[-0.72,0.25]$ \\
\hline
\end{tabular}

Antimicrobial therapy for chronic bacterial prostatitis (Review) 
3 Clinical efficacy - number of

Comparison 20. Fluoroquinolone combined with phosphodiesterase-5 inhibitor versus fluoroquinolone: levofloxacin plus vardenafil $10 \mathrm{mg}$ on-demand versus levofloxacin

\begin{tabular}{|c|c|c|c|c|}
\hline Outcome or subgroup title & $\begin{array}{l}\text { No. of } \\
\text { studies }\end{array}$ & $\begin{array}{c}\text { No. of } \\
\text { participants }\end{array}$ & Statistical method & Effect size \\
\hline $\begin{array}{l}1 \text { Microbiological efficacy } \\
\text { (pathogen eradication) at the } \\
\text { end of treatment }\end{array}$ & 1 & 69 & Risk Ratio (M-H, Fixed, 95\% CI) & $1.01[0.88,1.17]$ \\
\hline $\begin{array}{l}2 \text { Clinical efficacy - NIH-CPSI } \\
\text { score at the end of treatment }\end{array}$ & 1 & & Std. Mean Difference (IV, Random, 95\% CI) & Subtotals only \\
\hline 2.1 NIH-CPSI pain score & 1 & 69 & Std. Mean Difference (IV, Random, 95\% CI) & $-0.06[-0.53,0.42]$ \\
\hline $\begin{array}{l}2.2 \text { NIH-CPSI voiding } \\
\text { symptom score }\end{array}$ & 1 & 69 & Std. Mean Difference (IV, Random, 95\% CI) & $0.27[-0.20,0.75]$ \\
\hline $\begin{array}{l}2.3 \text { NIH-CPSI quality of life } \\
\text { impact score }\end{array}$ & 1 & 69 & Std. Mean Difference (IV, Random, 95\% CI) & $0.52[0.04,1.01]$ \\
\hline $\begin{array}{l}3 \text { Clinical efficacy - number of } \\
\text { participants with leukocytosis } \\
\text { in post-massage urine } \\
\text { specimens at the end of } \\
\text { treatment }\end{array}$ & 1 & 69 & Risk Ratio (M-H, Random, 95\% CI) & $0.74[0.28,1.98]$ \\
\hline $\begin{array}{l}4 \text { Clinical efficacy - urine peak flow } \\
\text { rate at the end of treatment } \\
(\mathrm{mL} / \mathrm{s})\end{array}$ & 1 & 69 & Std. Mean Difference (IV, Random, 95\% CI) & $0.10[-0.37,0.57]$ \\
\hline
\end{tabular}

Comparison 21. Fluoroquinolone combined with phosphodiesterase-5 inhibitor: levofloxacin plus vardenafil 10 $\mathrm{mg} /$ day versus levofloxacin plus vardenafil $10 \mathrm{mg}$ on-demand

\begin{tabular}{lcccc} 
Outcome or subgroup title & $\begin{array}{c}\text { No. of } \\
\text { studies }\end{array}$ & $\begin{array}{c}\text { No. of } \\
\text { participants }\end{array}$ & Statistical method & Effect size \\
\hline $\begin{array}{l}1 \text { Microbiological efficacy } \\
\text { (pathogen eradication) at the }\end{array}$ & 1 & 71 & Risk Ratio (M-H, Fixed, 95\% CI) & $1.02[0.90,1.16]$ \\
$\begin{array}{l}\text { end of treatment } \\
2 \text { Clinical efficacy - NIH-CPSI }\end{array}$ & 1 & Std. Mean Difference (IV, Random, 95\% CI) & Subtotals only \\
$\begin{array}{l}\text { score at the end of treatment } \\
2.1 \text { NIH-CPSI pain score }\end{array}$ & 1 & 71 & Std. Mean Difference (IV, Random, 95\% CI) & $-0.09[-0.55,0.38]$ \\
\hline $\begin{array}{l}\text { Antimicrobial therapy for chronic bacterial prostatitis (Review) } \\
\text { Copyright } \odot \mathbf{2 0 1 3} \text { The Cochrane Collaboration. Published by John Wiley \& Sons, Ltd. }\end{array}$ & $\mathbf{7 4}$
\end{tabular}


2.2 NIH-CPSI voiding symptom score

2.3 NIH-CPSI quality of life impact score

3 Clinical efficacy - number of participants with leukocytosis in post-massage urine specimens at the end of treatment

4 Clinical efficacy - urine peak flow rate at the end of treatment $(\mathrm{mL} / \mathrm{s})$

Comparison 22. Fluoroquinolone plus herbal extracts or supplements versus fluoroquinolone: prulifloxacin plus supplements versus prulifloxacin

\begin{tabular}{|c|c|c|c|c|}
\hline Outcome or subgroup title & $\begin{array}{l}\text { No. of } \\
\text { studies }\end{array}$ & $\begin{array}{c}\text { No. of } \\
\text { participants }\end{array}$ & Statistical method & Effect size \\
\hline $\begin{array}{l}1 \text { Clinical efficacy - NIH-CPSI } \\
\text { total score }\end{array}$ & 1 & & Std. Mean Difference (IV, Random, 95\% CI) & Subtotals only \\
\hline $\begin{array}{l}\text { 1.1 NIH-CPSI total score at } \\
\text { the end of treatment }\end{array}$ & 1 & 143 & Std. Mean Difference (IV, Random, 95\% CI) & $-2.56[-3.04,-2.08]$ \\
\hline $\begin{array}{l}1.2 \text { NIH-CPSI total score at } \\
\text { follow-up ( } 6 \text { months) }\end{array}$ & 1 & 143 & Std. Mean Difference (IV, Random, 95\% CI) & $-3.78[-4.36,-3.20]$ \\
\hline 2 Clinical efficacy - IPSS score & 1 & & Std. Mean Difference (IV, Random, 95\% CI) & Subtotals only \\
\hline $\begin{array}{l}2.1 \text { IPSS score at the end of } \\
\text { treatment }\end{array}$ & 1 & 143 & Std. Mean Difference (IV, Random, 95\% CI) & $-2.21[-2.66,-1.75]$ \\
\hline 2.2 IPSS score at follow-up & 1 & 143 & Std. Mean Difference (IV, Random, 95\% CI) & $-2.50[-2.98,-2.03]$ \\
\hline 3 Adverse effects of treatment & 1 & 143 & Risk Ratio (M-H, Random, 95\% CI) & $1.05[0.11,9.76]$ \\
\hline
\end{tabular}




\section{Analysis I.I. Comparison I Different fluoroquinolones: levofloxacin versus ciprofloxacin, Outcome I Microbiological efficacy - pathogen eradication (fixed-effect model).}

Review: Antimicrobial therapy for chronic bacterial prostatitis

Comparison: I Different fluoroquinolones: levofloxacin versus ciprofloxacin

Outcome: I Microbiological efficacy - pathogen eradication (fixed-effect model)

\begin{tabular}{|c|c|c|c|c|c|}
\hline \multirow[t]{2}{*}{ Study or subgroup } & Levofloxacin & Ciprofloxacin & Risk Ratio & Weight & Risk Ratio \\
\hline & $\mathrm{n} / \mathrm{N}$ & $\mathrm{n} / \mathrm{N}$ & M-H,Fixed,95\% Cl & & M-H,Fixed,95\% Cl \\
\hline Bundrick 2003 & $102 / 136$ & $96 / 125$ & & $44.9 \%$ & $0.98[0.85,1.12]$ \\
\hline Zhang 2012 & 179/209 & $120 / 199$ & & $55.1 \%$ & $1.42[1.25,1.61]$ \\
\hline
\end{tabular}

Total (95\% CI)

345

324

$100.0 \%$

$1.22[1.11,1.34]$

Total events: 28I (Levofloxacin), 216 (Ciprofloxacin)

Heterogeneity: Chi $^{2}=15.82, d f=|(P=0.00007) ;|^{2}=94 \%$

Test for overall effect: $Z=4.23(P=0.000024)$

Test for subgroup differences: Not applicable

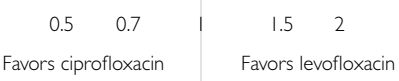

\section{Analysis I.2. Comparison I Different fluoroquinolones: levofloxacin versus ciprofloxacin, Outcome 2} Microbiological efficacy - pathogen eradication (random-effects model).

Review: Antimicrobial therapy for chronic bacterial prostatitis

Comparison: I Different fluoroquinolones: levofloxacin versus ciprofloxacin

Outcome: 2 Microbiological efficacy - pathogen eradication (random-effects model)

\begin{tabular}{|c|c|c|c|c|c|}
\hline Study or subgroup & Levofloxacin & Ciprofloxacin & $\begin{array}{r}\text { Risk Ratio } \\
\text { M- } \\
\text { H,Random,95\% } \\
\text { Cl }\end{array}$ & Weight & $\begin{array}{c}\text { Risk Ratio } \\
\text { M- } \\
\text { H,Random,95\% } \\
\text { Cl }\end{array}$ \\
\hline Bundrick 2003 & $102 / 136$ & $96 / 125$ & r & $49.7 \%$ & $0.98[0.85,1.12]$ \\
\hline Zhang 2012 & 179/209 & $120 / 199$ & $\rightarrow$ & $50.3 \%$ & $1.42[1.25,1.61]$ \\
\hline
\end{tabular}

Total (95\% CI)

345

324

$100.0 \%$

$1.18[0.81,1.71]$

Total events: 28I (Levofloxacin), 216 (Ciprofloxacin)

Heterogeneity: $\mathrm{Tau}^{2}=0.07 ; \mathrm{Chi}^{2}=15.82, \mathrm{df}=$ । $(\mathrm{P}=0.00007) ; \mathrm{I}^{2}=94 \%$

Test for overall effect: $Z=0.87(P=0.38)$

Test for subgroup differences: Not applicable

Favors levofloxacin

Copyright @ 2013 The Cochrane Collaboration. Published by John Wiley \& Sons, Ltd. 


\section{Analysis I.3. Comparison I Different fluoroquinolones: levofloxacin versus ciprofloxacin, Outcome 3}

\section{Clinical efficacy.}

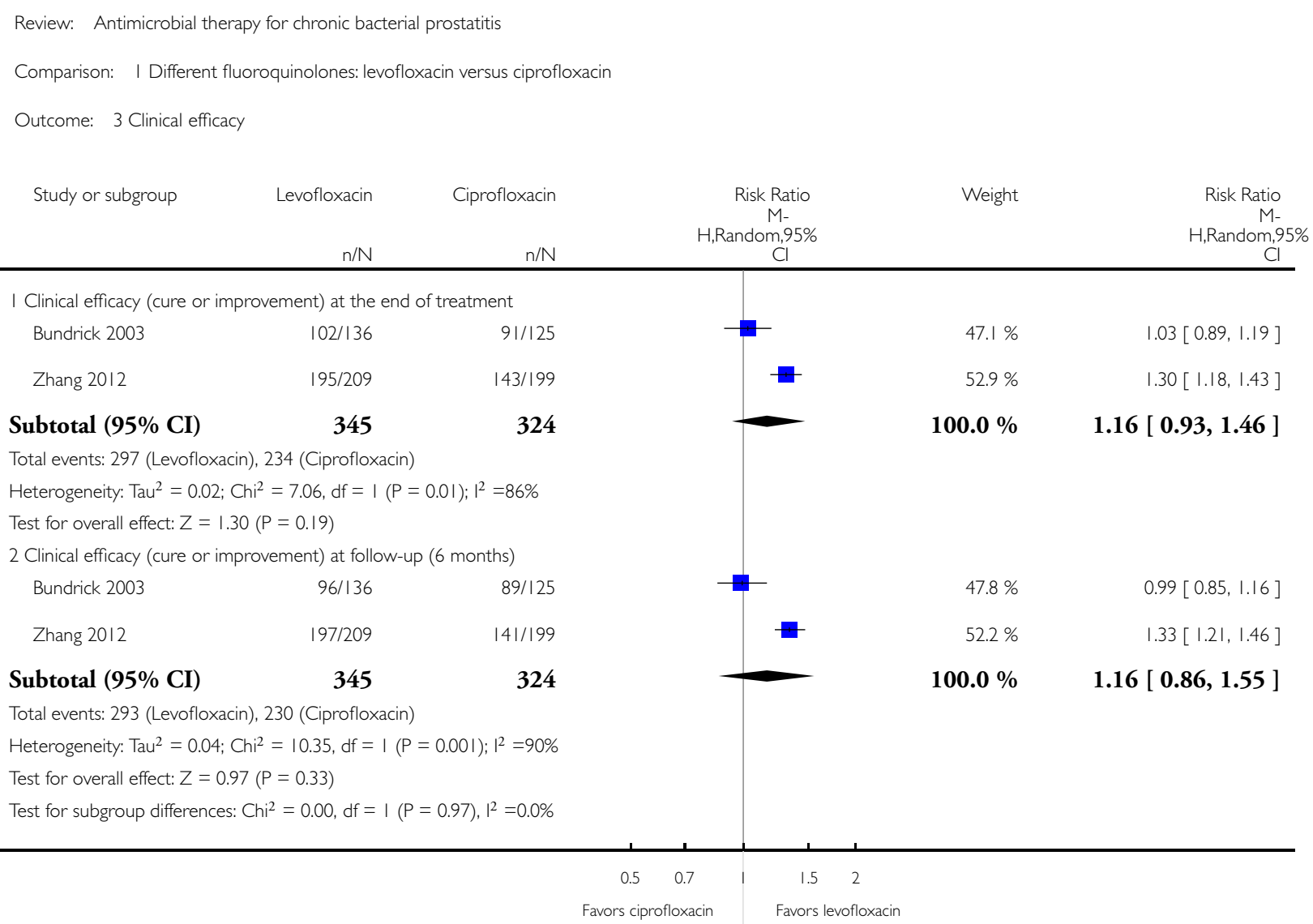




\section{Analysis I.4. Comparison I Different fluoroquinolones: levofloxacin versus ciprofloxacin, Outcome 4}

Adverse effects of treatment.

Review: Antimicrobial therapy for chronic bacterial prostatitis

Comparison: I Different fluoroquinolones: levofloxacin versus ciprofloxacin

Outcome: 4 Adverse effects of treatment

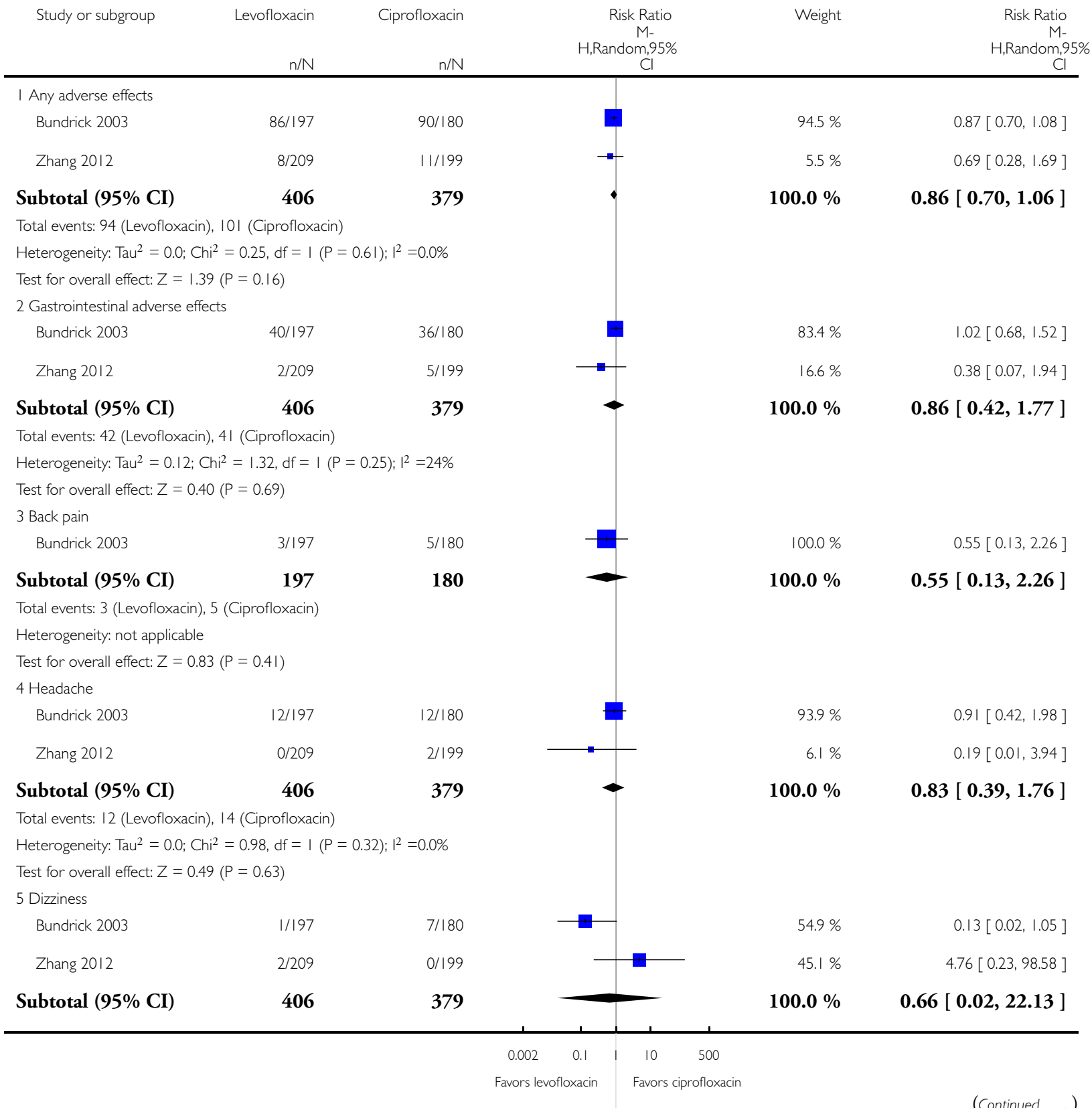




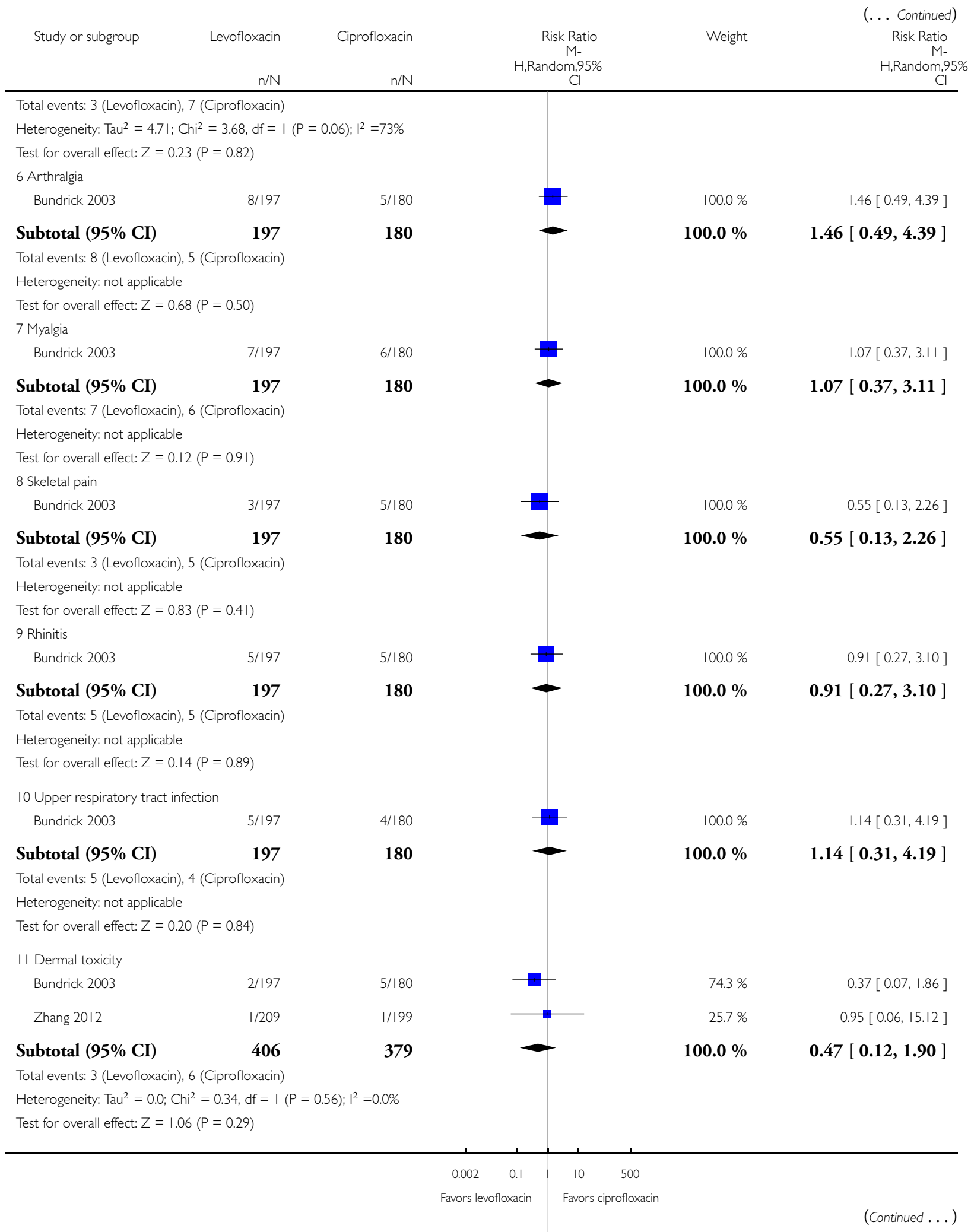

Antimicrobial therapy for chronic bacterial prostatitis (Review) 


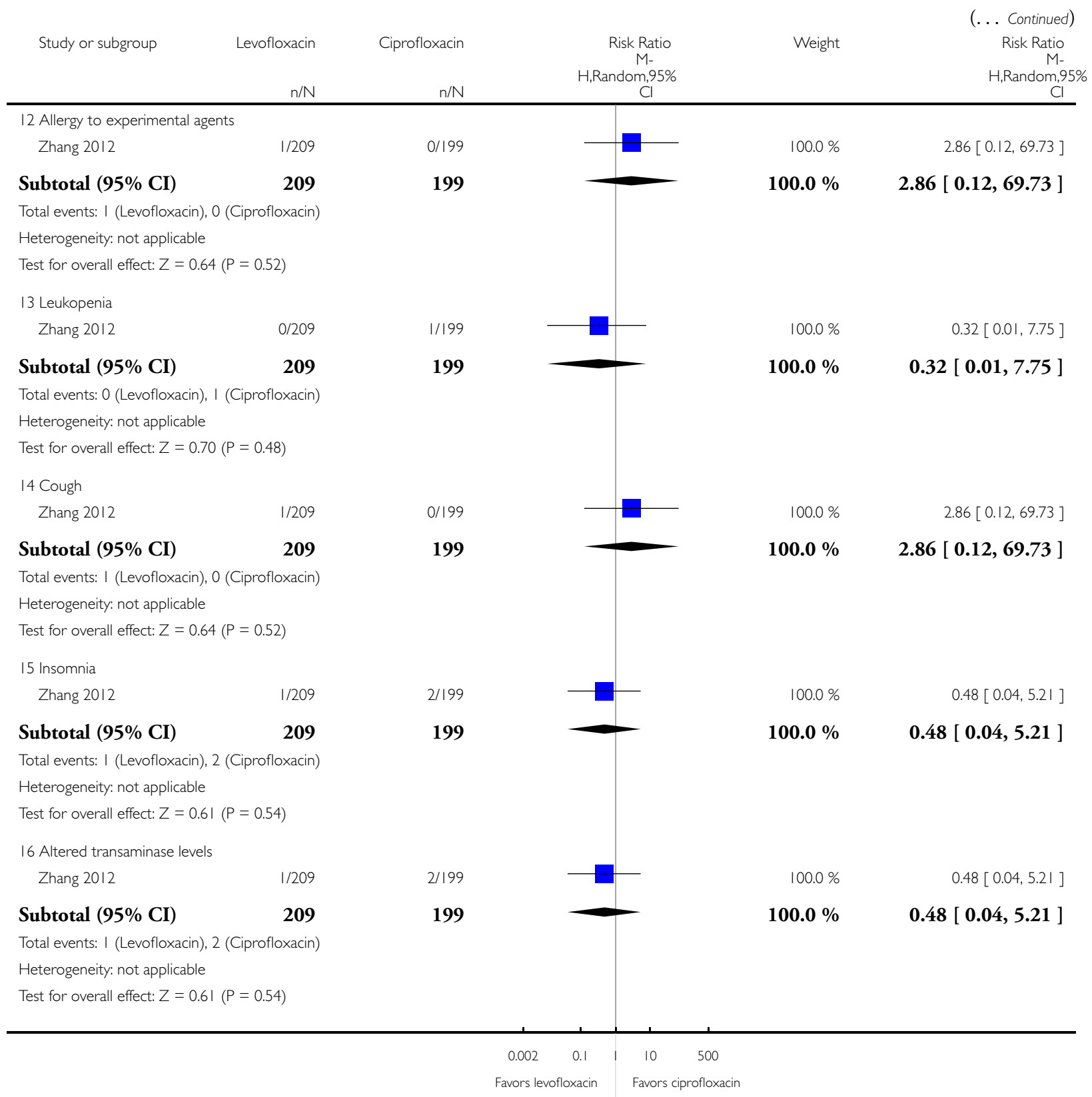


Analysis 2.I. Comparison 2 Different fluoroquinolones: prulifloxacin versus levofloxacin, Outcome I Microbiological efficacy - pathogen eradication.

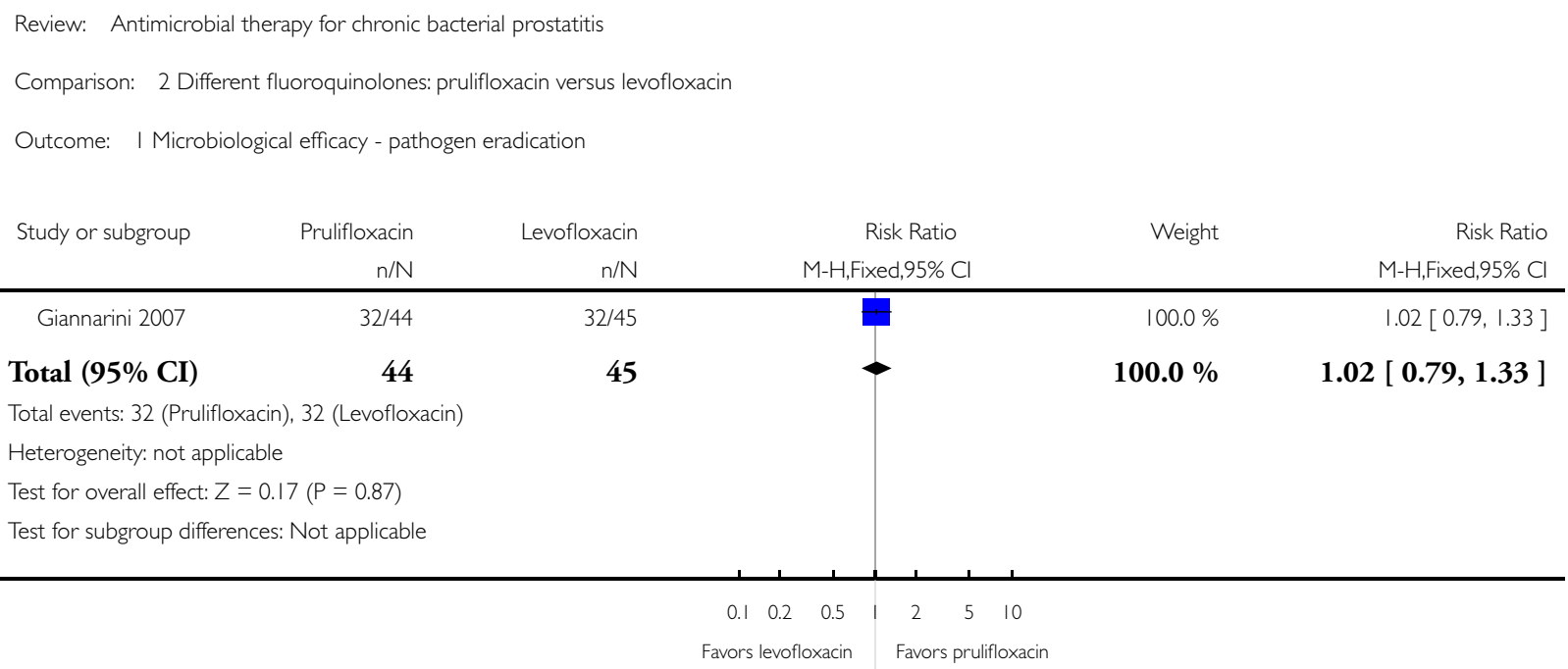

\section{Analysis 2.2. Comparison 2 Different fluoroquinolones: prulifloxacin versus levofloxacin, Outcome 2 Clinical efficacy - NIH-CPSI total score at the end of treatment.}

Review: Antimicrobial therapy for chronic bacterial prostatitis

Comparison: 2 Different fluoroquinolones: prulifloxacin versus levofloxacin

Outcome: 2 Clinical efficacy - NIH-CPSI total score at the end of treatment

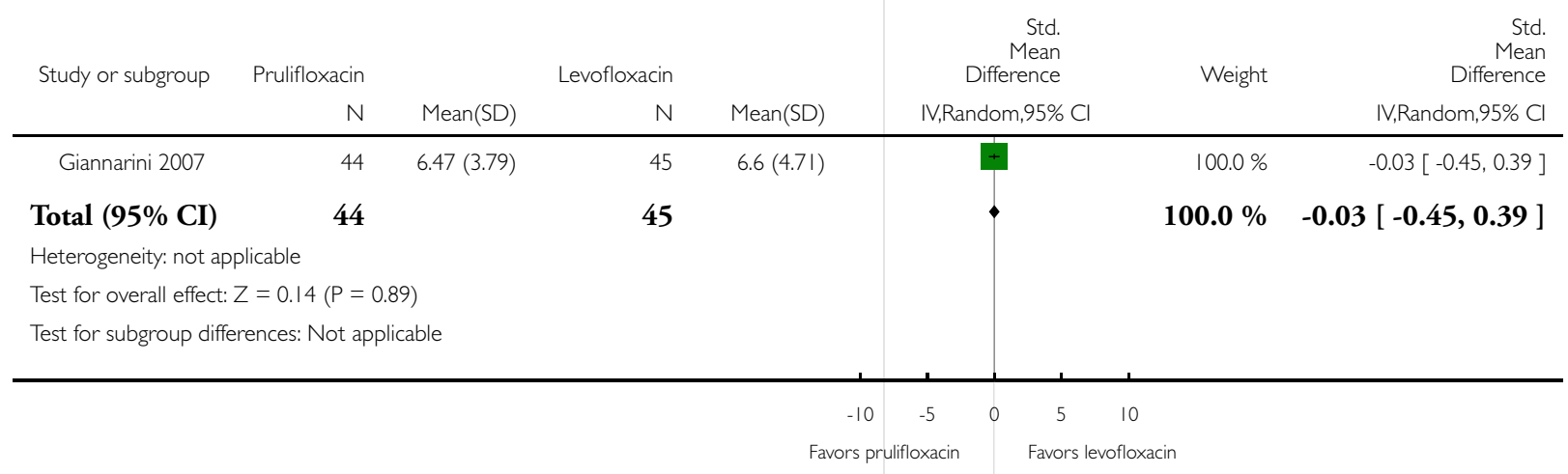


Analysis 2.3. Comparison 2 Different fluoroquinolones: prulifloxacin versus levofloxacin, Outcome 3 Adverse effects of treatment.

Review: Antimicrobial therapy for chronic bacterial prostatitis

Comparison: 2 Different fluoroquinolones: prulifloxacin versus levofloxacin

Outcome: 3 Adverse effects of treatment

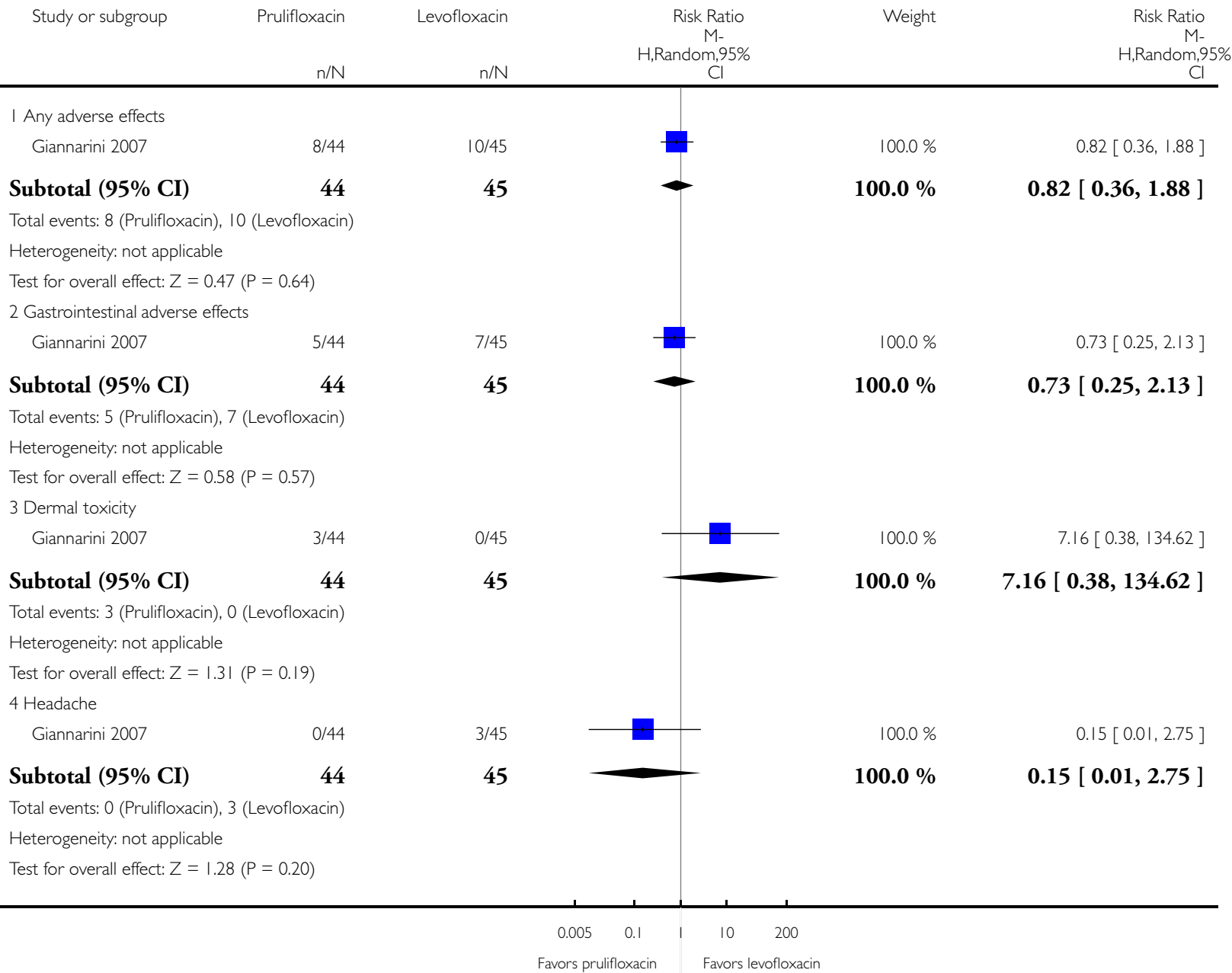


Analysis 3.I. Comparison 3 Different fluoroquinolones: lomefloxacin versus ofloxacin, Outcome I Microbiological efficacy - pathogen eradication at follow-up (6 months).

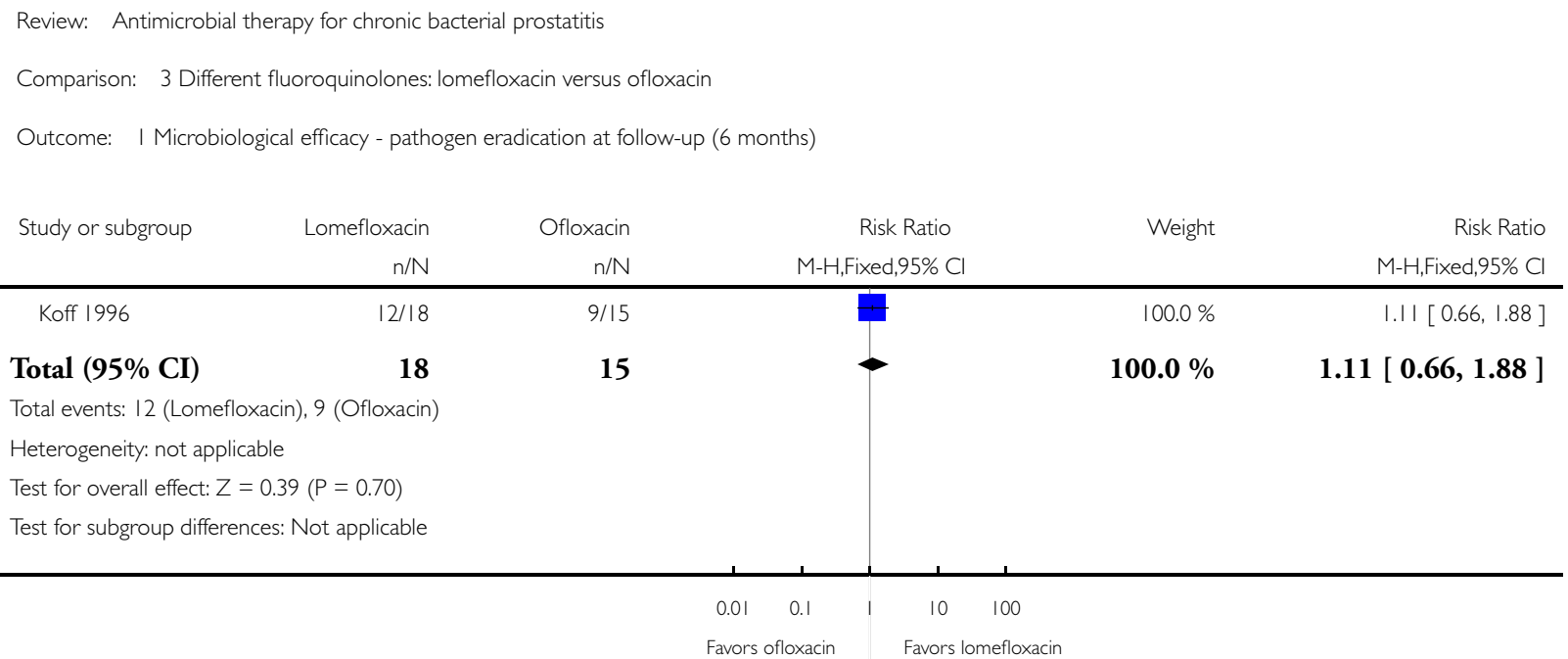




\section{Analysis 3.2. Comparison 3 Different fluoroquinolones: lomefloxacin versus ofloxacin, Outcome 2 Adverse effects of treatment.}

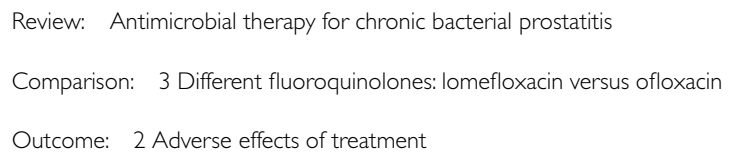

Total events: 4 (Lomefloxacin), 8 (Ofloxacin)

Heterogeneity: not applicable

Test for overall effect: $Z=1.74(P=0.082)$

2 Gastrointestinal adverse effects

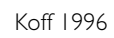

18

Subtotal (95\% CI)

Total events: 4 (Lomefloxacin), 6 (Ofloxacin)

Heterogeneity: not applicable

Test for overall effect: $Z=1.08(P=0.28)$

3 Headache

$$
\text { Koff } 1996
$$

Subtotal (95\% CI)

Total events: 0 (Lomefloxacin), I (Ofloxacin)

Heterogeneity: not applicable

Test for overall effect: $Z=0.80(P=0.43)$

4 Dizziness

$$
\text { Koff } 1996
$$

Subtotal (95\% CI)

Total events: 0 (Lomefloxacin), I (Ofloxacin)

Heterogeneity: not applicable

Test for overall effect: $Z=0.80(P=0.43)$

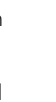

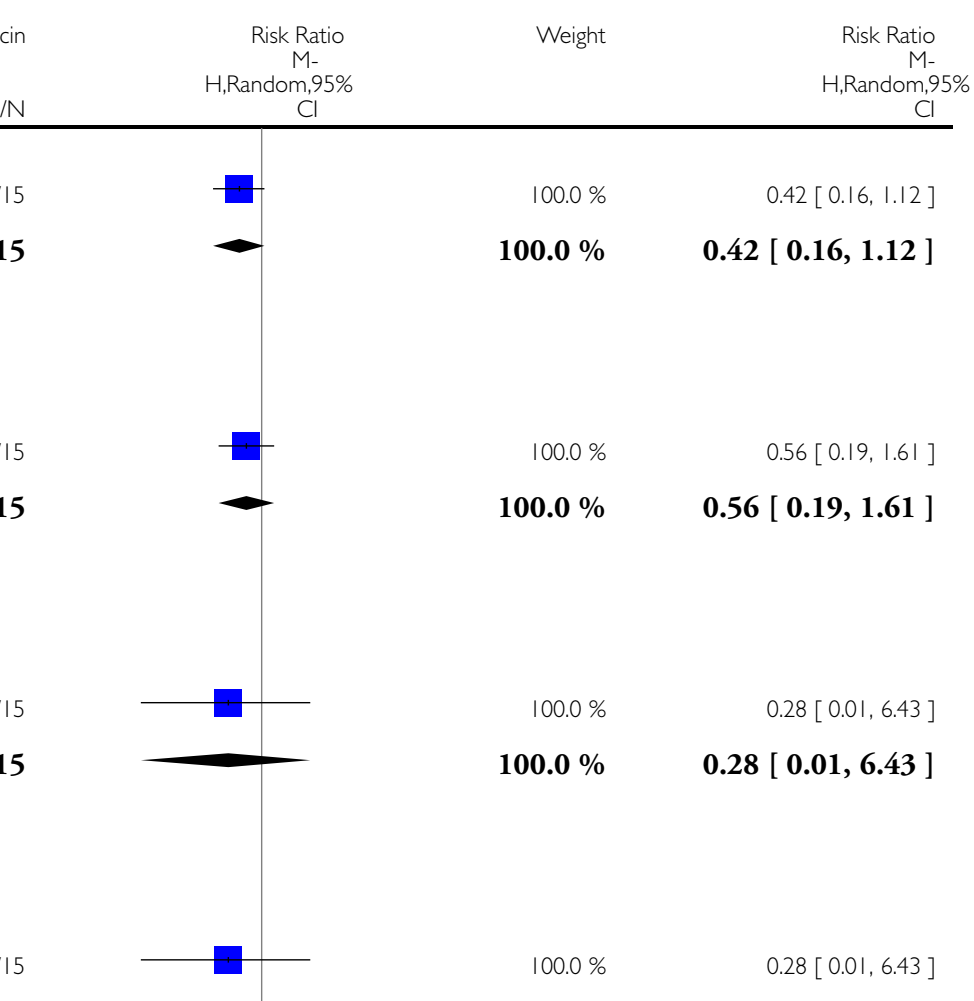

15

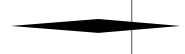

$100.0 \%$

0.28 [ $0.01,6.43$ ] 
Analysis 4.I. Comparison 4 Different fluoroquinolones: lomefloxacin versus ciprofloxacin, Outcome I Microbiological efficacy (intention-to-treat analysis).

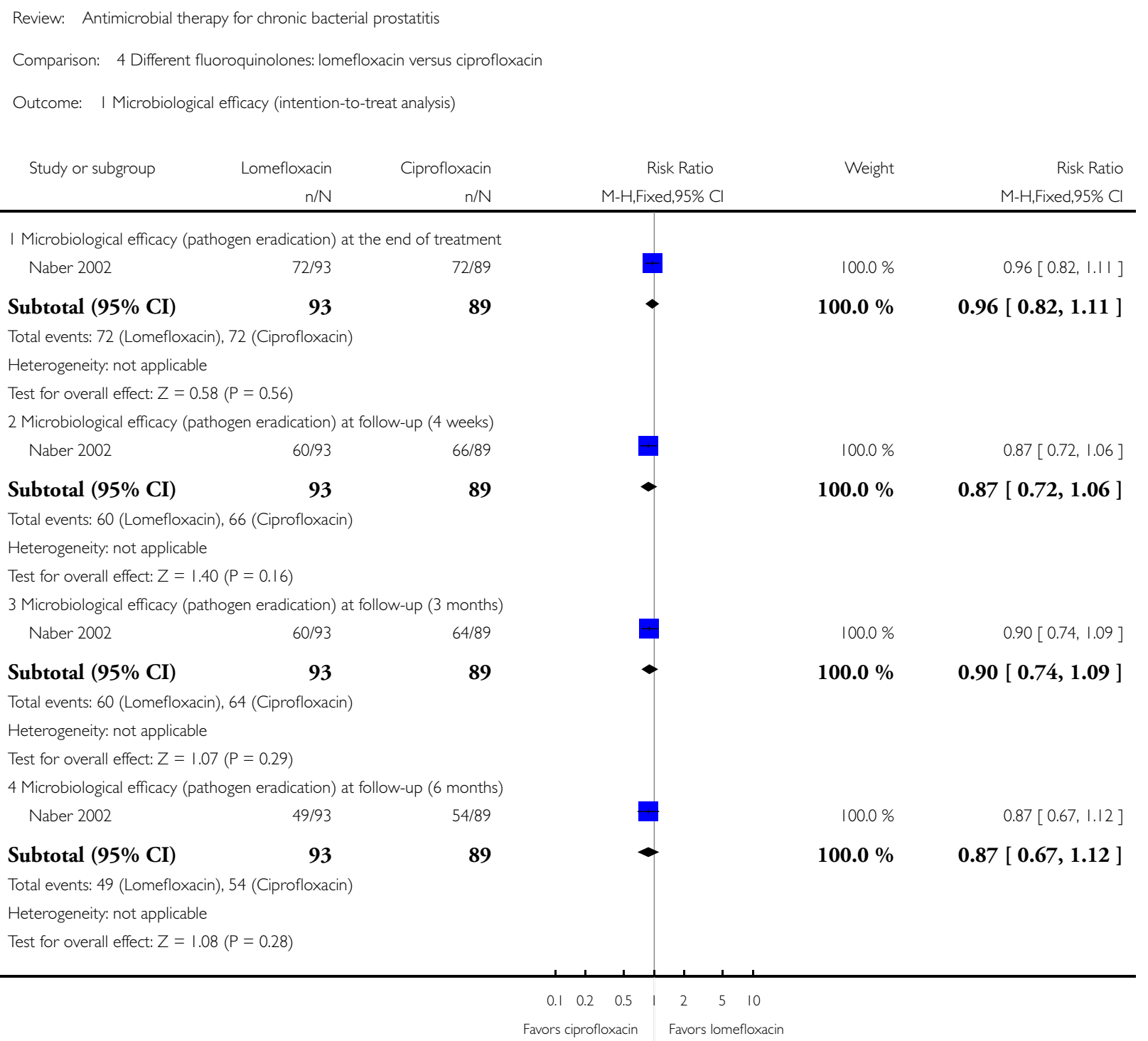




\section{Analysis 4.2. Comparison 4 Different fluoroquinolones: lomefloxacin versus ciprofloxacin, Outcome 2 Microbiological efficacy (per-protocol analysis).}

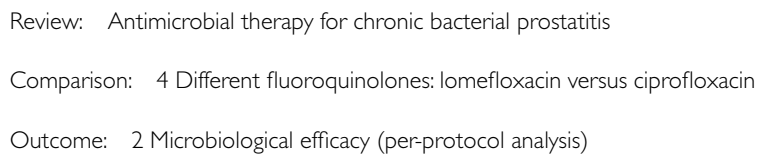

41

Total events: 43 (Lomefloxacin), 39 (Ciprofloxacin)

Heterogeneity: not applicable

Test for overall effect: $Z=0.33(P=0.74)$

2 Microbiological efficacy (pathogen eradication and eradication plus superinfection) at follow-up (4 weeks)

$$
\text { Naber } 2002 \quad 41 / 42 \quad 40 / 4 \mid
$$

Subtotal $(95 \% \mathrm{CI})$

42

\section{1}

Total events: 4 I (Lomefloxacin), 40 (Ciprofloxacin)

Heterogeneity: not applicable

Test for overall effect: $Z=0.02(P=0.99)$

3 Microbiological efficacy (pathogen eradication and eradication plus superinfection) at follow-up ( 3 months)

$$
\begin{array}{lll}
\text { Naber } 2002 & 37 / 38 & 37 / 39
\end{array}
$$

Subtotal (95\% CI)

38

39

Total events: 37 (Lomefloxacin), 37 (Ciprofloxacin)

Heterogeneity: not applicable

Test for overall effect: $Z=0.57(P=0.57)$

4 Microbiological efficacy (pathogen eradication and eradication plus superinfection) at follow-up (6 months)

$$
\text { Naber } 2002 \quad 31 / 33
$$

Subtotal (95\% CI)

33

Total events: 29 (Lomefloxacin), 31 (Ciprofloxacin)

Heterogeneity: not applicable

Test for overall effect: $Z=0.85(P=0.39)$
33

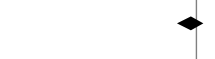

$100.0 \%$

0.98 [ $0.89,1.09$ ]

$100.0 \%$

$1.00[0.94,1.07]$

$100.0 \%$

$1.00[0.94,1.07$ ]

$100.0 \%$

$1.03[0.94,1.12]$

$100.0 \%$

1.03 [ $0.94,1.12$ ]

$100.0 \%$

$0.94[0.80,1.09]$

$100.0 \%$ 


\section{Analysis 4.3. Comparison 4 Different fluoroquinolones: lomefloxacin versus ciprofloxacin, Outcome 3} Clinical efficacy (intention-to-treat analysis).

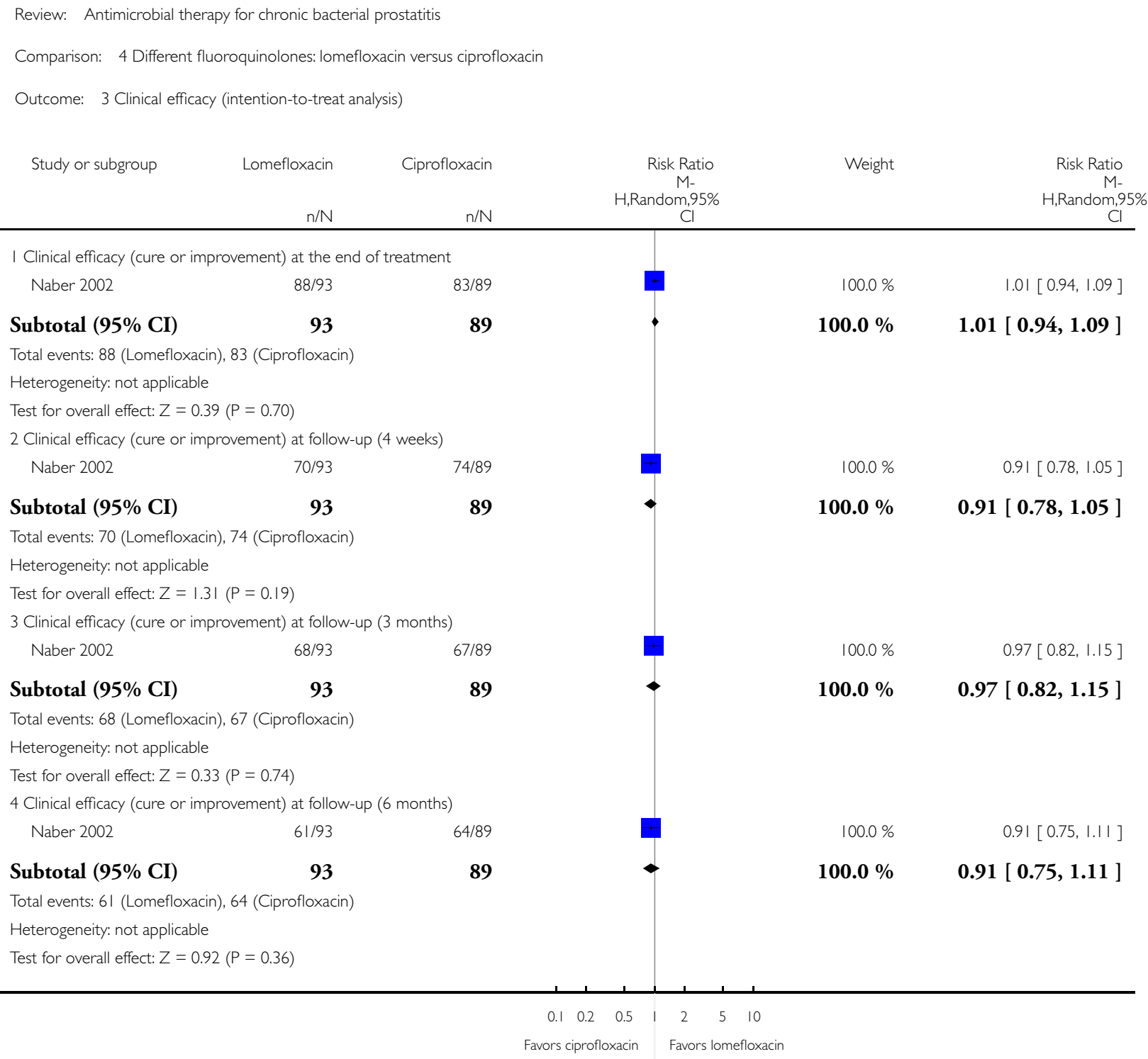

Total events: 61 (Lomefloxacin), 64 (Ciprofloxacin)

Heterogeneity: not applicable

Test for overall effect: $Z=0.92(P=0.36)$ 


\section{Analysis 4.4. Comparison 4 Different fluoroquinolones: lomefloxacin versus ciprofloxacin, Outcome 4} Clinical efficacy (per-protocol analysis).

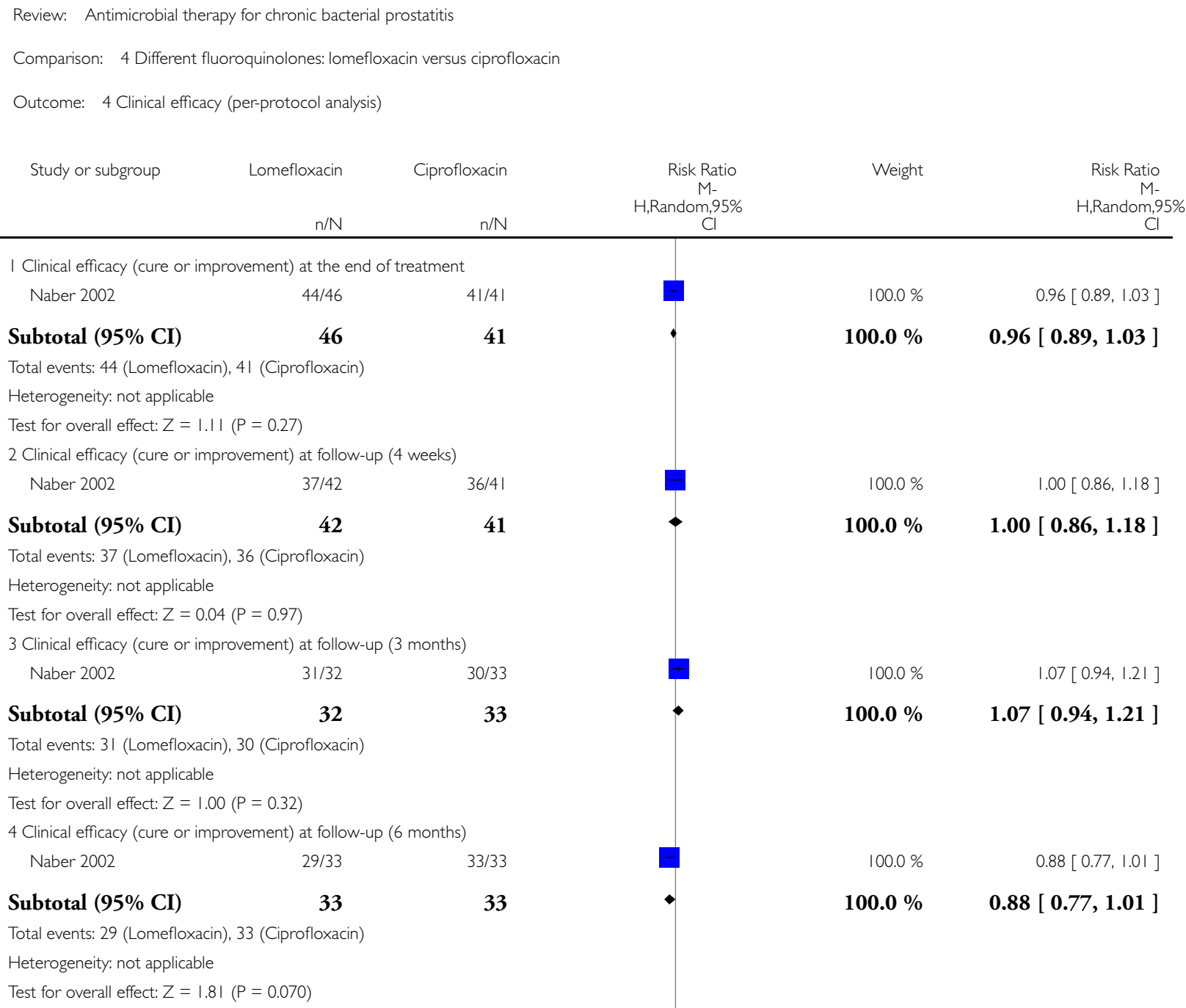

$\mathrm{n} / \mathrm{N}$

$46 \quad 41$

Subtotal (95\% CI)

Total events: 44 (Lomefloxacin), 4 I (Ciprofloxacin)

Heterogeneity: not applicable

Test for overall effect: $Z=1.11(P=0.27)$

2 Clinical efficacy (cure or improvement) at follow-up (4 weeks)

Naber $2002 \quad 37 / 42 \quad 36 / 41$

$42 \quad 41$

Subtotal $(\mathbf{9 5 \%}$ CI)

42

41

Total events: 37 (Lomefloxacin), 36 (Ciprofloxacin)

Heterogeneity: not applicable

Test for overall effect: $Z=0.04(P=0.97)$

3 Clinical efficacy (cure or improvement) at follow-up ( 3 months)

Naber 2002

$31 / 32$

$30 / 33$

$00.0 \%$

$1.07[0.94,1.21]$

Subtotal (95\% CI)

32

33

Total events: 31 (Lomefloxacin), 30 (Ciprofloxacin)

Heterogeneity: not applicable

Test for overall effect: $Z=1.00(P=0.32)$

4 Clinical efficacy (cure or improvement) at follow-up (6 months)

Naber 2002

29/33

$33 / 33$

33

33

Subtotal $(95 \%$ CI)

33

Total events: 29 (Lomefloxacin), 33 (Ciprofloxacin)

Heterogeneity: not applicable

Test for overall effect: $Z=1.81(P=0.070)$

$100.0 \%$

$100.0 \%$

$100.0 \%$

$100.0 \%$

$0.88[0.77,1.01]$

$100.0 \%$

$1.07[0.94,1.21]$

$\checkmark$

$0.88[0.77,1.01]$ 
Analysis 4.5. Comparison 4 Different fluoroquinolones: lomefloxacin versus ciprofloxacin, Outcome 5 Adverse effects of treatment.

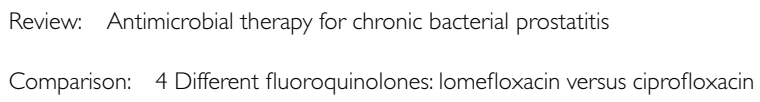

Subtotal (95\% CI)

3

Total events: 12 (Lomefloxacin), 14 (Ciprofloxacin)

Heterogeneity: not applicable

Test for overall effect: $Z=0.54(P=0.59)$

2 Gastrointestinal adverse effects

$$
\text { Naber } 2002
$$

\section{Subtotal (95\% CI)}

Total events: 5 (Lomefloxacin), 8 (Ciprofloxacin)

Heterogeneity: not applicable

Test for overall effect: $Z=0.93(P=0.35)$

3 Headache

Naber 2002

Subtotal (95\% CI)

Total events: I (Lomefloxacin), I (Ciprofloxacin)

Heterogeneity: not applicable

Test for overall effect: $Z=0.03(P=0.98)$

4 Dizziness

$$
\text { Naber } 2002
$$

Subtotal (95\% CI)

Total events: I (Lomefloxacin), 0 (Ciprofloxacin)

Heterogeneity: not applicable

Test for overall effect: $Z=0.65(P=0.52)$

5 Dry mouth

$$
\text { Naber } 2002
$$

Subtotal (95\% CI)

Total events: 2 (Lomefloxacin), 0 (Ciprofloxacin)

Heterogeneity: not applicable

Test for overall effect: $Z=1.02(P=0.31)$

6 Insomnia

$$
\text { Naber } 2002
$$

0/93

89

$0 / 89$

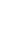

89

$14 / 89$
89

$+$

$\sqrt{2}$

89

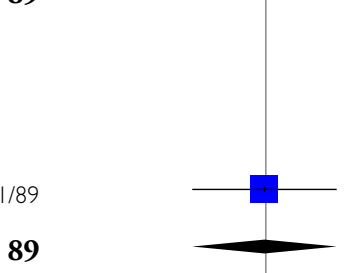

89

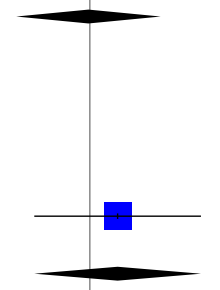

89

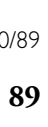

189

9

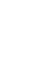

$100.0 \%$

$100.0 \%$

$100.0 \%$

$100.0 \%$

$100.0 \%$

$100.0 \%$

$100.0 \%$

$100.0 \%$

$100.0 \%$

$4.79[0.23,98.35]$

$\begin{array}{rr}100.0 \% & \mathbf{4 . 7 9}[\mathbf{0 . 2 3}, 98.35] \\ 100.0 \% & 0.32[0.01,7.73] \\ \\ \text { (Continued . . ) }\end{array}$

Antimicrobial therapy for chronic bacterial prostatitis (Review)

Copyright $\subset 2013$ The Cochrane Collaboration. Published by John Wiley \& Sons, Ltd. 


\begin{tabular}{|c|c|c|c|c|c|}
\hline Study or subgroup & Lomefloxacin & Ciprofloxacin & $\begin{array}{c}\text { Risk Ratio } \\
\text { M- } \\
\text { H,Random,95\% } \\
\mathrm{Cl} \\
\end{array}$ & Weight & $\begin{array}{c}\text { (... Continued) } \\
\text { Risk Ratio } \\
\text { M- } \\
\text { H,Random, , } 5 \% \\
\text { CI } \\
\end{array}$ \\
\hline Subtotal $(95 \%$ CI $)$ & 93 & 89 & & $100.0 \%$ & $0.32[0.01,7.73]$ \\
\hline \multicolumn{6}{|c|}{ Total events: 0 (Lomefloxacin), I (Ciprofloxacin) } \\
\hline \multicolumn{6}{|c|}{ Heterogeneity: not applicable } \\
\hline \multicolumn{6}{|c|}{ Test for overall effect: $Z=0.70(P=0.48)$} \\
\hline \multicolumn{6}{|c|}{7 Hyperglycemia } \\
\hline Naber 2002 & ।/93 & $0 / 89$ & 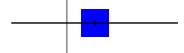 & $100.0 \%$ & $2.87[0.12,69.59]$ \\
\hline Subtotal $(95 \% \mathrm{CI})$ & 93 & 89 & & $100.0 \%$ & $2.87[0.12,69.59]$ \\
\hline \multicolumn{6}{|c|}{ Total events: I (Lomefloxacin), O (Ciprofloxacin) } \\
\hline \multicolumn{6}{|c|}{ Heterogeneity: not applicable } \\
\hline \multicolumn{6}{|c|}{ Test for overall effect: $Z=0.65(P=0.52)$} \\
\hline \multicolumn{6}{|c|}{8 Dermal toxicity } \\
\hline Naber 2002 & 1/93 & 0/89 & & $100.0 \%$ & $2.87[0.12,69.59]$ \\
\hline Subtotal $(95 \% \mathrm{CI})$ & 93 & 89 & & $100.0 \%$ & $2.87[0.12,69.59]$ \\
\hline \multicolumn{6}{|c|}{ Total events: I (Lomefloxacin), O (Ciprofloxacin) } \\
\hline \multicolumn{6}{|c|}{ Heterogeneity: not applicable } \\
\hline \multicolumn{6}{|c|}{ Test for overall effect: $Z=0.65(P=0.52)$} \\
\hline \multicolumn{6}{|c|}{9 Abnormal semen } \\
\hline Naber 2002 & 1/93 & 0/89 & & $100.0 \%$ & $2.87[0.12,69.59]$ \\
\hline Subtotal $(95 \% \mathrm{CI})$ & 93 & 89 & & $100.0 \%$ & $2.87[0.12,69.59]$ \\
\hline \multicolumn{6}{|c|}{ Total events: I (Lomefloxacin), O (Ciprofloxacin) } \\
\hline \multicolumn{6}{|c|}{ Heterogeneity: not applicable } \\
\hline \multicolumn{6}{|c|}{ Test for overall effect: $Z=0.65(P=0.52)$} \\
\hline \multicolumn{6}{|c|}{10 Upper respiratory tract infection } \\
\hline Naber 2002 & 0/93 & $4 / 89$ & & $100.0 \%$ & $0.11[0.01,1.95]$ \\
\hline Subtotal $(95 \% \mathrm{CI})$ & 93 & 89 & & $100.0 \%$ & $0.11[0.01,1.95]$ \\
\hline \multicolumn{6}{|c|}{ Total events: 0 (Lomefloxacin), 4 (Ciprofloxacin) } \\
\hline \multicolumn{6}{|c|}{ Heterogeneity: not applicable } \\
\hline Test for overall effect: $Z=$ & $P=0.13)$ & & & & \\
\hline
\end{tabular}


Analysis 5.I. Comparison 5 Different fluoroquinolones: lomefloxacin versus comparator fluoroquinolone, Outcome I Microbiological efficacy - pathogen eradication at follow-up (6 months).

Review: Antimicrobial therapy for chronic bacterial prostatitis

Comparison: 5 Different fluoroquinolones: lomefloxacin versus comparator fluoroquinolone

Outcome: I Microbiological efficacy - pathogen eradication at follow-up (6 months)

\begin{tabular}{|c|c|c|c|c|c|}
\hline Study or subgroup & Lomefloxacin & $\begin{array}{l}\text { Other } \\
\text { fluoro- } \\
\text { quinolone }\end{array}$ & Risk Ratio & Weight & Risk Ratio \\
\hline & $n / N$ & $n / N$ & M-H,Fixed,95\% Cl & & M-H,Fixed,95\% Cl \\
\hline Koff 1996 & $12 / 18$ & $9 / 15$ & 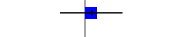 & $21.2 \%$ & $1.11[0.66,1.88]$ \\
\hline Naber 2002 & $34 / 42$ & $36 / 41$ & & $78.8 \%$ & $0.92[0.77,1.11]$ \\
\hline
\end{tabular}

Total (95\% CI)

60

56

$100.0 \%$

$0.96[0.80,1.16]$

Total events: 46 (Lomefloxacin), 45 (Other fluoroquinolone)

Heterogeneity: $\mathrm{Chi}^{2}=0.49, \mathrm{df}=\mathrm{I}(\mathrm{P}=0.48) ; \mathrm{I}^{2}=0.0 \%$

Test for overall effect: $Z=0.40(P=0.69)$

Test for subgroup differences: Not applicable

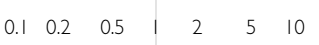

Favors other fluoroquinolone Favors lomefloxacin 
Analysis 5.2. Comparison 5 Different fluoroquinolones: lomefloxacin versus comparator fluoroquinolone, Outcome 2 Adverse effects of treatment.

Review: Antimicrobial therapy for chronic bacterial prostatitis

Comparison: 5 Different fluoroquinolones: lomefloxacin versus comparator fluoroquinolone

Outcome: 2 Adverse effects of treatment

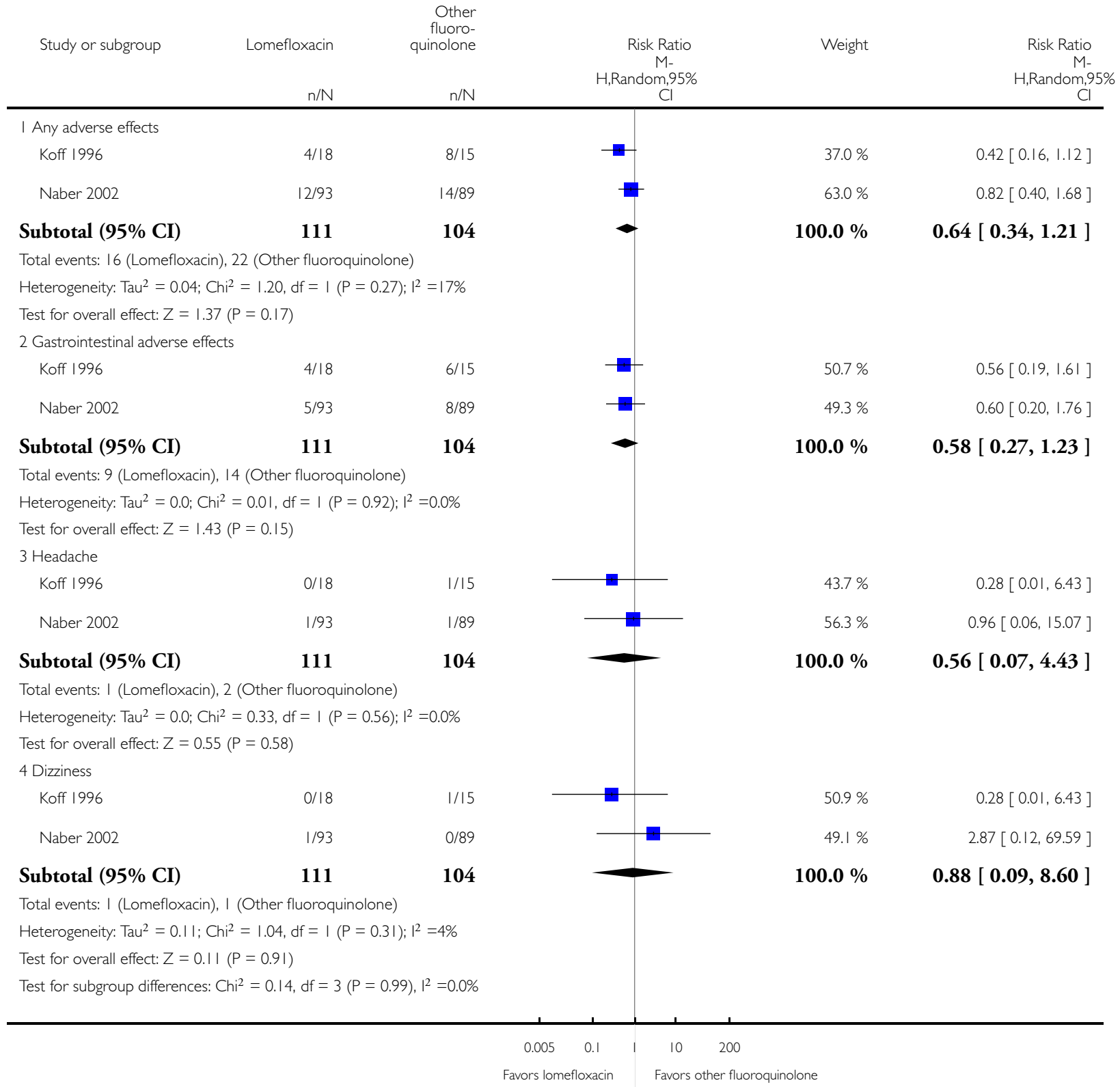

Antimicrobial therapy for chronic bacterial prostatitis (Review) 
Analysis 6.1. Comparison 6 Different fluoroquinolones: ciprofloxacin versus comparator fluoroquinolone, Outcome I Microbiological efficacy - pathogen eradication at the end of treatment (fixed-effect model).

Review: Antimicrobial therapy for chronic bacterial prostatitis

Comparison: 6 Different fluoroquinolones: ciprofloxacin versus comparator fluoroquinolone

Outcome: I Microbiological efficacy - pathogen eradication at the end of treatment (fixed-effect model)

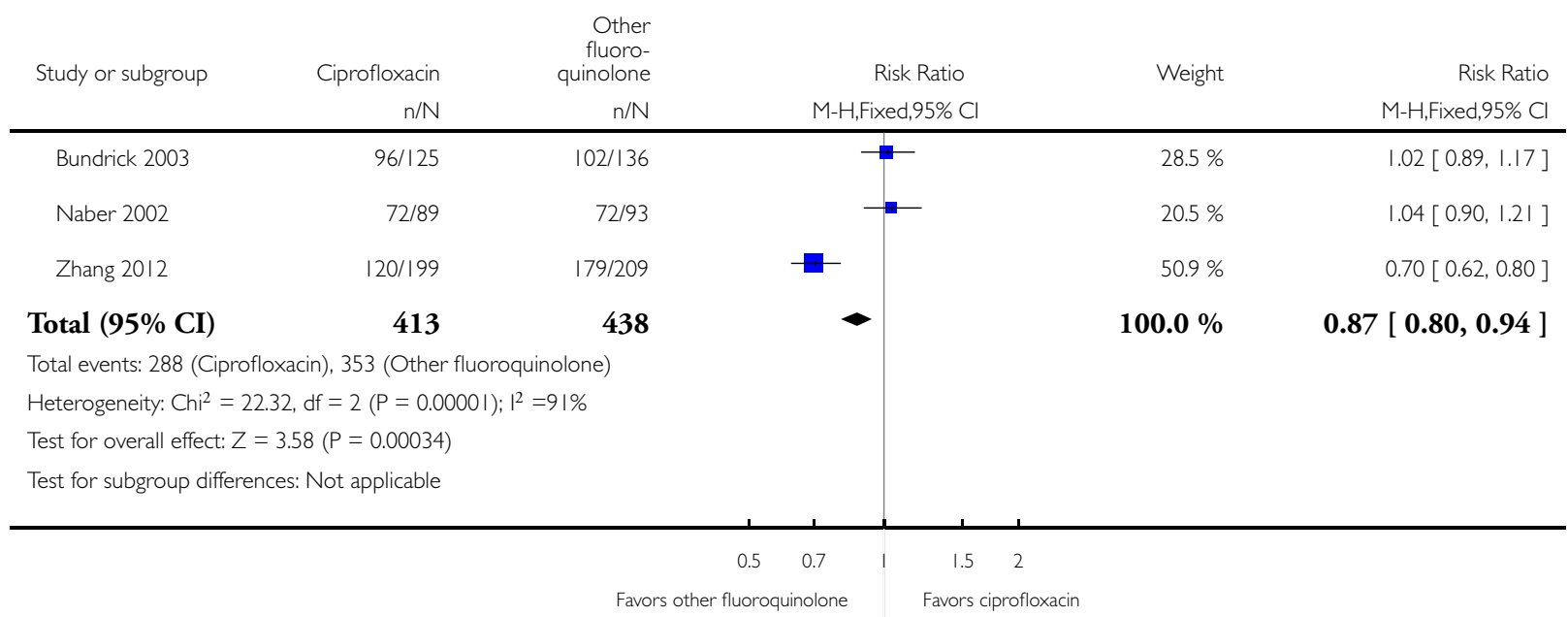


Analysis 6.2. Comparison 6 Different fluoroquinolones: ciprofloxacin versus comparator fluoroquinolone, Outcome 2 Microbiological efficacy - pathogen eradication at the end of treatment (random-effects model).

Review: Antimicrobial therapy for chronic bacterial prostatitis

Comparison: 6 Different fluoroquinolones: ciprofloxacin versus comparator fluoroquinolone

Outcome: 2 Microbiological efficacy - pathogen eradication at the end of treatment (random-effects model)

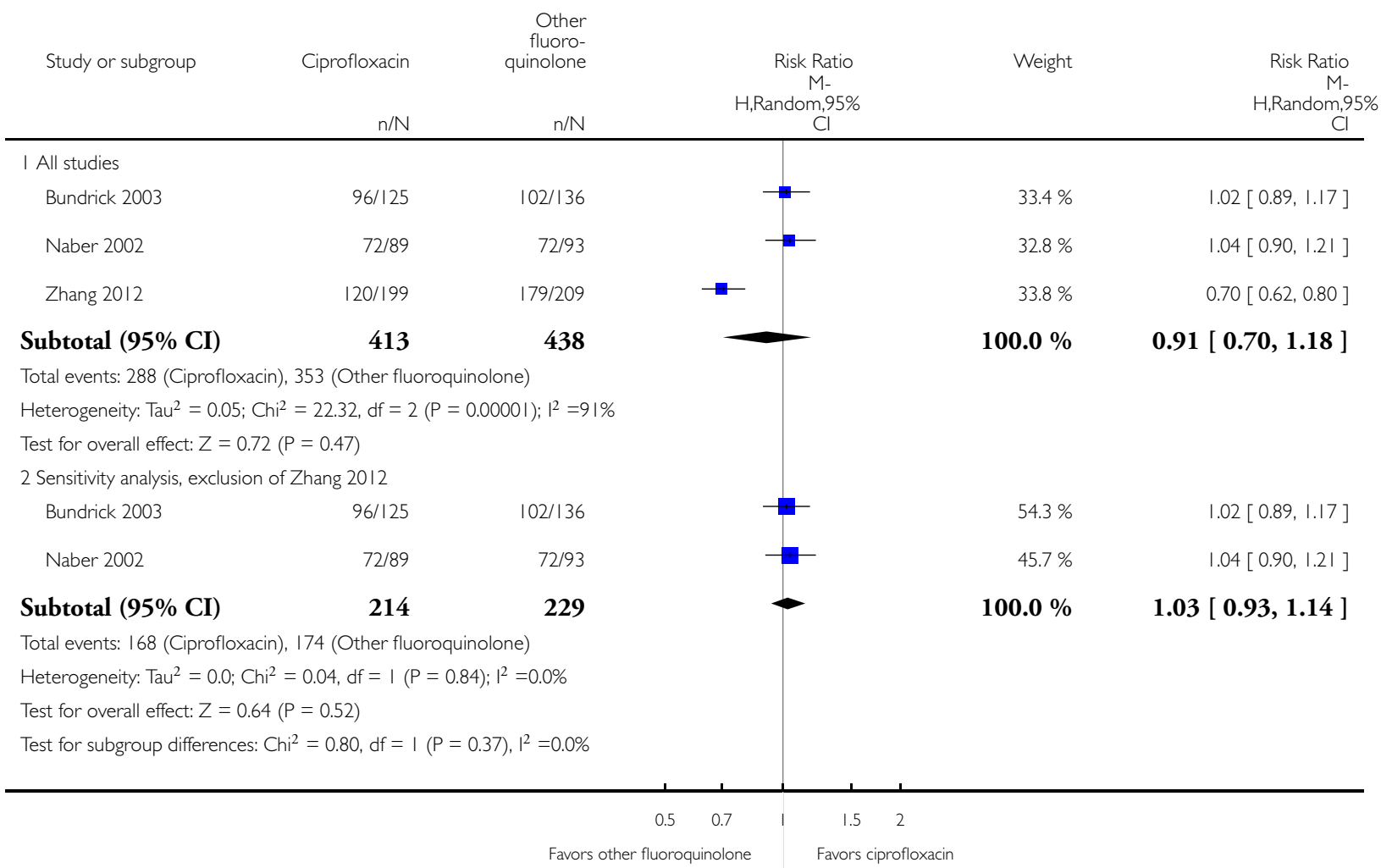


Analysis 6.3. Comparison 6 Different fluoroquinolones: ciprofloxacin versus comparator fluoroquinolone, Outcome 3 Clinical efficacy.

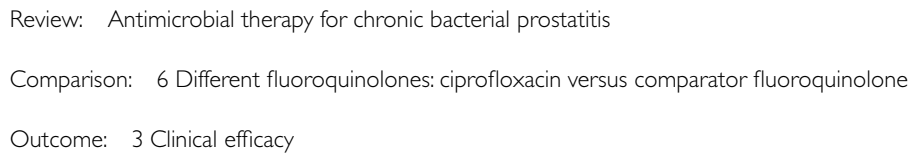

Favors other fluoroquinolone Favors ciprofloxacin 
Analysis 6.4. Comparison 6 Different fluoroquinolones: ciprofloxacin versus comparator fluoroquinolone, Outcome 4 Adverse effects of treatment.

Review: Antimicrobial therapy for chronic bacterial prostatitis

Comparison: 6 Different fluoroquinolones: ciprofloxacin versus comparator fluoroquinolone

Outcome: 4 Adverse effects of treatment

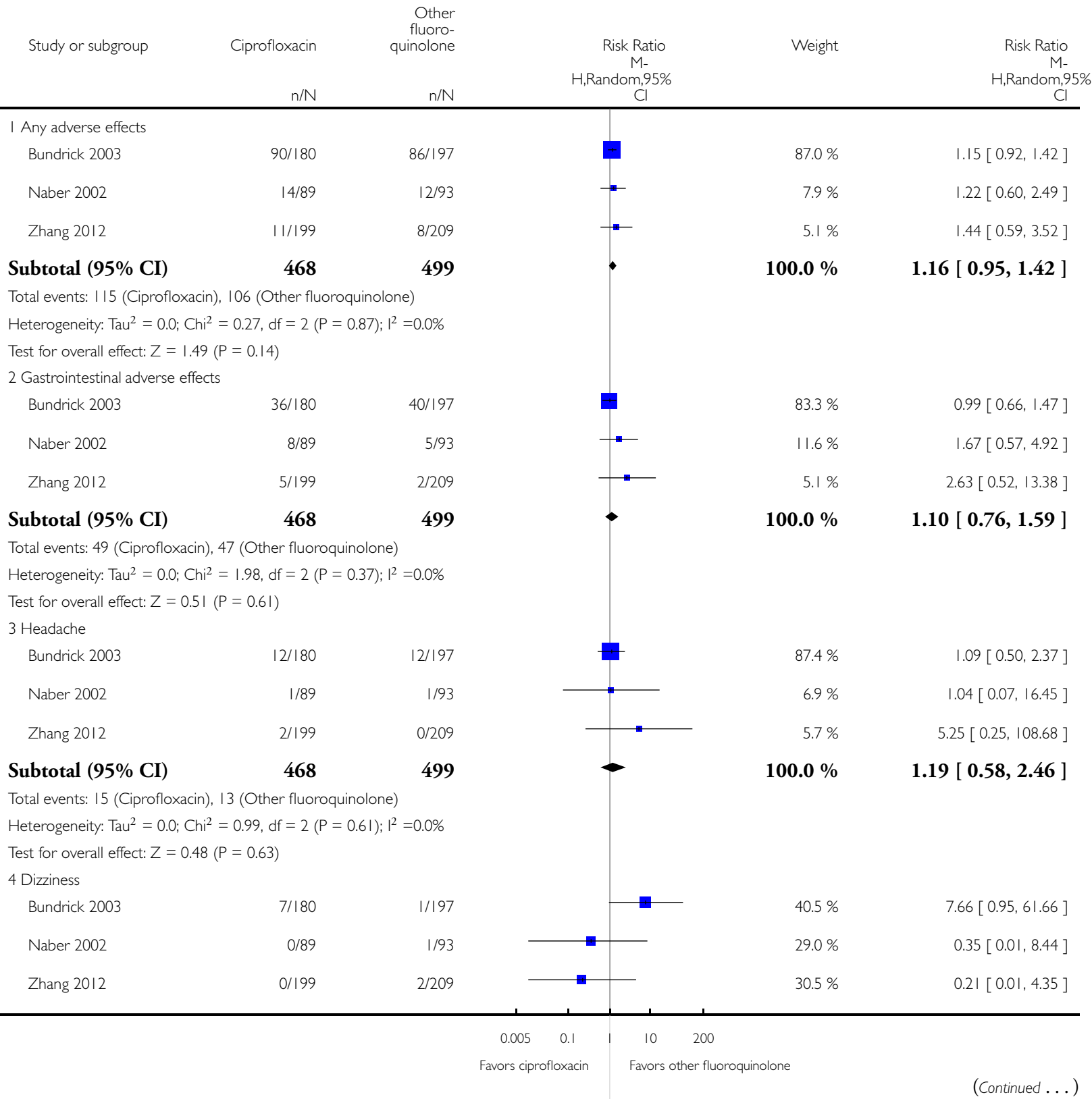


$\mathrm{n} / \mathrm{N}$

$\mathrm{n} / \mathrm{N}$

H,Random,95\%

H,Random,95\%

Total events: 7 (Ciprofloxacin), 4 (Other fluoroquinolone)

Heterogeneity: $\mathrm{Tau}^{2}=2.7 \mathrm{I} ; \mathrm{Ch}^{2}=4.79, \mathrm{df}=2(\mathrm{P}=0.09) ; \mathrm{I}^{2}=58 \%$

Test for overall effect: $Z=0.03(P=0.97)$

5 Dermal toxicity

Bundrick 2003

$5 / 180$

2/197

Naber 2002

$0 / 89$

1/93

Zhang 2012

$1 / 199$

1/209

Subtotal (95\% CI)

468

499

499

Cl

Total events: 6 (Ciprofloxacin), 4 (Other fluoroquinolone)

Heterogeneity: $\mathrm{Tau}^{2}=0.0 ; \mathrm{Chi}^{2}=1.39, \mathrm{df}=2(\mathrm{P}=0.50) ; \mathrm{I}^{2}=0.0 \%$

Test for overall effect: $Z=0.71(P=0.48)$

Test for subgroup differences: $\mathrm{Chi}^{2}=0.33, \mathrm{df}=4(\mathrm{P}=0.99), \mathrm{I}^{2}=0.0 \%$

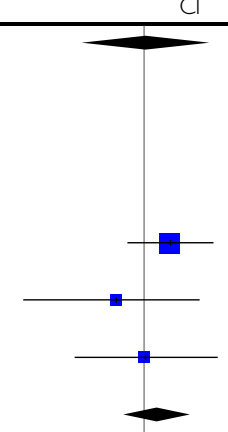

$100.0 \%$

$1.04[0.09,12.02$ ]

$62.2 \%$

$16.2 \%$

$21.6 \%$

$100.0 \%$
$2.74[0.54,13.93]$

$0.35[0.01,8.44]$

$1.05[0.07,16.68]$

$1.59[0.44,5.75]$ 
Analysis 7.I. Comparison 7 Different fluoroquinolones: levofloxacin versus comparator fluoroquinolone, Outcome I Microbiological efficacy - pathogen eradication (fixed-effect model).

Review: Antimicrobial therapy for chronic bacterial prostatitis

Comparison: 7 Different fluoroquinolones: levofloxacin versus comparator fluoroquinolone

Outcome: I Microbiological efficacy - pathogen eradication (fixed-effect model)

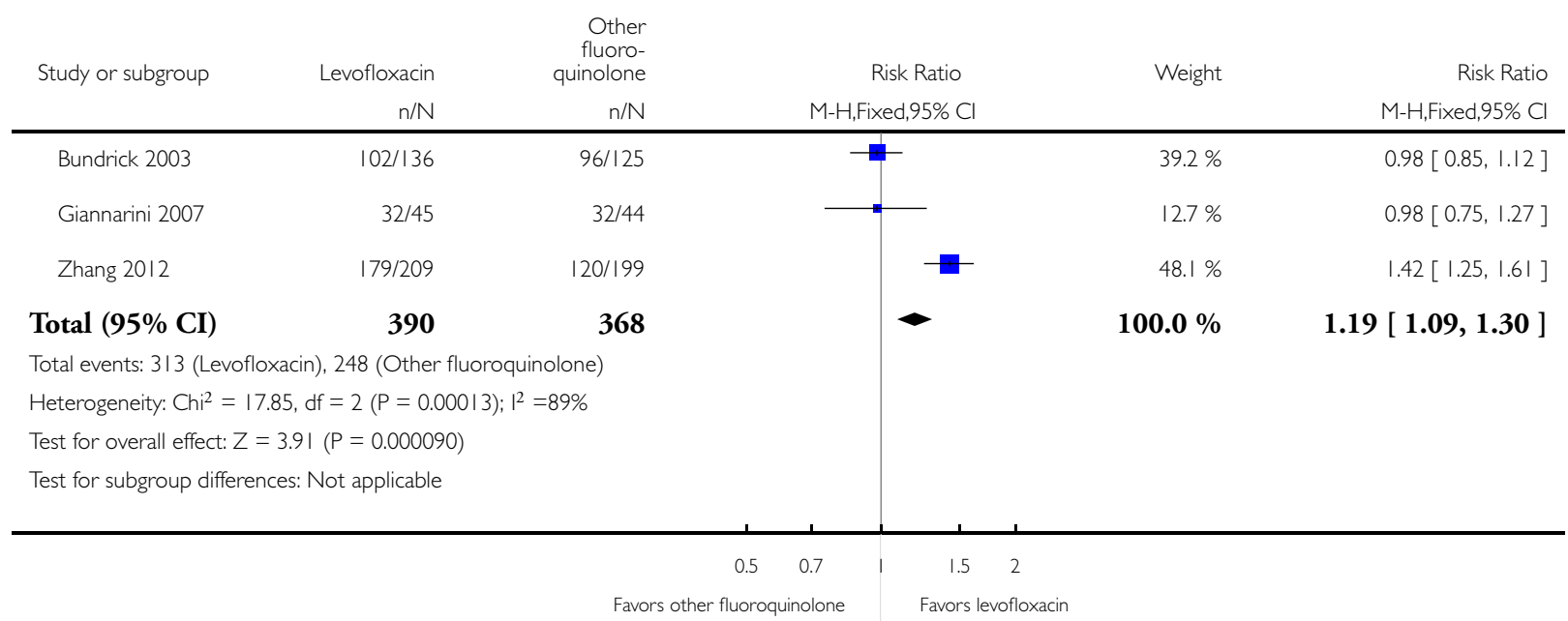


Analysis 7.2. Comparison 7 Different fluoroquinolones: levofloxacin versus comparator fluoroquinolone, Outcome 2 Microbiological efficacy - pathogen eradication (random-effects model).

Review: Antimicrobial therapy for chronic bacterial prostatitis

Comparison: 7 Different fluoroquinolones: levofloxacin versus comparator fluoroquinolone

Outcome: 2 Microbiological efficacy - pathogen eradication (random-effects model)

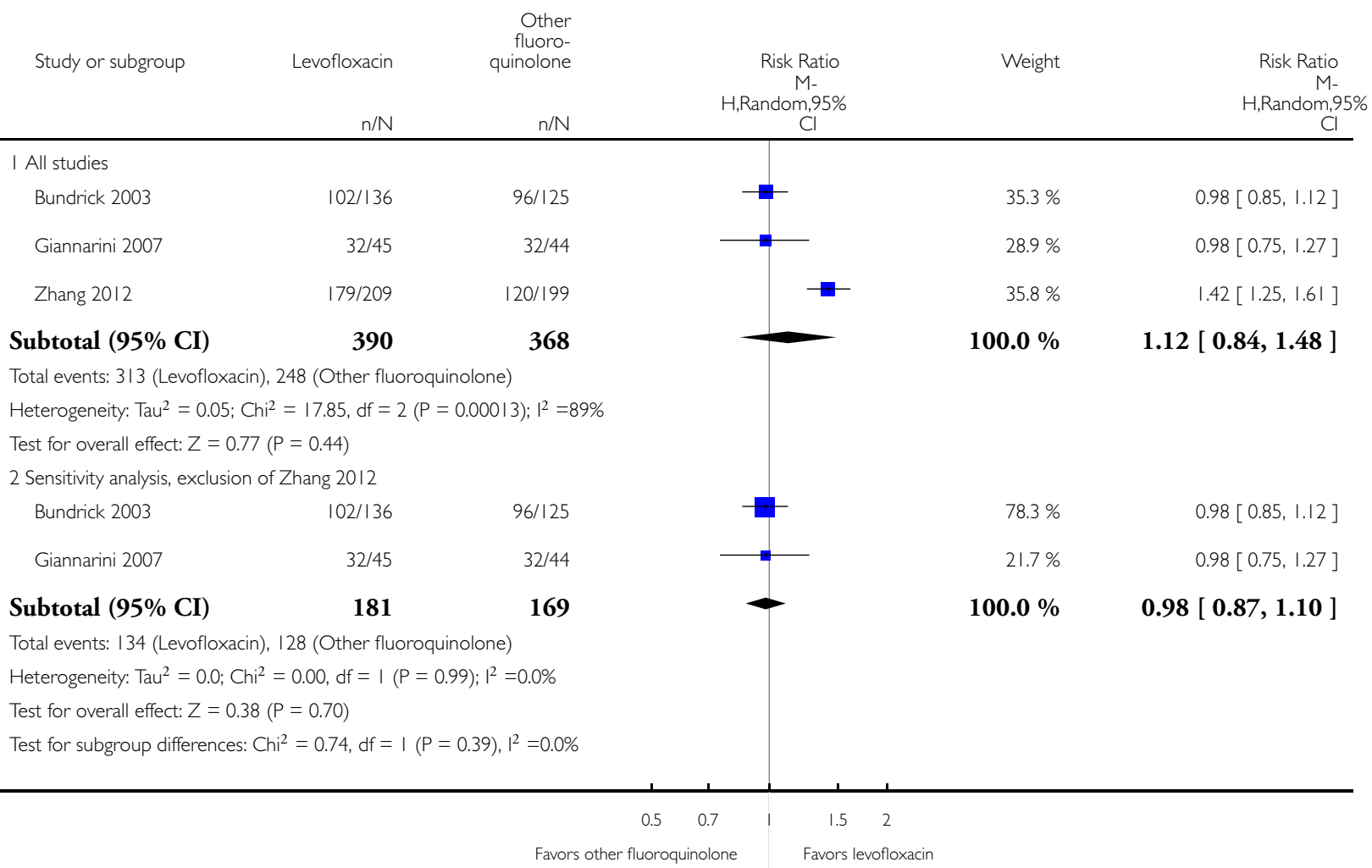




\section{Analysis 7.3. Comparison 7 Different fluoroquinolones: levofloxacin versus comparator fluoroquinolone, Outcome 3 Adverse effects of treatment.}

Review: Antimicrobial therapy for chronic bacterial prostatitis

Comparison: 7 Different fluoroquinolones: levofloxacin versus comparator fluoroquinolone

Outcome: 3 Adverse effects of treatment

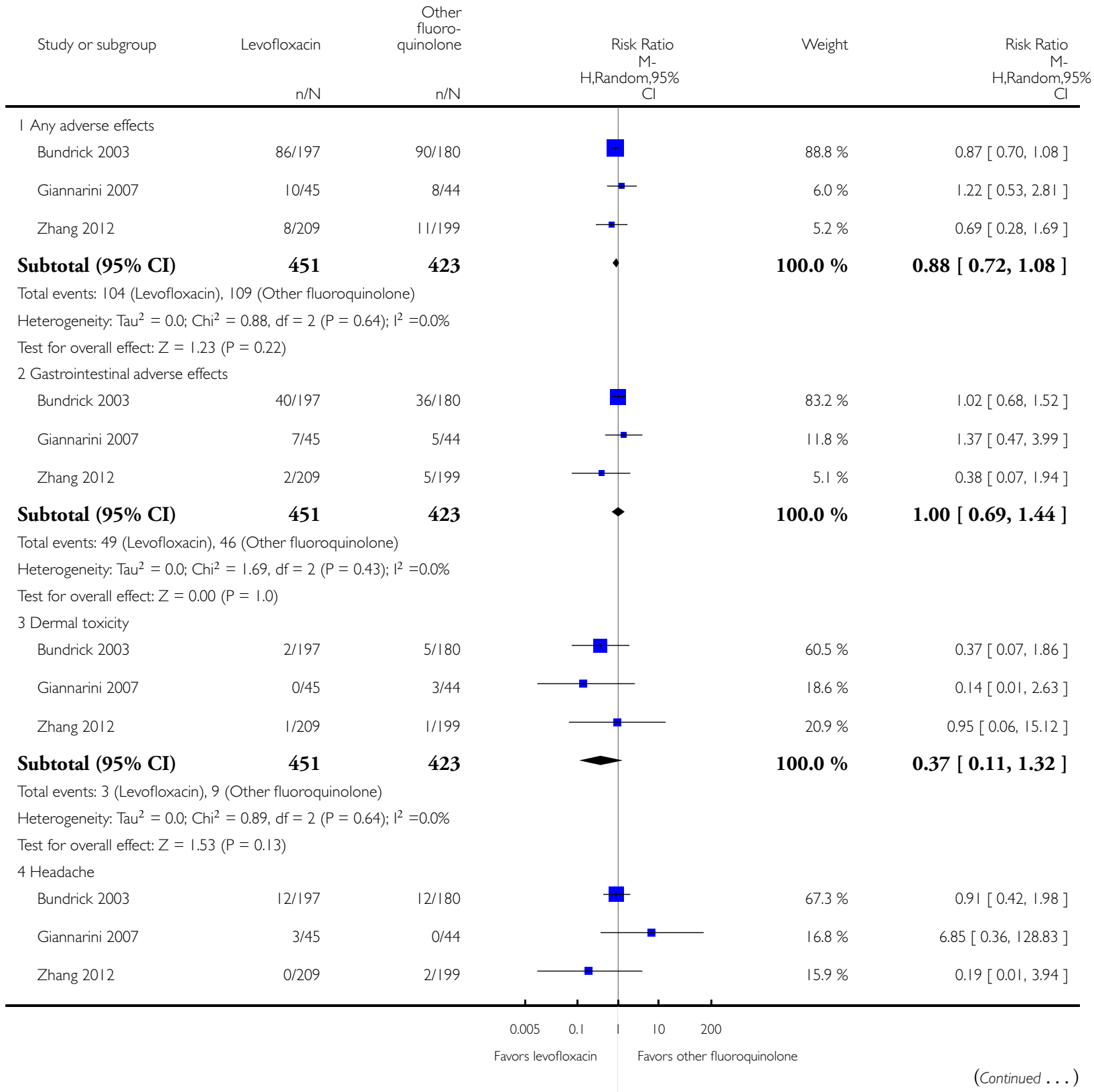




\begin{tabular}{|c|c|c|c|c|c|}
\hline Study or subgroup & Levofloxacin & $\begin{array}{r}\text { Other } \\
\text { fluoro- } \\
\text { quinolone } \\
\mathrm{n} / \mathrm{N}\end{array}$ & $\begin{array}{r}\text { Risk Ratio } \\
\text { M- } \\
\text { H,Random,95\% } \\
\text { Cl }\end{array}$ & Weight & $\begin{array}{c}\text { Risk Ratio } \\
\text { M- } \\
\text { H,Random,95\% } \\
\text { Cl }\end{array}$ \\
\hline Subtotal $(95 \% \mathrm{CI})$ & 451 & 423 & $\longrightarrow$ & $100.0 \%$ & $1.00[0.26,3.80]$ \\
\hline \multicolumn{6}{|c|}{ Total events: I5 (Levofloxacin), I4 (Other fluoroquinolone) } \\
\hline \multicolumn{6}{|c|}{ Heterogeneity: $\operatorname{Tau}^{2}=0.54 ; \mathrm{Chi}^{2}=2.84, \mathrm{df}=2(\mathrm{P}=0.24) ; \mathrm{I}^{2}=30 \%$} \\
\hline \multicolumn{6}{|c|}{ Test for overall effect: $Z=0.00(P=1.0)$} \\
\hline \multicolumn{6}{|c|}{ Test for subgroup differences: $\mathrm{Chi}^{2}=2.24, \mathrm{df}=3(\mathrm{P}=0.52), \mathrm{I}^{2}=0.0 \%$} \\
\hline & & 0.005 & 0.1 & 200 & \\
\hline \multicolumn{6}{|c|}{ Favors levofloxacin } \\
\hline
\end{tabular}

Analysis 8.1. Comparison 8 Fluoroquinolone versus other antibacterial agent: prulifloxacin versus doxycycline in chlamydial prostatitis, Outcome I Microbiological efficacy - absence of Chlamydia trachomatis DNA and IgA at the end of treatment.

Review: Antimicrobial therapy for chronic bacterial prostatitis

Comparison: 8 Fluoroquinolone versus other antibacterial agent: prulifloxacin versus doxycycline in chlamydial prostatitis

Outcome: I Microbiological efficacy - absence of Chlamydia trachomatis DNA and IgA at the end of treatment

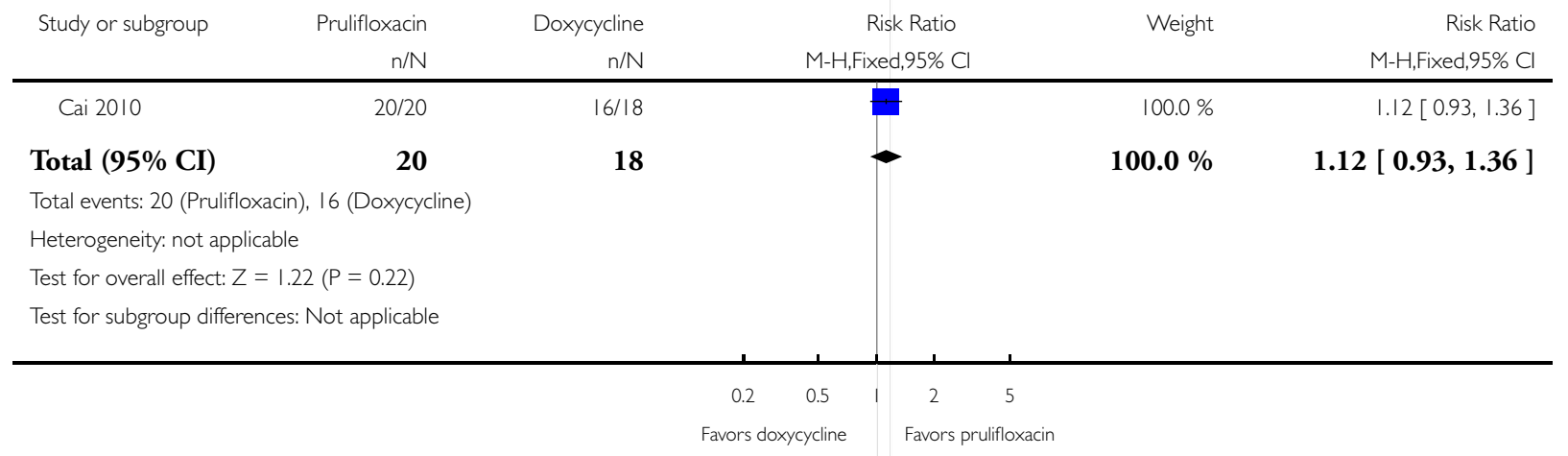


Analysis 8.2. Comparison 8 Fluoroquinolone versus other antibacterial agent: prulifloxacin versus doxycycline in chlamydial prostatitis, Outcome 2 Clinical efficacy - NIH-CPSI total score at the end of treatment.

Review: Antimicrobial therapy for chronic bacterial prostatitis

Comparison: 8 Fluoroquinolone versus other antibacterial agent: prulifloxacin versus doxycycline in chlamydial prostatitis

Outcome: 2 Clinical efficacy - NIH-CPSI total score at the end of treatment

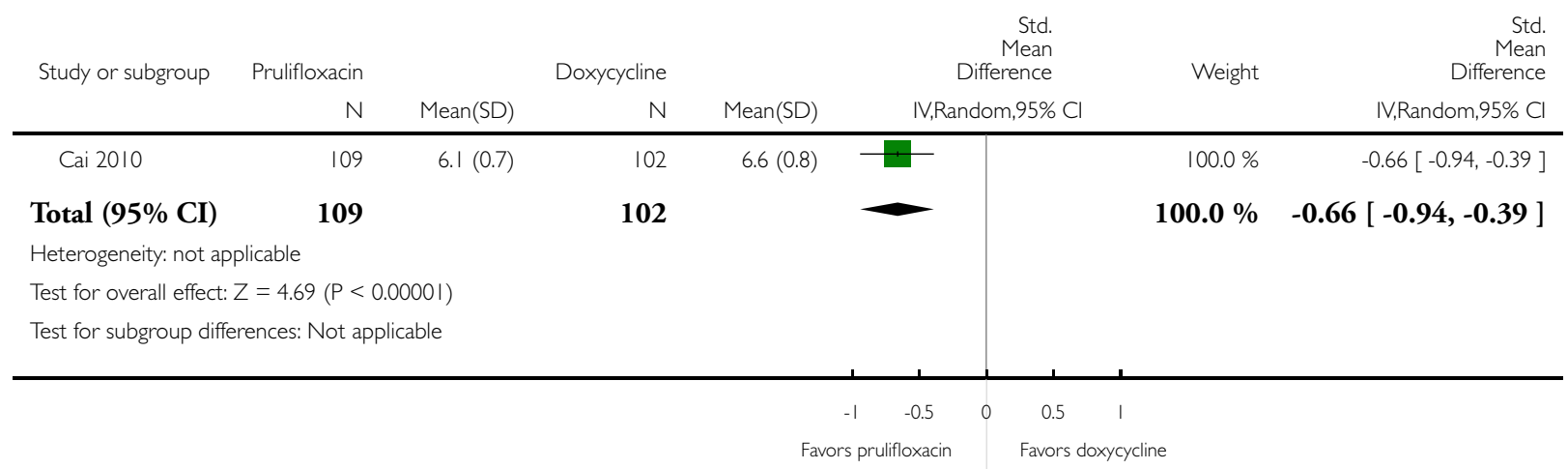

Analysis 8.3. Comparison 8 Fluoroquinolone versus other antibacterial agent: prulifloxacin versus doxycycline in chlamydial prostatitis, Outcome 3 Clinical efficacy - number of asymptomatic participants at the end of therapy.

Review: Antimicrobial therapy for chronic bacterial prostatitis

Comparison: 8 Fluoroquinolone versus other antibacterial agent: prulifloxacin versus doxycycline in chlamydial prostatitis

Outcome: 3 Clinical efficacy - number of asymptomatic participants at the end of therapy

\begin{tabular}{|c|c|c|c|c|c|}
\hline Study or subgroup & Prulifloxacin & Doxycycline & $\begin{array}{r}\text { Risk Ratio } \\
\text { M- } \\
\text { H,Random,95\% } \\
\mathrm{Cl} \\
\end{array}$ & Weight & $\begin{array}{c}\text { Risk Ratio } \\
\text { M- } \\
\text { H,Random,95\% } \\
\mathrm{Cl} \\
\end{array}$ \\
\hline Cai 2010 & $90 / 109$ & $81 / 102$ & 世 & $100.0 \%$ & $1.04[0.91,1.19]$ \\
\hline Total $(95 \%$ CI $)$ & 109 & 102 & - & $100.0 \%$ & $1.04[0.91,1.19]$ \\
\hline \multicolumn{6}{|c|}{ Total events: 90 (Prulifloxacin), 8I (Doxycycline) } \\
\hline \multicolumn{6}{|c|}{ Heterogeneity: not applicable } \\
\hline \multicolumn{6}{|c|}{ Test for overall effect: $Z=0.58(P=0.56)$} \\
\hline \multicolumn{6}{|c|}{ Test for subgroup differences: Not applicable } \\
\hline
\end{tabular}


Analysis 8.4. Comparison 8 Fluoroquinolone versus other antibacterial agent: prulifloxacin versus doxycycline in chlamydial prostatitis, Outcome 4 Adverse effects of treatment.

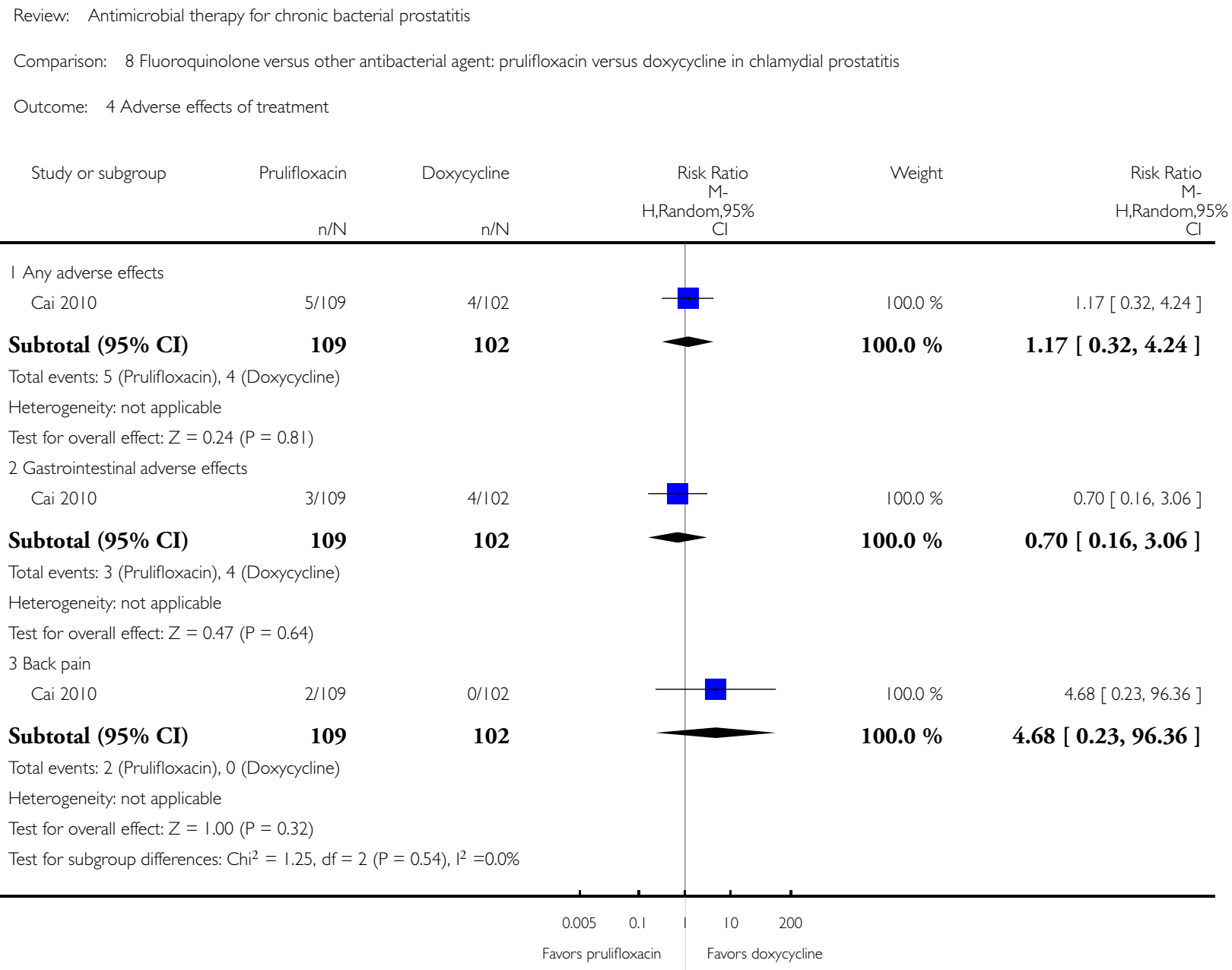


Analysis 9.1. Comparison 9 Fluoroquinolone versus other antibacterial agent: ofloxacin versus minocycline in ureaplasmal prostatitis, Outcome I Microbiological efficacy - pathogen eradication.

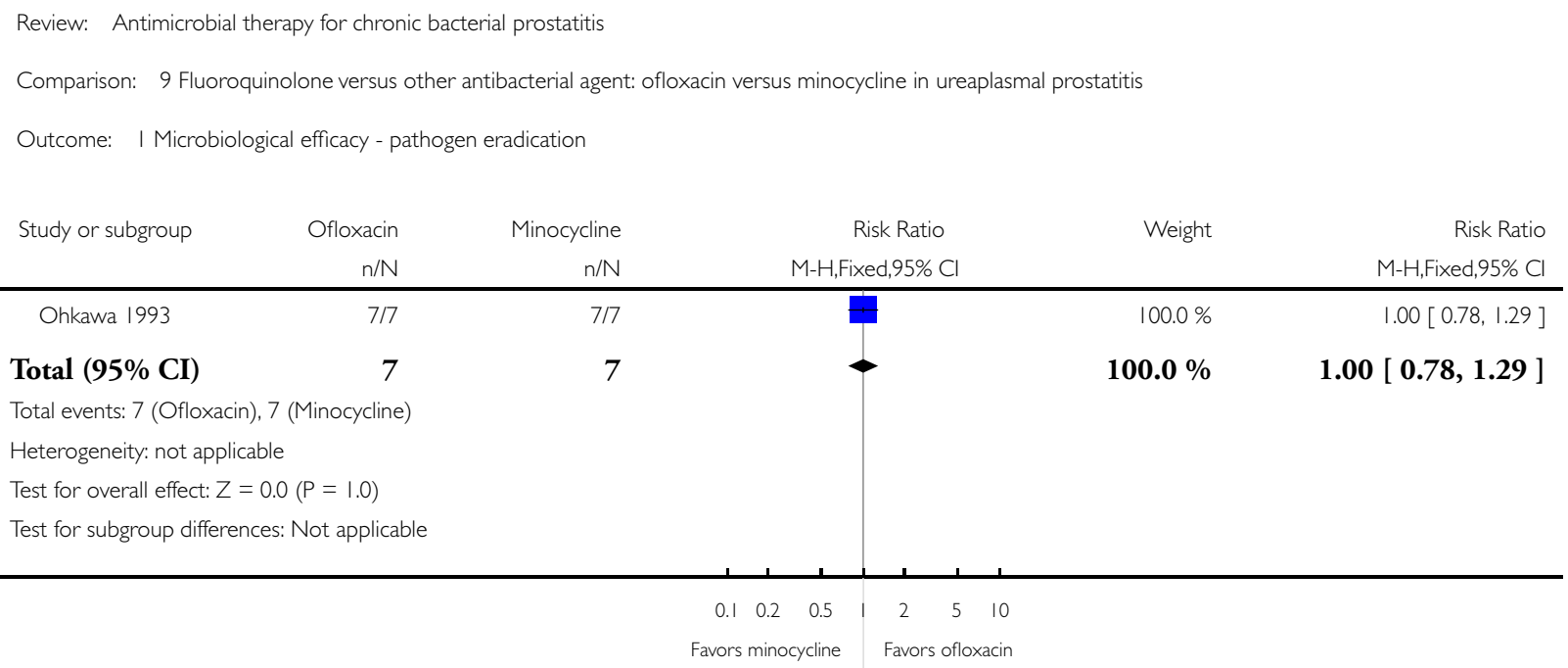

Analysis 9.2. Comparison 9 Fluoroquinolone versus other antibacterial agent: ofloxacin versus minocycline in ureaplasmal prostatitis, Outcome 2 Clinical efficacy (cure or improvement) at the end of treatment.

Review: Antimicrobial therapy for chronic bacterial prostatitis

Comparison: 9 Fluoroquinolone versus other antibacterial agent: ofloxacin versus minocycline in ureaplasmal prostatitis

Outcome: 2 Clinical efficacy (cure or improvement) at the end of treatment

$\begin{array}{llll}\text { Study or subgroup } & \text { Ofloxacin } & \text { Minocycline } & \text { Watio }\end{array}$

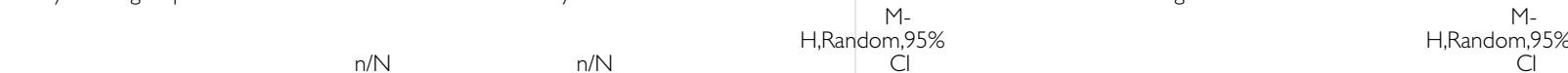

Ohkawa $1993 \quad 6 / 7$

$7 / 7 \quad 100.0 \%$
$0.87[0.59,1.26]$

Total (95\% CI) 7

Total events: 6 (Ofloxacin), 7 (Minocycline)

Heterogeneity: not applicable

Test for overall effect: $Z=0.74(P=0.46)$

Test for subgroup differences: Not applicable

7

$100.0 \%$

$0.87[0.59,1.26]$ 
Analysis 10.1. Comparison 10 Fluoroquinolone versus other antibacterial agent: ofloxacin versus carbenicillin, Outcome I Microbiological efficacy - pathogen eradication.

Review: Antimicrobial therapy for chronic bacterial prostatitis

Comparison: 10 Fluoroquinolone versus other antibacterial agent: ofloxacin versus carbenicillin

Outcome: I Microbiological efficacy - pathogen eradication

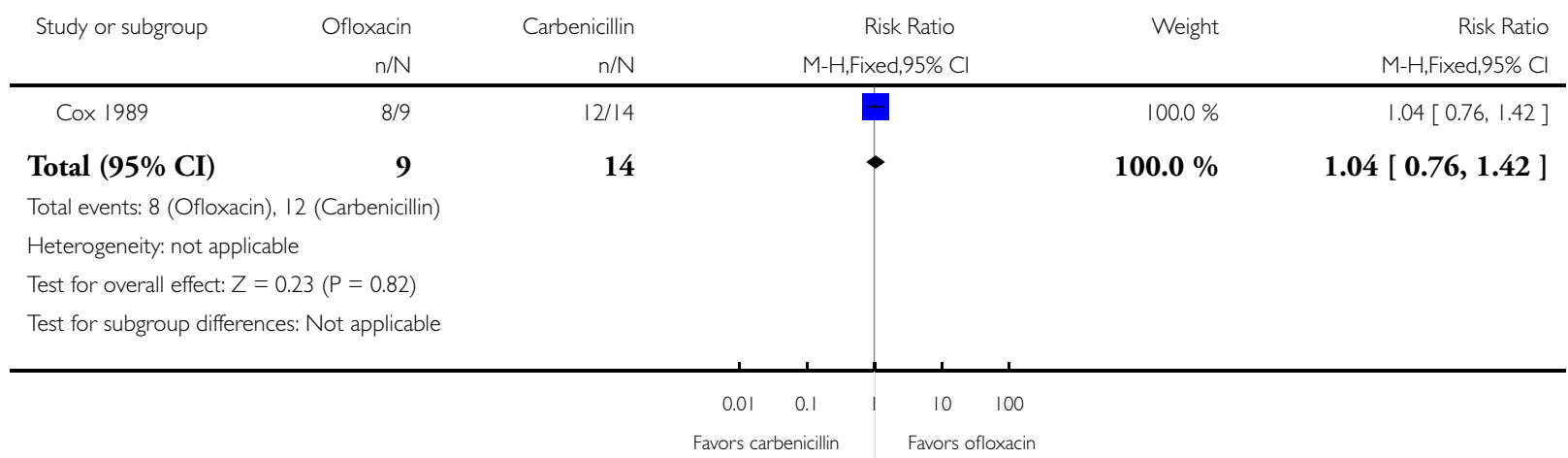

Analysis 10.2. Comparison 10 Fluoroquinolone versus other antibacterial agent: ofloxacin versus carbenicillin, Outcome 2 Clinical efficacy (cure or improvement) at the end of treatment.

Review: Antimicrobial therapy for chronic bacterial prostatitis

Comparison: 10 Fluoroquinolone versus other antibacterial agent: ofloxacin versus carbenicillin

Outcome: 2 Clinical efficacy (cure or improvement) at the end of treatment

$\begin{array}{lll}\mathrm{Cox} 1989 & \mathrm{n} / \mathrm{N} & \mathrm{n} / \mathrm{N}\end{array}$

$\mathrm{n} / \mathrm{N}-\mathrm{H}$, Random,

$\mathrm{M}$ - $95 \%$

9

$13 / 14$

$+$

Cl

14

$\checkmark$

$00.0 \%$

Weight

Risk Ratio

H,Random,95\%

Total (95\% CI)

nicillin)

Heterogeneity: not applicable

Test for overall effect: $Z=0.48(P=0.63)$

Test for subgroup differences: Not applicable

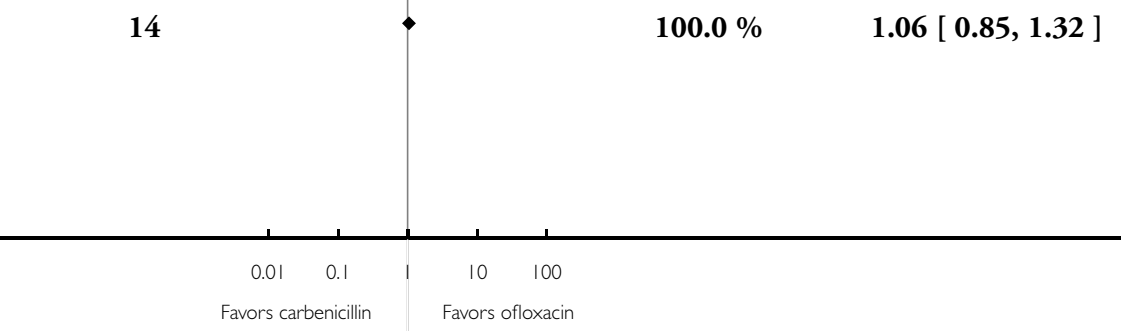


Analysis 10.3. Comparison 10 Fluoroquinolone versus other antibacterial agent: ofloxacin versus carbenicillin, Outcome 3 Adverse effects of treatment.

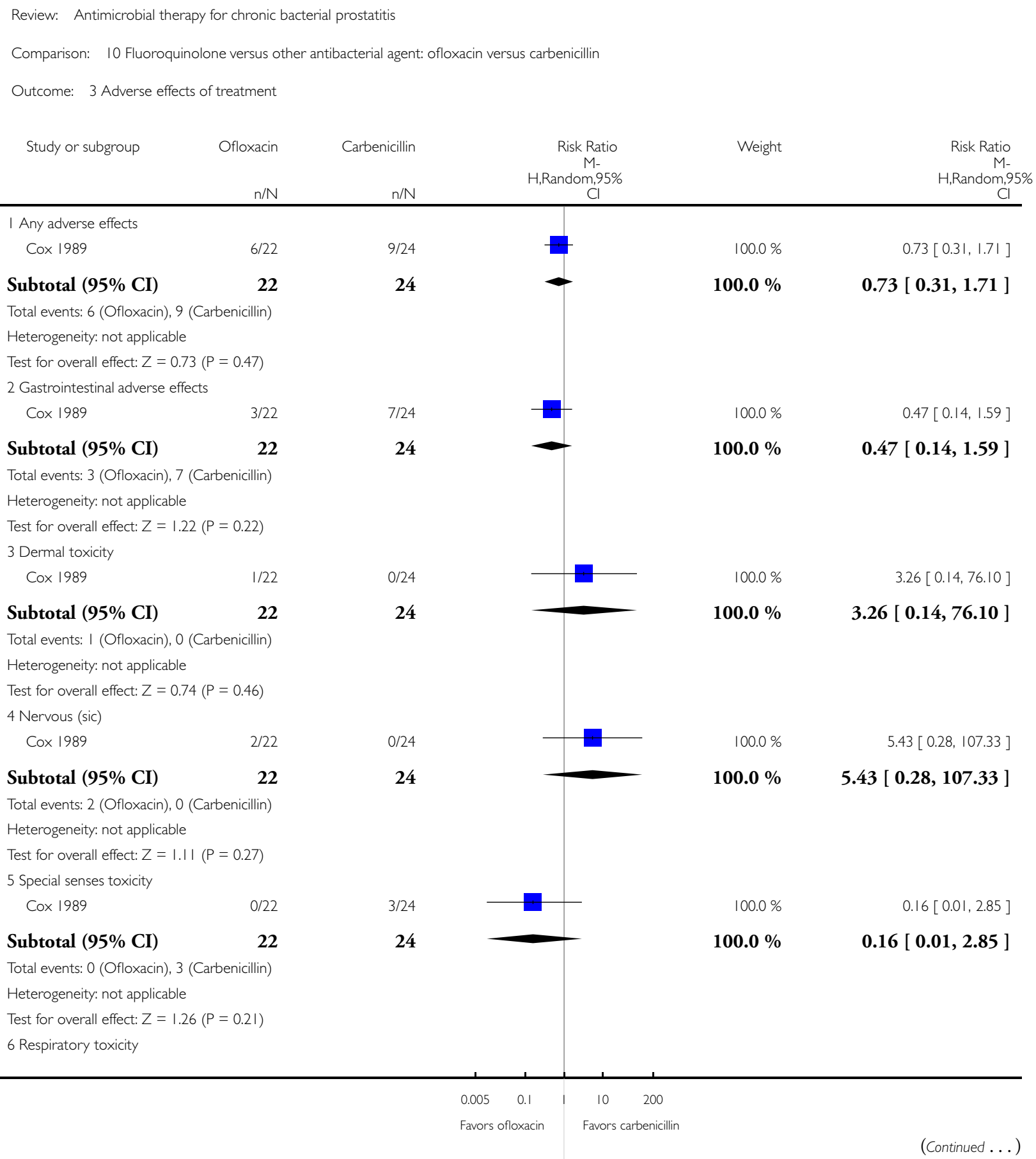




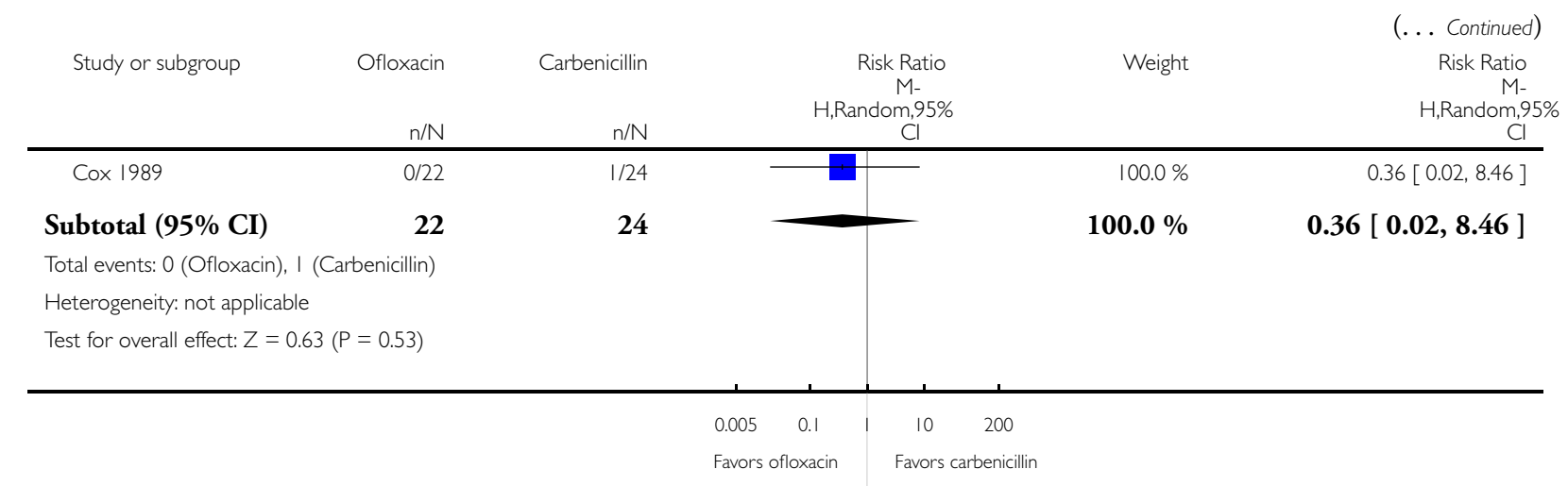

Analysis I I.I. Comparison I I Fluoroquinolone versus other antibacterial agent: lomefloxacin versus cotrimoxazole, Outcome I Microbiological efficacy.

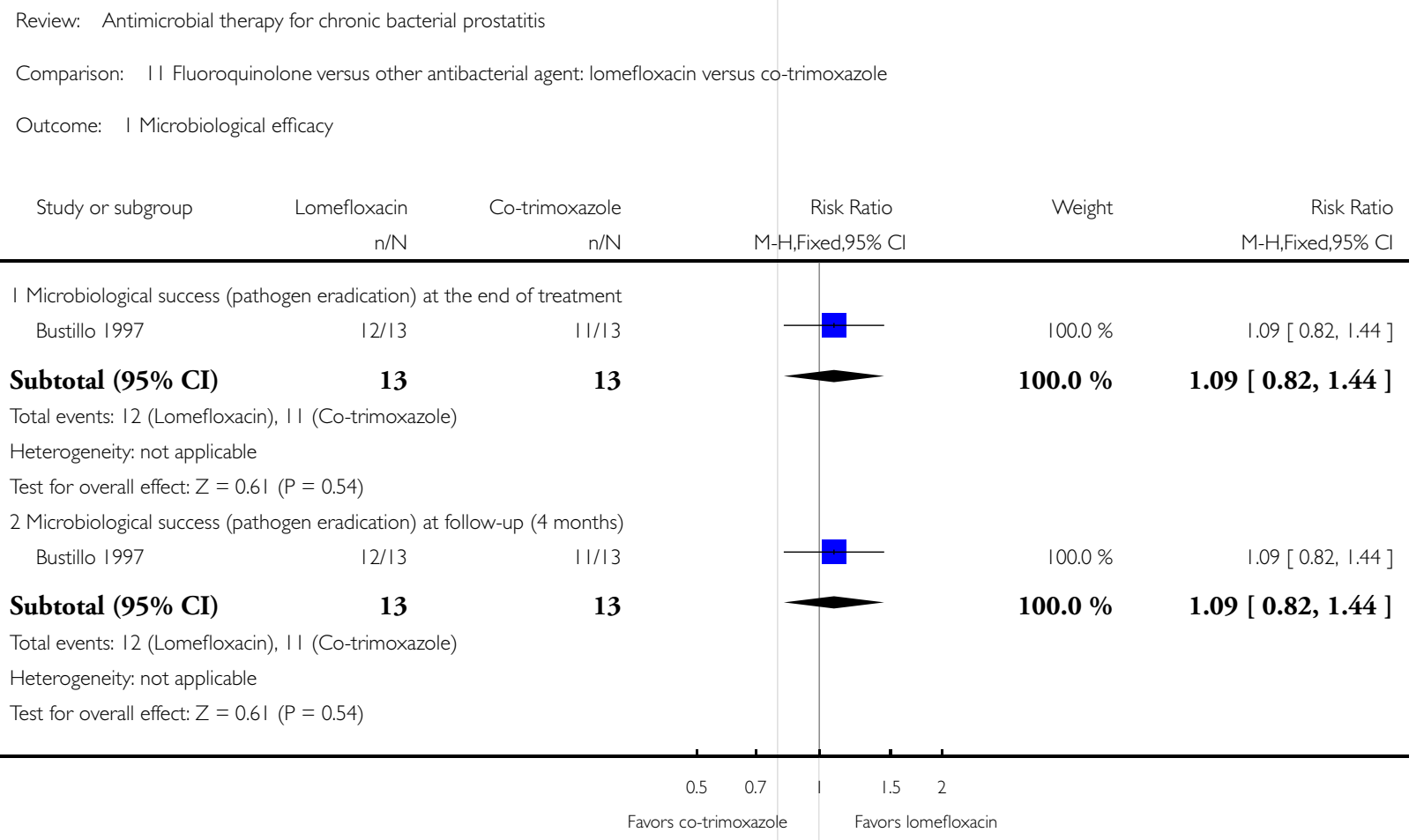


Analysis I I.2. Comparison I I Fluoroquinolone versus other antibacterial agent: lomefloxacin versus cotrimoxazole, Outcome 2 Clinical efficacy.

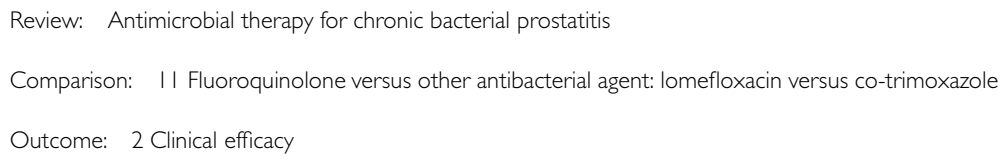

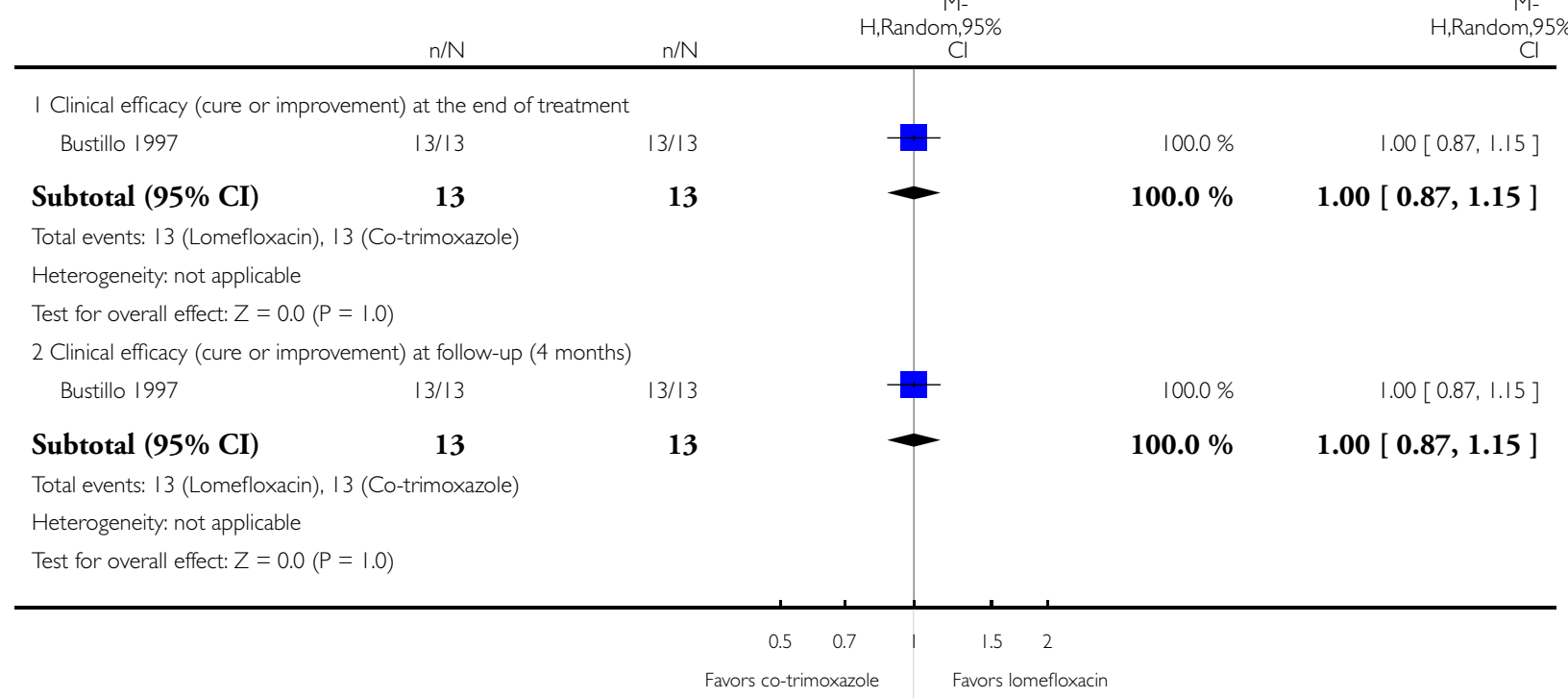


Analysis I I.3. Comparison I I Fluoroquinolone versus other antibacterial agent: lomefloxacin versus cotrimoxazole, Outcome 3 Adverse effects of treatment.

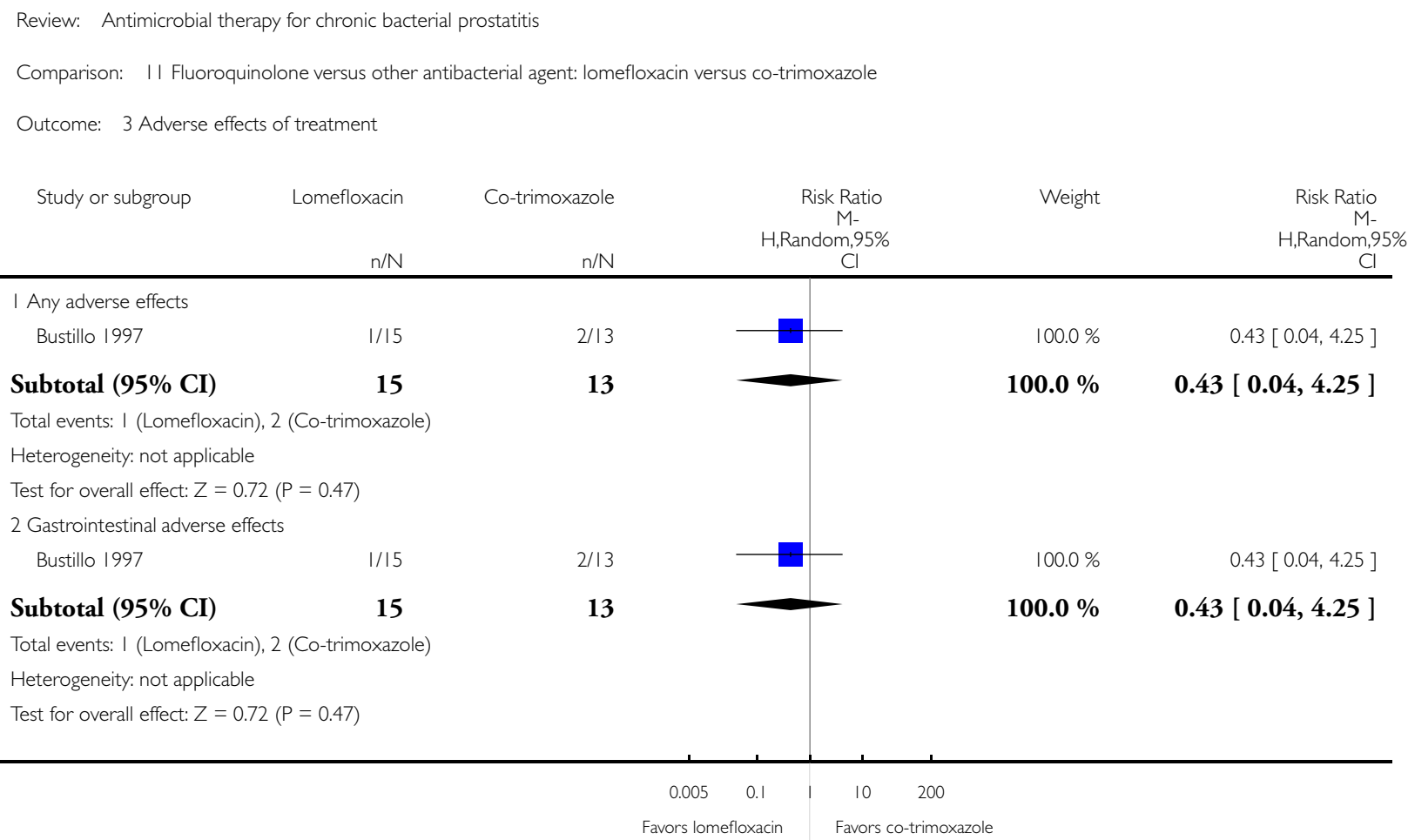


Analysis 12.I. Comparison I2 Fluoroquinolone versus other antibacterial agent: ciprofloxacin versus azithromycin in chlamydial prostatitis, Outcome I Microbiological efficacy (pathogen eradication) at the end of treatment.

Review: Antimicrobial therapy for chronic bacterial prostatitis

Comparison: 12 Fluoroquinolone versus other antibacterial agent: ciprofloxacin versus azithromycin in chlamydial prostatitis

Outcome: I Microbiological efficacy (pathogen eradication) at the end of treatment

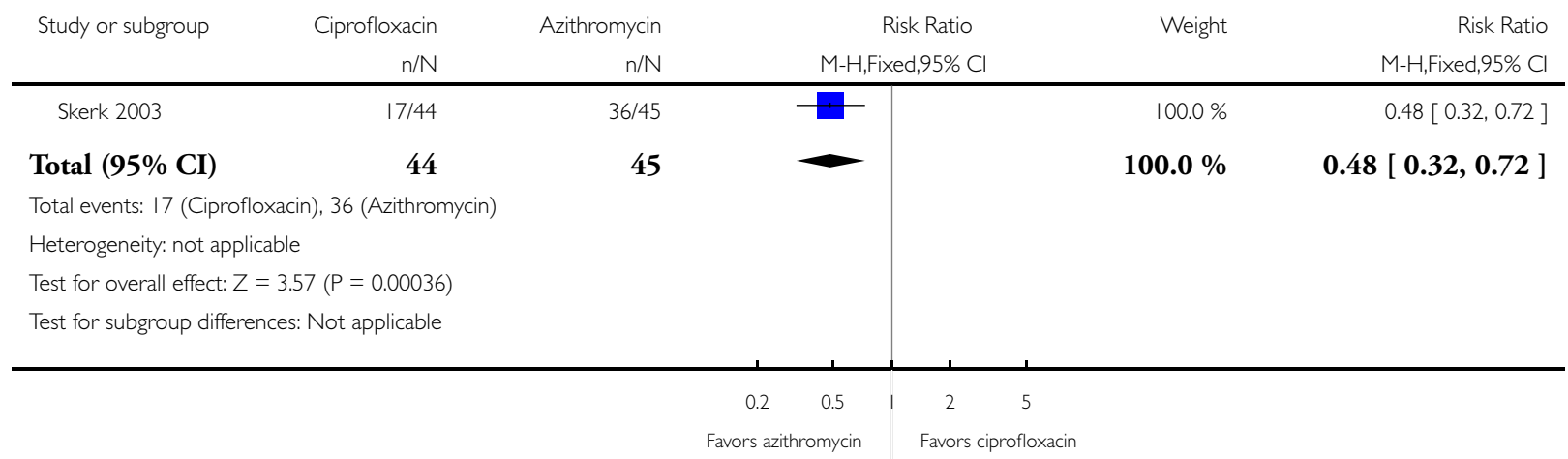

Analysis I2.2. Comparison I 2 Fluoroquinolone versus other antibacterial agent: ciprofloxacin versus azithromycin in chlamydial prostatitis, Outcome 2 Clinical efficacy (cure or improvement) at the end of treatment.

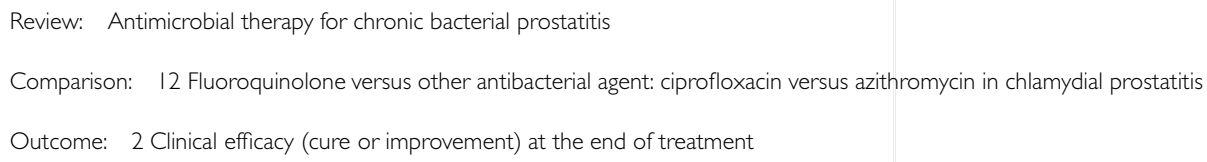

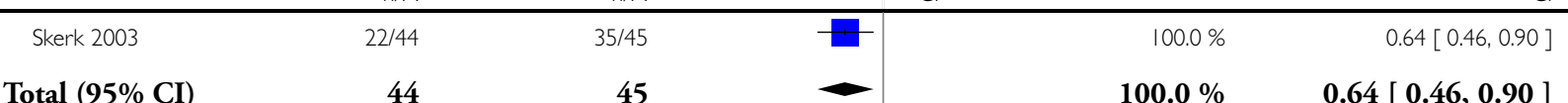

Total $(95 \% \mathrm{CI})$

44

45

$100.0 \%$

$0.64[0.46,0.90]$

Total events: 22 (Ciprofloxacin), 35 (Azithromycin)

Heterogeneity: not applicable

Test for overall effect: $Z=2.59(P=0.0096)$

Test for subgroup differences: Not applicable

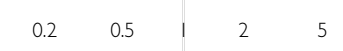

Favors azithromycin Favors ciprofloxacin 
Analysis I 2.3. Comparison I 2 Fluoroquinolone versus other antibacterial agent: ciprofloxacin versus azithromycin in chlamydial prostatitis, Outcome 3 Adverse effects of treatment.

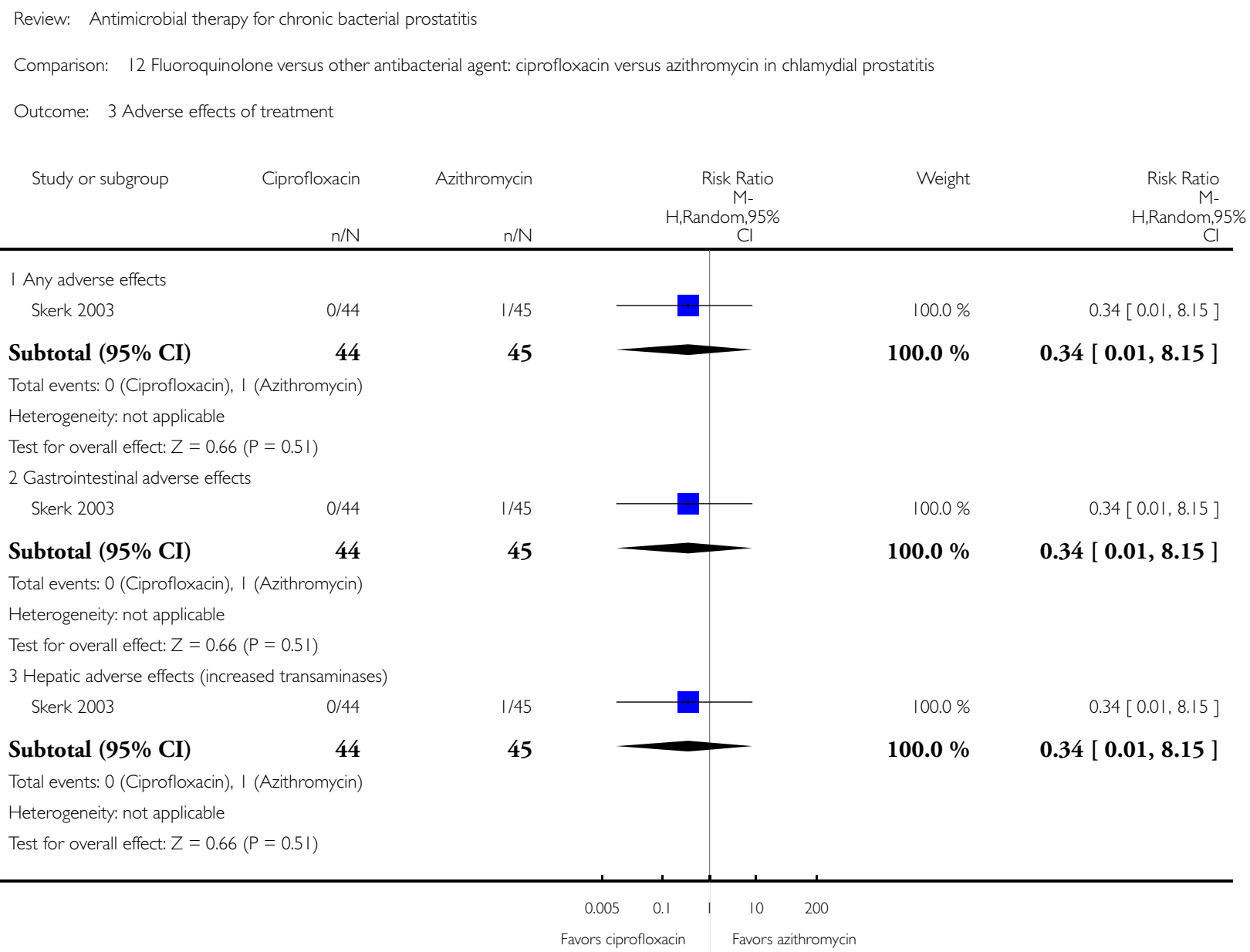


Analysis 13.1. Comparison 13 Non-fluoroquinolone antibacterial agents: minocycline versus cephalexin, Outcome I Microbiological efficacy (pathogen eradication and eradication plus superinfection) at the end of treatment.

Review: Antimicrobial therapy for chronic bacterial prostatitis

Comparison: 13 Non-fluoroquinolone antibacterial agents: minocycline versus cephalexin

Outcome: I Microbiological efficacy (pathogen eradication and eradication plus superinfection) at the end of treatment

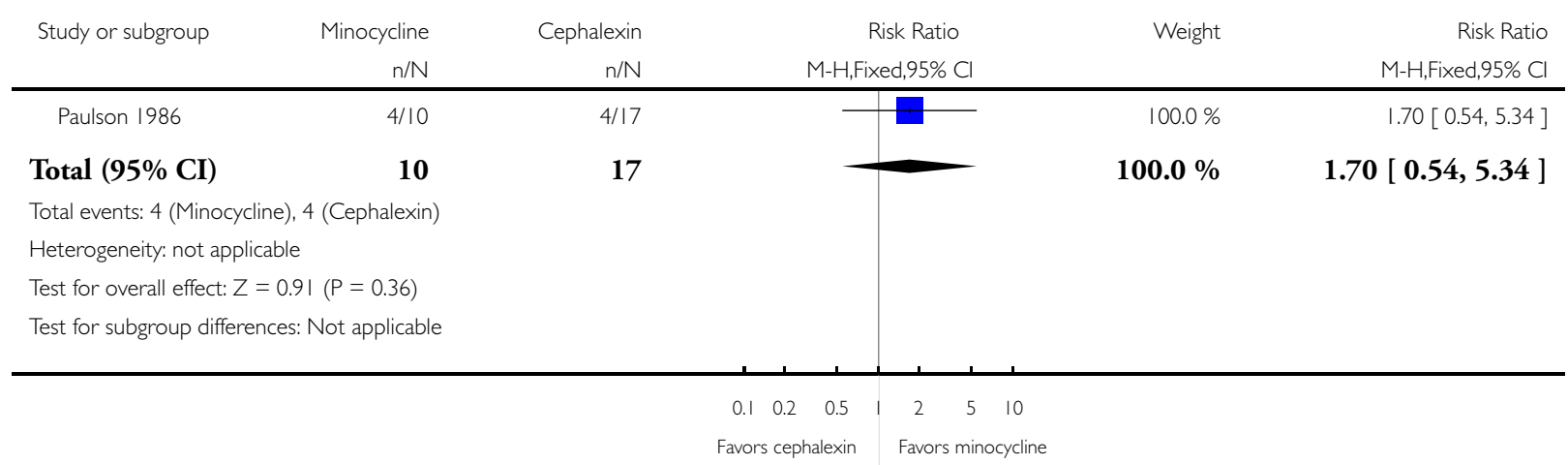

Analysis 13.2. Comparison 13 Non-fluoroquinolone antibacterial agents: minocycline versus cephalexin, Outcome 2 Clinical efficacy (cure or improvement) at the end of treatment.

Review: Antimicrobial therapy for chronic bacterial prostatitis

Comparison: 13 Non-fluoroquinolone antibacterial agents: minocycline versus cephalexin

Outcome: 2 Clinical efficacy (cure or improvement) at the end of treatment

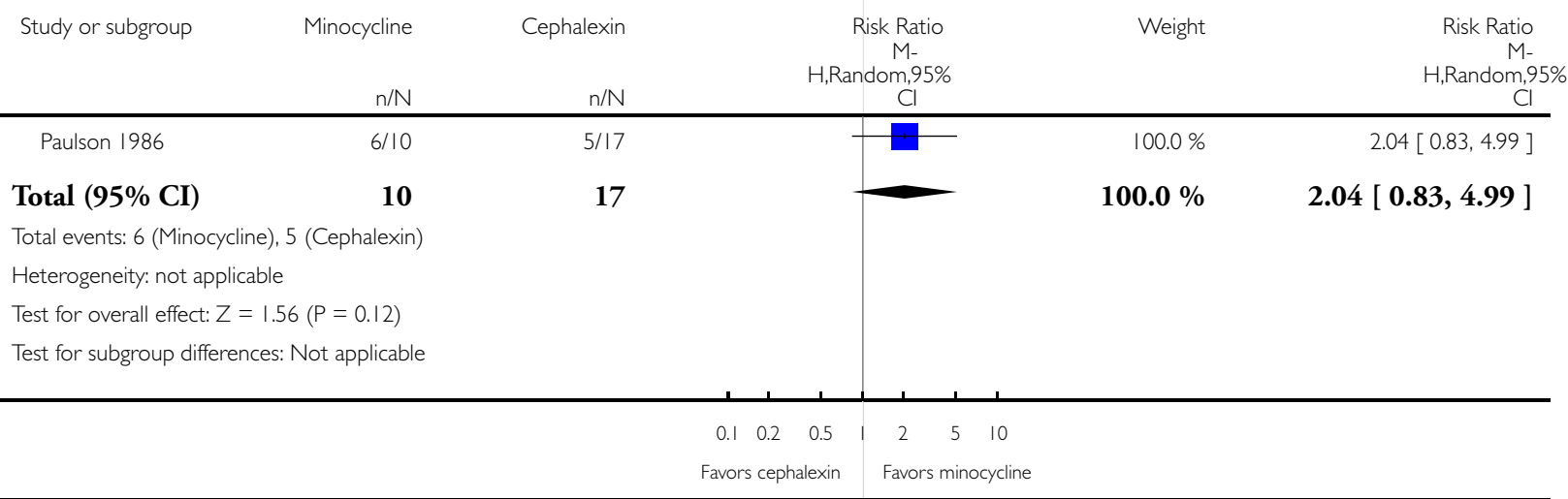

Antimicrobial therapy for chronic bacterial prostatitis (Review)

Copyright @ 2013 The Cochrane Collaboration. Published by John Wiley \& Sons, Ltd. 
Analysis 13.3. Comparison I 3 Non-fluoroquinolone antibacterial agents: minocycline versus cephalexin, Outcome 3 Microbiological recurrence.

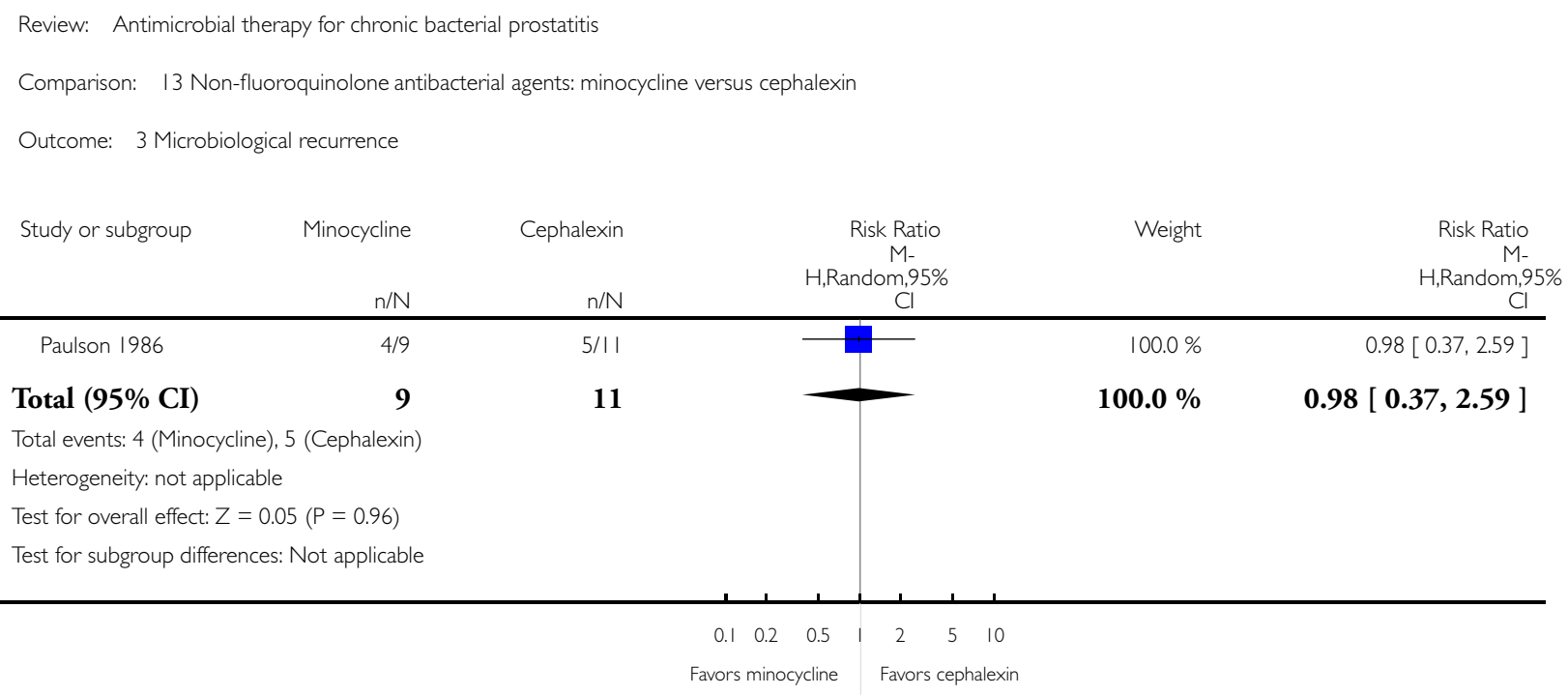


Analysis 14.I. Comparison I 4 Non-fluoroquinolone antibacterial agents: azithromycin versus clarithromycin in chlamydial prostatitis, Outcome I Microbiological efficacy (pathogen eradication) at the end of treatment.

Review: Antimicrobial therapy for chronic bacterial prostatitis

Comparison: 14 Non-fluoroquinolone antibacterial agents: azithromycin versus clarithromycin in chlamydial prostatitis

Outcome: I Microbiological efficacy (pathogen eradication) at the end of treatment

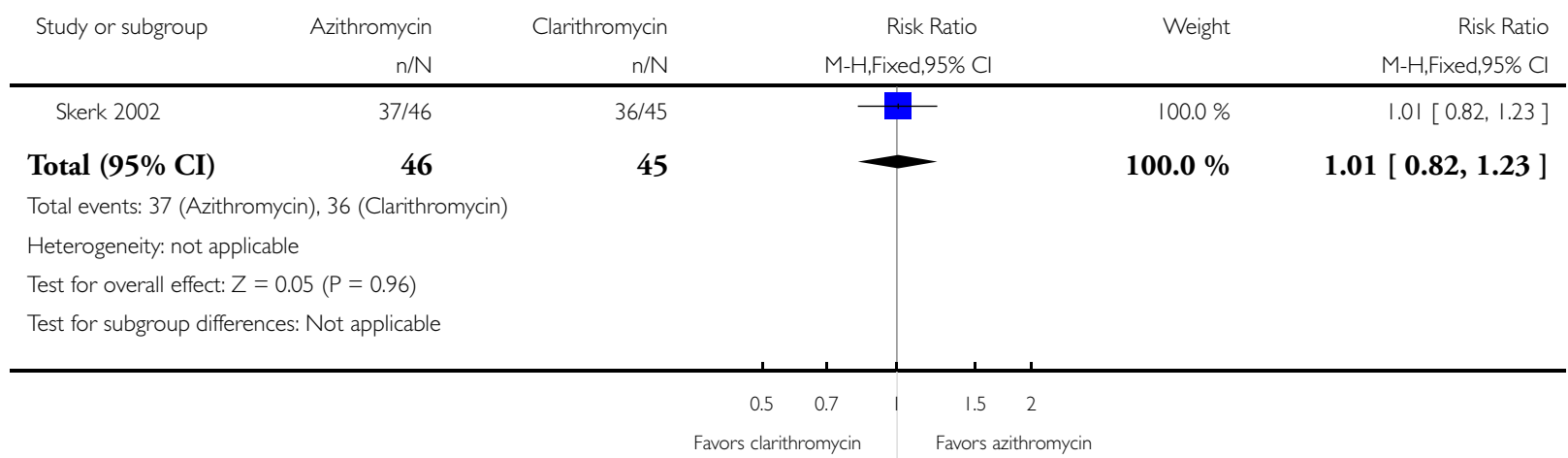

Analysis 14.2. Comparison 14 Non-fluoroquinolone antibacterial agents: azithromycin versus clarithromycin in chlamydial prostatitis, Outcome 2 Clinical efficacy (cure) at the end of treatment.

Review: Antimicrobial therapy for chronic bacterial prostatitis

Comparison: 14 Non-fluoroquinolone antibacterial agents: azithromycin versus clarithromycin in chlamydial prostatitis

Outcome: 2 Clinical efficacy (cure) at the end of treatment

$\begin{array}{llll}\text { Study or subgroup } & \text { Azithromycin } & \text { Clarithromycin } & \text { Risk Ratio Reight }\end{array}$ H,Random,95\% H, Handom,95\%

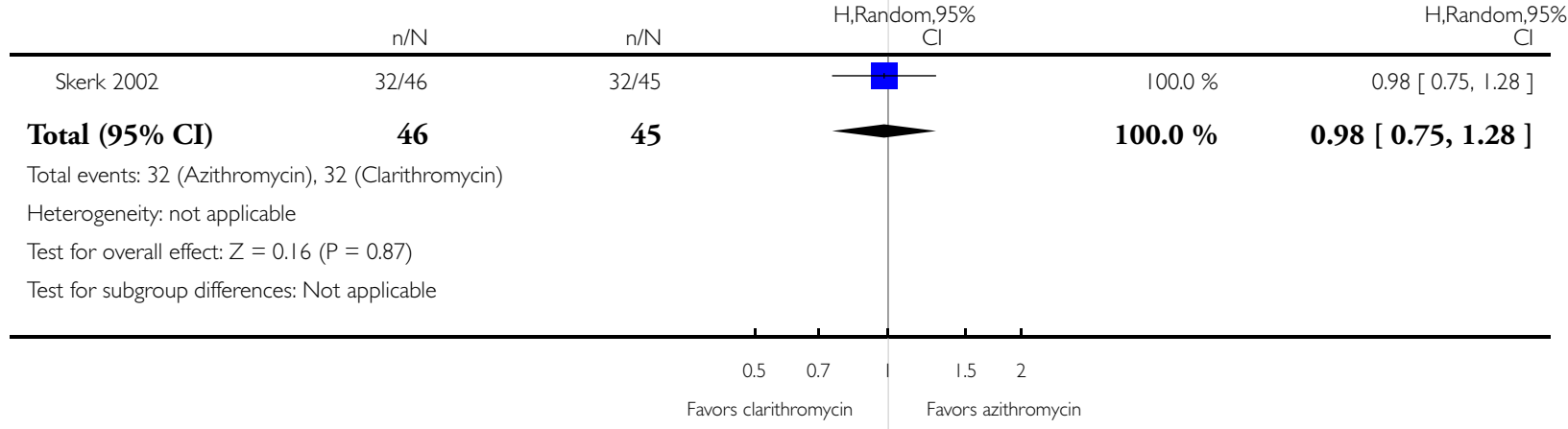


Analysis 14.3. Comparison 14 Non-fluoroquinolone antibacterial agents: azithromycin versus clarithromycin in chlamydial prostatitis, Outcome 3 Adverse effects of treatment.

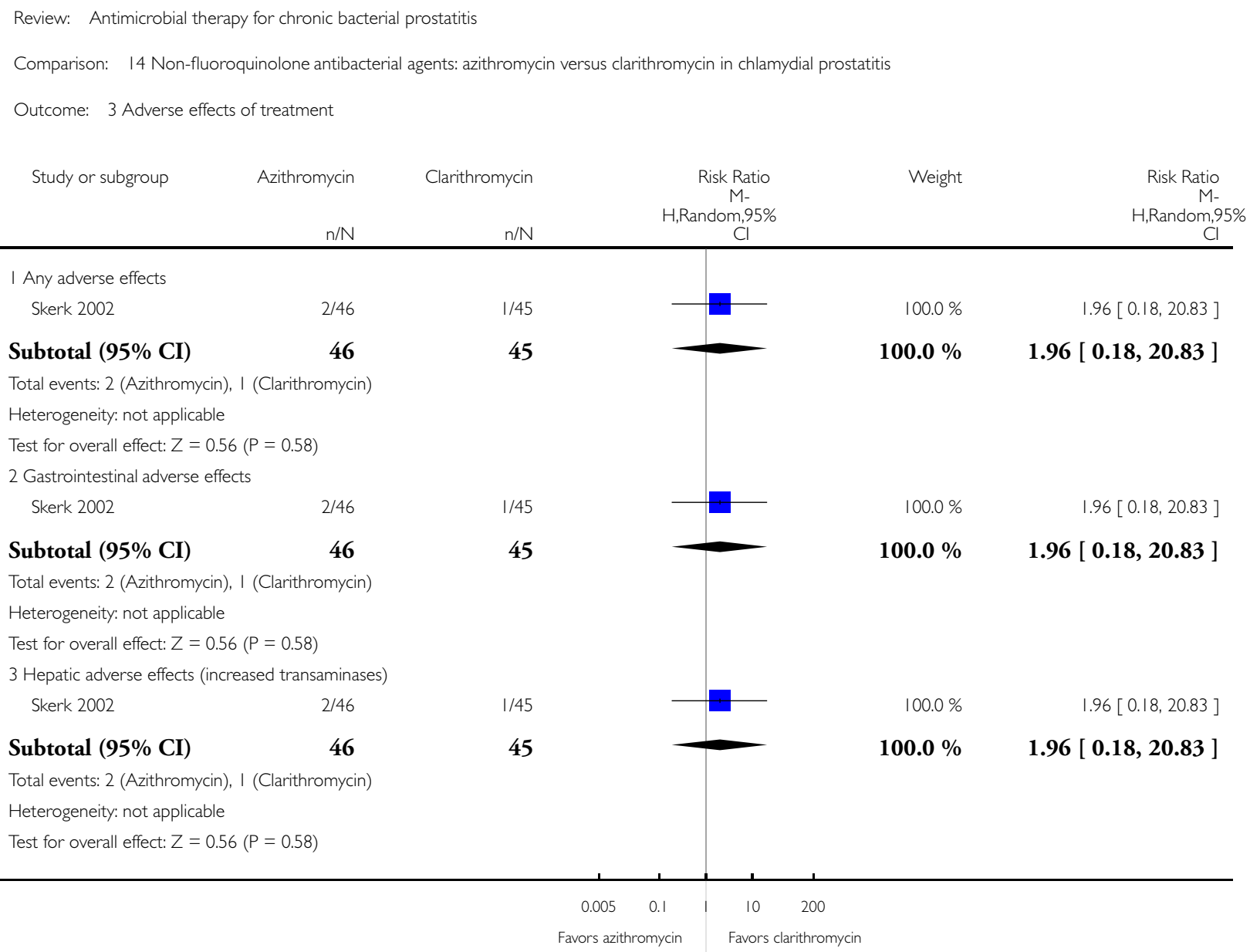


Analysis 15.I. Comparison I5 Non-fluoroquinolone antibacterial agents: azithromycin versus doxycycline in chlamydial prostatitis, Outcome I Microbiological efficacy (pathogen eradication) at the end of treatment.

Review: Antimicrobial therapy for chronic bacterial prostatitis

Comparison: 15 Non-fluoroquinolone antibacterial agents: azithromycin versus doxycycline in chlamydial prostatitis

Outcome: I Microbiological efficacy (pathogen eradication) at the end of treatment

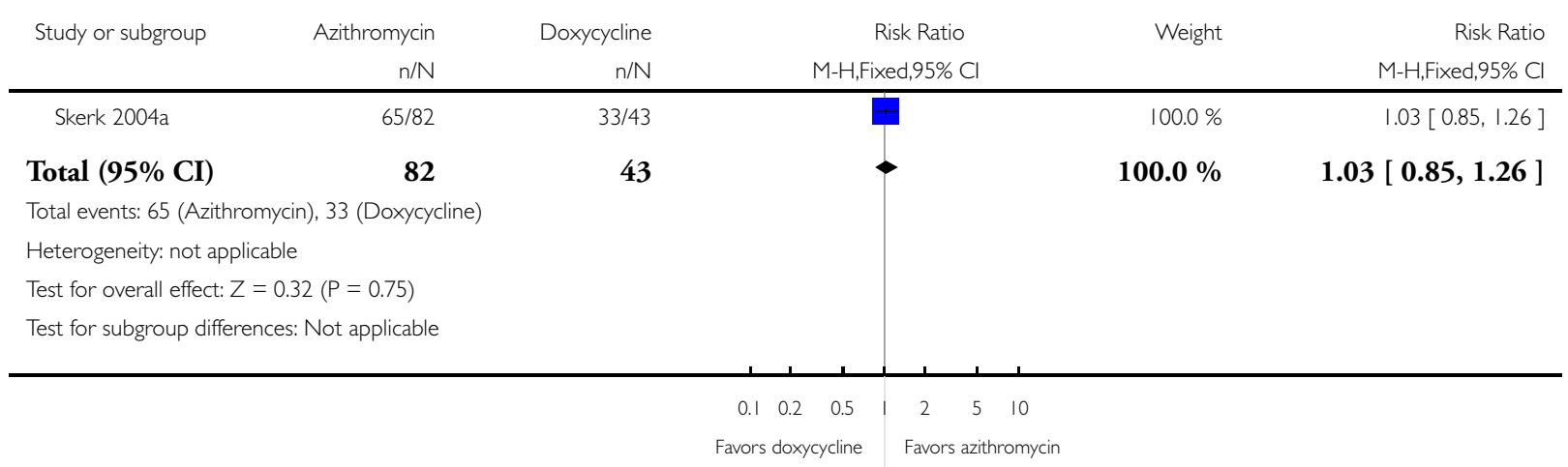


Analysis 15.2. Comparison I5 Non-fluoroquinolone antibacterial agents: azithromycin versus doxycycline in chlamydial prostatitis, Outcome 2 Clinical efficacy.

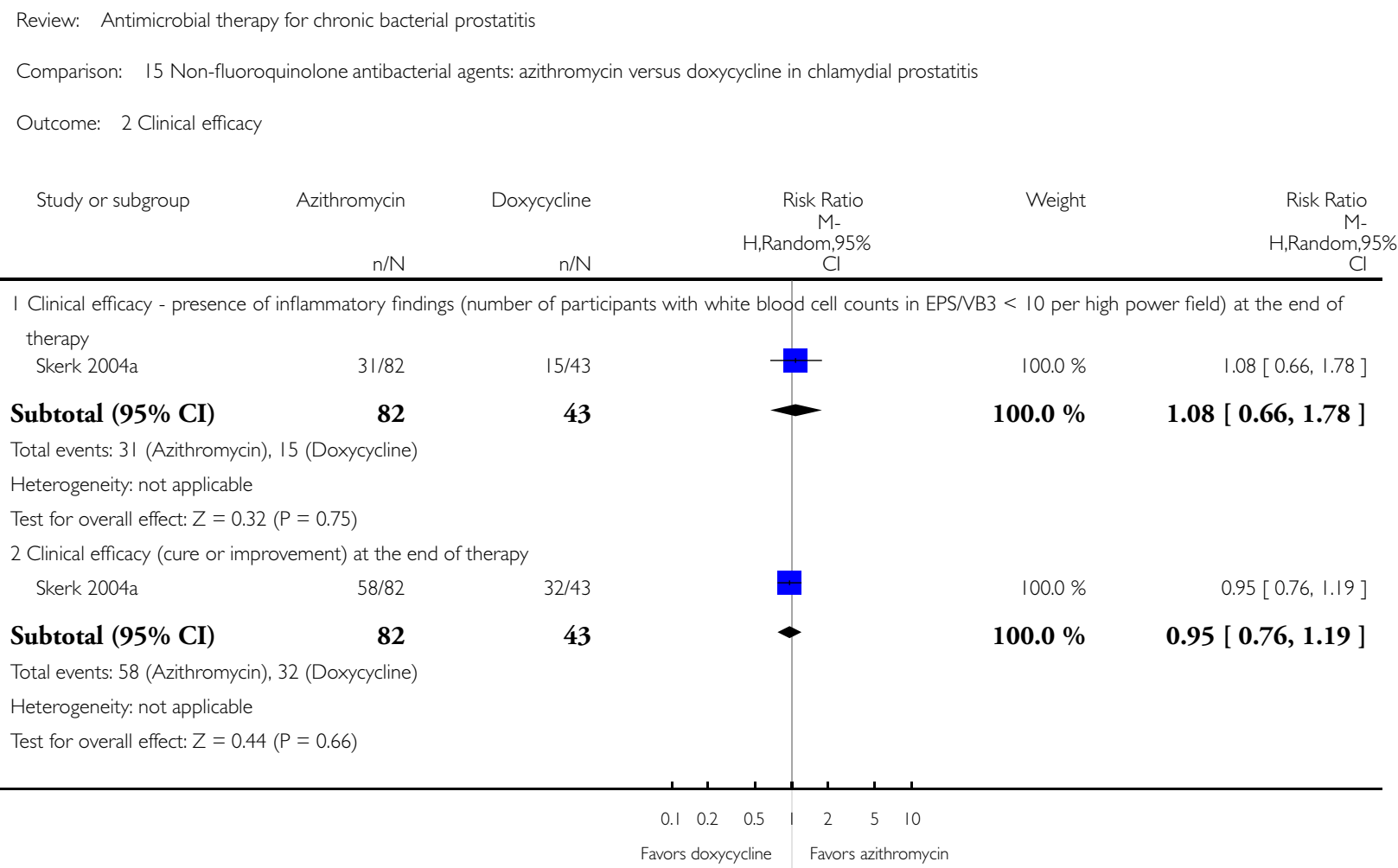


Analysis 15.3. Comparison I5 Non-fluoroquinolone antibacterial agents: azithromycin versus doxycycline in chlamydial prostatitis, Outcome 3 Adverse effects of treatment.

Review: Antimicrobial therapy for chronic bacterial prostatitis

Comparison: 15 Non-fluoroquinolone antibacterial agents: azithromycin versus doxycycline in chlamydial prostatitis

Outcome: 3 Adverse effects of treatment

$\begin{array}{llll}\text { Study or subgroup } & \text { Azithromycin } & \text { Doxycycline } & \text { Risk Ratio }\end{array}$ H,Random,95\% H,Random,95\%

$\mathrm{n} / \mathrm{N} \quad \mathrm{n} / \mathrm{N} \quad \mathrm{Cl} \quad \mathrm{Cl}$

I Any adverse effects

Skerk 2004a

$2 / 82 \quad 5 / 43$

Subtotal (95\% CI)

82

43

$100.0 \%$

$0.21[0.04,1.04]$

Total events: 2 (Azithromycin), 5 (Doxycycline)

Heterogeneity: not applicable

Test for overall effect: $Z=1.92(P=0.055)$

2 Gastrointestinal adverse effects

Skerk 2004a 2/82

Subtotal (95\% CI)

82

Total events: 2 (Azithromycin), 5 (Doxycycline)

Heterogeneity: not applicable

Test for overall effect: $Z=1.92(P=0.055)$

3 Hepatic adverse effects (increased transaminases)

Skerk 2004a

$2 / 82$

82

Subtotal (95\% CI)

Total events: 2 (Azithromycin), 0 (Doxycycline)

Heterogeneity: not applicable

Test for overall effect: $Z=0.63(P=0.53)$

5/43

$5 / 43$

43

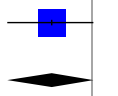

$100.0 \%$

$0.21[0.04,1.04]$

$100.0 \%$

$0.21[0.04,1.04$ ]

$100.0 \%$

$2.65[0.13,54.00]$

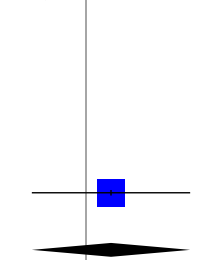

43

$100.0 \%$

$2.65[0.13,54.00]$ 
Analysis 16.1. Comparison 16 Non-fluoroquinolone antibacterial agents: azithromycin versus doxycycline in ureaplasmal prostatitis, Outcome I Microbiological efficacy (pathogen eradication) at the end of treatment.

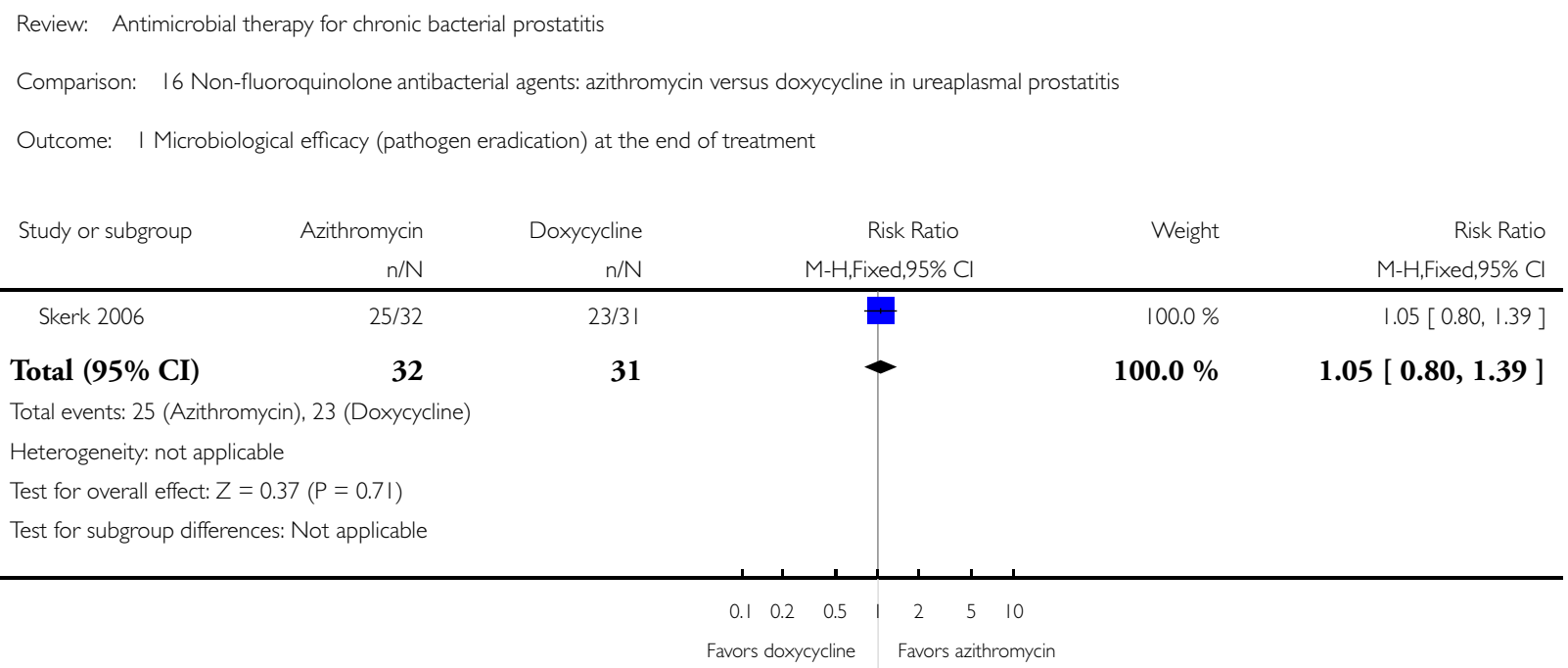

Analysis 16.2. Comparison 16 Non-fluoroquinolone antibacterial agents: azithromycin versus doxycycline in ureaplasmal prostatitis, Outcome 2 Clinical efficacy (cure) at the end of treatment.

Review: Antimicrobial therapy for chronic bacterial prostatitis

Comparison: 16 Non-fluoroquinolone antibacterial agents: azithromycin versus doxycycline in ureaplasmal prostatitis

Outcome: 2 Clinical efficacy (cure) at the end of treatment

$\begin{array}{llll}\text { Study or subgroup } & \text { Azithromycin Risk Ratio Doxycycline } \quad \text { Weight }\end{array}$

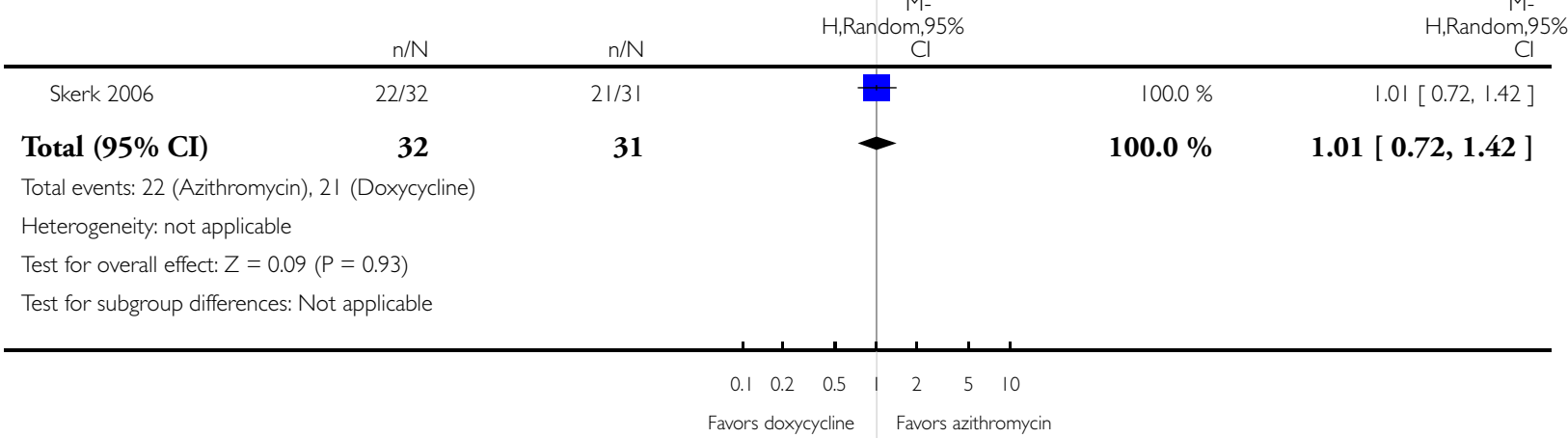


Analysis 16.3. Comparison 16 Non-fluoroquinolone antibacterial agents: azithromycin versus doxycycline in ureaplasmal prostatitis, Outcome 3 Adverse effects of treatment.

Review: Antimicrobial therapy for chronic bacterial prostatitis

Comparison: 16 Non-fluoroquinolone antibacterial agents: azithromycin versus doxycycline in ureaplasmal prostatitis

Outcome: 3 Adverse effects of treatment

Study or subgroup

Azithromycin

Doxycycline

Risk Ratio

M-

H,Random, $95 \%$

$\mathrm{n} / \mathrm{N}$

$n / N$

I Any adverse effects

Skerk 2006

$0 / 32$

32

Subtotal (95\% CI)

Total events: 0 (Azithromycin), 5 (Doxycycline)

Heterogeneity: not applicable

Test for overall effect: $Z=1.67(P=0.095)$

2 Gastrointestinal adverse effects

Skerk 2006

Subtotal (95\% CI)

32

Total events: 0 (Azithromycin), 5 (Doxycycline)

Heterogeneity: not applicable

Test for overall effect: $Z=1.67(P=0.095)$

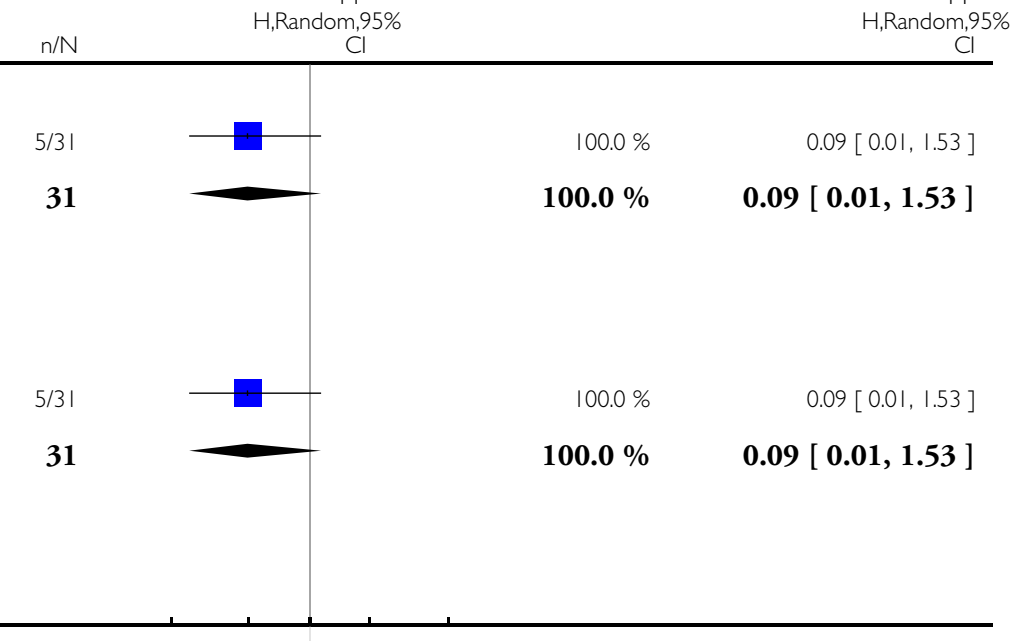

$\begin{array}{cccc}0.005 & 0.1 & 10 & 200 \\ \text { Favors azithromycin } & \text { Favors doxycycline }\end{array}$ 
Analysis 17.I. Comparison 17 Different dosing regimens: azithromycin $4.5 \mathrm{~g}$ versus $6.0 \mathrm{~g}$ total doses in chlamydial prostatitis, Outcome I Microbiological efficacy (pathogen eradication) at the end of treatment.

Review: Antimicrobial therapy for chronic bacterial prostatitis

Comparison: 17 Different dosing regimens: azithromycin $4.5 \mathrm{~g}$ versus $6.0 \mathrm{~g}$ total doses in chlamydial prostatitis

Outcome: I Microbiological efficacy (pathogen eradication) at the end of treatment

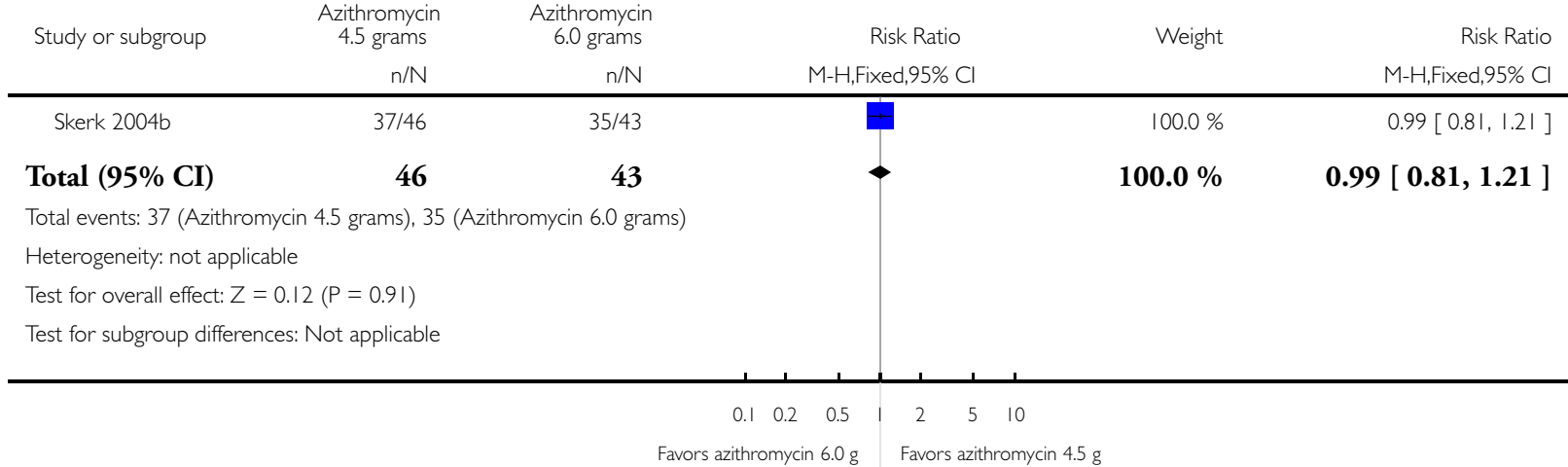

Analysis 17.2. Comparison 17 Different dosing regimens: azithromycin $4.5 \mathrm{~g}$ versus $6.0 \mathrm{~g}$ total doses in chlamydial prostatitis, Outcome 2 Clinical efficacy (cure) at the end of therapy.

Review: Antimicrobial therapy for chronic bacterial prostatitis

Comparison: 17 Different dosing regimens: azithromycin $4.5 \mathrm{~g}$ versus $6.0 \mathrm{~g}$ total doses in chlamydial prostatitis

Outcome: 2 Clinical efficacy (cure) at the end of therapy

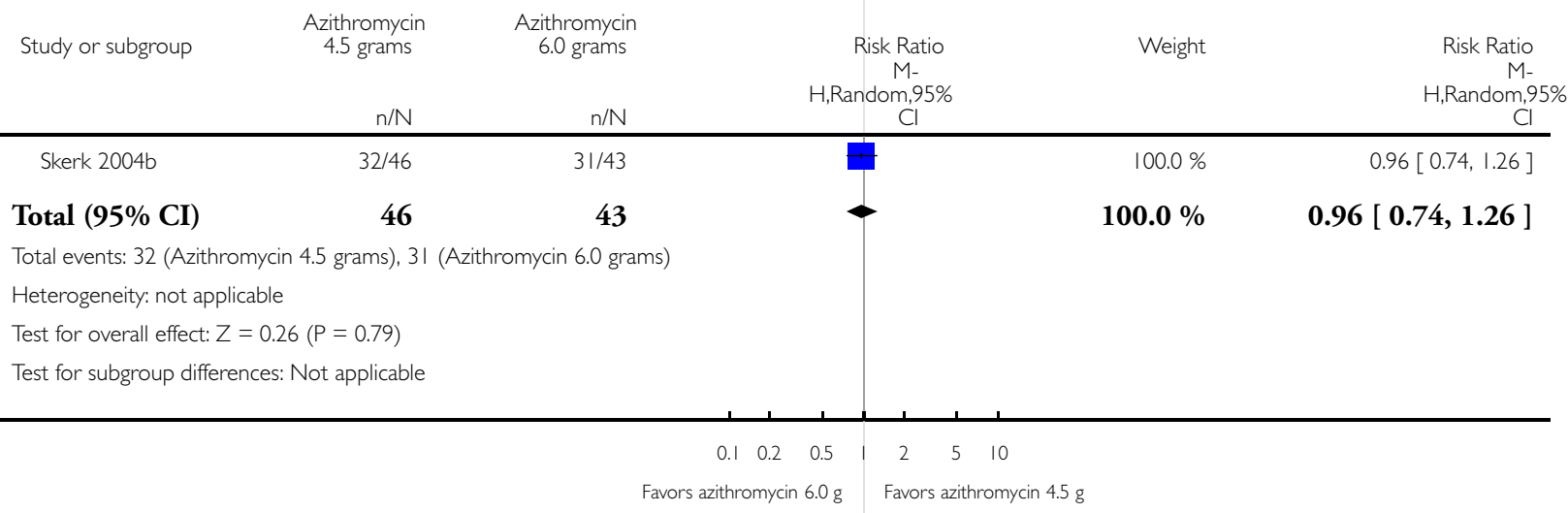

Antimicrobial therapy for chronic bacterial prostatitis (Review)

Copyright @ 2013 The Cochrane Collaboration. Published by John Wiley \& Sons, Ltd. 


\section{Analysis 17.3. Comparison I7 Different dosing regimens: azithromycin $4.5 \mathrm{~g}$ versus $6.0 \mathrm{~g}$ total doses in} chlamydial prostatitis, Outcome 3 Adverse effects of treatment.

Review: Antimicrobial therapy for chronic bacterial prostatitis

Comparison: 17 Different dosing regimens: azithromycin $4.5 \mathrm{~g}$ versus $6.0 \mathrm{~g}$ total doses in chlamydial prostatitis

Outcome: 3 Adverse effects of treatment

\begin{tabular}{|c|c|c|c|c|c|}
\hline Study or subgroup & $\begin{array}{c}\text { Azithromycin } \\
4.5 \text { grams } \\
\mathrm{n} / \mathrm{N}\end{array}$ & $\begin{array}{c}\text { Azithromycin } \\
6.0 \text { grams } \\
n / N\end{array}$ & $\begin{array}{r}\text { Risk Ratio } \\
\text { M- } \\
\text { H,Random,95\% } \\
\text { Cl }\end{array}$ & Weight & $\begin{array}{c}\text { Risk Ratio } \\
\text { M- } \\
\text { H,Random,959 }\end{array}$ \\
\hline
\end{tabular}

\footnotetext{
I Any adverse effects

Skerk 2004b
}

$0 / 46$

$2 / 43$

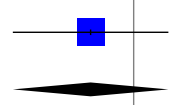

$100.0 \%$

$0.19[0.01,3.79]$

Subtotal (95\% CI)

46

43

Total events: 0 (Azithromycin 4.5 grams), 2 (Azithromycin 6.0 grams)

Heterogeneity: not applicable

Test for overall effect: $Z=1.09(P=0.28)$

2 Hepatic adverse effects (increased transaminases)

Skerk 2004b 0/46

$2 / 43$

46

43

Subtotal (95\% CI)

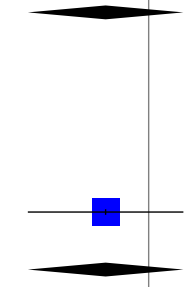

$100.0 \%$

$0.19[0.01,3.79$ ]

Total events: 0 (Azithromycin 4.5 grams), 2 (Azithromycin 6.0 grams)

Heterogeneity: not applicable

Test for overall effect: $Z=1.09(P=0.28)$

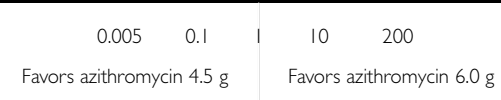


Analysis 18.I. Comparison I8 Different therapy duration: co-trimoxazole $480 \mathrm{mg}$ twice daily for 12 weeks versus 10 days, Outcome I Microbiological efficacy (pathogen eradication) at the end of treatment.

Review: Antimicrobial therapy for chronic bacterial prostatitis

Comparison: 18 Different therapy duration: co-trimoxazole $480 \mathrm{mg}$ twice daily for 12 weeks versus 10 days

Outcome: I Microbiological efficacy (pathogen eradication) at the end of treatment

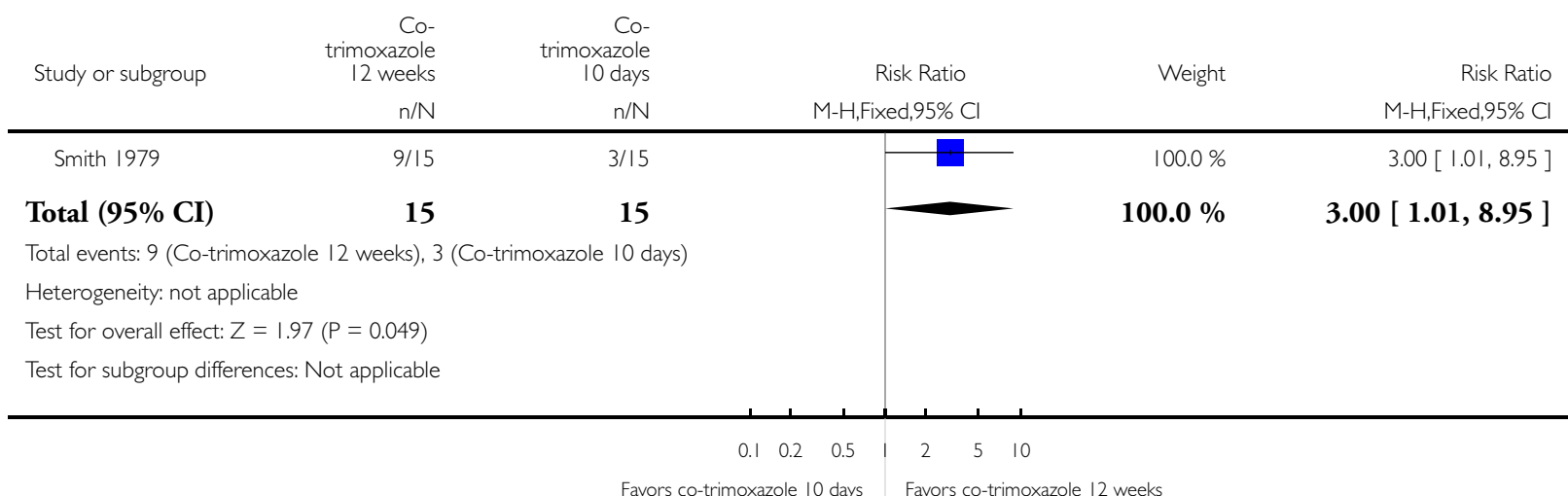


Analysis 18.2. Comparison 18 Different therapy duration: co-trimoxazole $480 \mathrm{mg}$ twice daily for 12 weeks versus 10 days, Outcome 2 Adverse effects of treatment.

Review: Antimicrobial therapy for chronic bacterial prostatitis

Comparison: 18 Different therapy duration: co-trimoxazole $480 \mathrm{mg}$ twice daily for 12 weeks versus 10 days

Outcome: 2 Adverse effects of treatment

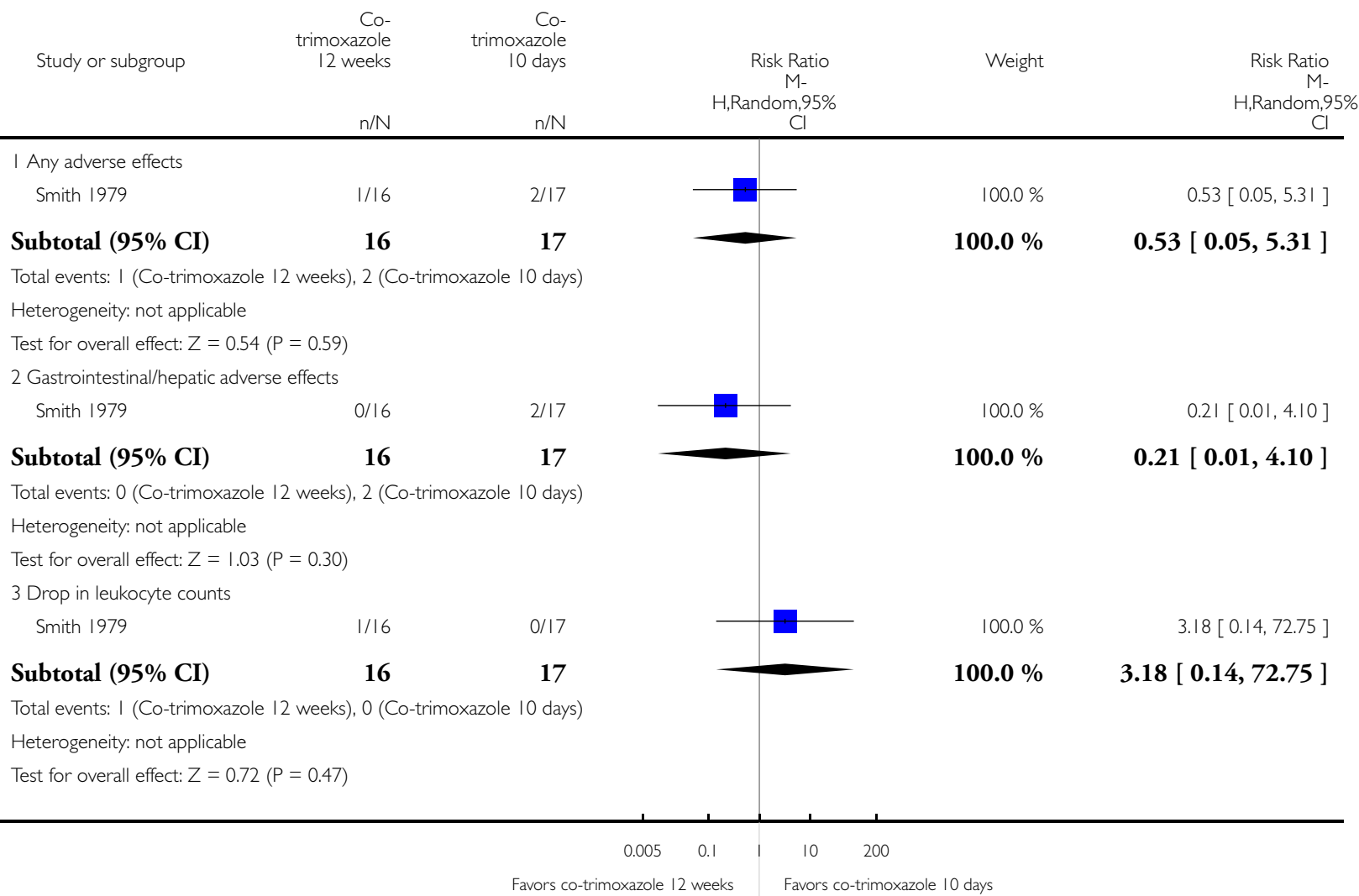


Analysis 19.1. Comparison 19 Fluoroquinolone combined with phosphodiesterase-5 inhibitor versus fluoroquinolone: levofloxacin plus vardenafil $10 \mathrm{mg} /$ day versus levofloxacin, Outcome I Microbiological efficacy (pathogen eradication) at the end of treatment.

Review: Antimicrobial therapy for chronic bacterial prostatitis

Comparison: 19 Fluoroquinolone combined with phosphodiesterase-5 inhibitor versus fluoroquinolone: levofloxacin plus vardenafil 10 mg/day versus levofloxacin

Outcome: I Microbiological efficacy (pathogen eradication) at the end of treatment

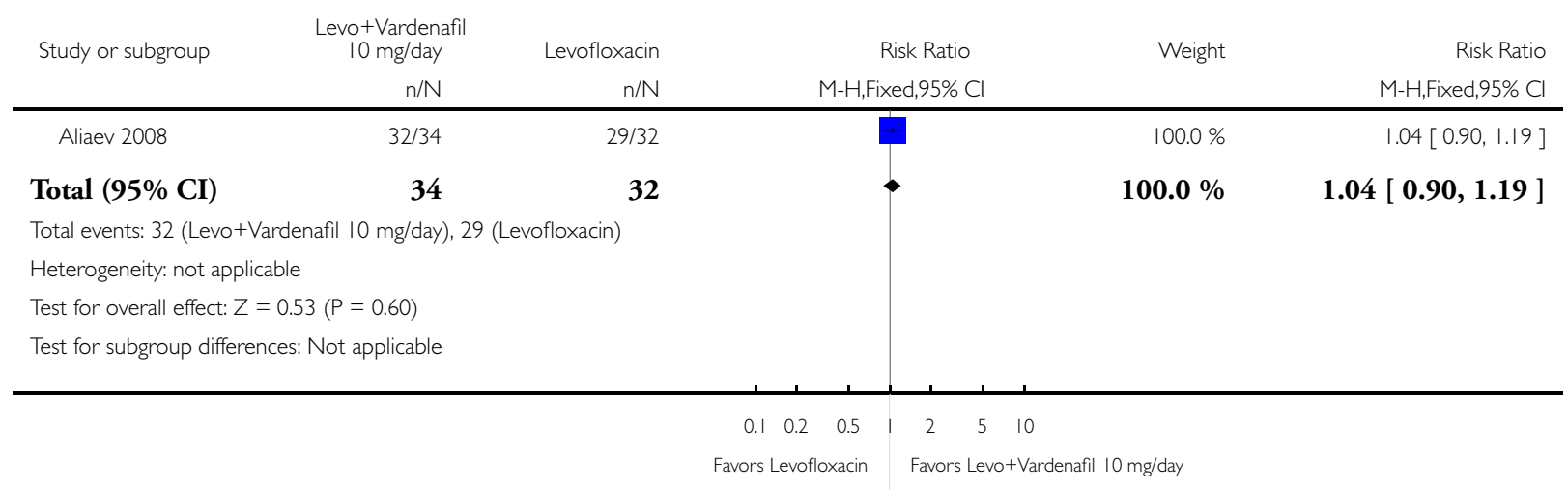


Analysis 19.2. Comparison 19 Fluoroquinolone combined with phosphodiesterase-5 inhibitor versus fluoroquinolone: levofloxacin plus vardenafil $10 \mathrm{mg} /$ day versus levofloxacin, Outcome 2 Clinical efficacy - NIHCPSI score at the end of treatment.

Review: Antimicrobial therapy for chronic bacterial prostatitis

Comparison: 19 Fluoroquinolone combined with phosphodiesterase-5 inhibitor versus fluoroquinolone: levofloxacin plus vardenafil 10 mg/day versus levofloxacin

Outcome: 2 Clinical efficacy - NIH-CPSI score at the end of treatment

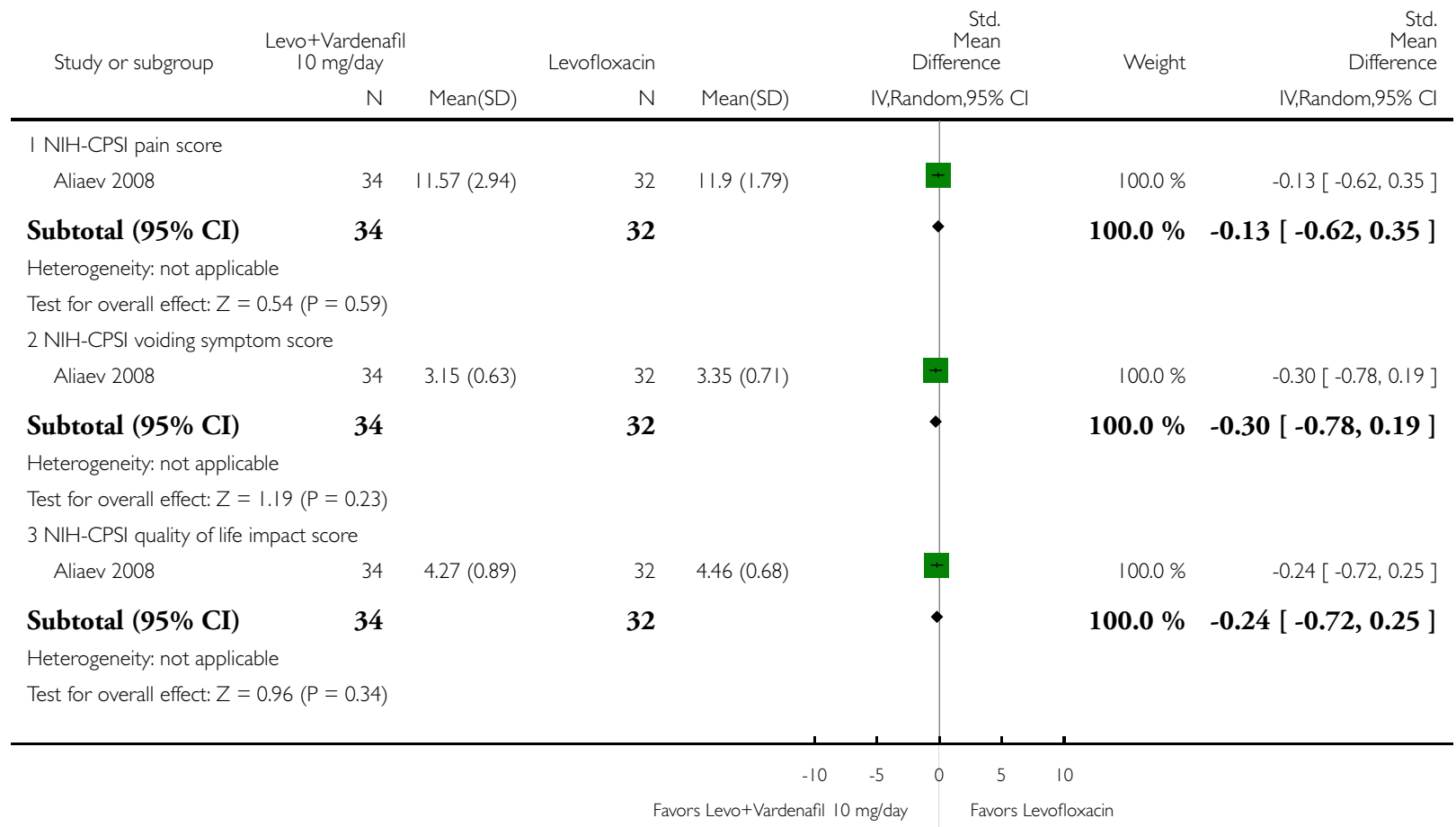


Analysis 19.3. Comparison 19 Fluoroquinolone combined with phosphodiesterase-5 inhibitor versus fluoroquinolone: levofloxacin plus vardenafil $10 \mathrm{mg} /$ day versus levofloxacin, Outcome 3 Clinical efficacy number of participants with leukocytosis in post-massage urine specimens at the end of treatment.

Review: Antimicrobial therapy for chronic bacterial prostatitis

Comparison: 19 Fluoroquinolone combined with phosphodiesterase-5 inhibitor versus fluoroquinolone: levofloxacin plus vardenafil 10 mg/day versus levofloxacin

Outcome: 3 Clinical efficacy - number of participants with leukocytosis in post-massage urine specimens at the end of treatment

\begin{tabular}{|c|c|c|c|c|c|}
\hline Study or subgroup & $\begin{array}{c}\text { Levo+Vardenafil } \\
10 \mathrm{mg} / \text { day } \\
\mathrm{n} / \mathrm{N}\end{array}$ & Levofloxacin & $\begin{array}{c}\text { Risk Ratio } \\
\text { M- } \\
\text { H,Random,95\% } \\
\text { Cl }\end{array}$ & Weight & $\begin{array}{c}\text { Risk Ratio } \\
\text { M- } \\
\text { H,Random,95\% } \\
\text { Cl }\end{array}$ \\
\hline Aliaev 2008 & $4 / 34$ & $7 / 32$ & 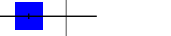 & $100.0 \%$ & $0.54[0.17,1.66]$ \\
\hline
\end{tabular}

Total $(95 \% \mathrm{CI})$

34

32

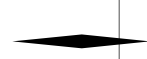

$100.0 \%$

$0.54[0.17,1.66$ ]

Total events: 4 (Levo+Vardenafil 10 mg/day), 7 (Levofloxacin)

Heterogeneity: not applicable

Test for overall effect: $Z=1.08(P=0.28)$

Test for subgroup differences: Not applicable

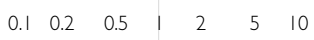

Favors Levo+Vardenafil $10 \mathrm{mg} /$ day $\quad$ Favors Levofloxacin

Analysis 19.4. Comparison 19 Fluoroquinolone combined with phosphodiesterase-5 inhibitor versus fluoroquinolone: levofloxacin plus vardenafil $10 \mathrm{mg} /$ day versus levofloxacin, Outcome 4 Clinical efficacy - urine peak flow rate at the end of treatment $(\mathrm{mL} / \mathrm{s})$.

Review: Antimicrobial therapy for chronic bacterial prostatitis

Comparison: 19 Fluoroquinolone combined with phosphodiesterase-5 inhibitor versus fluoroquinolone: levofloxacin plus vardenafil 10 mg/day versus levofloxacin

Outcome: 4 Clinical efficacy - urine peak flow rate at the end of treatment $(\mathrm{mL} / \mathrm{s})$

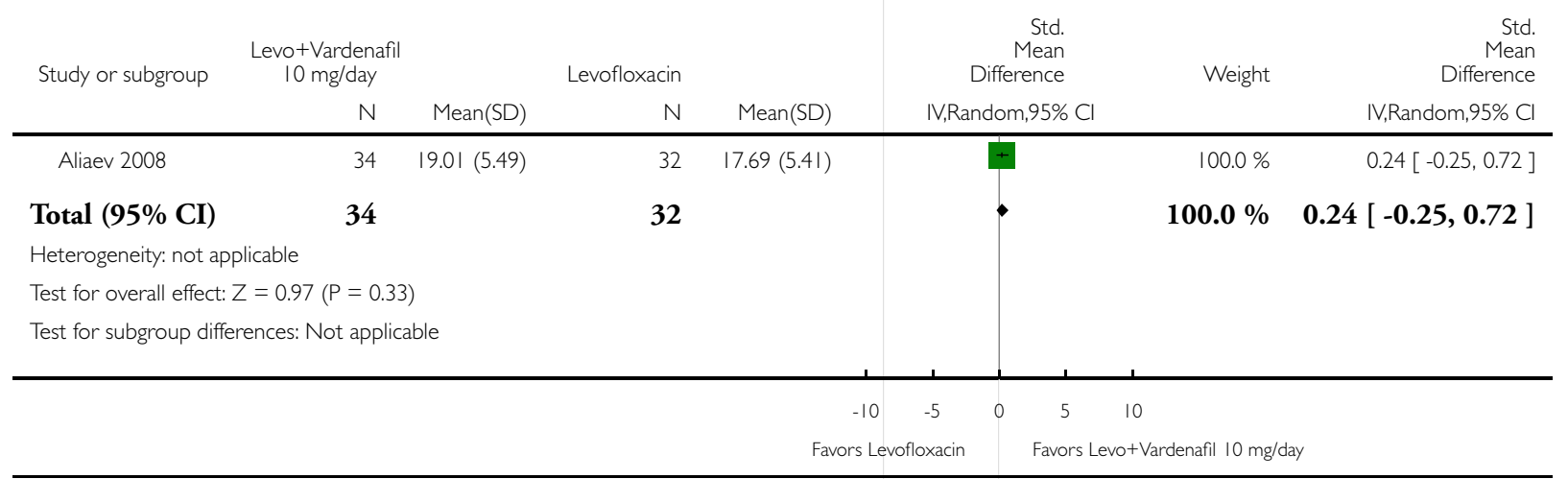

Antimicrobial therapy for chronic bacterial prostatitis (Review)

Copyright @ 2013 The Cochrane Collaboration. Published by John Wiley \& Sons, Ltd. 
Analysis 20.1. Comparison 20 Fluoroquinolone combined with phosphodiesterase-5 inhibitor versus fluoroquinolone: levofloxacin plus vardenafil $10 \mathrm{mg}$ on-demand versus levofloxacin, Outcome I Microbiological efficacy (pathogen eradication) at the end of treatment.

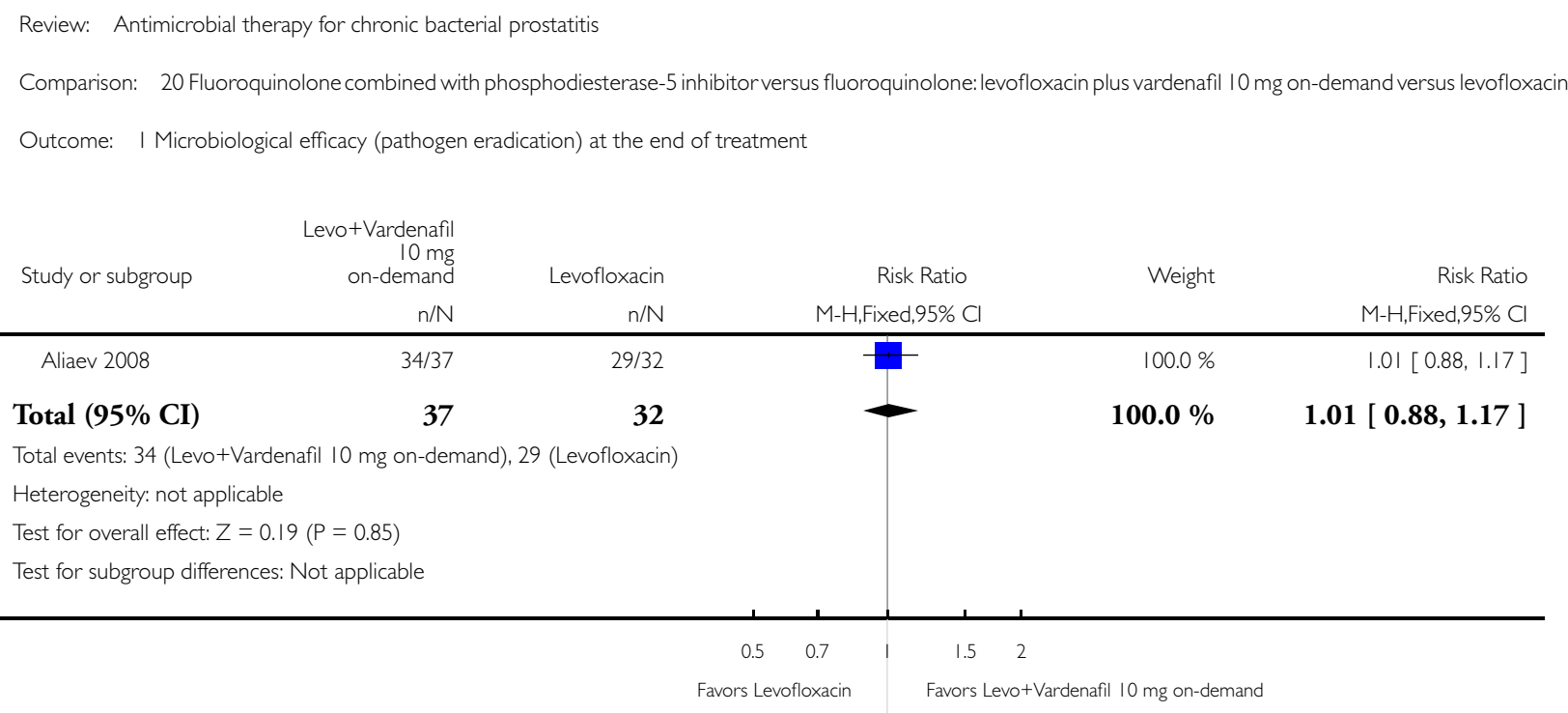


Analysis 20.2. Comparison 20 Fluoroquinolone combined with phosphodiesterase-5 inhibitor versus fluoroquinolone: levofloxacin plus vardenafil $10 \mathrm{mg}$ on-demand versus levofloxacin, Outcome 2 Clinical efficacy - NIH-CPSI score at the end of treatment.

Review: Antimicrobial therapy for chronic bacterial prostatitis

Comparison: 20 Fluoroquinolone combined with phosphodiesterase- 5 inhibitorversus fluoroquinolone: levofloxacin plus vardenafil 10 mg on-demand versus levofloxacin

Outcome: 2 Clinical efficacy - NIH-CPSI score at the end of treatment

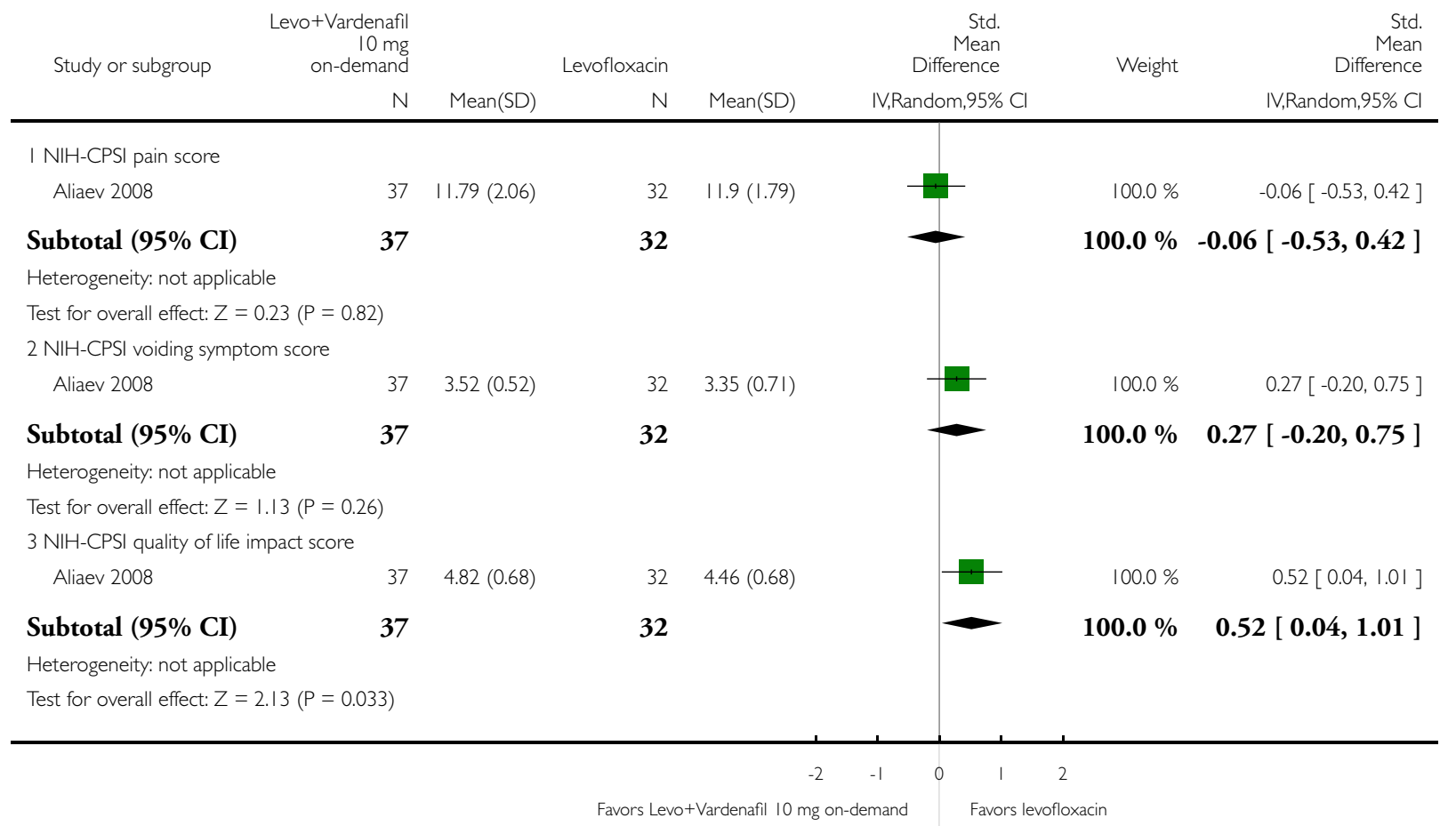


Analysis 20.3. Comparison 20 Fluoroquinolone combined with phosphodiesterase-5 inhibitor versus fluoroquinolone: levofloxacin plus vardenafil $10 \mathrm{mg}$ on-demand versus levofloxacin, Outcome $3 \mathrm{Clinical}$ efficacy - number of participants with leukocytosis in post-massage urine specimens at the end of treatment.

Review: Antimicrobial therapy for chronic bacterial prostatitis

Comparison: 20 Fluoroquinolone combined with phosphodiesterase-5 inhibitorversus fluoroquinolone: levofloxacin plus vardenafil 10 mg on-demand versus levofloxacin

Outcome: 3 Clinical efficacy - number of participants with leukocytosis in post-massage urine specimens at the end of treatment

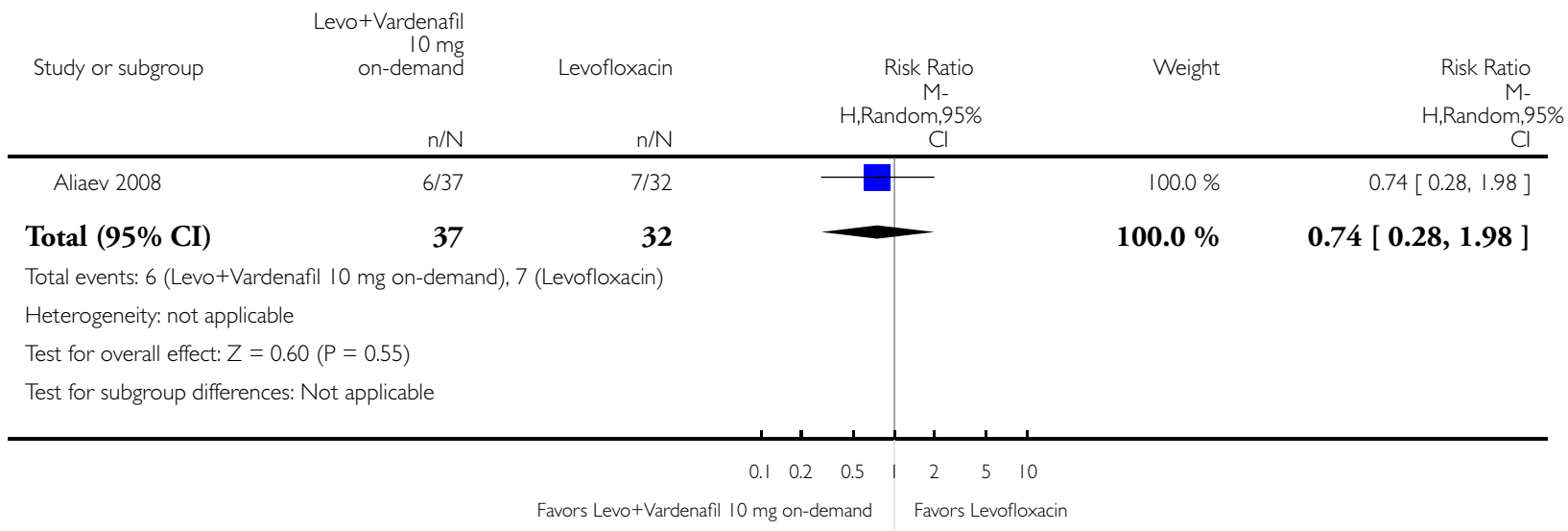


Analysis 20.4. Comparison 20 Fluoroquinolone combined with phosphodiesterase-5 inhibitor versus fluoroquinolone: levofloxacin plus vardenafil $10 \mathrm{mg}$ on-demand versus levofloxacin, Outcome $4 \mathrm{Clinical}$ efficacy - urine peak flow rate at the end of treatment $(\mathrm{mL} / \mathrm{s})$.

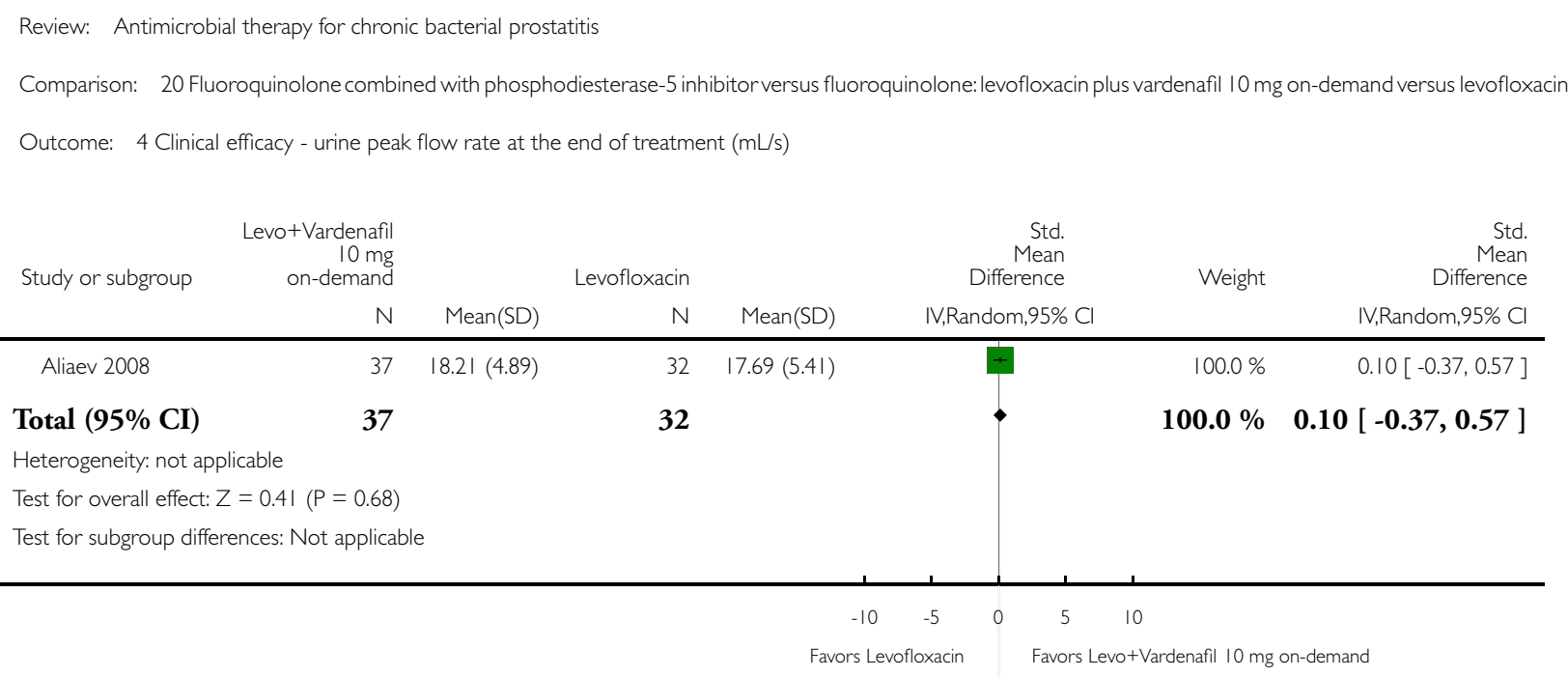


Analysis 2I.I. Comparison 2 I Fluoroquinolone combined with phosphodiesterase-5 inhibitor: levofloxacin plus vardenafil $10 \mathrm{mg} /$ day versus levofloxacin plus vardenafil $10 \mathrm{mg}$ on-demand, Outcome I Microbiological efficacy (pathogen eradication) at the end of treatment.

Review: Antimicrobial therapy for chronic bacterial prostatitis

Comparison: 21 Fluoroquinolone combined with phosphodiesterase-5 inhibitor: levofloxacin plus vardenafil 10 mg/day versus levofloxacin plus vardenafil 10 mg ondemand

Outcome: I Microbiological efficacy (pathogen eradication) at the end of treatment

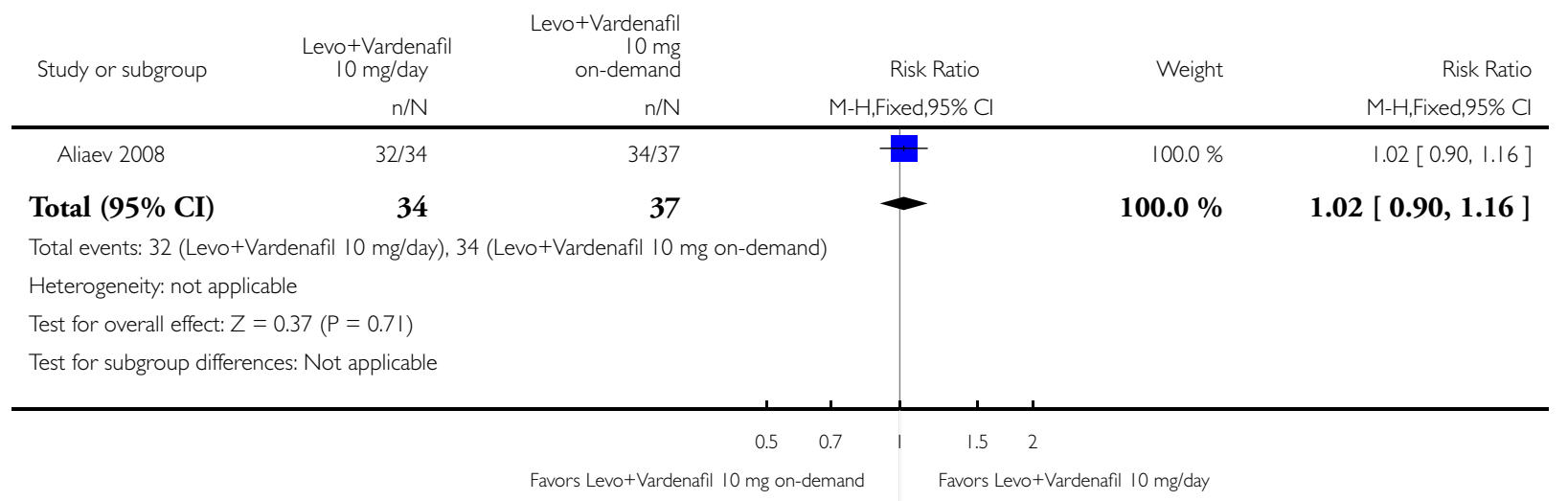


Analysis 21.2. Comparison 21 Fluoroquinolone combined with phosphodiesterase-5 inhibitor: levofloxacin plus vardenafil $10 \mathrm{mg} /$ day versus levofloxacin plus vardenafil $10 \mathrm{mg}$ on-demand, Outcome 2 Clinical efficacy NIH-CPSI score at the end of treatment.

Review: Antimicrobial therapy for chronic bacterial prostatitis

Comparison: 21 Fluoroquinolone combined with phosphodiesterase-5 inhibitor: levofloxacin plus vardenafil 10 mg/day versus levofloxacin plus vardenafil 10 mg ondemand

Outcome: 2 Clinical efficacy - NIH-CPSI score at the end of treatment

\begin{tabular}{|c|c|c|c|c|c|c|c|}
\hline \multirow[t]{2}{*}{ Study or subgroup } & \multicolumn{2}{|c|}{$\begin{array}{l}\text { Levo+Vardenafil } \\
10 \mathrm{mg} / \text { day }\end{array}$} & $\begin{array}{r}\text { Levo+Vardenafil } \\
10 \mathrm{mg} \\
\text { on-demand }\end{array}$ & \multirow[b]{2}{*}{ Mean(SD) } & $\begin{array}{r}\text { Std. } \\
\text { Mean } \\
\text { Difference }\end{array}$ & \multirow[t]{2}{*}{ Weight } & \multirow{2}{*}{$\begin{array}{r}\text { Std. } \\
\text { Mean } \\
\text { Difference } \\
\text { IV,Random,95\% Cl }\end{array}$} \\
\hline & $N$ & Mean(SD) & N & & IV,Random,95\% Cl & & \\
\hline \multicolumn{8}{|l|}{ I NIH-CPSI pain score } \\
\hline Aliaev 2008 & 34 & I $1.57(2.94)$ & 37 & $11.79(2.06)$ & & $100.0 \%$ & $-0.09[-0.55,0.38]$ \\
\hline Subtotal (95\% CI) & 34 & & 37 & & & $100.0 \%$ & $-0.09[-0.55,0.38]$ \\
\hline \multicolumn{8}{|c|}{ Heterogeneity: not applicable } \\
\hline \multicolumn{8}{|c|}{ Test for overall effect: $Z=0.36(P=0.72)$} \\
\hline \multicolumn{8}{|c|}{$2 \mathrm{NIH}-\mathrm{CPSI}$ voiding symptom score } \\
\hline Aliaev 2008 & 34 & $3.15(0.63)$ & 37 & $3.52(0.52)$ & & $100.0 \%$ & $-0.64[-1.11,-0.16]$ \\
\hline Subtotal (95\% CI) & 34 & & 37 & & & $100.0 \%$ & $-0.64[-1.11,-0.16]$ \\
\hline \multicolumn{8}{|c|}{ Heterogeneity: not applicable } \\
\hline \multicolumn{8}{|c|}{ Test for overall effect: $Z=2.61(P=0.009 \mid)$} \\
\hline \multicolumn{8}{|c|}{$3 \mathrm{NIH}-\mathrm{CPSI}$ quality of life impact score } \\
\hline Aliaev 2008 & 34 & $4.27(0.89)$ & 37 & $4.82(0.68)$ & & $100.0 \%$ & $-0.69[-1.17,-0.21]$ \\
\hline Subtotal (95\% CI) & 34 & & 37 & & & $100.0 \%$ & $-0.69[-1.17,-0.21]$ \\
\hline \multicolumn{8}{|c|}{ Heterogeneity: not applicable } \\
\hline \multicolumn{8}{|c|}{ Test for overall effect: $Z=2.82(P=0.0048)$} \\
\hline & & & & -2 & 1 & 2 & \\
\hline & & & & rs Levo+Vardenafil & Favors L & $0+$ Vardenafil $10 \mathrm{~m}$ & g on-demand \\
\hline
\end{tabular}


Analysis 21.3. Comparison 21 Fluoroquinolone combined with phosphodiesterase-5 inhibitor: levofloxacin plus vardenafil $10 \mathrm{mg} /$ day versus levofloxacin plus vardenafil $10 \mathrm{mg}$ on-demand, Outcome $3 \mathrm{Clinical}$ efficacy number of participants with leukocytosis in post-massage urine specimens at the end of treatment.

Review: Antimicrobial therapy for chronic bacterial prostatitis

Comparison: 21 Fluoroquinolone combined with phosphodiesterase-5 inhibitor: levofloxacin plus vardenafil 10 mg/day versus levofloxacin plus vardenafil 10 mg ondemand

Outcome: 3 Clinical efficacy - number of participants with leukocytosis in post-massage urine specimens at the end of treatment

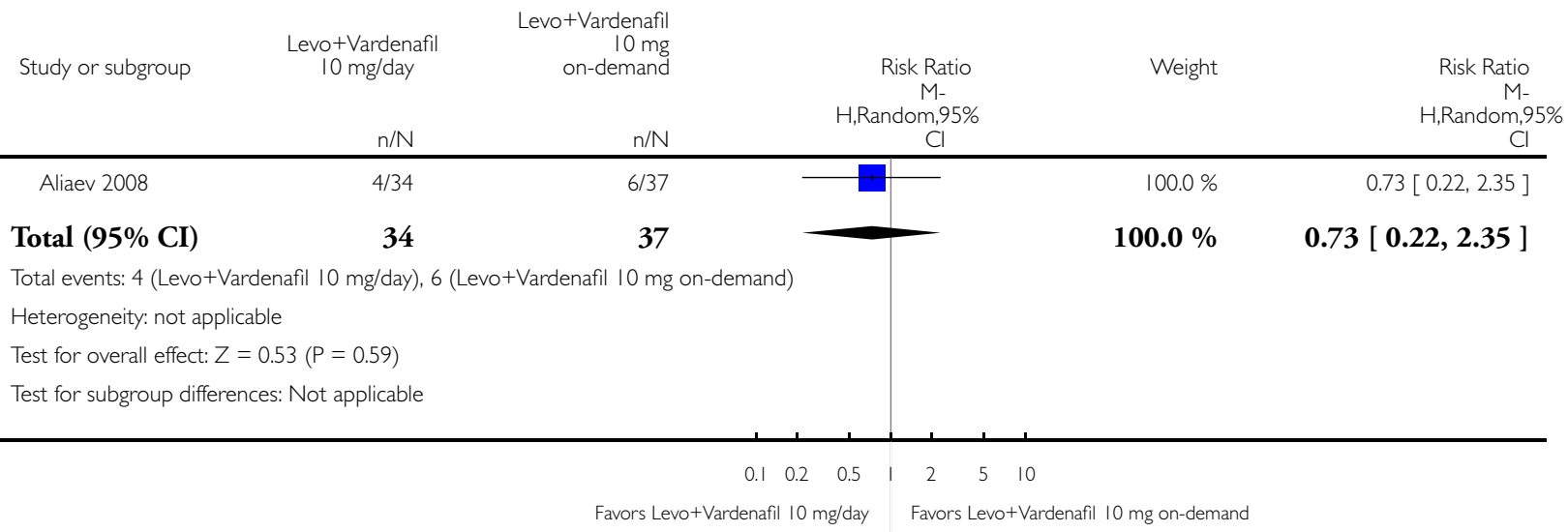


Analysis 21.4. Comparison 21 Fluoroquinolone combined with phosphodiesterase-5 inhibitor: levofloxacin plus vardenafil $10 \mathrm{mg} /$ day versus levofloxacin plus vardenafil $10 \mathrm{mg}$ on-demand, Outcome 4 Clinical efficacy urine peak flow rate at the end of treatment $(\mathrm{mL} / \mathrm{s})$.

Review: Antimicrobial therapy for chronic bacterial prostatitis

Comparison: 21 Fluoroquinolone combined with phosphodiesterase- 5 inhibitor: levofloxacin plus vardenafil 10 mg/day versus levofloxacin plus vardenafil 10 mg ondemand

Outcome: 4 Clinical efficacy - urine peak flow rate at the end of treatment $(\mathrm{mL} / \mathrm{s})$

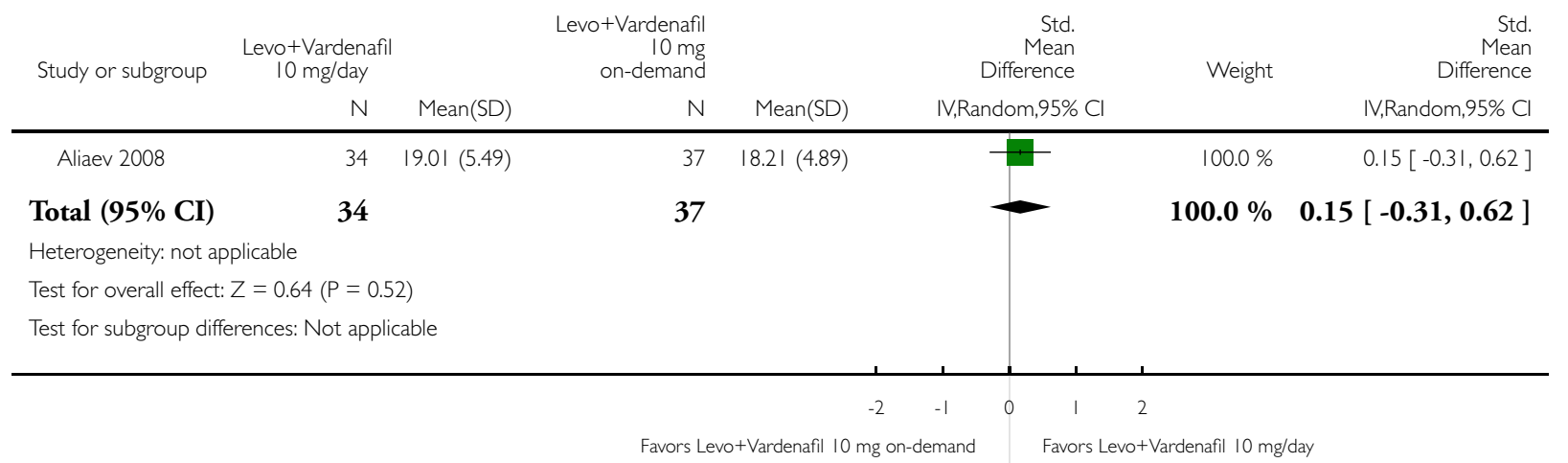


Analysis 22.1. Comparison 22 Fluoroquinolone plus herbal extracts or supplements versus fluoroquinolone: prulifloxacin plus supplements versus prulifloxacin, Outcome I Clinical efficacy - NIH-CPSI total score.

Review: Antimicrobial therapy for chronic bacterial prostatitis

Comparison: 22 Fluoroquinolone plus herbal extracts or supplements versus fluoroquinolone: prulifloxacin plus supplements versus prulifloxacin

Outcome: I Clinical efficacy - NIH-CPSI total score

\begin{tabular}{|c|c|c|c|c|c|c|c|}
\hline \multirow[t]{2}{*}{ Study or subgroup } & \multicolumn{2}{|c|}{ Prulifloxacin+supplements } & \multirow{2}{*}{$\begin{array}{r}\text { Prulifloxacin } \\
\mathrm{N}\end{array}$} & \multirow[b]{2}{*}{ Mean(SD) } & $\begin{array}{r}\text { Std. } \\
\text { Mean } \\
\text { Difference }\end{array}$ & \multirow[t]{2}{*}{ Weight } & \multirow{2}{*}{$\begin{array}{r}\text { Std. } \\
\text { Mean } \\
\text { Difference } \\
\text { IV,Random, } 95 \% \mathrm{Cl}\end{array}$} \\
\hline & $\mathrm{N}$ & Mean(SD) & & & IV,Random,95\% Cl & & \\
\hline \multicolumn{8}{|c|}{ I NIH-CPSI total score at the end of treatment } \\
\hline Cai 2009 & 106 & $1.96(2.2)$ & 37 & | $1.02(5.88)$ & + & $100.0 \%$ & $-2.56[-3.04,-2.08]$ \\
\hline Subtotal $(95 \% \mathrm{CI})$ & 106 & & 37 & & - & $100.0 \%$ & $-2.56[-3.04,-2.08]$ \\
\hline \multicolumn{8}{|c|}{ Heterogeneity: not applicable } \\
\hline \multicolumn{8}{|c|}{ Test for overall effect: $Z=\mid 0.44(P<0.0000 \mid)$} \\
\hline \multicolumn{8}{|c|}{$2 \mathrm{NIH}$-CPSI total score at follow-up (6 months) } \\
\hline Cai 2009 & 106 & $1.35(1.75)$ & 37 & |0.5| (3.72) & + & $100.0 \%$ & $-3.78[-4.36,-3.20]$ \\
\hline Subtotal $(95 \% \mathrm{CI})$ & 106 & & 37 & & $\bullet$ & $100.0 \%$ & $-3.78[-4.36,-3.20]$ \\
\hline \multicolumn{8}{|c|}{ Heterogeneity: not applicable } \\
\hline \multicolumn{8}{|c|}{ Test for overall effect: $Z=12.75(P<0.0000 I)$} \\
\hline
\end{tabular}


Analysis 22.2. Comparison 22 Fluoroquinolone plus herbal extracts or supplements versus fluoroquinolone: prulifloxacin plus supplements versus prulifloxacin, Outcome 2 Clinical efficacy - IPSS score.

Review: Antimicrobial therapy for chronic bacterial prostatitis

Comparison: 22 Fluoroquinolone plus herbal extracts or supplements versus fluoroquinolone: prulifloxacin plus supplements versus prulifloxacin

Outcome: 2 Clinical efficacy - IPSS score

\begin{tabular}{|c|c|c|c|c|c|c|c|}
\hline \multirow[t]{2}{*}{ Study or subgroup } & \multicolumn{2}{|c|}{ Prulifloxacin+supplements } & \multirow{2}{*}{$\begin{array}{r}\text { Prulifloxacin } \\
\mathrm{N}\end{array}$} & \multirow[b]{2}{*}{ Mean(SD) } & $\begin{array}{r}\text { Std. } \\
\text { Mean } \\
\text { Difference }\end{array}$ & \multirow[t]{2}{*}{ Weight } & \multirow{2}{*}{$\begin{array}{r}\text { Std } \\
\text { Mean } \\
\text { Difference } \\
\text { IV,Random,95\% C }\end{array}$} \\
\hline & $\mathrm{N}$ & Mean(SD) & & & IV,Random,95\% Cl & & \\
\hline \multicolumn{8}{|c|}{ I IPSS score at the end of treatment } \\
\hline Cai 2009 & 106 & $5.36(2.58)$ & 37 & $12.24(4.27)$ & + & $100.0 \%$ & $-2.21[-2.66,-1.75]$ \\
\hline Subtotal (95\% CI) & 106 & & 37 & & $\bullet$ & $100.0 \%$ & $-2.21[-2.66,-1.75]$ \\
\hline \multicolumn{8}{|c|}{ Heterogeneity: not applicable } \\
\hline \multicolumn{8}{|c|}{ Test for overall effect: $Z=9.50(P<0.0000 I)$} \\
\hline \multicolumn{8}{|l|}{2 IPSS score at follow-up } \\
\hline Cai 2009 & 106 & $4.63(2.29)$ & 37 & $11.72(3.98)$ & + & $100.0 \%$ & $-2.50[-2.98,-2.03]$ \\
\hline Subtotal (95\% CI) & 106 & & 37 & & $\bullet$ & $100.0 \%$ & $-2.50[-2.98,-2.03]$ \\
\hline \multicolumn{8}{|c|}{ Heterogeneity: not applicable } \\
\hline \multicolumn{8}{|c|}{ Test for overall effect: $Z=10.30(P<0.00001)$} \\
\hline & & & & -10 & -5 & 10 & \\
\hline
\end{tabular}




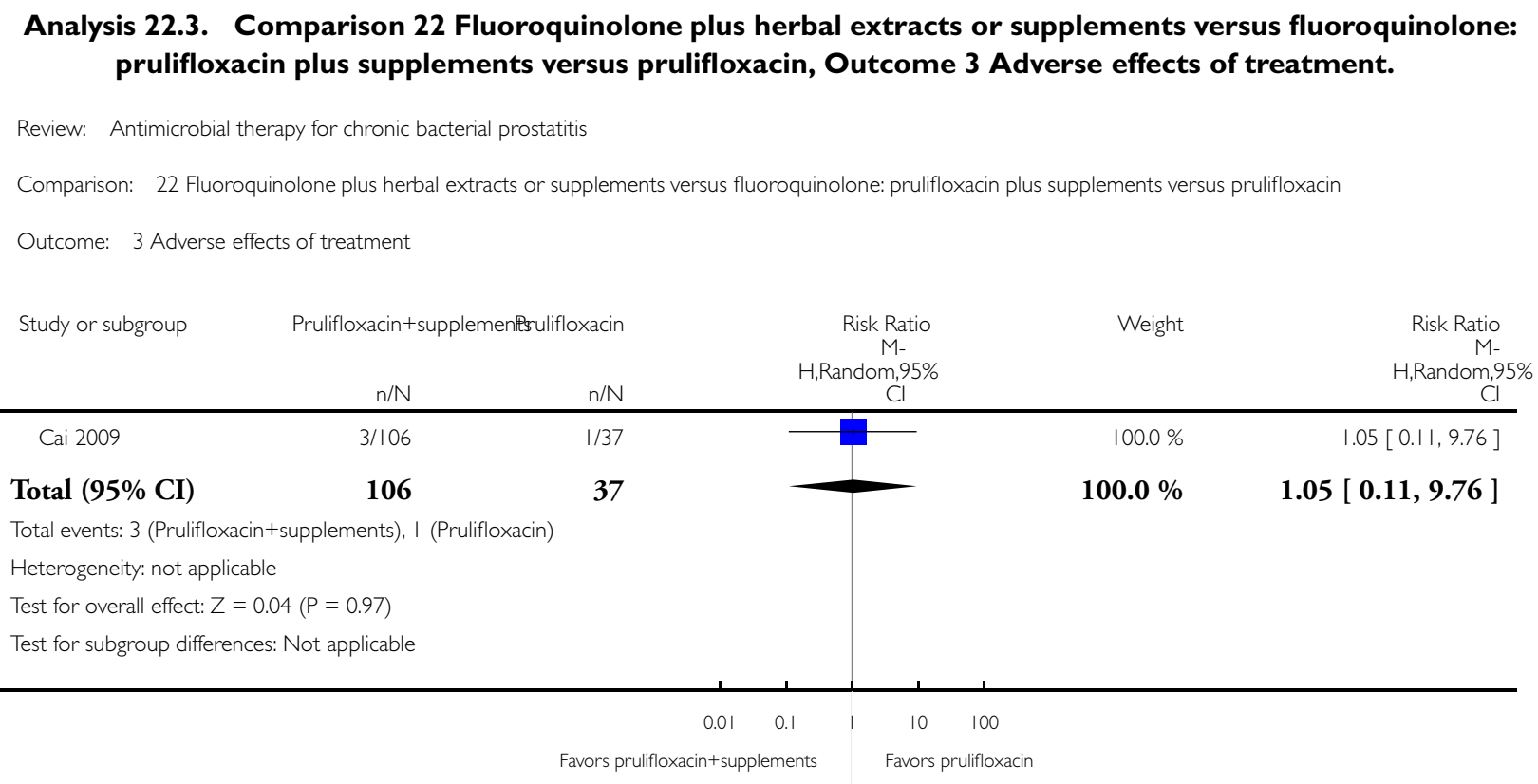

\section{CONTRIBUTIONS OF AUTHORS}

Conceiving, designing, coordinating and writing the review: GP

Undertaking searches: EM, GP

Screening search results: GP, EM

Screening retrieved papers against eligibility criteria: GP, EM

Appraising quality of papers: GP, VM

Extracting data from papers: GP, FMEW

Risk of bias assessment: GP, FMEW

Writing to authors of papers for additional information: EM

Screening data on unpublished studies: GP, FMEW

Data management for the review and entering data into RevMan: GP, EM

Analysis of data: GP, EM

Interpretation and discussion of data: FMEW, VM, GP

Providing a clinical perspective and general advice to the review: VM, FMEW 


\section{DECLARATIONSOF INTEREST}

Dr Perletti has been a consultant for Astellas Pharma Ltd and has received a research award and grant from the Prostatitis Foundation. Dr Marras has no known declarations of interest. Dr Wagenlehner has been a consultant for Astellas, AstraZeneca, OM-Pharma, Cernelle, Pierre Fabre, Lilly, and has received payment for lectures including service on speakers bureaus from Cernelle, OM-Pharma, Pierre Fabre, and Rosen Pharma; the disclosures did not influence the results of the manuscript. Dr Magri has been a consultant to Konpharma Srl.

\section{SOURCES OF SUPPORT}

\section{Internal sources}

- None, Not specified.

\section{External sources}

- The Prostatitis Foundation, USA.

Unrestricted Grant

\section{DIFFERENCES BETWEEN PROTOCOLANDREVIEW}

1. The order of the primary outcomes has been inverted. The first primary outcome is microbiological efficacy, whereas the second is clinical efficacy.

2. Studies in which a pool of different antibacterial agents were administered to participants within a single treatment arm were excluded if the effects of single antibiotics were not analyzed separately (subgroup analysis).

3. During the review process, the authors became aware of their lack of knowledge concerning traditional Chinese medicine. It was decided to exclude all studies involving traditional Chinese medications. Exclusion of such studies was performed either during title and abstract screening or during full article examination.

4. In the protocol, we proposed an imputation strategy as follows: "In case data were likely not missing at random, we considered what the event rates might have been in the missing data by imputing a range of possible outcome rates (including observed risk rates), as described in Chapter 16.2.2 of the Cochrane Handbook for Systematic Reviews of Interventions (Higgins 2009).” We subsequently decided to avoid imputation, and modified the Methods section as follows: "Because imputation strategies may significantly increase heterogeneity, we limited our analysis to participants for whom outcomes were obtained (available case analysis).”

\section{INDEX TERMS}

\section{Medical Subject Headings (MeSH)}

Anti-Bacterial Agents [*therapeutic use]; Bacterial Infections [ ${ }^{*}$ drug therapy; microbiology]; Chlamydia Infections [drug therapy]; Chronic Disease; Fluoroquinolones [*therapeutic use]; Macrolides [* therapeutic use]; Prostatitis [*drug therapy; microbiology]; Randomized Controlled Trials as Topic 


\section{MeSH check words}

Humans; Male 